\title{
Forest Succession and Wildlife Abundance Following Clear-cut Logging in West-Central Alberta
}

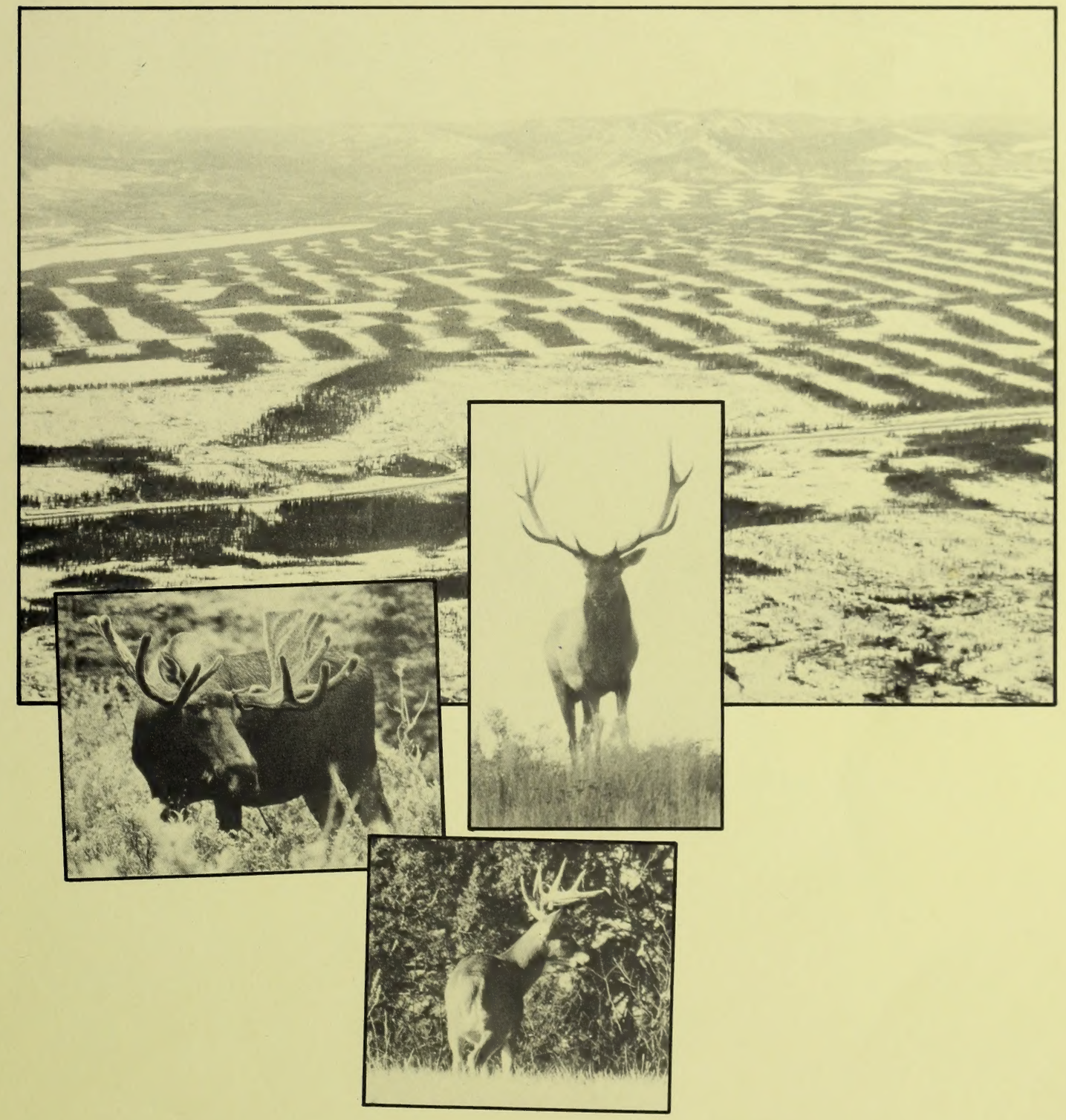

J.G. Stelfox

Wildlife Ecologist 15 December 1988 


\section{National Library
of Canada
du Canadiothue nationale}


FOREST SUCCESSION AND WILDLIFE ABUNDANCE FOLLOWING

CLEAR-CUT LOGGING IN WEST-CENTRAL ALBERTA

John G. Stelfox, Ph.D.

15 December 1988

Wildife Ecologist 
philadelphicum), asters, thin-leaved ragwort, and hedysarum.

At Year 26, big game use of forbs averaged $2.8 \%$ in mixedwood and $0.1 \%$ or less in spruce and pine clear-cuts. Comparable values for big game use of grasses were $<0.1 \%$ in mixedwood, $0 \%$ in spruce, and $0.1 \%$ in the pine clear-cuts. There was a significant difference $(p<0.01)$ in forb use among the three forest types, with pine treatments tending to be higher in scarified but lower in unscarified clear-cuts compared with the other two forests (Stelfox 1984).

At Year 32, big game use of forbs and grasses was similar to that recorded in Year 26.

4.3.3 Winter Forest/Wildlife Interactions - Security (hiding) and thermal cover was a greater determinant of habitat use of clear-cuts by deer, elk and moose than forage availability, as shown in earlier sections. Mature coniferous blocks, at least $100 \mathrm{~m}$ wide, were essential for winter thermal and security cover during the first 15-20 years following logging of the pine forest and the first 25 years following logging of spruce and mixedwood forests. Where these latter forests were scarified following logging, mature residual blocks interspersed throughout the clear-cuts were required for at least 30 years after initial logging.

There was a strong negative correlation $(r=-0.77)$ between wildife abundance and wind chill, indicating that winter residents avoid clear-cuts with poor shelter values (Fig. 15). Wildlife abundance represents the sum of all direct and indirect observations using an identical survey technique and time period for all blocks. (Stelfox 1984). There was also a negative correlation ( $r=-0.72$ ) between animal visibility and wildife abundance. The correlation between crown closure and wildlife abundance was strongly positive in spruce but less positive in pine and mixedwood clear-cuts.

At Year 26, winter wildife stocking rates were greatest in mixedwood treatments where they were twice as great as in spruce and 1.5 times greater than in pine treatments. Critical cover values of about $50 \%$ for each of security and coniferous canopy are needed before intensive yearlong use of clear-cuts by big game will occur (Fig. 15). The greatest diversity of animal species was in unscarified clear-cuts of all forests, then scarified clear-cuts, and lastly in mature blocks.

There was a positive correlation between abundance (winter 


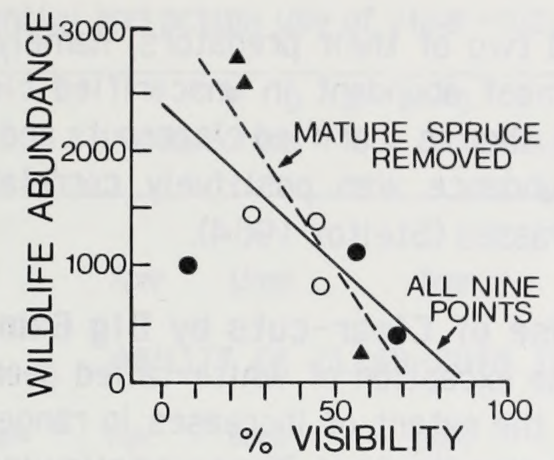

- WHITE SPRUCE

$\triangle$ MIXED WOOD

O LODGEPOLE PINE

y INTERCEPT $=2,291$

SLOPE $=-26.7$

$r=-0.72$

(ALL NINE POINTS)

y INTERCEPT $=3,325$

SLOPE $=-46.06$

$\begin{aligned} & r=-0.89 \\ & \text { (SPRUCE REMOVED) }\end{aligned}$

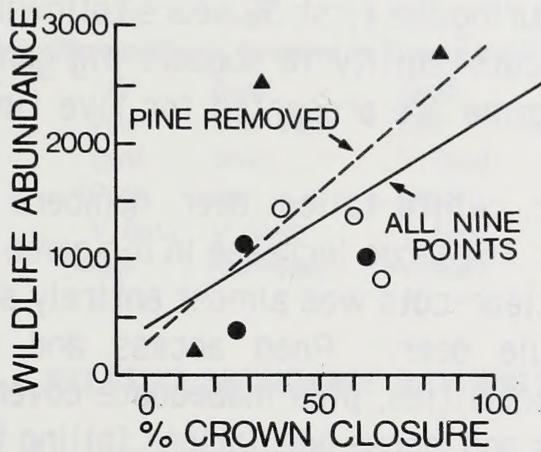

$y$ INTERCEPT $=443$

SLOPE $=22.6$ $r=0.63$

( $A L L$ NINE POINTS )

Y INTERCEPT $=253$

SLOPE $=25.9$

$r=0.65$

( PINE REMOVED )

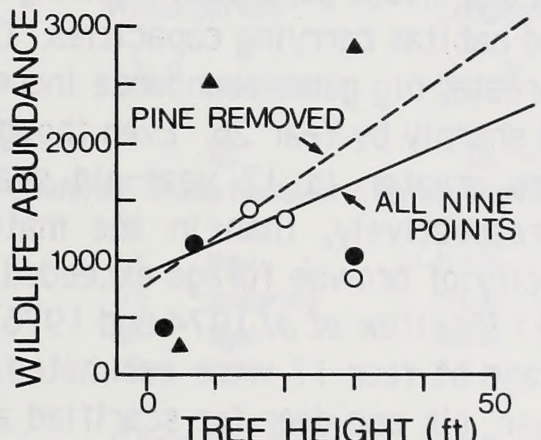

y INTERCEPT $=869$

SLOPE $=26.2$

$r=0.35$

( ALL NINE POINTS)

y INTERCEPT $=755$

SLOPE $=42.2$

$r=0.50$

(PINE REMOVED)

TREE HEIGHT $(\mathrm{ft})$

CONIFEROUS

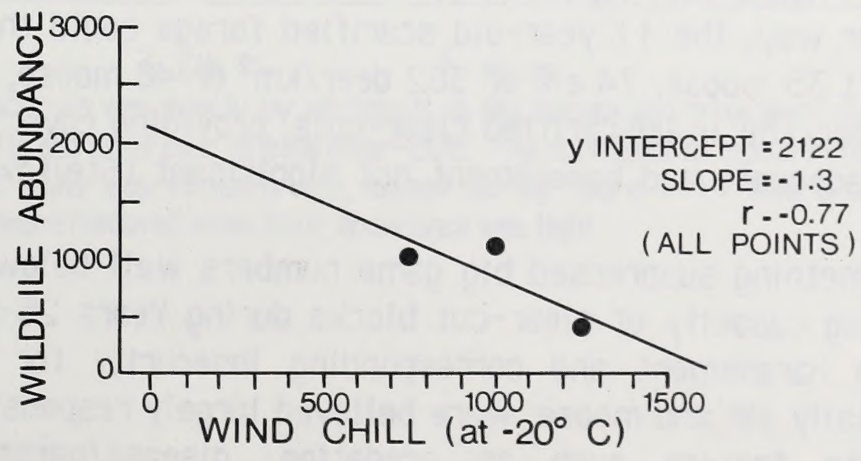

Figure 15. Correlations between winter wildlife abundance and security cover (\% visibility), conifer crown closure, conifer height and wind chill. 


\section{ABSTRACT}

Studies of forest succession, wildlife and habitat changes for a 32 year period following clear-cut logging were conducted in white spruce, lodgepole pine and mixedwood forests of west-central Alberta.

increases in biomass and diversity of grasses and forbs during the Grass-forb stage ( $1-10$ years) caused an increase in summer use by cervids, especially white-tailed deer and elk plus non-game species such as sparrows, thrushes, swallows, flycatchers and hawks compared to unharvested forests. Conversely, wildlife species of mature-old growth forest disappeared, especially in scarified clear-cuts. Spruce and ruffed grouse disappeared following logging while light use by sharp-tailed and blue grouse occurred. The presence of snags in unscarified clear-cuts resulted in the retention of snag-dwelling birds that were absent in scarified clear-cuts.

During the Shrub stage (11-20 years), cervid use was higher in clear-cuts, especially those unscarified, than in unlogged mature forests. A further increase was possible if residual blocks, interspersed among the clear-cuts had not been removed before adequate wildlife cover was available in the young clear-cuts. Adequate winter cover for cervids occurred 15-20 years post-logging in pine and 25-30 years in spruce and mixedwood clear-cuts. For scarified clear-cuts, this occurred at 15-20 years in pine and after 32 years in spruce and mixedwood clear-cuts.

Coniferous regeneration in spruce and mixedwood unscarified clear-cuts was advanced 5-10 years over scarified counterparts. Spruce seedlings, not destroyed in unscarified clear-cuts, had a major start over seedlings originating after scarification.

During the Pole sapling stage (15-25 years for mixedwood and pine, 20-40 years for spruce), improved wildlife habitat components (forage, thermal and security cover, nesting and brooding cover) resulted in increased abundance and species diversity of many non-game wildlife groups. Use by elk and moose declined whiledeer use increased. The former two species are more sensitive to human harassment than are deer. The abundance of five furbearer species (red squirrel, weasel, lynx, coyote, wolf) in mature forests was 3 and 17 times greater than in 26 year-old unscarified and scarified clear-cuts, respectively.

During the Immature stand stage (25-60 years), a rich diversity of wildife species existed in all clear-cuts, especially those unscarified. Bears were common in all clear-cuts $25-32$ years post-logging when there was an abundance of insect food in rotted stumps and logs. plus berries such as buffaloberries, and adequate escape cover.

A study of the role of native nitrogen-fixing plant species for wood fibre production and wildlife habitat and forage is recommended. Other recommendations are provided to assist land managers in developing forest-wildlife and timber harvesting plans. 
ABSTRACT.

TABLE OF CONTENTS.

Page

LIST OF TABLES.

LIST OF FIGURES

LIST OF APPENDICES.

ACKNOWLEDGEMENTS

1.0 INTRODUCTION

2.0 STUDY AREAS.

3.0 METHODS..

3.1 Harvest and Silvicultural Techniques.

3.2 Vegetation and Wildilfe Plots..

3.3 Photo Points.

3.4 Conifer Regeneration and Growth.

3.5 Habitat Quality.

3.6 Statistical Analyses.

4.0 RESULTS AND DISCUSSION..

4.1 Physiognomic Forest Changes.

4.2 Plant Density, Cover, Height and Species Richness..

4.2.1. Herbaceous Cover...

4.2.2 Species Diversity.

4.2.3 Deciduous Tree and Shrub Density.

4.2.4 Deciduous Tree and Shrub Height.

4.2.5 Coniferous Regeneration and Growth..

4.3 Habitat and Wildlife Abundance...

4.3.1 Cover and Big Game Use of Clear-cuts..

4.3.2 Forage Production and Use.

4.3.3 Winter Forest/Wildlife Interactions.

4.3.4. Potential and Actual Use of Clear-cuts By Big Game.

4.3.5 Upland Game-bird Trends.

4.3.6 Tree-cavity Dwelling Wildlife...

4.3.7 Avifauna General.

4.3.8 Furbearing Mammals and Prey Species.

5.0 SUMMARY AND CONCLUSIONS.

6.0 MANAGEMENT IMPLICATIONS.

7.0 RECOMMENDATIONS.

8.0 LITERATURE CITED.

9.0 APPENDICES. 
Table

1. Species richness in mature forests and various age-classes of scarified (SC) and unscarified (UN) clear-cuts.

2. Trends in coniferous (spruce and pine) densities (per ha)

3. Wildowing logging.

28

cuts based on pellet groups/hectare, 1988 .

4a. Browse forage production (green weight $\mathrm{kg} / \mathrm{ha}$ ) in clear-cut blocks following logging..

4b. Dry weight browse forage production $(\mathrm{kg} / \mathrm{ha})$ in clear-cut blocks following logging.

5. Potential and actual use of clear-cuts by big game.

6a. Density of snags, percent with cavities and percent being used by wildlife in three mixedwood forest blocks

6b. Wildlife species that will use tree snags of various diameters.

7. Snowshoe hare damage to 26 year-old pine trees correlated to coniferous and deciduous tree densities and heights. 


\section{LIST OF FIGURES}

Figure

1a. Diagram of sampling design within each of three forest types.......

1b. Diagram of sampling design and plot arrangement within each sample area.

2. Forest succession in white spruce following logging.

3. Forest succession in mixedwood clear-cuts following logging......

4a. Forest succession in an unscarified pine clear-cut following logging.

4b. Forest succession in lodgepole pine clear-cuts following logging.

5. Comparison of grass and forb cover between scarified and unscarified clear-cuts

6. Comparison of grass and forb cover following logging among three forest types.

7. Trends in follage cover of sedges and grasses following logging...

8. Trends in woody deciduous densities following logging...

9. Trends in densities of poplar and willow following logging.

10. Changes in heights of coniferous and deciduous trees and shrubs following logging.

11. Winter and summer thermal shelter for wild ungulates in 32 year-old clear-cuts and mature forests.

12. Summer visibility values for 5 heights above ground, averaged from spruce, pine and mixedwood forests for mature and 32 year-old clear-cuts.

13. Changes in big game abundance following logging

14. Preferred big game browse species, mountain ash and alpine fir, being suppressed in a 32 year-old lodgepole pine forest..

15. Correlations between winter wildlife abundance and security cover (\% visibility), conifer crown closure, conifer height and wind chill.

16. Gravel pit operations in scarified and unscarified mixedwood clear-cuts, 26-32 years after logging.

17. Furbearer abundance in mature and 26 year-old clear-cuts based on winter track counts.

18. Vitality of girdled pine trees less than and greater than 6 metres in height.

19. Girdling of 26 year-old pine by snowshoe hares (left) and damage by red squirrels (right). 


\section{LIST OF APPENDICES}

Appendix

Page

1. Field forms for recording 1988 forest-wildlife data.

2. Names and symbols of plant and animal species on forest/ wildlife plots: $1956-1988$

3. Statistical analyses of 1988 forest-wildlife data.

4. Foliage cover of grasses and forbs

5. Changes in density of woody plants following logging

6. Deciduous and coniferous heights in 32 year-old clearcuts within three forest types

7. Coniferous canopy cover and cervid visibility in 32 year-old clear-cuts.

8. Wildlife abundance (winter vs summer) following logging

9. Browse forage production in 32 year-old clear-cuts, 1988

10. Avifauna sightings in clear-cuts and mature forests.

11. Density of tree snags and use by wildlife

12. Glossary of terms 


\section{ACKNOWLEDGEMENTS}

Funding for the 1988 study was provided by Alberta Recreation, Parks and Wildlife Foundation; Weldwood of Canada Ltd., Hinton Division; Wildlife Habitat Canada; Alberta Fish and Game Association; and Alberta Fish and Wildlife Divison.

Three persons deserve special acknowledgement:

E. S. Huestis (late) - former Deputy Minister, Alberta Department Lands and Forests, who encouraged the initation of this study and who, as former Director of both the Alberta Forest Service and Fish and Wildlife, was a strong proponent of integrated forest/wildlife research and management;

J. D. Clark - former Woodlands Manager of Champion Forest Products (Alberta) Ltd. (CFPL) and its predecessors, who continually encouraged this study. As Rapporteur of the 1982 Forest/Wildlife Workshop in Jasper, on behalf of CFLP he proposed that the $7770 \mathrm{~km}^{2}$ lease area be used as a forest/wildlife management demonstration area;

D. I. Crossley (late) - former Chief Forester of CFPL's predecessor, St. Regis (Alberta) Ltd. who assisted in the selection and protection of study sites and whose unselfish advise and encouragement were important to the perpetuation of this study.

The cooperation of CFPL and its predecessors, especially that of Chief Foresters J. C. Wright and R. Udell, has been critical to the continuance of this study.

The Alberta Fish and Wildlife Division has supported and encouraged this study since its inception in 1956. The cooperation and assistance of regional wildilife biologists, K. G. Smith and G. M. Lynch are gratefully acknowledged.

The Alberta Forest Service, Canadian Wildlife Service and Canadian Forest Service, in Alberta, have provided advice and cooperation throughout the study. The Alberta Forest Technology School, Hinton has provided accommodation, laboratory and computer facilities.

I am grateful for field assistance and cooperation from R. G. H. Cormack, G. Kemp, J. B. Kemper, S. Lapointe, J. R. McGillis, D. J. Neave, H. W. Reynolds, D. G. Smith, E. S. Telfer and G. A. Wilde. I thank S. J. Barry, S. Popowich, L. Juba and R. B. Wilgus for help with preparation of the text and illustrations.

Special thanks are extended to R. U. Bonar, K. G. Smith, and J. B. Stelfox, for reviewing the report.

To my wife, Betty Stelfox, I am especially grateful for typing and proof reading the report. 



\section{I.0 INTRODUCTION}

A study was initiated in the foothills of west-central Alberta in 1956 to examine the impact of clear-cut logging on wildlife and their habitats within three forest types (white spruce, lodgepole pine, and mixedwood). Trends in wildlife numbers, coniferous regeneration, forage production, wildlife habitat ratings, and habitat preferences were compared among mature, logged/scarified, and logged/unscarified treatments in each forest type throughout a 32-year period. The main objectives of the study were:

(1) To determine if there were major differences in wildlife densities and habitats between areas scarified and those unscarified following clear-cut logging or between clear-cut and mature uncut blocks;

(2) To examine differences in wildlife abundance and habitat quality among clear-cut spruce, pine, and mixedwood cover types;

(3) To examine the relative importance of forest components in contributing to the three major wildlife habitat requirements namely food, shelter from inclement weather, and security (escape) cover. To determine the degree to which these three habitat requirements are met at various seral stages after logging;

(4) To compare levels of post-cut conifer regeneration between scarified and unscarified clear-cuts over time;

(5) To determine the effects of post-logging human activities on wildifie species.

Information on seasonal habitat requirements for wild ungulates in northern latitudes is scant. However, studies have shown that food supplies generally increase following logging, but that thermal and security cover is of ten lacking during early post-logging periods. For this reason cervids fail to exploit increased forage in young clear-cuts (Lyon and Jensen 1980, McNicol and Gilbert 1980). Winter thermal cover encompasses the variables of temperature, wind speed, precipitation and shade, and serves to maintain homeothermy and reduce energy expenditure of ungulates (Thomas 1979). In temperate regions, adequate winter thermal cover is provided by mature, dense-canopied conifer forests (Telfer 1974, 1978). Thomas (1979) defines minimal deer winter thermal cover as pole-sapling stage conifers with a canopy closure of $75 \%$. He states that elk require dense conifer stands at least $12.2 \mathrm{~m}$ (40 ft) in height with $75 \%$ canopy closure. Wind and 
precipitation penetration is reduced in proportion to tree height (Jeffrey 1970, Bergen 1971, Raynor 1971, Moen 1973, Berglund and Barney 1977). Larger tree crowns and denser canopies also intercept more solar energy (Miller 1964, Moen 1973). By moderating inclement weather, coniferous cover reduces metabolic rate (MR) of white-tailed deer by a factor of 2.0 and deciduous cover reduces MR by a factor of 0.5 (Stevens 1972). Thus coniferous cover is four times as effective as deciduous cover for energy maintenance.

Summer thermal cover is usually provided by deciduous and coniferous trees greater than $1.5 \mathrm{~m}$ in height with a canopy closure of at least 60\% (Thomas 1979). However, security is needed for concealment from predators, including man. Cervids will generally not venture far from security cover. Cover was expected to influence wildlife use of clear-cuts and the validity of this belief was examined during this study. Studies in the U. S. Northwest have shown that human harassment is largely responsible for the failure of elk to use suitable habitat (Lyon and Jensen 1980).

The reader is referred to the glossary (Appendix 12) for definitions of terms used in this report. 


\subsection{STUDY AREAS}

Studies were conducted in three boreal forest cover-types (spruce, mixedwood and pine) within the foothills of west-central Alberta near Hinton (53 latitude and $117^{\circ}$ longitude). Old (125-140 yr) white spruce (Picea glauca) and the mature (80-100 yr) mixedwood forests fall within the Boreal Mixedwood ecoregion of the Cordilleran region of Canada (Strong and Leggat 1981). The young-mature (60-70 yr) lodgepole pine (Pinus contorta) forest lies within the Boreal Foothills region.

The study areas have a continental subhumid climate, with long, cold winters modified by short periods of chinook (fohn wind) conditions and short, cool summers. Average annual precipitation is $330-390 \mathrm{~mm}$ at spruce and mixedwood forests (elevation $1000 \mathrm{~m}$ ) and $450 \mathrm{~mm}$ at the pine forest (elevation $1350 \mathrm{~m}$ ). Rainfall accounts for about $70 \%$ of precipitation and snowfall $30 \%$. Mean yearly temperature at Hinton (elevation $1000 \mathrm{~m}$ ) is $3.9^{\circ} \mathrm{C}$ while at the higher pine forest mean temperature is about $0^{\circ} \mathrm{C}$. The study area is generally snow covered from early November until mid/late April (Powell and Mclver 1976, Powell 1977, Hillman et al. 1978).

Soils of the study area have been described by Dumanski et al 1972, Corns and Annas 1983. Soll beneath the spruce forest is dominated by well drained Cumulic Regosols with Orthic Brunisols and Degraded Brunisols with a pH of 8.2 and good drainage. All horizons are weakly structured silt loams. The mixedwood soil is well drained and dominated by Orthic Gray Luvisols with Degraded Eutric Brunisols. The surface horizon is sandy loam and the subsurface a coarse, sandy clay loam with a pH of 6.6. Soll beneath the pine forest is dominated by Orthic Gray Luvisols with Brunisolic Gray Luvisols and good drainage. The clay/loam clay soll is friable and moderately stoney with a strongly acidic pH of 5.3 . This soll is overlain by a $0-2.5 \mathrm{~cm}$ layer of semi-decomposed litter

Understory vegetation of mature white spruce forests prior to logging resembled the shrub-herb faciation described by Moss (i953). The overstory was a dense stand of white spruce 30-40 $\mathrm{m}$ tall and $35-70 \mathrm{~cm}$ diameter at breast height ( $\mathrm{dbh})$, with a scattered distribution of mature balsam poplar (Populus balsamifera) in mesic sites. Sparse deciduous tree and shrub strata included willow (Salix spp.), dogwood (Cornus stolonifera), honeysuckle (Lonicera dioica and L. involucrata), low bush cranberry (Viburnum edule), buffalo-berry (Shepherdia 
canadensis), shrubby cinquefoil (Potentilla fruticosa), birch (Betula spp.), prickly rose (Rosa acicularis), ground and creeping juniper (Juniperus communis and $J$. horizontalis) and saskatoon (Amelanchier alnifolia). The herb strata was characterized by twin-flower ( Linnaez borealis), bunch-berry (Cornus canadensis), horsetail (Equisetum spp.), coltsfoot (Petasites spp.), northern bedstraw (Galium boreale) hedysarum (Hedysarum mackenzii and $H$. lanatum? tall mertensia (Mertensia paniculata), wintergreen (Pyrola spp.), miterwort (Mitella spp.), Solomon's seal (Smilacina spp.), baneberry (Actaea rubra) and club-moss ( $L$ ycopodium and Selaginella spp.). There was generally a floor carpet of mosses (Sphagnum and Dicranum spp.). The only graminoids of significance were hairy wildrye (Elymus innovatus) and sedges (Carex spp.) with small amounts of rushes (Juncus spp.), bromegrass (Bromus spp.), bluegrass (Poa spp.) and bluejoint (Calamagrostis canadensis).

Vegetation of the mature (80-100 yr) mixedwood forest seemed intermediate between Montane Forest and Poplar Associations (Moss 1955). White spruce dominated this community, though balsam poplar and lodgepole pine were common. Characteristic lesser tree and shrub species were aspen (Populus tremuloides), twining honeysuckle, buffalo-berry, prickly rose, snowberry (symphoricarpos albus), willow, common bearberry (Arctostaphylos uva-ursi) and saskatoon. The herb layer was characterized by wild strawberry (Fragaria vesca), northern bedstraw, Solomon's seal, American vetch (Vicia americana), milk vetches (Astragalus spp.), showy loco-weed (Oxytropis splendens), groundsels (Senecio spp.), tall mertensia, and fireweed (Epilobium. angustifolium). Graminoids were mainly hairy wildrye, bromegrass and blue joint.

The lodgepole pine association was a dense stand of young to mature pine with a sparse deciduous tree and shrub strata of a few clones of balsam and aspen poplar plus small amounts of green alder ( Alnus crispa), prickly rose, low-bush cranberry, willow, mountain ash (Sorbus scopulina), wild red raspberry (Rubus strigosis), wild gooseberry (Ribes oxyacanthoides), blueberries and bilberries (Vacciniumi spp.), honeysuckle and elderberry (Sambucus racemosa). The herb stratum consisted mainly of bunchberry ( Cornus canadensis), bedstraws (Galium spp.) horsetail, twin-flower, and palmate-leaved coltsfoot (Petasites palmatus) Two graminoids dominated, hairy wildrye and to a lesser extent bluejoint. There were traces of bluegrasses, sedges, 
timothy (Phleum pratense), wood rush (Luzula spp.), northern bent grass (Agrostis borealis)and slender wood grass (Cinna latifolia).

Major big game and fur-bearer species included moose (Alces alces), elk (wapiti) (Cervus elaphus), mule deer (Odocoileus hemionus), white-tailed deer ( 0 . virginianus), coyote (Canis latrans), wolf (Canis lupus), grizzly and black bear (Ursus arctos and $U$. americanus), lynx ( $L$ ynx canadensis), cougar (Felis concolor), red fox (Vulpes vulpes) mink (Mustela vison), ermine and least weasel (Mustela erminea and M. nivalis), marten and fisher (Martes americanaand M. pennanti), and red squirrel (Tamiasciurus hudsonicus). Estimated big game population densities prior to logging of the white spruce forest were 0.8 deer, 0.6 moose, 0.4 elk, 0.1 black bear, and $<0.1$ grizzly bear per $\mathrm{km}^{2}$ (Stelfox 1962). Snowshoe hare (Lepus americanus) and rodent (Clethrionomys, Phenacomys, Microtus spp.) populations experienced marked population fluctuations regardless of the forest age.

Common winter resident birds prior to logging were spruce grouse (Dendragopus canadensis), ruffed grouse (Bonasa umbellus), chickadee (Parus atricapillus and $P$. gambelli), pine siskin and common redpoll (Carduelis pinus and C. flammea), snow bunting (Plectrophenax nivalis), gray jay (Perisoreus canadensis), three-toed, hairy and downy woodpeckers (Picoides tridactylus, P. villosus, and P. pubescens), pine grosbeak (Pinicola enucleator), white-winged crossbill (LOxia leucoptera), Bohemian waxwing (Bombycilla garrulus), magpie (Pica pica), raven (Corvus corax), great horned owl (Bubo virginianus), boreal owl (Aegolius funereus), great gray owl (Strix nebulosa) and northern goshawk ( Accipiter gentilis). 


\subsection{METHODS}

\subsection{Harvest and Silvicultural Techniques}

The spruce forest was clear-cut into rectangular blocks $(201 \times 805$ $m$ ) at right angles to the prevailing westerly winds. One third of the mature forest, originally left as intervening blocks (101 $\times 805 \mathrm{~m})$ between clear-cuts, was removed $12-13$ years after the original harvesting. Less than $10 \%$ of clear-cut blocks were left unscarified.

One-half of the pine forest was scarified after an area of 283 ha was logged. For the mixedwood forest, residual blocks $(100 \times 100 \mathrm{~m})$ of mature timber were left interspersed throughout the clear-cut for the first 10-15 years after logging to serve as conifer seed sources. About one-half of the original clear-cut area was left unscarified.

Clear-cutting was accomplished by woodcutters using chain-saws, who cut and piled spruce and pine trees to be used for pulp wood. Logs were skidded to truck roads with horses. Scarification was achieved using large Caterpillar tractors (D7 and D9) equipped with rippers or rakers attached to the lower edge of the blade. Virtually all deciduous trees and shrubs were removed and the herb, grass and moss layers were mixed with the upper $25-50 \mathrm{~cm}$ of soil. For the pine clear-cut, scarification consisted of merely pushing down any standing pine snags and crushing the slash with Caterpillar tractors.

Unscarified blocks after logging retained standing snags and unmerchantable trees and shrubs. Soil disturbance was negligible and those blocks were not really "clear-cut" in the modern sense.

For all study areas, logging and scarification occurred during 1956 and 1957. Details on the silvicultural methods used during the 1950 s within the St. Regis (Alberta) lease area are provided by Clark (1960).

\subsection{Vegetation and Wildifife Plots}

The sampling design and terminology for this study are displayed in Fig. 1. Sample and plot sizes were originally (1950's) based on imperial units that were later converted to metric measures. Both measures are presented in this introductory section for the sake of clarification.

Two samples were established within each treatment (mature, scarified, and unscarified) for each of the three areas to encompass topographic and soll variability. Each sample was $54.9 \times 320.0 \mathrm{~m}$ (180 $\mathrm{x}$ $1050 \mathrm{ft}$ ) and randomly located a minimum distance of $30.48 \mathrm{~m}(100 \mathrm{ft})$ from the forest edge to eliminate edge effect. 


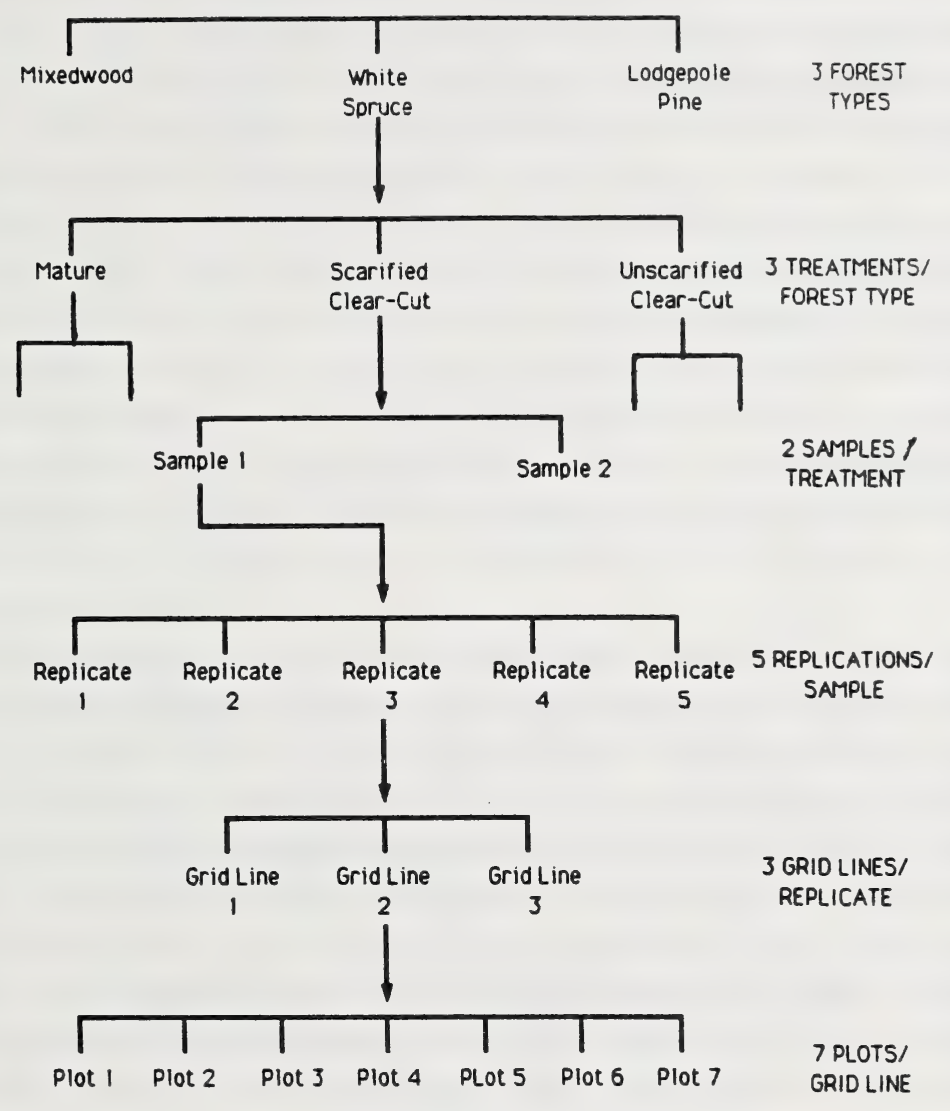

Figure 1a. Diagram of a sampling design within each of three forest types.

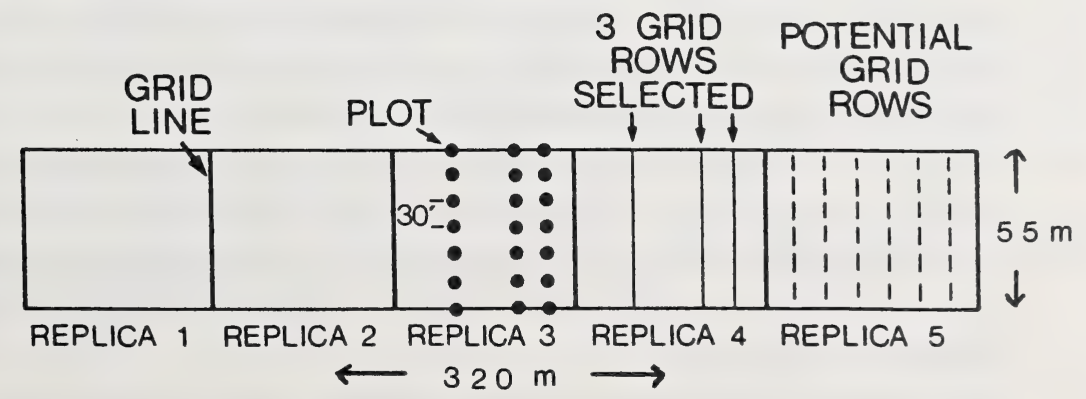

Figure ib. Diagram of a sampling design and plot arrangement within each sample area. 
Details of sampling methods, descriptions of angle point directions along transect axis, exact locations of samples and plots (including photoplots) and maps are provided in a separate operational report submitted to Alberta Fish and Wildlife Division, Edson of fice.

Each sample consisted of five replications, each containing six grid rows (from which three rows were randomly selected). Each of the 15 selected grid rows contained seven sample plots $\left(0.89 \mathrm{~m}^{2}\right.$ or $\left.9.6 \mathrm{ft}^{2}\right)$ spaced $9.14 \mathrm{~m}$ (30 ft) apart in a straight line (Fig. 1). Thus, each sample contained 105 plots, yielding 210 plots for each treatment (mature, scarified, and unscarified) in each forest type. Sampling intensity was chosen following a pilot study to determine the number of plots required to adequately sample browse heights, using the formula

$$
n=\frac{2 s^{2}}{0.10 \bar{x}}
$$

where " $\mathrm{S}$ " is standard deviation, " $\overline{\mathrm{x}}$ " is mean height, and 0.10 is the desired limit of the confidence interval expressed as a proportion of the mean (Stelfox 1963). A square plot frame, of $1 \mathrm{~cm}$ thick round rod, open on one side to facilitate placing it in brushy vegetation. was used to obtain foliage cover and tree density data. To increase accuracy in estimating foliage cover, a $0.09 \mathrm{~m}^{2}\left(1 \mathrm{ft}^{2}\right)$ plot frame, divided into sixteenths, was hand-held over each plant species. In 1988, the 105, $0.89 \mathrm{~m}^{2}$ plots were replaced by $100,1.0 \mathrm{~m}^{2}$ plots to conform with metric units. The first 100 of the previous 105 plot stakes were used and by increasing the plot size from $0.89 \mathrm{~m}^{2}$ to $1.0 \mathrm{~m}^{2}$ the area sampled actually increased from $93.4 \mathrm{~m}^{2}$ to $100.0 \mathrm{~m}^{2}$ per sample. Within each plot, data was collected on the following floral and faunal attributes:

a) Follage cover for grass and forb species, to the nearest $0.006 \mathrm{~m}^{2}$ until 1988 when it was to the nearest $0.01 \mathrm{~m}^{2}$;

b) Densities of deciduous and coniferous tree and shrubs;

c) Species composition for grass, forb, and browse vegetation groups;

d) Follage cover for each deciduous tree and shrub species was also obtained from clear-cut plots for Years 1 to 5;

e) Heights of browse plants were recorded to the nearest $1.25 \mathrm{~cm}$ until plants reached $2.44 \mathrm{~m}$ after which the height was estimated to the nearest $0.15 \mathrm{~m}$. In 1982 and 1988 , deciduous and coniferous tree and shrub heights were recorded under 12 height classes as shown in Appendix 1;

f) Big game utilization of plant species was recorded as either summer or winter use. Utilization classes were: $0 \%=$ none; $1-25 \%$ 
$=$ light; $26-50 \%=$ moderate; $51-75 \%=$ heavy; and $76-100 \%=$ very heavy. Percent use of total current years biomass was determined using the ocular-estimate-by-plot method (Pechanec and Pickford, 1937). For browse species this technique considers leaves and green stems up to a thickness of $0.75 \mathrm{~cm}$;

g) Utilization of browse species was also estimated from $20 \mathrm{clip}$ plots per sample. Browse refers to all deciduous or coniferous tree and shrub species observed to be eaten by wild ungulates. Browse species utilized by cervids are presented in Appendix 8. All live browse under $2.44 \mathrm{~m}$ in height was clipped. Clipped forage was placed in cotton bags and weights of both leaves and stems were recorded immediately. Forage was then air-dried to a constant weight. Browse forage production per unit area was then calculated (Appendix 9);

h) Big game, grouse and hare abundance was determined from fecal pellet group counts within a $9.3 \mathrm{~m}^{2}\left(100 \mathrm{ft}^{2}\right)$ circular plot. A $1.72 \mathrm{~m}$ rod served as the plot radius with permanent plot stakes serving as the center of the circle. For Years 17 and 26, pellet group counts were made from within the $0.89 \mathrm{~m}^{2}$ plots. During 1988, pellet group counts were made within $10 \mathrm{~m}^{2}$ or 25 $\mathrm{m}^{2}$ circular plots.

After each regular survey, a thorough investigation was made of the entire treatment and all direct and indirect observations of wildlife were recorded. As the same amount of time was spent in each of the study blocks, the results were considered comparable.

During Years 1-6, 9, 17, and 27, at least two winter track counts were conducted after fresh snowfall and all sets of tracks recorded by species, probable age, and sex classes (young of the year, adult, and large males). Direct wildlife observations were made using aerial (helicopter) and ground (drive and track) counts (Stelfox 1984).

Scientific and common names in this report conform to flora of Alberta (Moss 1983) for plants, The Mammals of Canada (Banfield 1977) for mammals, and American Ornithologists' Union (1983) for birds. See Appendix 2 for complete lists.

Results during the 1950's and 1960's were presented earlier (Stelfox and Cormack 1962, Stelfox et al 1973). 


\subsection{Photo Points}

Photo points were established in 1957 to monitor gross floral changes over time in scarified and unscarified clear-cuts. Black and white photographs were taken by placing a $35 \mathrm{~mm}$ (single reflex) camera on top of a $1.5 \mathrm{~m}$ high metal stake and centering the photo on a conspicuous permanent feature.

\subsection{Conifer Regeneration and Growth}

Conifer stocking rates (\% of plots occupied), density and height data for regenerating spruce and pine were obtained from 210 plots per treatment until 1988 when this was reduced to 200 plots because of the larger plot size $\left(1 \mathrm{~m}^{2}\right)$. Spatial distribution, height, and wildlife damage of the nearest conifer to each of the first 200 plot stakes were recorded for the spruce forest during Years 9, 17, 26 and 32 and for the other two forest types during Years 26 and 32.

\subsection{Habitat Quality}

Measures of seasonal habitat quality (security and thermal cover) were obtained by three techniques:

a) Wind chill was determined in mid-winter with a thermometer, and a hand-held anemometer at chest height $(1.2 \mathrm{~m})$. Ten wind velocity readings were taken, each for a duration of one minute, and the average of ten readings used as a measure of average wind velocity. Wind chill factors for each site were expressed in watts $/ \mathrm{m}^{2}$ (Canada Atmospheric Environment Service 1981). This information was obtained for the spruce forest type at Year 16 (January 1972) and Year 27 (January 1983).

b) Conifer canopy cover was determined for mature plus 25, 27 and 32 year-old clear-cuts (scarified and unscarified) for each forest type. This was achieved by estimating canopy diameter $(\mathrm{cm})$ of the first four conifers within each circular plots. Average canopy diameter was calculated and then the average tree canopy was determined using the formula: Area $=.7854 D^{2}$ where " $D$ " is the average canopy diameter. Tree area values were then multiplied by conifer density.

c) Security cover was estimated for mature, 27 and 32 year-old clear-cut blocks using a $0.3 \times 2.5 \mathrm{~m}$ vegetation profile board divided horizontally into five strata above ground level as follows: 
$1=\langle 0.5 \mathrm{~m} ; 2=0.5-1.0 \mathrm{~m} ; \quad 3=1.0-1.5 \mathrm{~m} ; 4=1.5-2.0 \mathrm{~m} ; 5=$ 2.0-2.5 m. The profile board was held vertically at a location $20 \mathrm{~m}$ due northwest of the plot stake. The percent of each segment that was visible was recorded. Observations were made at 30 locations within each sample. Visibility classes were coded as a percentage of the coloured rectangle: $\quad 1=0-20 \% ; 2=21-40 \% ; 3=41-60 \% ; 4$ $=61-80 \%$ (ave $=70 \%$ ); and $5=81-100 \%$.

Values for visibility (security cover) and thermal cover (windchill plus density, canopy closure, and height of conifers) were combined to evaluate many aspects of cover. Winter cover values were derived from percent canopy cover. Conifer canopy closure was determined by the Alberta Department of Energy and Natural Resources Inventory Section using standard photogrammetric forestry inventory procedures. Combined cover was determined as:

( $\Sigma$ canopy closure $+\%$ security cover).

2

d) Snags (dead or decadent) with diameters at least $15 \mathrm{~cm}$, diameter at breast height (dbh), were counted within the first 100 plots $(50$ $\mathrm{m}^{2}$ circular). Data were recorded on snag density, height, dbh, condition, presence and size of cavities, and presence of snag-dwelling wildlife. Snag condition classes were: sound, decadent, decayed.

\subsection{Statistical Analyses}

Analyses of mean plant height, density, cover, and utilization were conducted using 1-way or 2-way ANOVAs.

Differences in number of big game observations between treatments were analysed using the Wilcoxan signed rank test (Daniel 1978).

During 1988 statistical differences among the three forest types and the three treatments (mature, logged-scarified, logged-unscarified) were calculated using an MTS ANOVA analysis.

Computer tapes of all data recorded and analyses conducted have been submitted to Alberta Fish and Wildlife Division, Edson. 


\subsection{RESULTS AND DISCUSSION \\ 4.1 Physiognomic Forest Changes}

Clear-cut logging of mature forests produced open "Grass-forb" communities during the first 10 years (Figs. 2-4). This early successional community was interspersed with residual mature forest blocks in spruce and mixedwood clear-cuts until Years 12 and 13 when these residuals were removed. During Years 10-20, the "Shrubseedling" community was dominated by a conspicuous stand of poplar, willow and rose while grass cover declined. Young growth of pine became conspicuous in both pine clear-cuts by Year 15 (Fig. 4). During Years 20-32 the "Young growth" community in pine clear-cuts was dominated by rapidly growing pine, with strips of alder, poplar and willow along old logging roads (Fig. 4). Spruce and mixedwood clearcuts (unscarified) were dominated by a mixture of poplar, willow and spruce while in scarified clear-cuts conifers were not conspicuous (Figs. 2 and 3).

Blocks left unscarified in mixedwood and spruce clear-cuts contained many large poplar (including snags), young and dead spruce, and some willow (Figs. 2 and 3). Only a few pine snags remained in the unscarified pine clear-cut (Fig. 4). Some security (escape) cover remained for wild ungulates in unscarified spruce and mixedwood clear-cuts compared with little or none in scarified clear-cuts (Figs. 2-4). Desirable mosaics of open clear-cuts and mature forest (Thomas 1979, Stelfox 1984) were destroyed during Years 12 and 13 when mature residual blocks were removed within spruce and mixedwood forests.

A pronounced physiognomic change occurred in vegetation between Years 15 and 26 (Figs. 2-4). Within spruce and mixedwood forests, Shrub-sapling communities in scarified clear-cuts provided suitable cover and shelter during summer, but not winter. However, immature deciduous/coniferous trees in unscarified clear-cuts were, at Year 25, providing winter cover for wildlife. (Figs. 2-4).

Variability among plant density, height, percent cover and species richness was generally too great to show statistical differences ( $p<0.05$ ) between treatments, years, and forest types. However, trends over time were usually consistent, indicating that reported differences did exist but were not highly significant. 


\section{SCARIFIED}

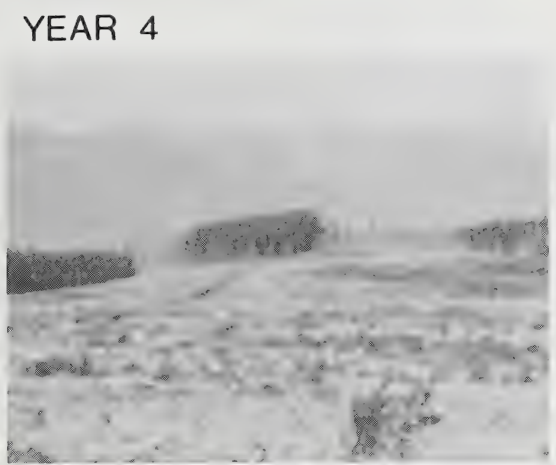

YEAR 16

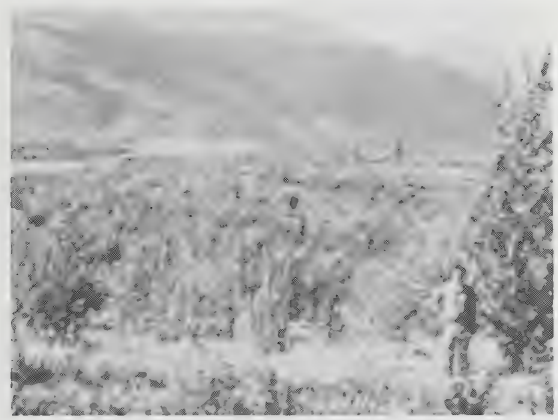

YEAR 25

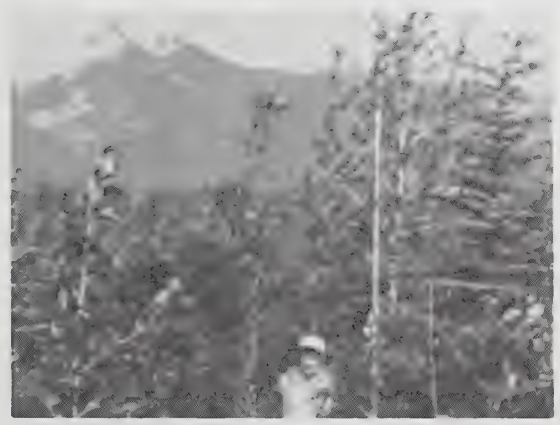

\section{UNSCARIFIED}

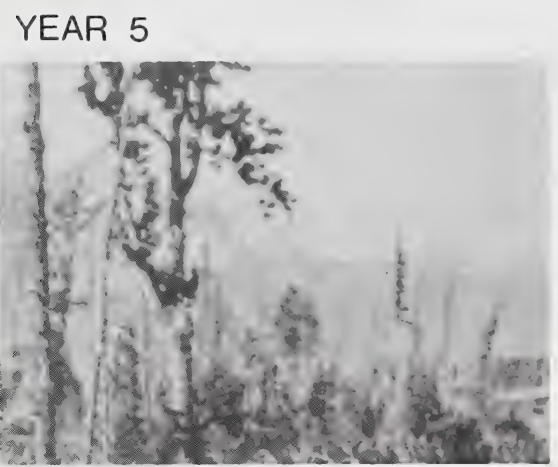

YEAR 16

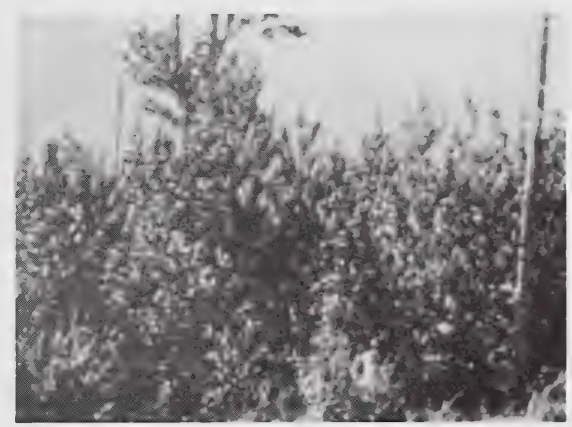

YEAR 25

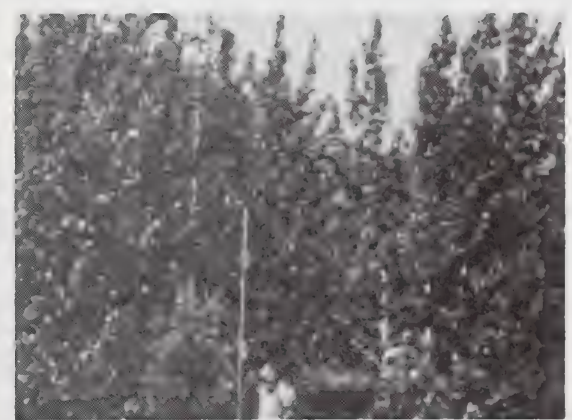

Figure 2. Forest succession in white spruce clear-cuts following logging. 
SCARIFIED

Year 1: August 1957

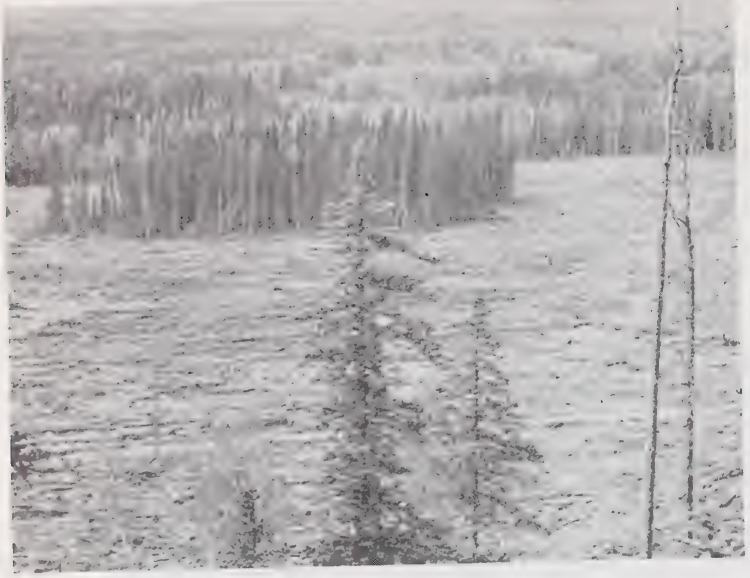

Year 16: August 1972

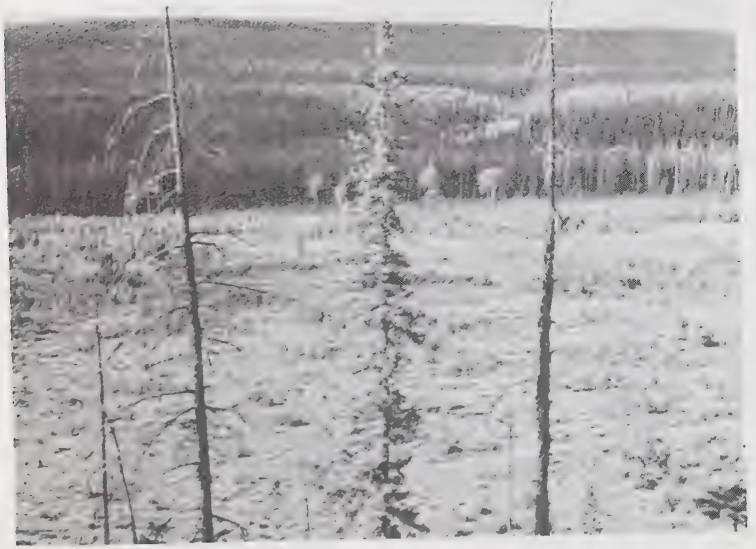

UNSCARIFIED

Year 3: December 1959

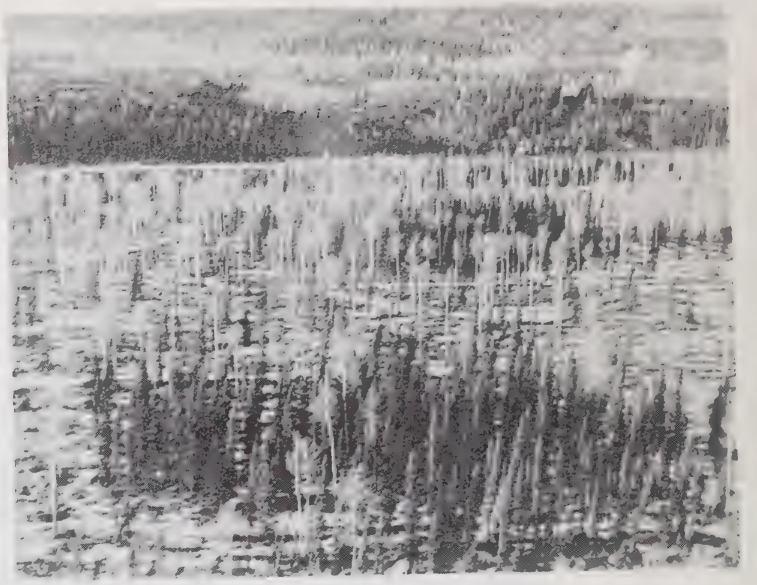

Year 16: August 1972

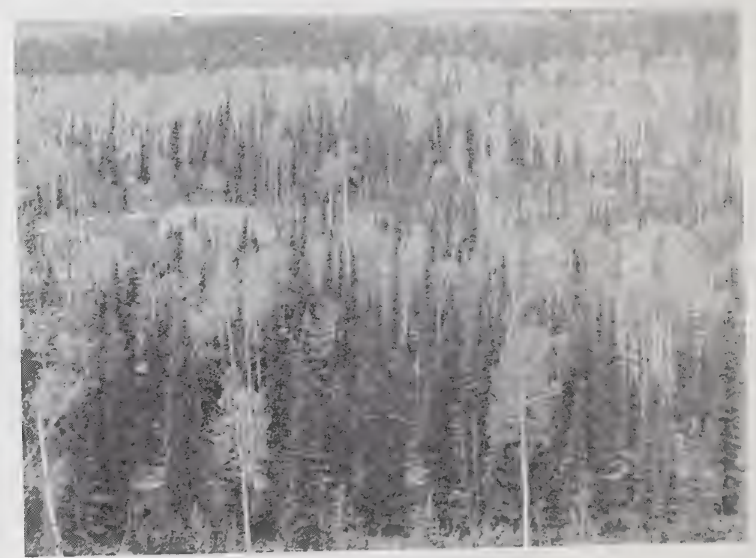

Year 32: July 1988 (Note gravel pit operation) Year 32: July 1988
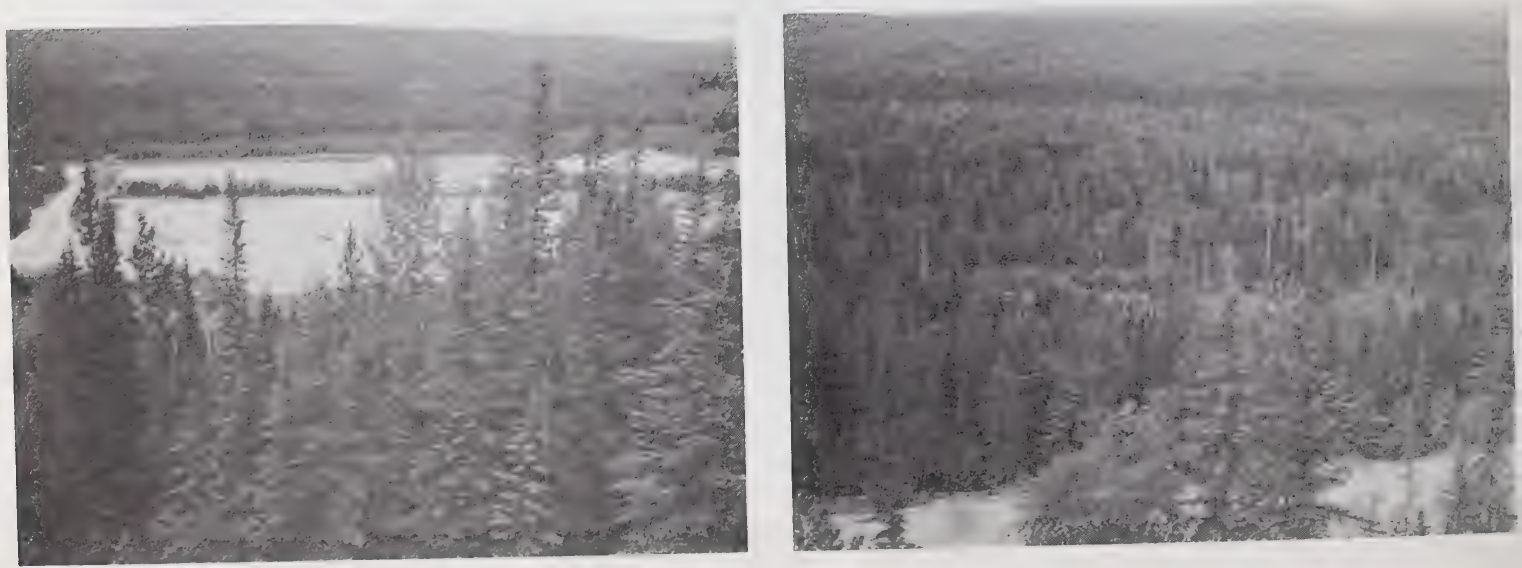

Figure 3. Forest succession in mixedwood clear-cuts following logging. 
Year 1: August 1957

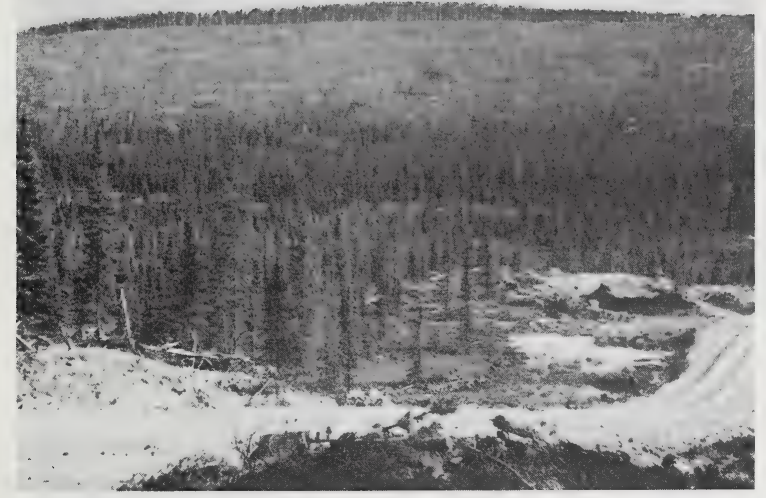

Year 16: August 1972

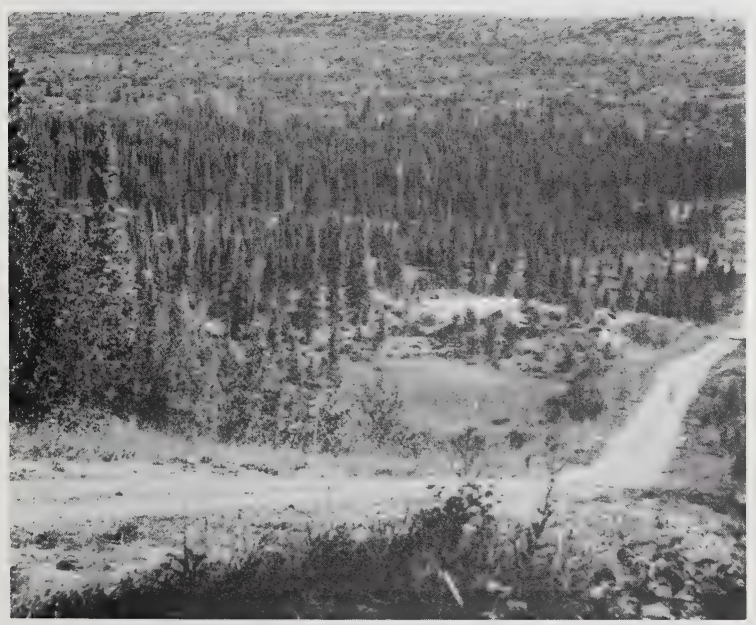

Year 9: August 1965

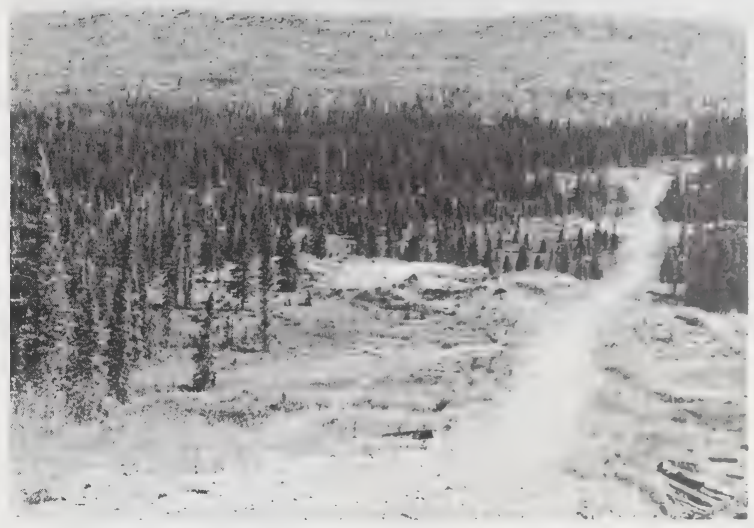

Yoar 32: July 1988

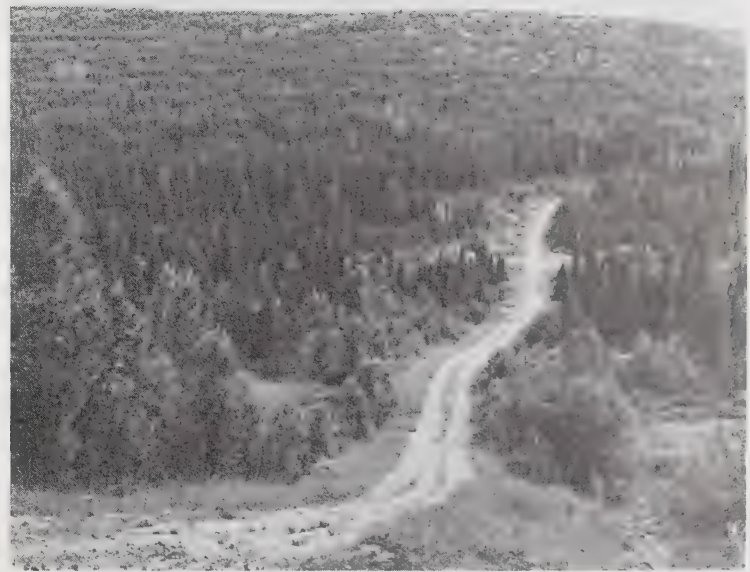

Figure 4a. Forest succession in an unscarified pine clear-cut following logging. 
SCARIFIED

Year 1: August 1957

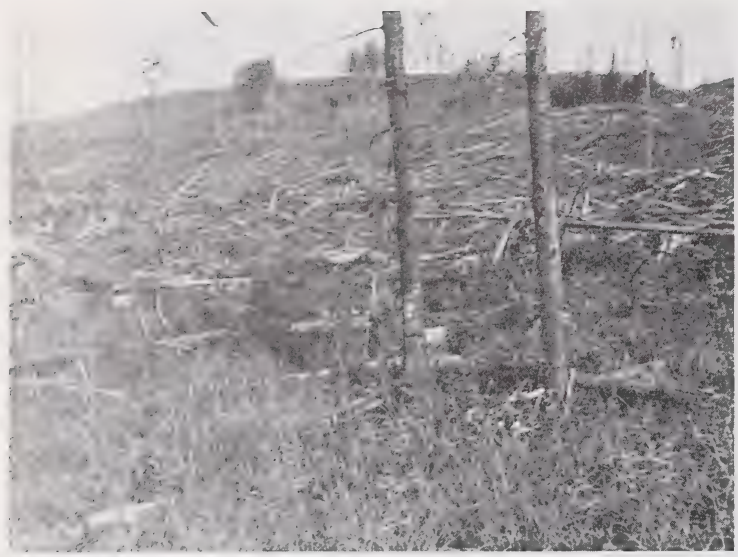

Yoar 16: August 1972

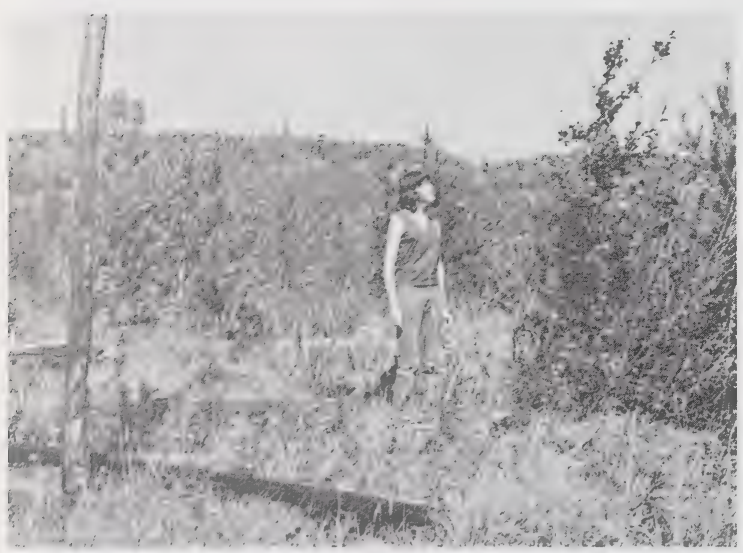

Year 32: July 1988

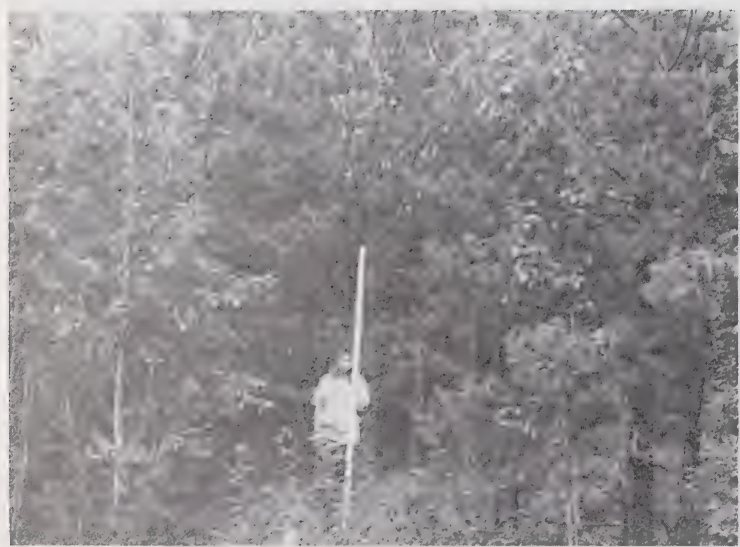

UNSCARIFIED

Vear 6: August 1962

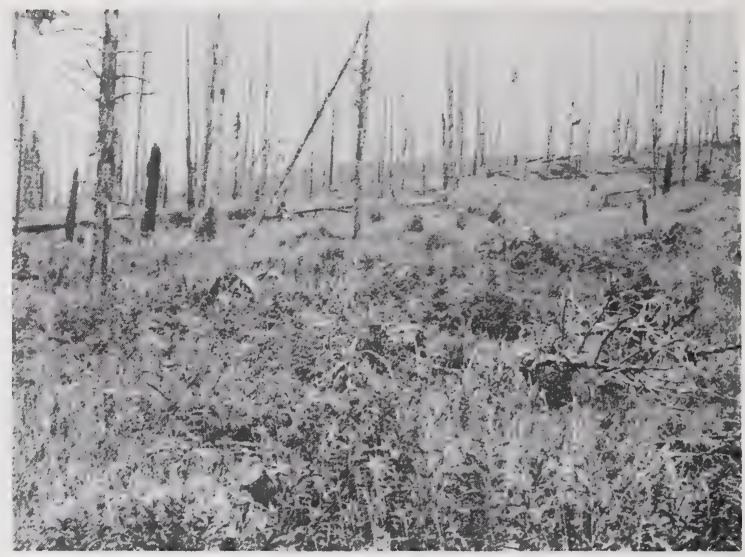

Yoar 25: August 1981

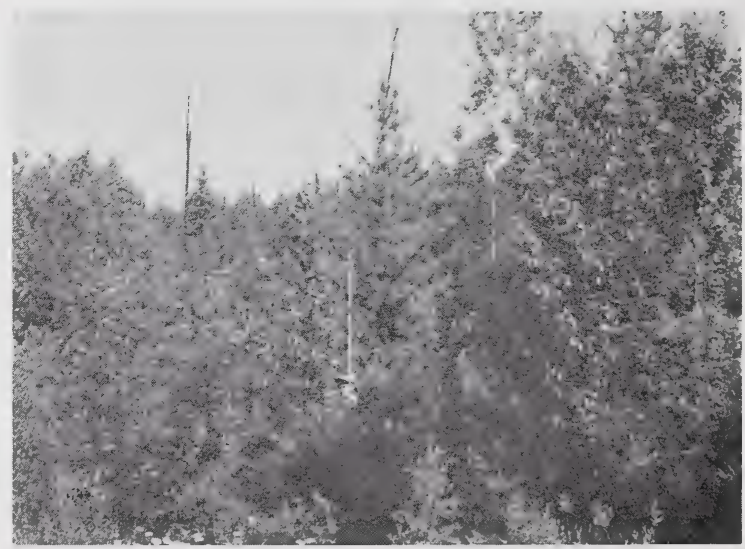

Year 32: July 1988

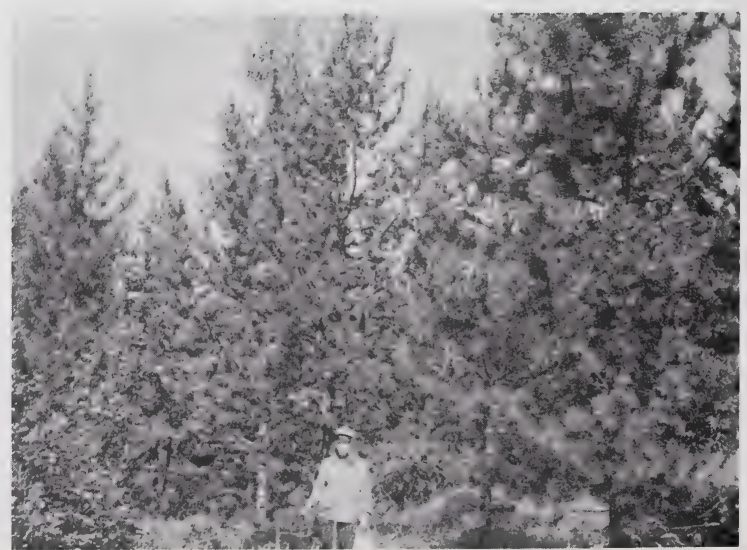

Figure 4b. Forest succession in lodgepole pine clear-cuts following logging. 


\subsection{Plant Density, Cover, Height, and Species Richness}

4.2.1. Herbaceous Cover - A major difference following clear-cut logging was the pronounced increase in foliage cover of both grasses and forbs during the first six years, followed by a decline to near pre-logging values by Year 26 (Figs. 5 and 6, Appendix 4). Cover values for grasses decreased from an average of $17 \%$ for mature forests to $15 \%$ one year after logging, then rose to $63 \%$ by Year 6 and declined to $22 \%$ and $19 \%$ at Years 26 and 32 . Scarification following logging further reduced grass cover to $8 \%$ one year after logging, followed by a rapid increase to an average of $54 \%$ by Year 6 and a decline to $23 \%$ and $18 \%$ at Years 26 and 32 . Although grass cover increases following logging were large in all three forests, they were greatest in pine, then spruce and least in mixedwood clear-cuts. By Year 32, grass cover values were only slightly higher than those in mature forests (Appendix 4). Changes in cover of native grass species, in particular major ones such as hairy wild rye, bromegrass, sedge, and reedgrass, are presented in Fig. 7, Appendices 3 and 4 . Introduced species that increased temporarily following logging and the use of horses included oats (Avena sativa and $A$. fatua), timothy, bluegrass and fescue (Festuca spp.).

No significant differences $(p<.05)$ existed in total grass cover of 32 year-old clear-cuts among the three forests, although two genera did show significant differences (Appendix 3). Bromegrass was common in mixedwood (5.1\%), less common in spruce (2.3\%) and almost absent in pine $(0.01 \%)$ clear-cuts. Reedgrass was abundant in pine $(8.7 \%)$, scarce in spruce $(0.2 \%)$ and absent in mixedwood forests.

Changes in forb cover followed the same trend as for grasses except that cover values were higher in scarified than in unscarified clear-cuts at Year 6 ( Figs. 5 and 6 , Appendix 4). In the spruce forest, forb cover declined from $16 \%$ prior to logging, to less than 5\% one year after logging, then peaked near Year 6 at about 25\% (Appendix 4). Forb cover was almost $50 \%$ lower in mixedwood than in spruce and pine clear-cuts at Year 6 (Fig. 6). At that time, forb cover in the three forests averaged $39 \%$ higher in scarified than in unscarified clear-cuts (Fig 5). During Years 26 and 32, values were similar in both clear-cut treatments ( Fig. 5. Appendix 4).

At Year 32, forb and mat-like low shrub cover averaged 26\% higher than grass cover and there were no significant differences 
WHITE SPRUCE

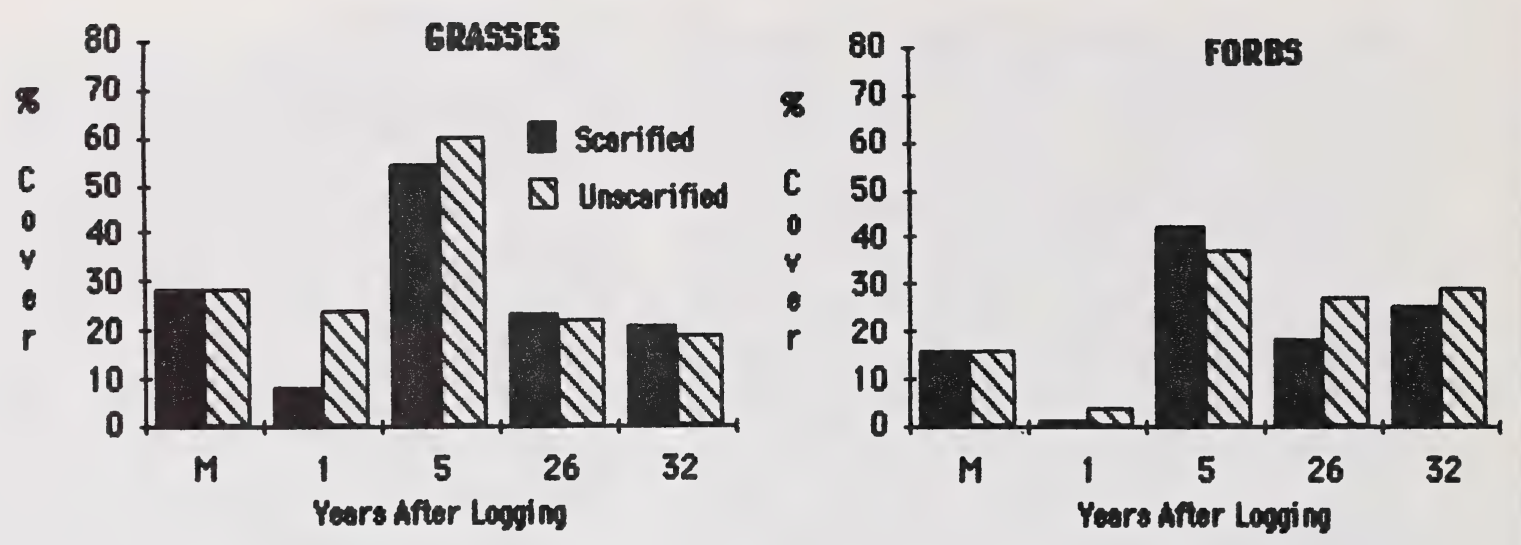

LODGEPOLE PINE
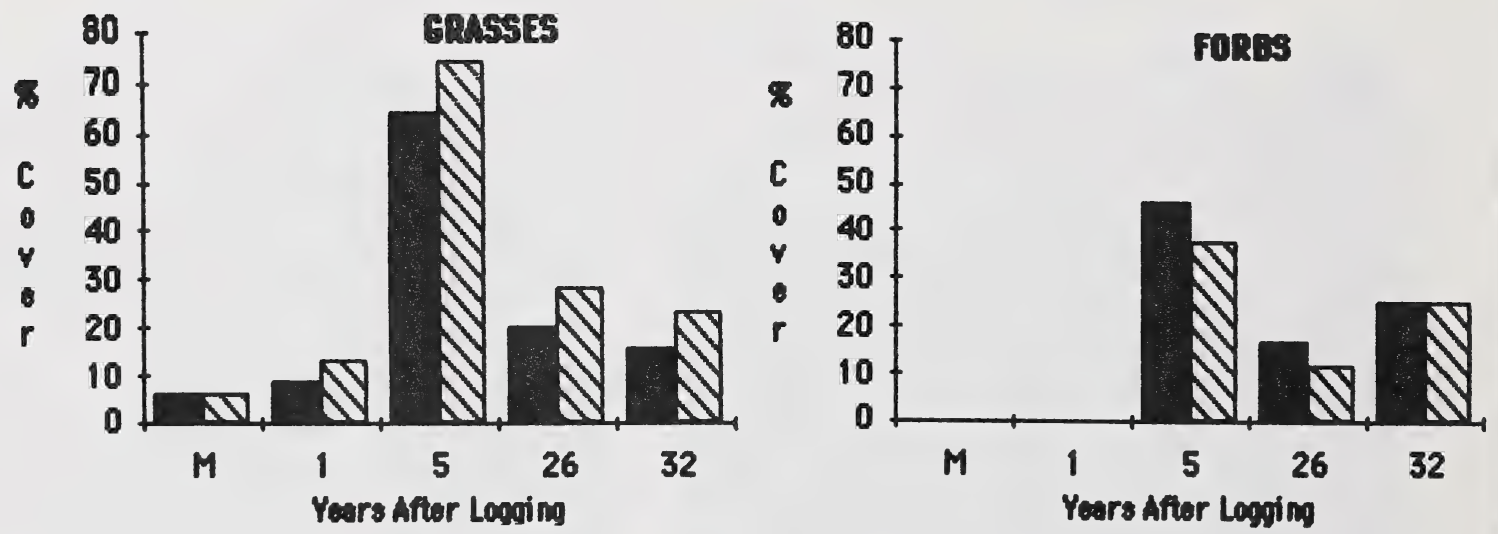

MIXEDWOOD
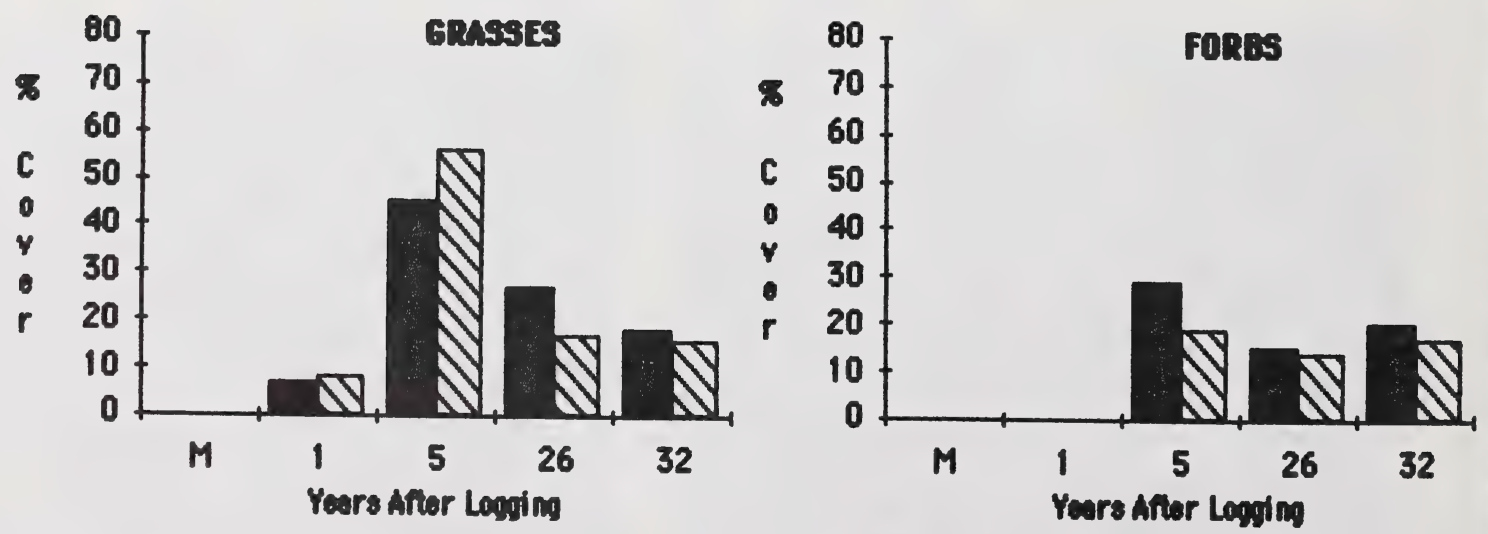

Figure 5. Comparison of gress and forb cover between scarified and unscarified cleer-cuts. 


\section{GRASSES}
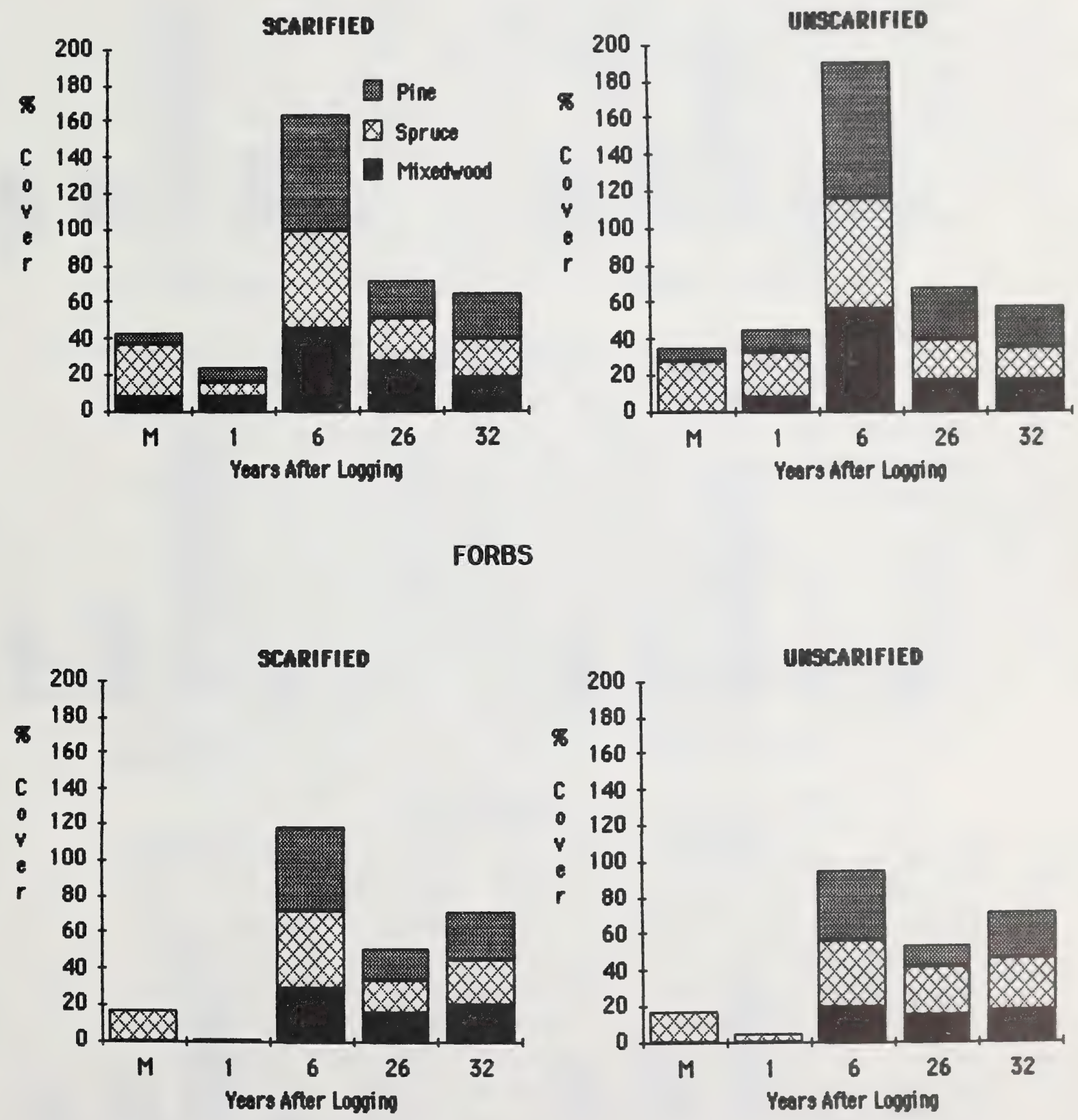

Figure 6. Comparison of grass and forb cover following logging among three forest types. 
WHITE SPRUCE

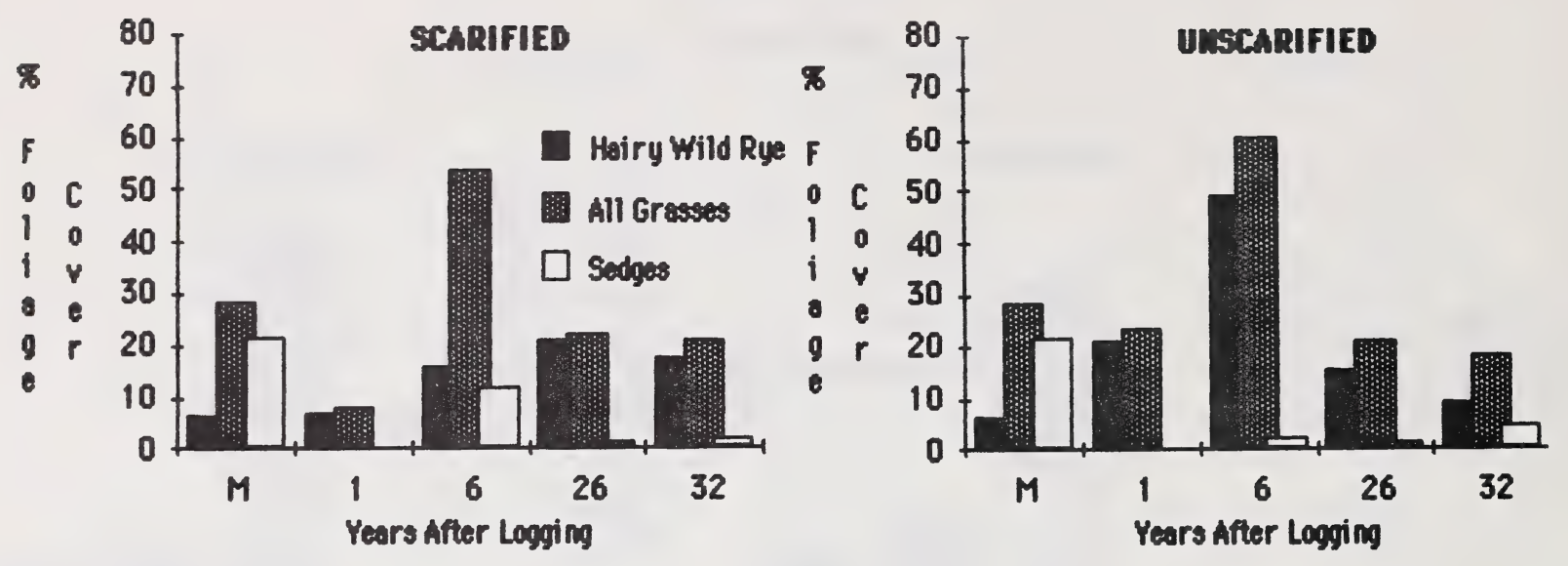

LODGEPOLE PINE
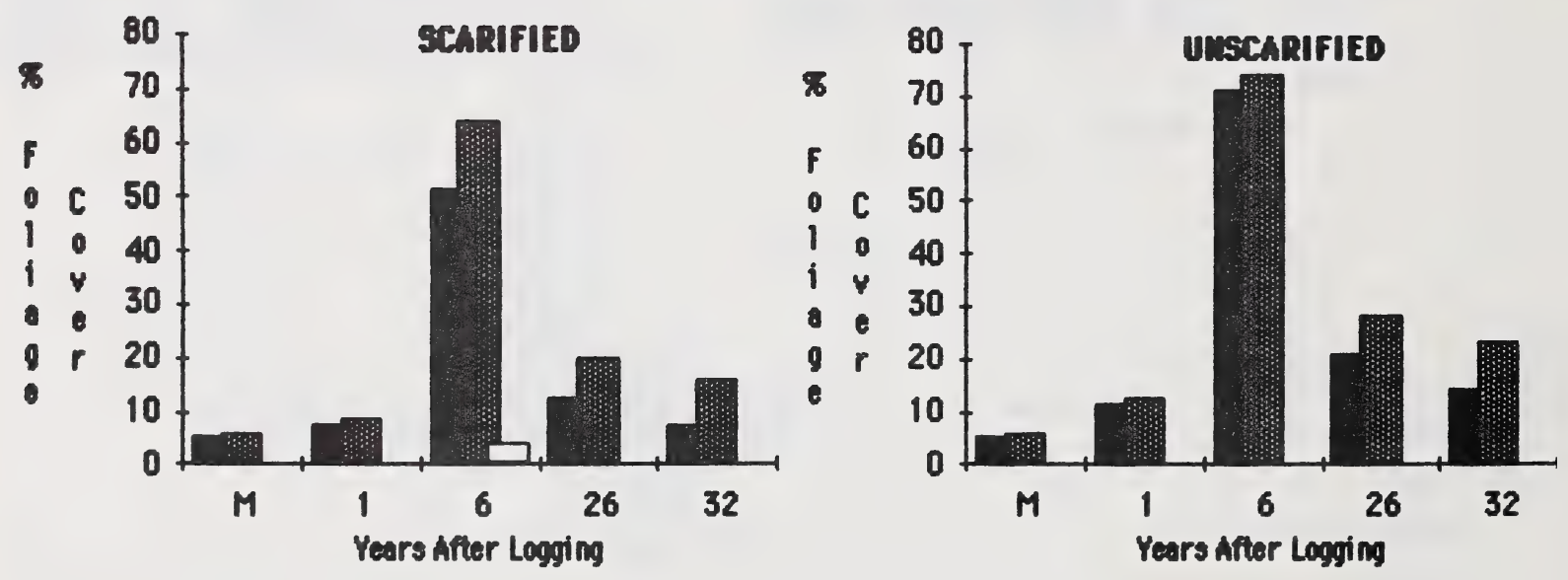

MIXEDWOOD
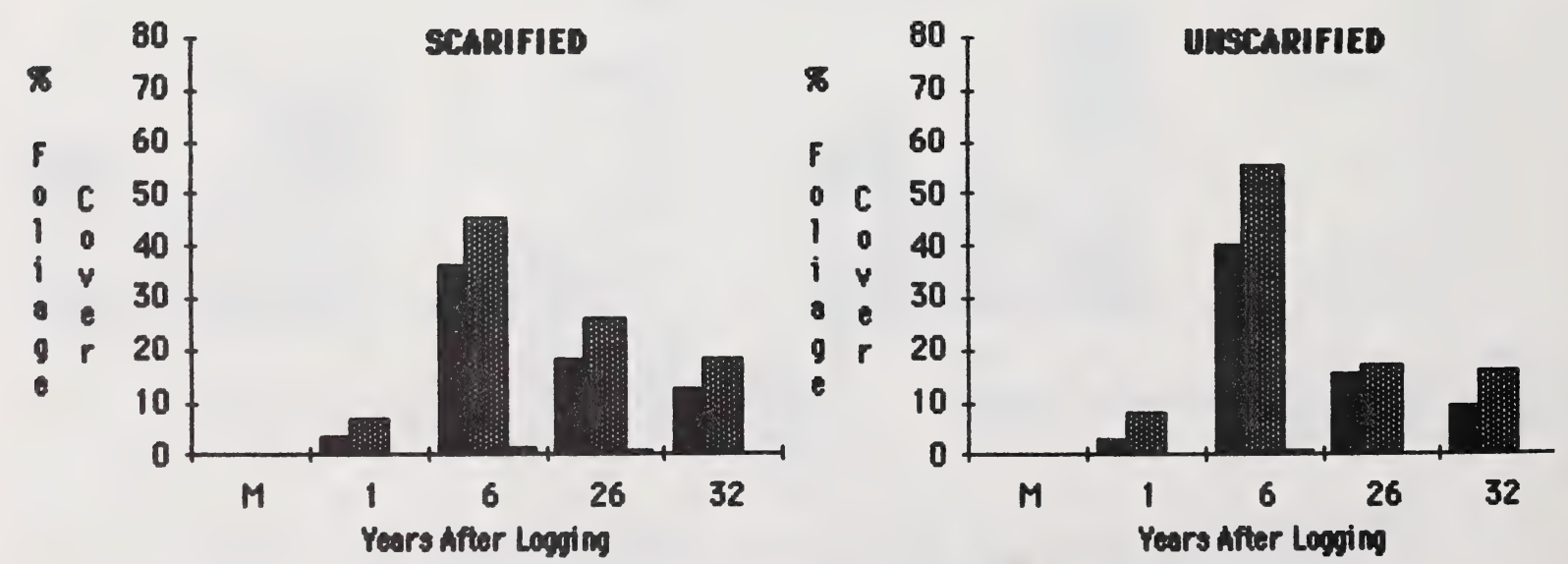

Figure 7. Trends in follage cover of sedges and grasses following logging. 
(p<.05) among forests (Appendix 3). However, some genera and groups of forbs were significantly different among forest types. Bearberry was highest in spruce (12.5\%), next in mixedwood (6.3\%) and least in pine $(0.2 \%)$ clear-cuts. Three nitrogen-fixing legumes: milkvetch, loco-weed, and Indian potatoe (Hedysarum spp.), had highest cover in spruce (3.1\%), next in mixedwood $(0.8 \%$ ) and none in pine clear-cuts. Two other nitrogen-fixing legumes: peavine (Lathyrus ochroleucus) and vetch were common in mixedwood (1.6\%), scarce in pine $(0.1 \%)$ and absent in spruce clear-cuts. Fireweed was significantly higher in pine $(8.0 \%)$ than in mixedwood (0.5\%) or spruce $(0.2 \%$ ) clear-cuts (Appendix 3 ).

4.2.2. Species Diversity - There was a pronounced increase in species diversity during the first 5 years following logging. At Year 5 in spruce clear-cuts, 26 forb species were recorded that were not found in the mature block (Stelfox 1963 and 1981). Aster (Aster spp.), Indian potatoe, groundsel, fleabane (Erigeron spp.), fireweed, tall mertensia, and white camas (Zygadenus elegans) comprised most of forb cover in spruce clear-cuts (Appendix 4). For the mature spruce forest they were northern bedstraw, Indian potatoe, asters, tall mertensia, and groundsels (Appendix 4, and Stelfox 1963). Forb species richness continued to increase to Year 26 at which time there were about twice as many forb species in spruce and mixedwood clear-cuts as in corresponding mature forests. At that time there were 30-40 forb species present in pine clear-cuts compared with only 4 in mature pine.

The number of grass species declined following logging in the spruce forest but not in pine and mixedwood forests. By Year 26, the number of grass species was similar in both logged and mature blocks of the spruce forest. Between Years 5 and 32, in pine and mixedwood forests, there were 2-5 times as many grass species in logged as in mature blocks. Following logging in the spruce forest, there was no discernable difference in grass species diversity between scarifled and mature blocks, but an increase in the number of grass species in unscarified blocks, during this same period.

There was a small increase in the number of grass and forb species present in spruce and pine clear-cuts between Years 26 and 32 while in mixedwood clear-cuts species diversity remained similar (Table 1). 
Table 1. Species richness in mature forests and various age-classes of scarified (SC) and unscarified (UN) clear-cuts.

\begin{tabular}{|c|c|c|c|c|c|c|c|c|}
\hline \multirow{3}{*}{$\begin{array}{l}\text { Forest } \\
\text { age }\end{array}$} & \multicolumn{8}{|c|}{ Number of Species } \\
\hline & \multicolumn{2}{|c|}{ Browse } & \multicolumn{2}{|c|}{ Forbs } & \multicolumn{2}{|c|}{ Grasses } & \multicolumn{2}{|c|}{ Total } \\
\hline & SC & UN & SC & UN & SC & UN & SC & UN \\
\hline \multicolumn{9}{|c|}{ WHITE SPRUCE FOREST } \\
\hline Mature & \multicolumn{2}{|c|}{15} & \multicolumn{2}{|c|}{28} & \multicolumn{2}{|c|}{13} & \multicolumn{2}{|c|}{56} \\
\hline 1 & 9 & 10 & 9 & 12 & 5 & 7 & 23 & 20 \\
\hline 5 & 5 & 7 & 25 & 26 & 11 & 7 & 41 & 29 \\
\hline 26 & 13 & 12 & 53 & 50 & 8 & 12 & 74 & 74 \\
\hline 32 & 10 & 9 & 58 & 59 & 10 & 13 & 78 & 81 \\
\hline \multicolumn{9}{|c|}{ LODGEPOLE PINE FOREST } \\
\hline Mature & \multicolumn{2}{|c|}{13} & 2 & & \multicolumn{2}{|c|}{2} & \multicolumn{2}{|c|}{19} \\
\hline 1 & 5 & 5 & 5 & 6 & 2 & 2 & 12 & 13 \\
\hline 5 & 11 & 10 & 20 & 21 & 11 & 9 & 42 & 40 \\
\hline 26 & 14 & 15 & 38 & 31 & 7 & 7 & 59 & 53 \\
\hline 32 & 12 & 11 & 40 & 34 & 9 & 8 & 61 & 53 \\
\hline \multicolumn{9}{|c|}{ MIXEDWOOD FOREST } \\
\hline Mature & \multicolumn{2}{|c|}{9} & & 7 & \multicolumn{2}{|c|}{4} & \multicolumn{2}{|c|}{30} \\
\hline 1 & 9 & 9 & - & - & 3 & 2 & & - \\
\hline 5 & 9 & 9 & 16 & 17 & 8 & 4 & 33 & 30 \\
\hline 26 & 10 & 10 & 37 & 39 & 10 & 10 & 57 & 59 \\
\hline 32 & 7 & 8 & 37 & 39 & 10 & 8 & 54 & 55 \\
\hline \multicolumn{9}{|c|}{ THREE FORESTS (AVES.) } \\
\hline Mature & \multicolumn{2}{|c|}{12} & 1 & & \multicolumn{2}{|c|}{6} & \multicolumn{2}{|c|}{34} \\
\hline 1 & 8 & 8 & - & - & 3 & 4 & - & \\
\hline 5 & 8 & 9 & 20 & 21 & 10 & 7 & 38 & 37 \\
\hline 26 & 12 & 12 & 43 & 40 & 8 & 10 & 63 & 62 \\
\hline 32 & - & - & 45 & 44 & 10 & 10 & 64 & 63 \\
\hline
\end{tabular}


Numbers of woody browse species declined following logging in spruce and pine forests (Table 1). By Years 26 and 32, species diversity was similar in clear-cuts and their corresponding mature forests.

4.2.3 Deciduous Tree and Shrub Density - For all forest types, the trend was a decrease in density following logging/scarification (Fig. 8). For spruce and mixedwood forests, logging/scarification reduced the density of deciduous trees and shrubs by $43 \%$. In pine clear-cuts, where scarification merely involved leveling unmerchantable trees and trampling slash with caterpillar tractors, density of deciduous trees and shrubs was not reduced. One year after logging, densities in scarified clear-cuts were $60 \%$ lower than in unscarified clear-cuts for all forest types. At Year 6 , scarified clear-cuts were $15 \%$ lower than unscarified clear-cuts while at Year 26, densities were similar in both clear-cuts. At Year 32, scarified clear-cut densities averaged $10 \%$ lower than those in the unscarified clear-cuts (Fig. 8, Appendix 5). Densities appeared to peak at about Year 17 in spruce clear-cuts and to be still increasing in pine and mixedwood clear-cuts at Year 32 (Fig. 8).

Prickly rose increased 4 to 7 fold between Year 1 and Years 17-32 when it peaked. Average densities following logging were similar in scarified and unscarified clear-cuts of pine and mixedwood forests but noticeably higher in unscarified than in scarified spruce clear-cuts.

Poplar and willow densities peaked near Year 9 in scarified clear-cuts of the spruce forest and about Years 26-32 in the other two forest types (Fig. 9). Results for unscarified clear-cuts are less clear but suggest that both poplar and willow peaked about Year 9. Densities of poplar and willow were significantly higher in spruce than in pine and mixedwood clear-cuts throughout the 32 year period following logging (Appendix 5). Changes in species densities are presented in Figs. 8 and 9, Appendices 3 and 5 .

Another deciduous woody species that changed noticeably in the pine forest following logging was green alder (Alnus crispa) Increases were somewhat higher in the scarified clear-cut during Years 26 and 32 (Appendix 5). This species was not present in spruce and mixedwood forests. This is an important species to consider in forest-wildlife management of pine forests because of its nitrogen-fixing capability. Studies in North America and 
WHITE SPRUCE
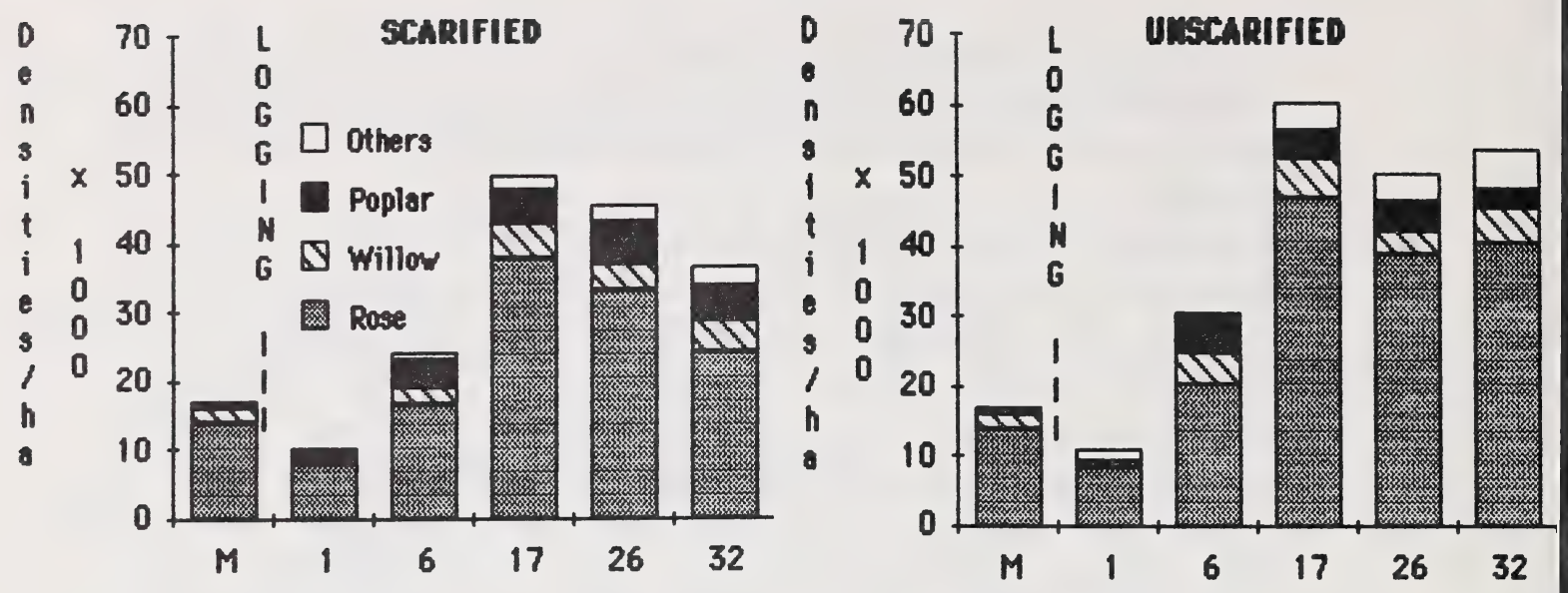

\section{LODGEPOLE PINE}
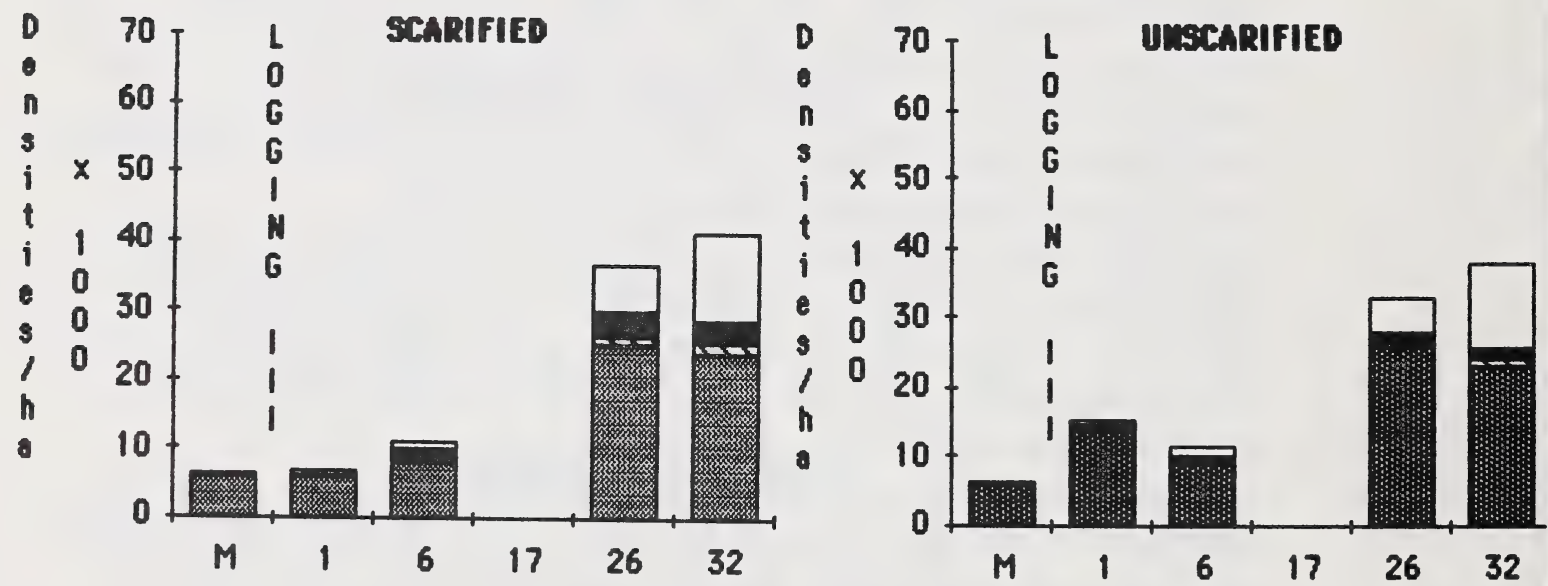

\section{MIXEDWOOD}
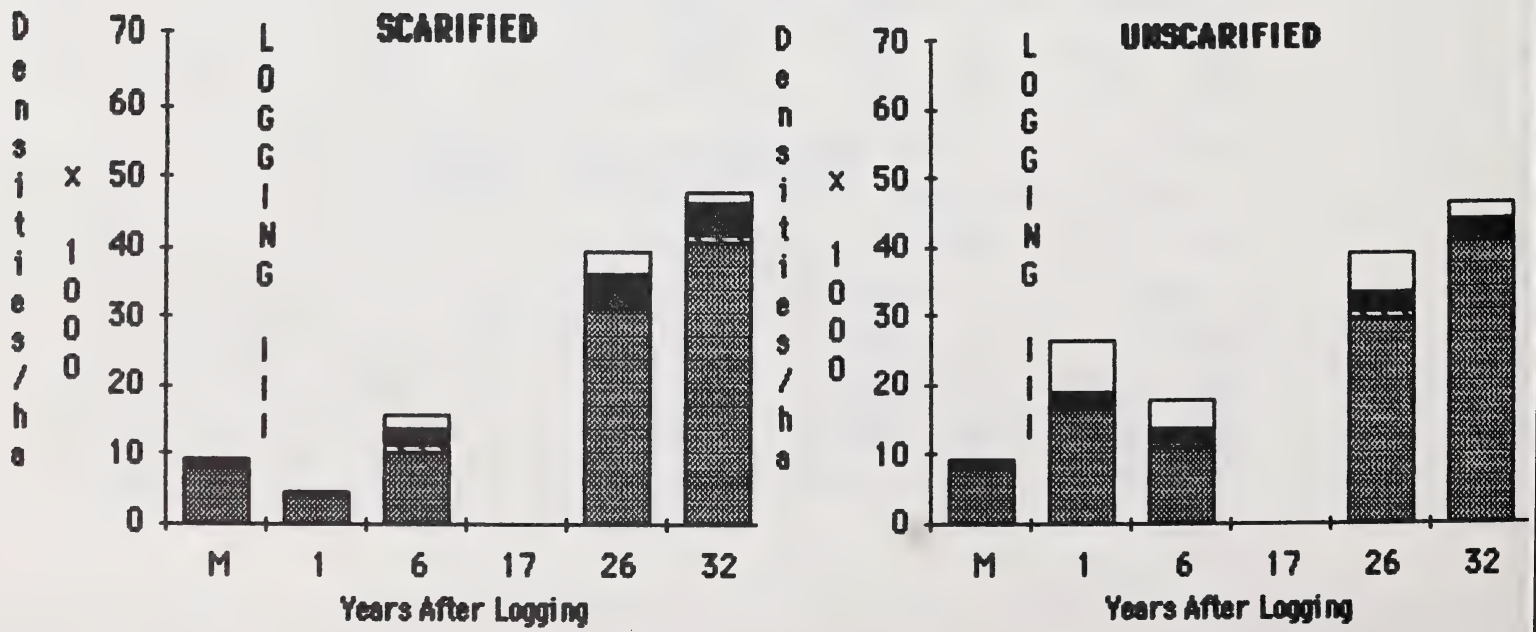

Figure 8. Trends in woody deciduous densities following logging. 
WHITE SPRUCE

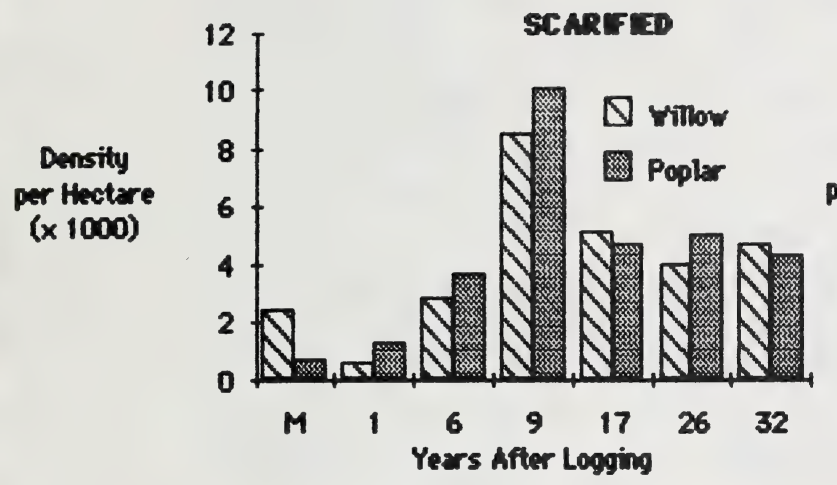

\section{LODGEPOLE PINE}

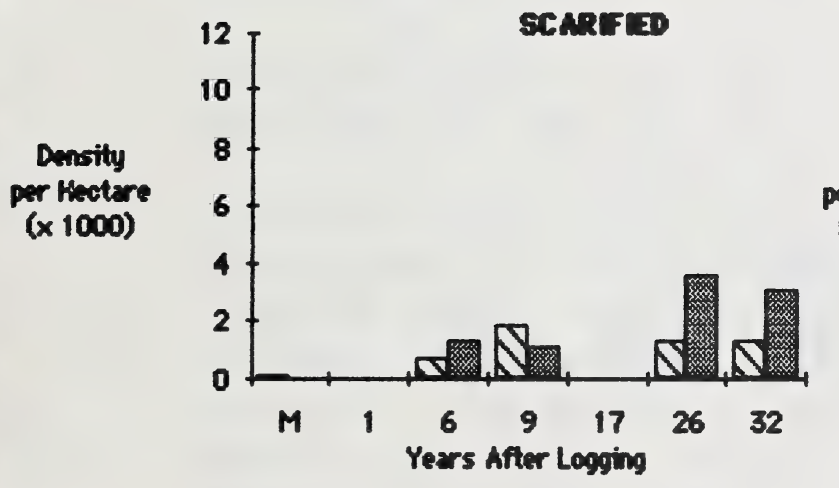

\section{MIXEDWOOD}

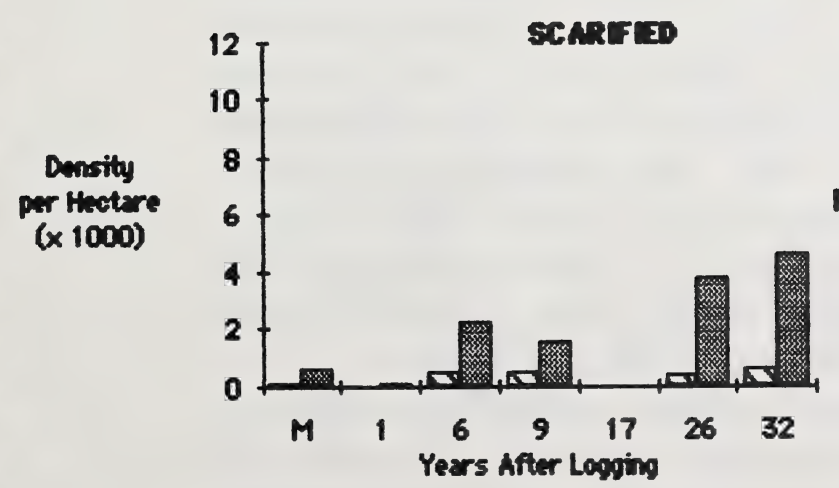

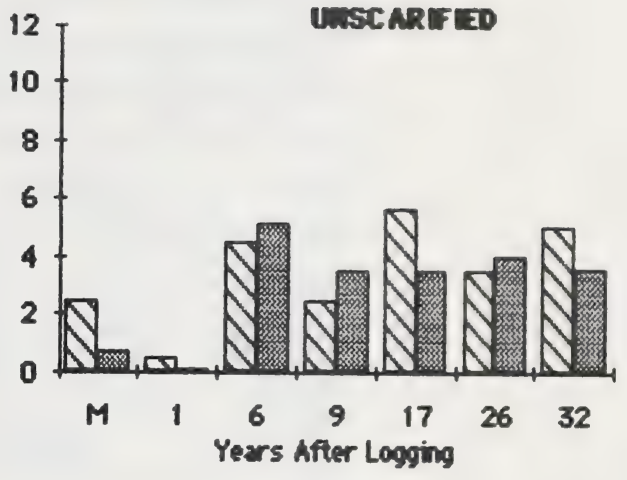

Density per Hectare (x 1000)
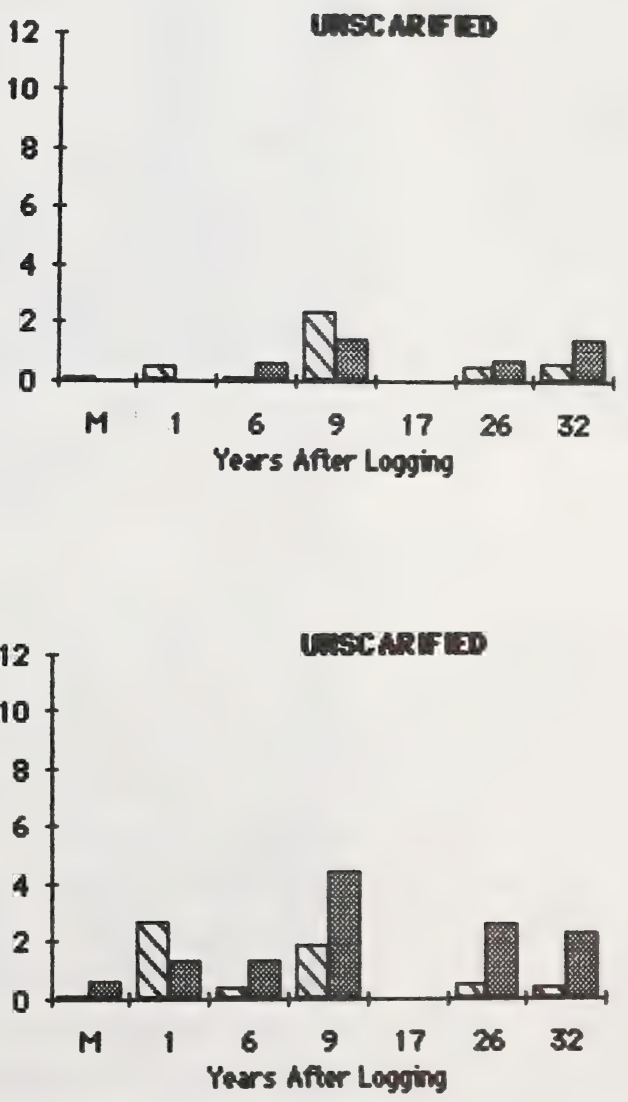

Figure 9. Trends in densities of poplar and willow following logging. 
Scandinavia have demonstrated that alder is an important contributor to soil nitrogen (Lawrence 1958, Virtanen 1962, Becking 1970). Greater heights of pine, poplar and willow in the scarified pine clear-cut may have been largely due to the higher density of alder and a corresponding higher nitrogen yield compared with values in the adjacent unscarified clear-cut (See section 4.2.4). other species that increased significantly in density during the first 32 years following logging were saskatoon, birch, honeysuckle, shrubby cinquefoil and buffalo-berry in spruce clear-cuts and gooseberry, raspberry and low-bush cranberry in pine clear-cuts. In the mixedwood forest, major changes in density following logging were with prickly rose, poplar and willow species as discussed earlier.

4.2.4 Deciduous Tree and Shrub Height - Mean heights decreased more noticeably following logging in scarified clear-cuts.

Prickly rose attained a maximum height at about Year 6 with average heights greater in unscarified clear-cuts during Years 6-32 in spruce and pine forests ( Fig. 10, Appendix 6).

During the first six years post-logging, poplar and willow heights remained below $0.7 \mathrm{~m}$ in scarified and $1.2 \mathrm{~m}$ in unscarified clear-cuts, providing inadequate escape cover for wild ungulates, except, perhaps, white-tailed deer. Mean heights were greater in unscarified than in scarified clear-cuts during Years 1-32 in both spruce and mixedwood clear-cuts. The converse was true in pine clear-cuts with heights being somewhat greater in the scarified clear-cut.

By Year 26, in the spruce forest, 20 and $34 \%$ of poplar and 14 and $18 \%$ of willow exceeded $2.4 \mathrm{~m}$ in height, in scarified and unscarified clear-cuts, respectively. Stems above $2.4 \mathrm{~m}$ are generally unavailable as browse for cervids except where moose break down young trees (Telfer and Cairns 1978). This partially explains why browse production ( $<2.4 \mathrm{~m}$ height) declined during Years 17-32 in unscarified clear-cuts (see section 4.3.2). Browse reductions had not occurred by Year 26 in the scarified clear-cut as few trees exceeded $2.4 \mathrm{~m}$ in height (Appendix 6).

Poplar and willow heights were greater in unscarified clear-cuts during Years 1-26 except in the logged pine forest (Appendix 6). They increased most rapidly in pine clear-cuts, next in mixedwood, 

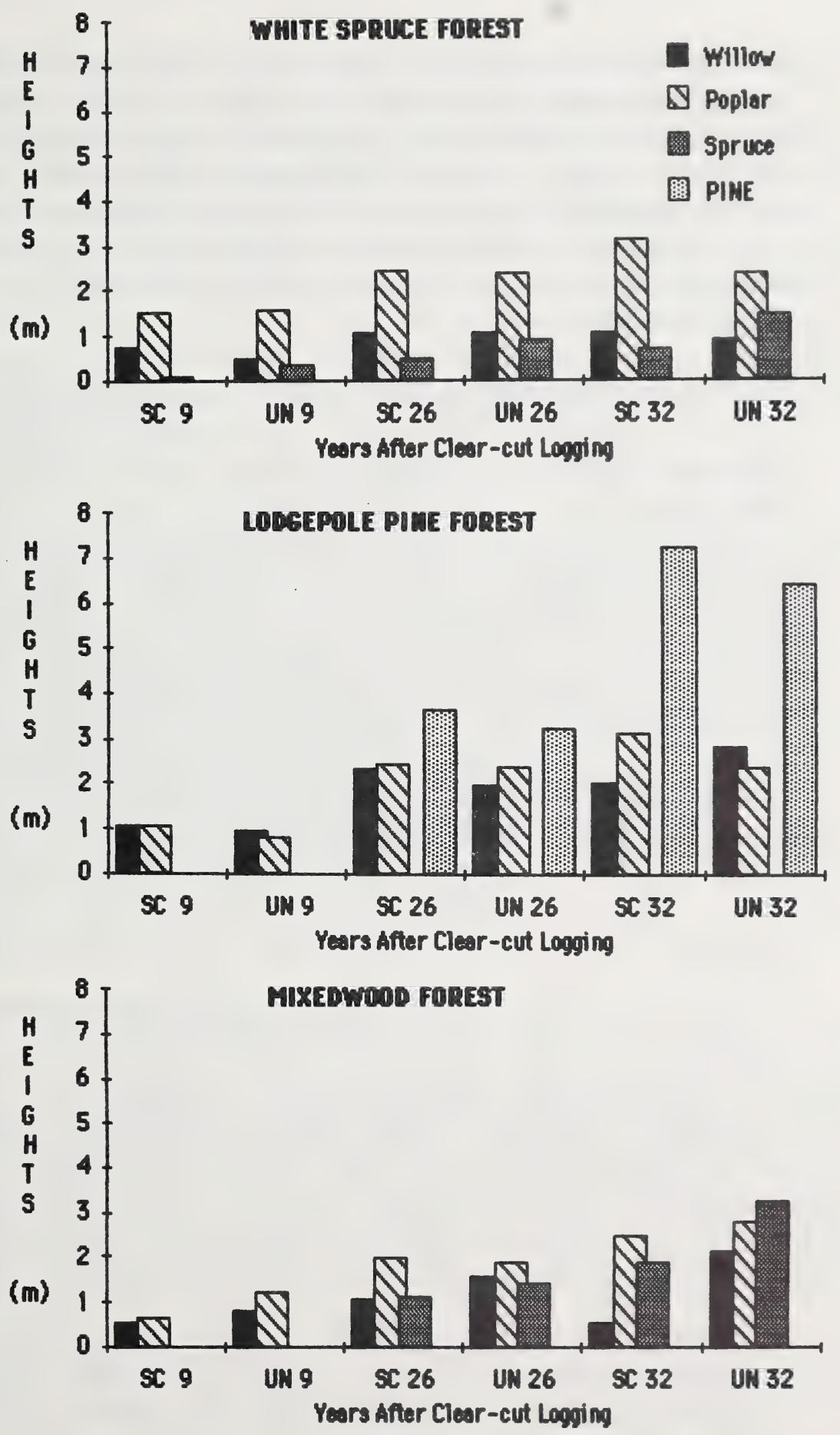

Figure 10. Changes in heights of coniferous and deciduous tree and shrub species following logging. 
and least in spruce clear-cuts. Most poplar forage was unavailable to big game in pine and mixedwood clear-cuts, while in spruce clear-cuts most poplar was still available, especially within the scarified clear-cut. Even willow species were growing beyond reach of big game animals by Year 26 , especially in pine clear-cuts where almost two-thirds had reached or exceeded $2.4 \mathrm{~m}$. Details of deciduous and coniferous heights at Year 32 in each sample area are presented in Appendix 6.

4.2.5 Coniferous Regeneration and Growth - Coniferous growth and anticipated harvest volumes were reduced by scarification in spruce and mixedwood clear-cuts but were increased in pine clear-cuts.

In the spruce forest, conifer growth was higher in unscarified clear-cuts throughout the 32 year post-logging period (Table 2). By Year 32, comparable heights were 1.5 and $0.7 \mathrm{~m}$ (Appendix 6). Stocking rate (\% of plots stocked with at least 1 conifer), annual growth rate and percent of trees taller than $5.6 \mathrm{~m}$ were also considerably higher in unscarified blocks (Table 2, Fig. 10, Appendices 5 and 6). By Year 32, there were 2.3 times more spruce/ha in scarified (9479) than unscarified (4036) clear-cuts but most were less than $1 \mathrm{~m}$ tall (Table 2, Appendix 5). Density of spruce $>2 \mathrm{~m}$ was 760 and 309/ha in unscarified and scarified

Table 2. Trends in coniferous (spruce and pine) densities (per ha) following logging.

AGE OF SPRUCE FOREST PINE FOREST MIXEDWOOD FOREST

CLEARCUT SCARIFIED UNSCAR. SCARIFIED UNSCAR. SCARIFIED UNSCAR.

\begin{tabular}{rrrrrrr}
\hline 1 & 1730 & 180 & 2783 & 0 & 0 & 2345 \\
6 & 363 & 1043 & 3080 & 619 & 118 & 73 \\
9 & - & - & - & - & - & - \\
17 & 22460 & 7575 & - & - & - & - \\
26 & 22355 & 6858 & 3894 & 2574 & 1759 & 4941 \\
32 & 9479 & 4036 & 1354 & 1272 & 3130 & 2573 \\
\hline
\end{tabular}


clear-cuts; indicating a stocking rate 2.5 times greater in unscarified than in scarified blocks of well- established spruce.

Within mixedwood clear-cuts, density of spruce in stocked plots was similar between treatments but stocking rates were 3 times higher in unscarified clear-cuts at Year 26 (Appendix 5). Annual growth rates were 1.3 times greater in unscarified clear-cuts. At Year 32, the stocking rate of conifers was 1.7 times higher in the unscarified block clear-cut, for well established spruce and pine (Appendix 5). Some conifer seedlings were planted in the scarified clear-cut so the densities and height data presented here are somewhat inflated.

Both pine clear-cuts were adequately stocked (988 seedlings/ha and $\geq 1$ seedling in $8.9 \%$ of the $0.89 \mathrm{~m}^{2}$ plots) by Year 26 (Appendix 5) with mean heights greater in scarified $(3.6 \mathrm{~m})$ than unscarified $(3.2$ m) clear-cuts (Appendix 6). By Year 32, comparable heights were 7.2 and $6.4 \mathrm{~m}$ indicating rapid growth during that 6 year period. Density of pine declined by 65 and $51 \%$ in scarified and unscarified clear-cuts between Years 26 and 32, respectively. At Year 32, there were 1080 and 815 pine/ha in scarified and unscarified clear-cuts that exceeded $6 \mathrm{~m}$ in height (Appendices 5 and 6 ).

All clear-cuts were adequately stocked with conifers at Year 26. At Year 32, all clear-cuts were still adequately stocked and average heights of spruce were significantly higher in unscarified than in scarified clear-cuts of both spruce and mixedwood forests (Fig. 10, Appendices 3, 5 and 6 ). The converse was true in pine treatments.

\subsection{Habitat and Wildifie Abundance}

4.3.1 Cover and Wildiffe Use of Clear-cuts - Results indicated that deer, elk and moose prefer some optimum combination of cover and forage. Cover (security and thermal) appeared to be a greater determinant of habitat use than forage availability (Stelfox 1984). other studies in Alberta (Tomm et al. 1981, Holroyd and Van Tighem 1983, Westworth et al. 1984) and in Saskatchewan (Hunt 1976) have shown the importance of cover and forage for deer and moose during winter.

The three mature forests provided adequate winter thermal and security cover for wild ungulates with the best cover provided by mature mixedwood, then spruce and finally pine forests (Figs. 10 and 11, Appendix 7). They were, however, largely devoid of forage with the result that big game abundance was low as indicated by 

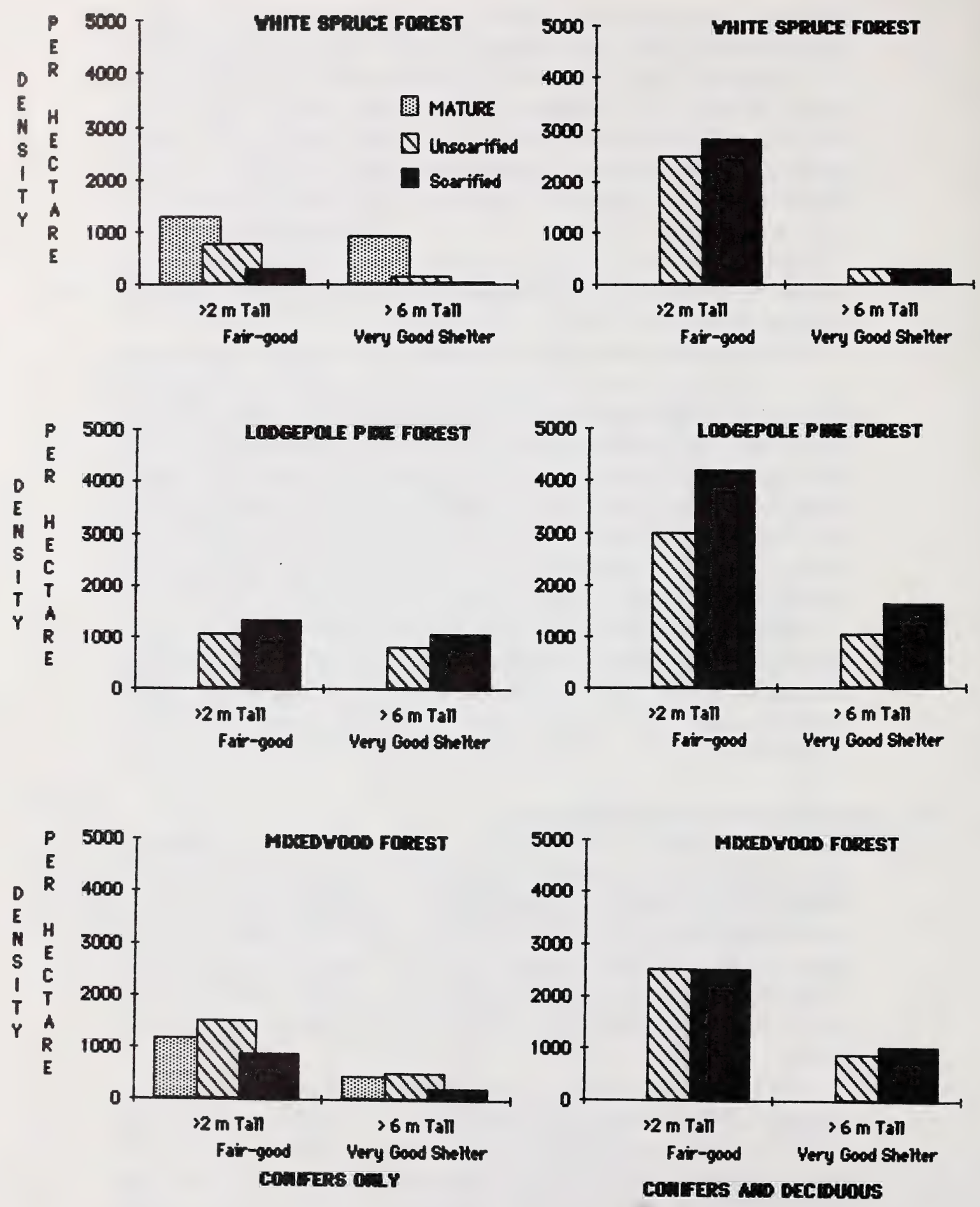

Figure 11. Winter and summer thermal shelter for wild ungulates in 32 year-old clear-cuts and mature forests. 
pellet groups/ha of 15,0 , and 15 for mature mixedwood, pine and spruce forests prior to logging compared with 100, -, and 28, respectively, 32 years later when adjacent clear-cuts were avallable for food.

During the first five years post-logging, shrubs and trees were too low to provide ungulate cover although unscarified clear-cuts provided minimum security for deer and elk in summer because of residual trees and shrubs (Figs. 2-4). The $100 \mathrm{~m}$ wide (5 chains) residual blocks, left interspersed throughout spruce and mixedwood clear-cuts for the first 12 years, although too narrow to provide good cover, were apparently providing some cover (thermal and security) because elk and moose use of clear-cuts declined sharply after the mature blocks were removed.

By Year 9, deciduous cover was adequate to provide summer security cover in spruce and mixedwood unscarified clear-cuts and in both pine clear-cuts (Figs. 2-4). Removal of mature, residual blocks at Years 12-13 in spruce and mixedwood clear-cuts decreased summer security cover and eliminated all winter thermal cover because conifer heights in the young clear-cuts were inadequate to meet minimum winter thermal cover requirements (Thomas et al. 1979). Winter thermal cover is considered minimal for deer when $75 \%$ of the area is covered by conifers at least $2 \mathrm{~m}$ tall. Adequate thermal cover does not necessarily imply adequate security cover e. g. mature-old aged conifer forests, or those with the understory deliberately removed, that provide ideal thermal cover but where cervids are conspicuous.

By Year 17, dense pine regeneration and rapid tree growth of both coniferous and deciduous plants in both pine clear-cuts resulted in moderate winter thermal/security cover for big game. The 26 year-old unscarified spruce and mixedwood clear-cuts were providing minimum winter cover at a time when browse forage was abundant and available above snow. Scarified clear-cuts lagged 5-10 years behind the unscarified clear-cuts in meeting wildlife cover requirements and at Year 26 were inadequate for winter cover but were providing adequate summer cover (Fig. 11).

By Year 26, both pine and unscarified mixedwood clear-cuts provided acceptable winter thermal/security cover plus adequate summer cover.

By Year 32, winter cover values in all clear-cuts had increased over those present in Year 26, but only pine clear-cuts were 
providing adequate winter cover (Appendices 5 and 7).

Security or hiding cover in the summer of Year 32 was best in unscarified clear-cuts, next in mature forests and lowest in scarified clear-cuts (Fig. 12, Appendix 7). Big game were $45 \%$ more visible in scarified than in unscarified clear-cuts, especially for portions of the body $>0.5 \mathrm{~m}$ above ground. For 32 year-old scarified clear-cuts, big game were most visible in mixedwood, then spruce and lastly pine. In unscarified clear-cuts, they were most visible in white spruce then mixedwood and lastly pine. Even under the mature forest canopy, they were $41 \%$ more visible than in 32 year-old unscarified clear-cuts. Mature conifers lose needles on their lower branches and become "leggy" thus providing less security cover than under younger conifers. However, animals bedded down with none of their body above $0.5 \mathrm{~m}$ above ground were only about $50 \%$ as visible as those standing (Appendix 7).

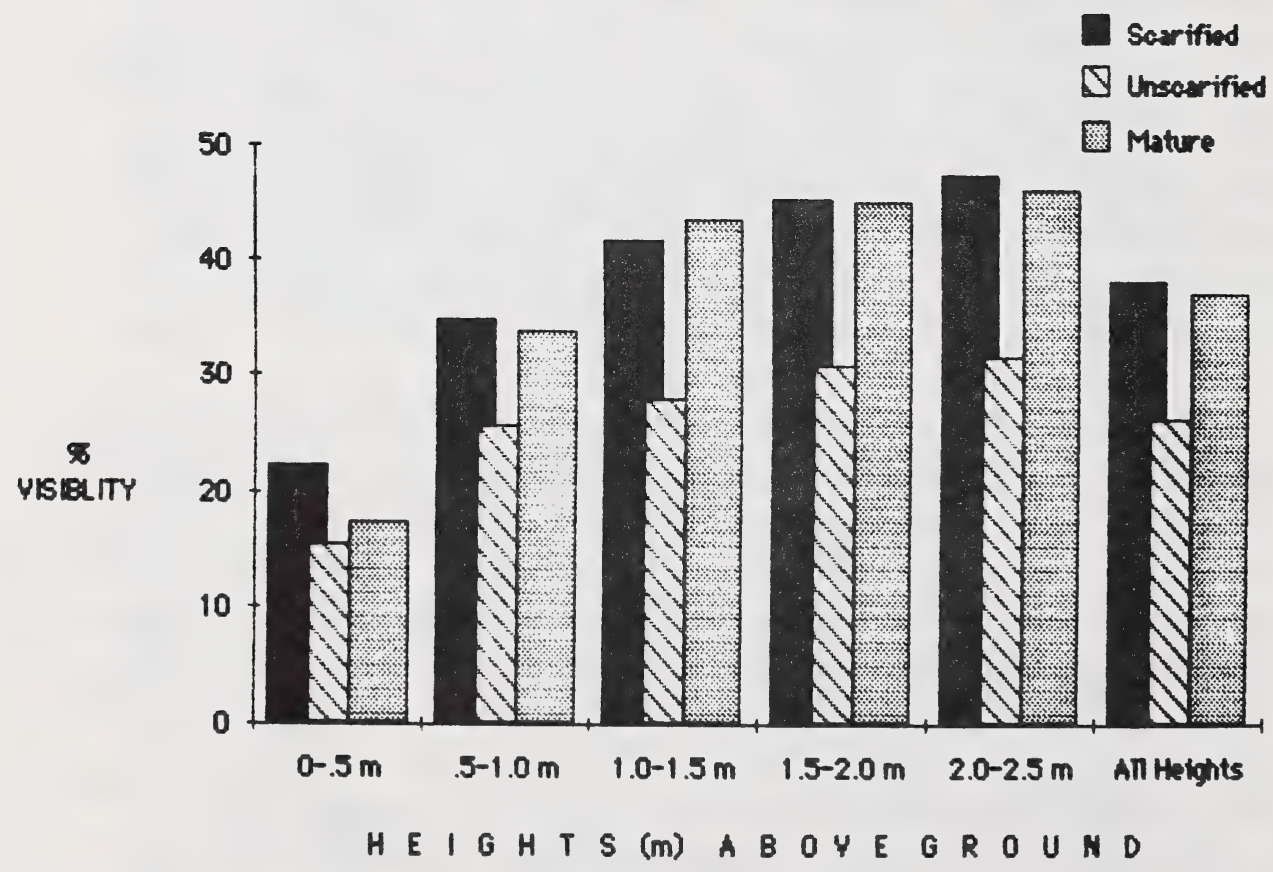

Figure 12. Summer visibility values for 5 heights above ground, averaged from spruce, pine and mixedwood forests for mature and 32 year-old clear-cuts. 
In response to these changes in quantity and quality of wildlife habitat during logging and for 32 years after, there were major changes in big game species' diversity and abundance. Big game (deer, moose elk) densities in the spruce forest, as determined from helicopter and ground surveys, declined from $1.5 / \mathrm{km}^{2}$ in the mature forest to $0.8 / \mathrm{km}^{2}$ in summer and $0 / \mathrm{km}^{2}$ in winter one year after logging in scarified clear-cuts (Stelfox 1983). By Year 5, corresponding values were 3.5 and 0 indicating that virtually all big game use during the first five years was summer use. White-tailed deer quickly moved into the clear-cuts whereas they were not observed in mature forests prior to logging. Most use during the first ten years was summer use by deer and elk with summer use increasing rapidly, especially during the period 5-10 years after logging. At Year 6, big game use was 7 and 13 times greater in mixedwood than in spruce and pine clear-cuts (Fig. 13).

During the first 17 years in spruce clear-cuts, big game use was 2.7 times greater in unscarified than in scarified clear-cuts. At Year 17, big game use was considerably greater in clear-cuts than in mature spruce although most use of clear-cuts was still summer use due to a lack of winter cover. Big game use was 59 and 9 times greater in 17 year-old unscarified and scarified clear-cuts, respectively, than in the mature spruce forest. During Years 1-27, deer, elk and moose sign (combined direct and indirect observations) was significantly greater in unscarified than scarified clear-cuts for all three forest types (Appendix 8, Stelfox 1984). For the time periods: Years 1-9, 17, 26-27, unscarified treatments had 2-27 times more big game sign than scarified treatments, when differences were significant. Unscarified spruce clear-cuts had more big game sign during Years 1-17, but not Years 26-27, than in scarified clear-cuts (Appendix 8). Within the pine forest, the unscarified clear-cut had significantly more big game use than the scarified clear-cut during Years 26-27 and 32, but not Years 1-9 (Fig. 13, Appendices 3 and 8). Because all cervids exhibited similar responses to changing habitat conditions, it suggests they reacted to the same or related habitat factors (Appendix 8).

Pine clear-cuts received considerably more use by moose than did spruce and mixedwood clear-cuts (Fig. 13). Some reasons may be greater cover (security and thermal) in 10-32 year-old pine clear-cuts compared with those in the other two forest types and a correspondingly lower harassment from human activities in pine 

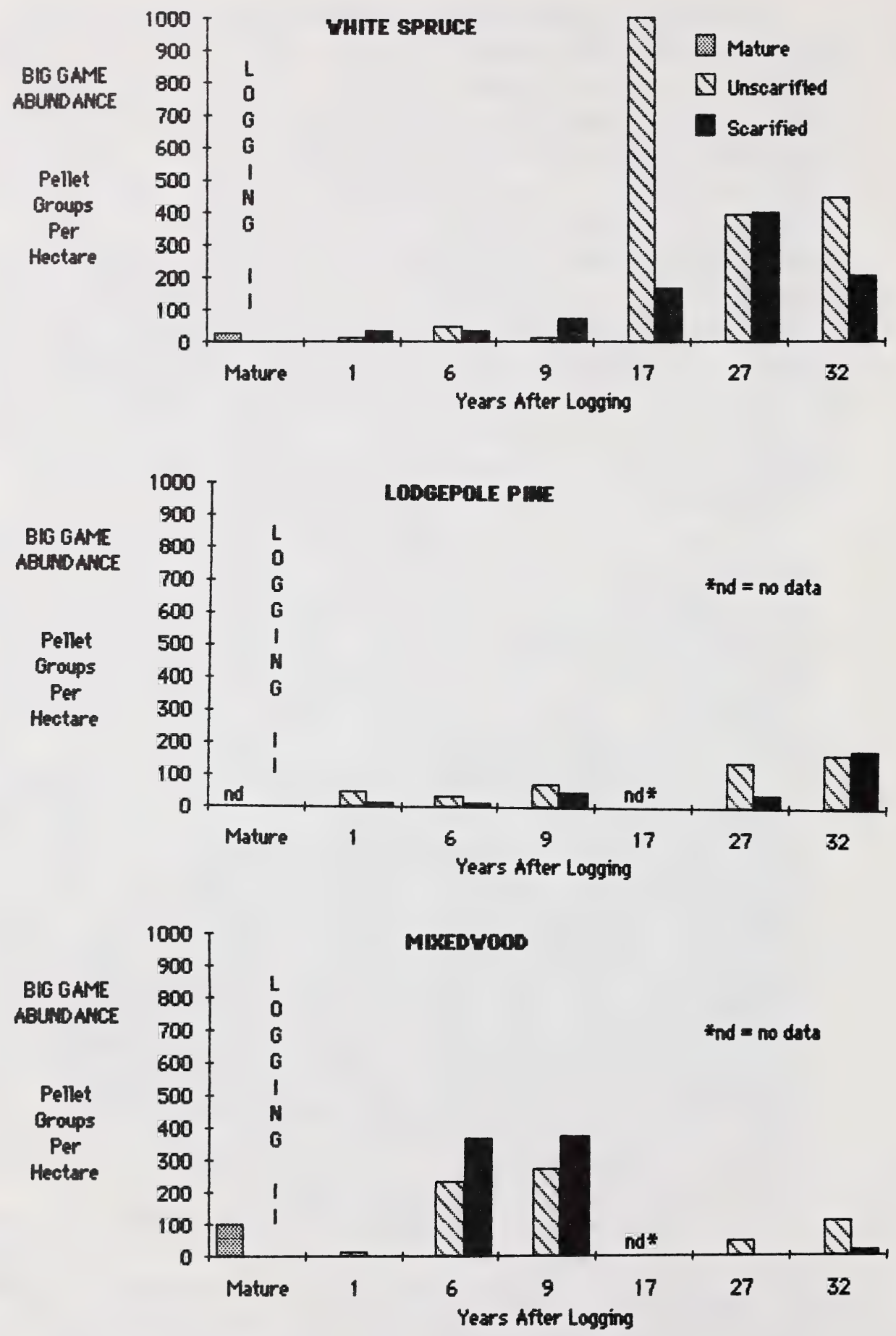

Figure 13. Changes in big game abundance following logging. 
clear-cuts. Also, abundance of alder in the pine may have enhanced habitat and increased protein content of browse forage as well as nitrogen content of the soil (Becking 1970, Virtanen 1962). Big game use of pine clear-cuts was greatest in the unscarified clear-cut during the first 32 years (Table 3, Appendix 8).

During Year 32, abundance of big game, based on pellet-group counts, was 5.7, 0.9 and 2.1 times greater in unscarified spruce, pine and mixedwood clear-cuts than in their respective scarified blocks. Deer, moose and elk use was greatest in spruce, then pine and lastly mixedwood clear-cuts (Tables 3, Fig. 13, Appendix 8). Deer and elk abundance was significantly higher in spruce and pine than in mixedwood clear-cuts (Appendix 3). Most big game use was by deer with winter use 1.9 times greater than summer use. This was the converse of Year 1 when all use was in summer. Elk use was only about $10 \%$ of that by deer. Moose did not use the spruce and mixedwood clear-cuts although in pine clear-cuts use by moose was about $28 \%$ as great as that by deer. Big game use of mature forest blocks increased 2 and 7 fold in spruce and mixedwood forests, respectively, between 1956 (prior to logging) and 1988 when forage was avallable in adjacent clear-cuts. Complete details of winter versus summer wildlife abundance and population trends during the first 32 years following logging are presented in Appendix 8.

The problem of human harassment was more evident in the mixedwood clear-cuts because they were interlaced with accessible roads and trails. Big game use actually declined after Year 9 even though forage, cover and shelter conditions continued to improve. This easy accessibility for humans caused an almost complete evacuation of the area by elk, and to a lesser extent by deer, within a week of the opening of the fall big game season. Large mammals continued to largely avoid these clear-cuts until spring when they returned to forage on new grass and forb growth. However, they were again forced from the area by continued human harassment. Use of clear-cuts by elk in Montana was also reduced by the presence of roads (Lyon and Jensen 1980). In west-central Alberta, harassment was found to be a major factor affecting the use of clear-cuts by moose (Tomm et al. 1981).

Black bears apparently require a combination of cover and food which includes an abundance of insects in rotting wood material and berry-producing shrubs (Lindsey and Meslow 1977). These were not 
Table 3. Wildlife abundance in mature forests and 32 year-old clear-cuts based on pellet groups/hectare, 1988.

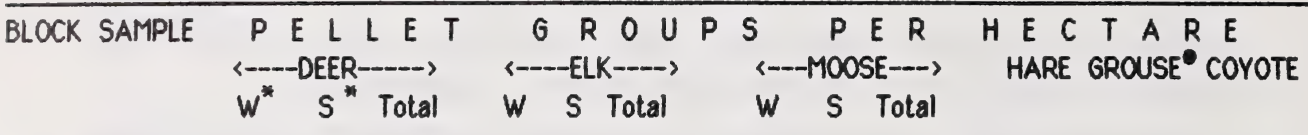

\section{MIXEDWOOD FOREST}

$\begin{array}{lrrrrrrrrrrrrr}\text { SCAR } & 1 & 0 & 20 & 20 & 0 & 0 & 0 & 0 & 0 & 0 & 0 & 50 & 0 \\ \text { UNSC } & 1 & 180 & 20 & 200 & 20 & 0 & 20 & 0 & 0 & 0 & 0 & 370 & 0 \\ & 2 & 4 & 4 & 8 & 0 & 0 & 0 & 0 & 0 & 0 & 4696 & 32 & 0 \\ \text { AVE.UNSC } & 92 & 12 & 104 & 10 & 0 & 10 & 0 & 0 & 0 & 2348 & 201 & 0 \\ \text { MATURE } & 1 & 44 & 48 & 92 & 8 & 0 & 8 & 0 & 0 & 0 & 28 & 56 & 4\end{array}$

\section{LODGEPOLE PINE FOREST}

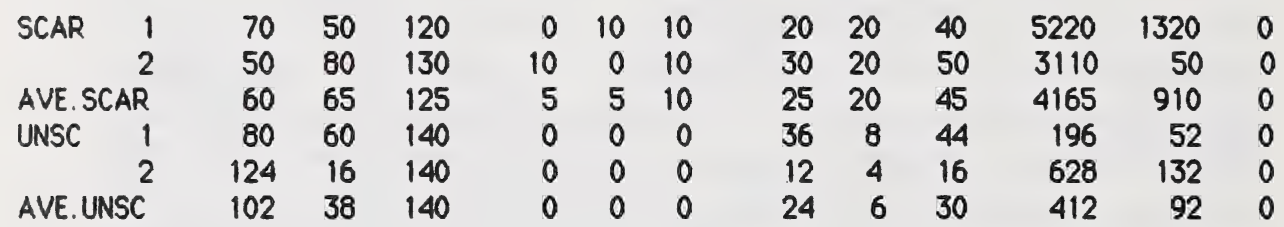

\section{WHITE SPRUCE FOREST}

\begin{tabular}{|c|c|c|c|c|c|c|c|c|c|c|c|}
\hline SCAR 1 & 108 & 60 & 168 & 20 & 24 & 44 & 0 & 0 & 0 & 16 & 36 \\
\hline & 104 & 48 & 152 & 32 & 24 & 56 & 0 & 0 & 0 & 0 & 8 \\
\hline AVE. SCAR & 106 & 54 & 160 & 26 & 24 & 50 & 0 & 0 & 0 & 8 & 22 \\
\hline UNSC 1 & 360 & 180 & 540 & 30 & 10 & 40 & 0 & 0 & 0 & 290 & 0 \\
\hline 2 & 228 & 44 & 272 & 20 & 20 & 40 & 0 & 0 & 0 & 4 & 0 \\
\hline AVE. UNSC & 294 & 112 & 406 & 25 & 15 & 40 & 0 & 0 & 0 & 147 & 0 \\
\hline MATURE 1 & 12 & 12 & 24 & 0 & 0 & 0 & $\Delta$ & 0 & 4 & 220 & 0 \\
\hline
\end{tabular}

* W = Winter $\quad \mathrm{S}=$ Summer

- Ruffed grouse in scarified spruce and mixedwood clear-cuts. Spruce grouse in mature forests and both pine clear cuts. Both species in the unscarified clear-cuts. 
common in clear-cuts until after Year 17. Studies in northern California (Kelleyhouse 1977) and in spruce-fire associations of Montana (Jonkel and Cowan 1971) showed that all recently logged areas were either avoided or minimally used by black bears. Kelleyhouse (1977) concluded that extensive logging has at least a short-term (1-10 yr) adverse impact on black bear populations. However, mixed conifer habitat was used continually. Other studies have shown that black bears are attracted to recently burned or clear-cut areas because of increased berry production (Scotter 1964, Jonkel and Cowan 1971). Bears, primarily black bears, began using clear-cuts extensively 17-25 years after logging in all three forest types. At that time rotten logs and stumps were producing an abundance of insect food, especially ants, while other important foods, such as hedysarum and buffalo-berry, were becoming more abundant. Taller deciduous and coniferous trees and shrubs were then providing adequate cover and cooler summer conditions than were younger clear-cuts. Cursory observations from this study indicated that productive bear habitat was associated with two important habitat attributes:

(1) Adequate summer cover (security and thermal) which existed when aspen, willow, alder, spruce and/or pine vegetation reached a height of at least $3 \mathrm{~m}$. Hot, open cover existing during Years 1-16 was unsuitable while taller and more dense canopy cover during latter years provided cooler conditions and adequate security cover;

(2) Abundance of food, especially ants and other preferred insects, berries such as buffalo-berries and fleshy underground plant material (hedysarum). At Year 32, use of clear-cuts by bears was similar to that observed during Years 25-27.

4.3.2 Forage Production and Use - Deciduous browse use in summer was greatest where coniferous canopy cover was lightest while during winter the converse occurred. Browse production decreased with increasing canopy closure. Scarification increased production in mixedwood and spruce clear-cuts but decreased production in pine clear-cuts. Browse production ( $\leq 2.4 \mathrm{~m}$ in height) peaked at about Year 17 in unscarified spruce and mixedwood clear-cuts and about Year 26 in scarified blocks (Table 4, Appendix 9). Peak production ( $\mathrm{kg} / \mathrm{ha}$ dry weight) was about 1240, 1070 and 420 in unscarified pine, spruce and mixedwood clear-cuts. Comparable 
Table 4a. Browse forage production (green weight $\mathrm{kg} / \mathrm{ha}$ ) in clear-cut blocks following logging.

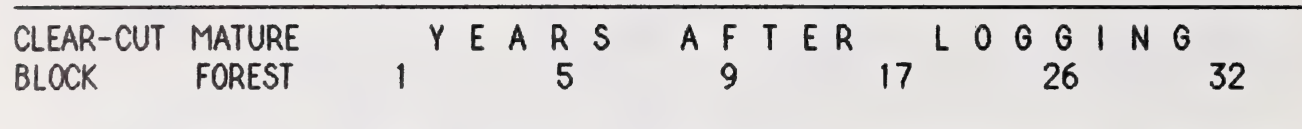

WHITE SPRUCE FOREST

Scarified

Unscarified

592

113
210

966

1615

1935
1911

2074

$2272 \quad 1838$

1662

1523

\section{MIXEDWOOD FOREST}

Scarified

Unscarified $\begin{array}{rrr}- & - & 1154 \\ - & - & 750\end{array}$ $-\quad 1302$
$-\quad 398$
739

158

\section{LODOEPOLE PINE FOREST}

Scarified

Unscarified

$-$

$\begin{array}{ll}- & 2057 \\ -\quad 2436 & 2113\end{array}$

Table 4b. Dry weight browse forage production $(\mathrm{kg} / \mathrm{ha})$ in clear-cut blocks following logging.

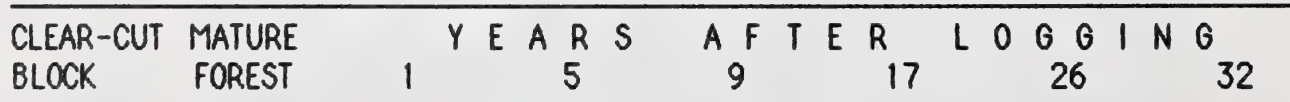

\section{WHITE SPRUCE FOREST}

Scarified

Unscarified

278

51
99

433
470

727

909

858
1068

934

906

MIXEDWOOD FOREST

Scarified

Unscarified

$\begin{array}{lll}- & - & 635 \\ - & - & 418\end{array}$

LODGEPOLE PINE FOREST

Scarified

Unscarified

$\begin{array}{rrrrrr}- & - & - & - & 1019 & 927 \\ - & - & - & - & 1195 & 1235\end{array}$


values for corresponding scarified clear-cuts were 1020, 930 and $630 \mathrm{~kg} / \mathrm{ha}$ (Table 4). These values included both leaf and twig weights. Within some Alberta aspen forests, the annual biomass yield of browse decreased with age from $210 \mathrm{~kg} / \mathrm{ha}$ at age 14 to 40 $\mathrm{kg} / \mathrm{has}$ at age 30 and $20 \mathrm{~kg} / \mathrm{ha}$ at age 60 (Westworth et al. 1984).

Both browse biomass and winter cover interacted to influence cervid browse use. ANOVA statistics indicated that both forest type and forest type-treatment interactions accounted for differences in browse use. At Year 26, pine clear-cuts had the greatest total summer plus winter consumption followed by scarified mixedwood, unscarified spruce, scarified spruce, and unscarified mixedwood (Appendix 9). Total browse consumption coincided more with degree of cover than with stem plus leaf browse production (Stelfox 1984). When only summer use is considered, the highest browse consumption occurred in both mixedwood, both pine, unscarified and then scarified spruce clear-cuts, in that order.

In summer, cervids utilized browse resources more fully where coniferous canopy closure and security cover values were low (Stelfox 1984). This was probably due to improved nutrition of plants in the sun compared with those in the shade (Cowan et al. 1950).

The large difference in yearlong use between clear-cut pine and other clear-cuts indicates that a critical combined cover value of about $50 \%$ is needed before intensive utilization takes place. It is evident that extremely low cover values result in little or no use of browse resources (e.g., Year 5, Appendix 9). Mean and total browse utilization increased over time in the spruce clear-cuts as better cover became available (Apppendix 9, Stelfox 1984). Although browse production decreased by Year 26 in unscarified clear-cuts, browse consumption was greater than in scarified clear-cuts because of superior cover.

In general, browse densities (or production) and use by big game were greater in unscarified treatments, except for Years 26 and 32 when scarified spruce and mixedwood produced more browse. This indicates that total consumption averaged greater in unscarified treatments during Years $1-26$ in all forest types.

of the main browse species, use by big game animals was heaviest on rose, willow, and poplar in that order of decreasing use (Appendix 9). Utilization was heaviest in mixedwood, then pine and 
least in spruce clear-cuts. Two highly preferred species present in low densities in the pine forest were mountain ash (Sorbus scopulina) and alpine fir as shown in Fig. 14. Big game use of mountain ash had removed $75 \%$ of new leaf and stem growth by late August in 32 year-old pine clear-cuts. By that time, at least $50 \%$ of new growth of young alpine fir seedlings and saplings had also been consumed by moose, deer and elk. This strong preference for these two species has prevented them from achieving normal density and growth in the young pine forest and has resulted in what could be termed a "zootic-impaired" tree community. Mountain ash and alpine fir were not found on low-elevation spruce and mixedwood clear-cuts. Alder was only present in pine clear-cuts and there it received an average utflization of $11.1 \%$ by big game, somewhat more than for poplar but less than for willow (Stelfox 1984). Utilization of less than 5\% for poplar, willow and rose (Appendix 9) at Year 26 supports the contention that browse forage was under-utilized and the range stocking rate of moose, deer and elk well below the range carrying capacity from a food availability perspective.

Grass and forb cover and species diversity increased significantly, especially in scarified blocks, during the first six years resulting in increased summer use of clear-cuts by deer and elk. Only light use of grasses occurred during Years 1-32 with greatest use during Years 1-6. Preference of the most abundant grasses during Years 1-6 in spruce clear-cuts, in decreasing order of preference were timothy, rush, bromegrass, sedge and hairy wild rye. Use of grasses and forbs in mature forests was negligible prior to logging. Deer and elk in summer used the diverse and abundant growth of forbs within clear-cuts during these early years. of 26 forb species present in clear-cuts but not in mature blocks, many were eaten by deer and elk. Seven species or genera that comprised $90 \%$ of forb diet (cover $x$ ave. use) in spruce clear-cuts during Years 1-5 were hedysarum $27.9 \%$, fringed gentian (Gentianella crinata) $14.0 \%$, tall mertensia $13.4 \%$, asters $12.1 \%$, blue columbine (Aquilegia brevistyla) $7.8 \%$, thin-leaved ragwort (Senecio pseudaureus $7.7 \%$, and smooth camas $7.3 \%$. However, the ten most highly preferred forbs, in decreasing order of preference were: lamb's quarter (Chenopodium album), harebell (Campanula rotundifolia), blue columbine, fringed gentian, Indian paint-brush (Castilleja spp.), smooth camas, western wood lily (Lilium 

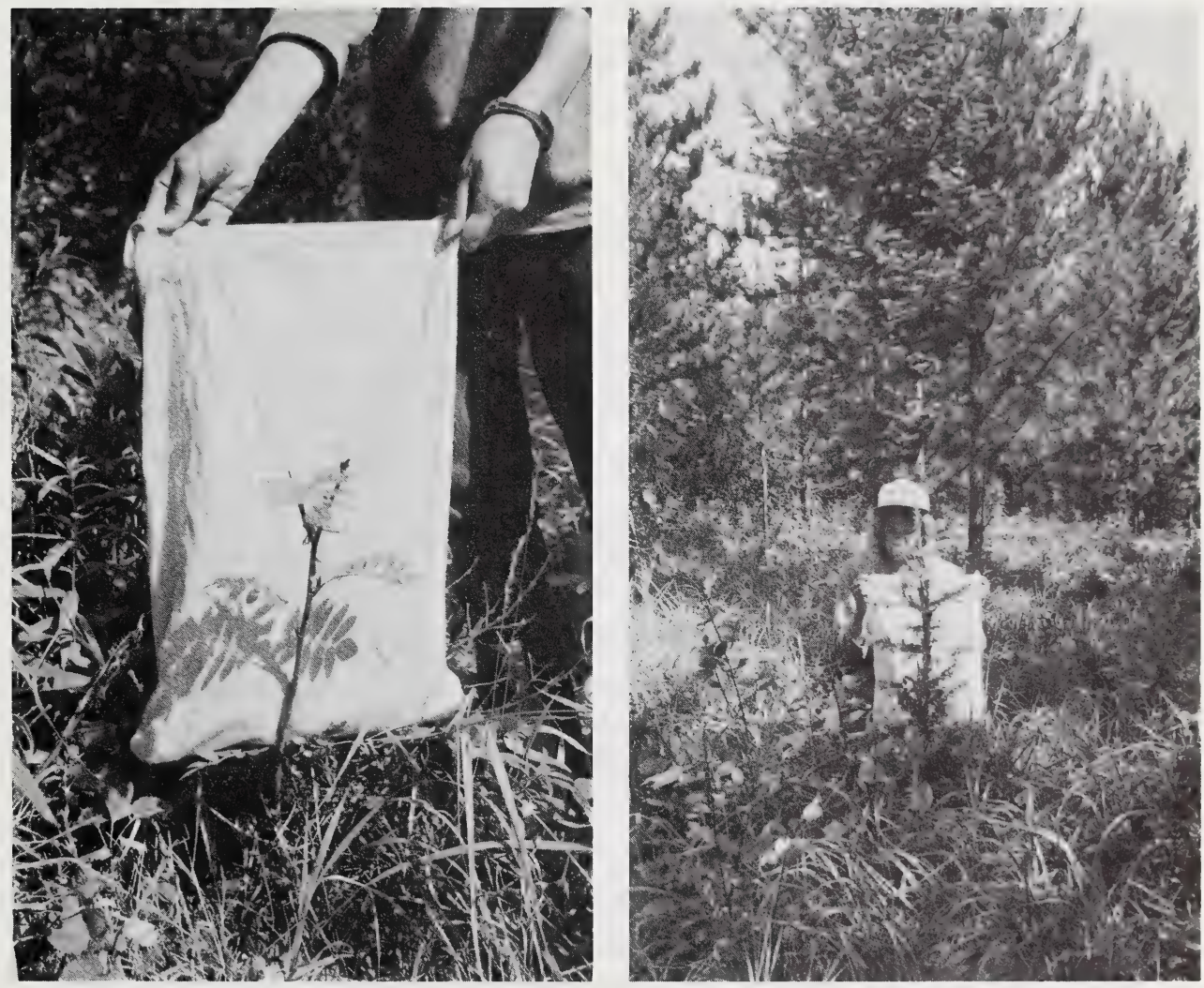

Mountain Ash (Sorbus scopulina)

Alpine Fir (Abies lasiocarpa)

Figure 14. Preferred big game browse species, mountain ash and alpine fir, being suppressed in a 32 year-old lodgepole pine forest. 
philadelphicum), asters, thin-leaved ragwort, and hedysarum.

At Year 26, big game use of forbs averaged $2.8 \%$ in mixedwood and $0.1 \%$ or less in spruce and pine clear-cuts. Comparable values for big game use of grasses were $<0.1 \%$ in mixedwood, $0 \%$ in spruce, and $0.1 \%$ in the pine clear-cuts. There was a significant difference $(p<0.01)$ in forb use among the three forest types, with pine treatments tending to be higher in scarified but lower in unscarified clear-cuts compared with the other two forests (Stelfox 1984).

At Year 32, big game use of forbs and grasses was similar to that recorded in Year 26.

4.3.3 Winter Forest/Wildlife Interactions - Security (hiding) and thermal cover was a greater determinant of habitat use of clear-cuts by deer, elk and moose than forage availability, as shown in earlier sections. Mature coniferous blocks, at least $100 \mathrm{~m}$ wide, were essential for winter thermal and security cover during the first 15-20 years following logging of the pine forest and the first 25 years following logging of spruce and mixedwood forests. Where these latter forests were scarified following logging, mature residual blocks interspersed throughout the clear-cuts were required for at least 30 years after initial logging.

There was a strong negative correlation $(r=-0.77)$ between wildlife abundance and wind chill, indicating that winter residents avoid clear-cuts with poor shelter values (Fig. 15). Wildlife abundance represents the sum of all direct and indirect observations using an identical survey technique and time period for all blocks. (Stelfox 1984). There was also a negative correlation $(r=-0.72)$ between animal visibility and wildlife abundance. The correlation between crown closure and wildifie abundance was strongly positive in spruce but less positive in pine and mixedwood clear-cuts.

At Year 26, winter wildlife stocking rates were greatest in mixedwood treatments where they were twice as great as in spruce and 1.5 times greater than in pine treatments. Critical cover values of about 50\% for each of security and coniferous canopy are needed before intensive yearlong use of clear-cuts by big game will occur (Fig. 15). The greatest diversity of animal species was in unscarified clear-cuts of all forests, then scarified clear-cuts, and lastly in mature blocks.

There was a positive correlation between abundance (winter 


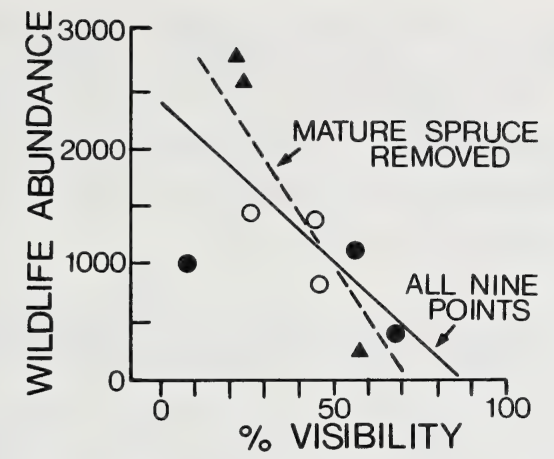

- WHITE SPRUCE

$\triangle$ MIXED WOOD

O LODGEPOLE PINE

y INTERCEPT $=2,291$

SLOPE $=-26.7$

$r=-0.72$

(ALL NINE POINTS)

y INTERCEPT $=3,325$

SLOPE $=-46.06$

$r=-0.89$

(SPRUCE REMOVED)

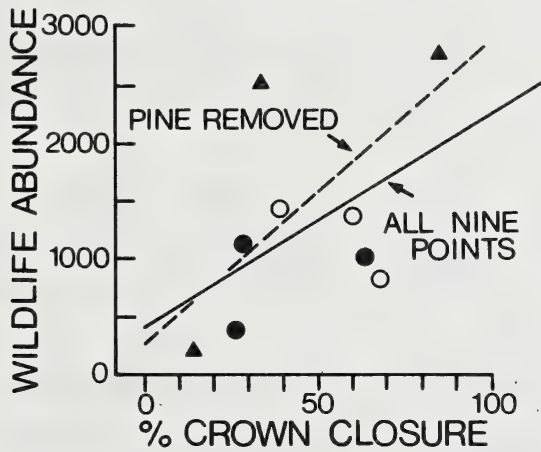

y INTERCEPT $=443$

SLOPE $=22.6$ $r=0.63$

( ALL NINE POINTS)

y INTERCEPT $=253$

SLOPE $=25.9$

$r=0.65$

(PINE REMOVED)

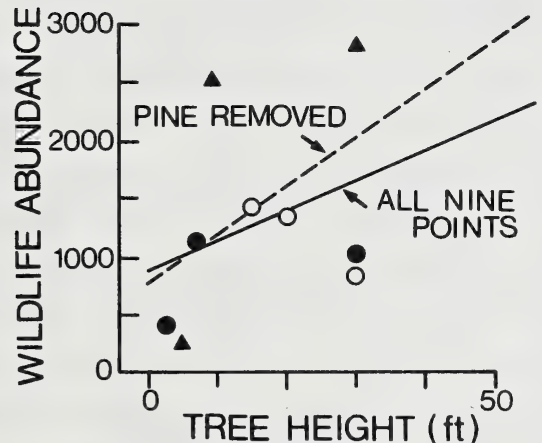

y INTERCEPT $=869$

SLOPE $=26.2$

$r=0.35$

(ALL NINE POINTS)

$\mathrm{y}$ INTERCEPT $=755$

SLOPE $=42.2$

(PINE $r=0.50$

(PINE REMOVED)

CONIFEROUS

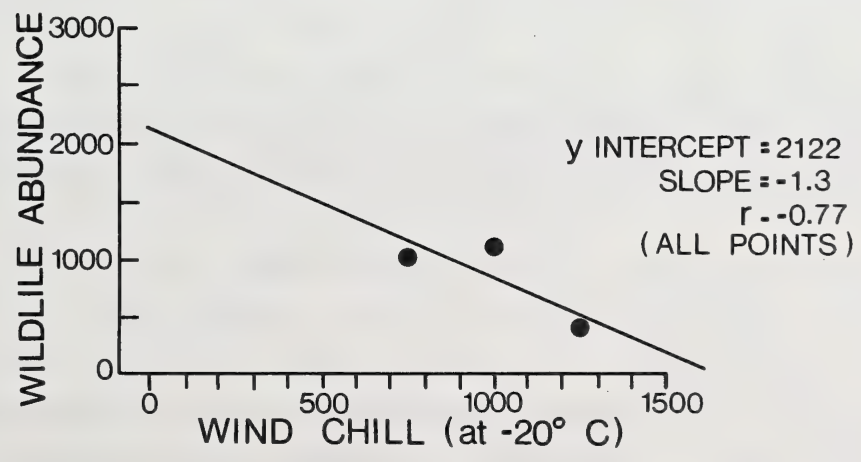

Figure 15. Correlations between winter wildlife abundance and security cover (\% visibility), conifer crown closure, conifer height and wind chill. 
track counts) of mice and two of their predators, namely coyotes and weasel. Mice were most abundant in unscarified clear-cuts, especially in white spruce, then in scarified clear-cuts and lastly in mature blocks. This abundance was positively correlated with percent foliage cover of grasses (Stelfox 1984).

4.3.4 Potential and Actual Use of Clear-cuts by Big Game - Big game populations, with the exception of white-talled deer, did not increase proportionate to the extent of increases in range carrying capacities of clear-cuts during the first 32 years following logging. General ratings of clear-cuts' ability to support big game and the actual abundance of big game are presented for five time periods (Table 5).

As mentioned earlier, white-tailed deer numbers increased quickly following logging. The large increase in big game use during the first 17 years in the clear-cuts was almost entirely summer use by white-tailed and mule deer. Road access and continuous harassment from human activities, plus inadequate cover, appeared mainly responsible for elk and moose populations failing to increase proportionate to increased habitat carrying capacities. Considering clear-cuts in all three forests, big game abundance increased up to Year 17 but then declined sharply by Year 26 . Even though big game use was 9 and 59 times greater in 17 year-old scarified and unscarified clear-cuts, respectively, than in the mature spruce forest, the carrying capacity of browse forage exceeded the actual stocking rate by about 40:1 (Stelfox et al 1974 and 1976). Carrying capacities of browse forage at Year 17 were estimated at $6.7,2.8$ and 0.6 hectares per moose, elk and deer for scarified and 4.4, 2.1 and 0.4 hectares, respectively, for unscarified clear-cuts. Stated another way, the 17 year-old scarified forage could theoretically support 35 moose, 74 elk or $382 \mathrm{deer} / \mathrm{km}^{2}$ or 48 moose, 103 elk or 536 deer $/ \mathrm{km}^{2}$ in unscarified clear-cuts, providing cover conditions were adequate and harassment not significant (Stelfox et al op. cit).

Something suppressed big game numbers well below the range carrying capacity of clear-cut blocks during Years 25-27 and 32 . Human harassment and corresponding insecurity for big game, especially elk and moose, were believed largely responsible. Other limiting factors such as predation, disease/parasitism and inclement weather were not believed to be significant mortality 
Table 5. Potential and actual use of clear-cuts by big game.

YEARS AFTER LOGGING

F $0 \quad R$

White Spruce $\begin{array}{ccc}\text { E } & \text { T T T } \\ \text { Lodgepole Pine }\end{array}$

$Y$ P E S

Mixedwood

\begin{tabular}{|c|c|c|c|c|c|c|c|}
\hline & & Scar & Unsc & Scar & Unsc & Scar & Unsc \\
\hline & & ABILIT & Y of CLI & R-CUTS & O SUPPORT & BIO GAME & \\
\hline $1-11$ & $\begin{array}{l}\text { Summer } \\
\text { Winter }\end{array}$ & $\begin{array}{l}\text { Fair } \\
\text { Poor }\end{array}$ & $\begin{array}{l}\text { Good } \\
\text { Poor }\end{array}$ & $\begin{array}{l}\text { Good } \\
\text { Poor }\end{array}$ & $\begin{array}{l}\text { Good } \\
\text { Poor }\end{array}$ & $\begin{array}{l}\text { Fair } \\
\text { Poor }\end{array}$ & $\begin{array}{l}\text { Good } \\
\text { Poor }\end{array}$ \\
\hline $12 \& 13$ & \multicolumn{7}{|c|}{ Residual Coniferous Blocks Removed in Spruce and Mixedwood Clear-cuts } \\
\hline $14-17$ & $\begin{array}{l}\text { Summer } \\
\text { Winter }\end{array}$ & $\begin{array}{l}\text { Falr } \\
\text { Poor }\end{array}$ & $\begin{array}{l}\text { Good } \\
\text { Poor-fair }\end{array}$ & $\begin{array}{l}\text { Good } \\
\text { Fair }\end{array}$ & $\begin{array}{l}\text { Good } \\
\text { Fair }\end{array}$ & $\begin{array}{l}\text { Fair } \\
\text { Poor }\end{array}$ & $\begin{array}{l}\text { Good } \\
\text { Poor-fair }\end{array}$ \\
\hline $18-25$ & $\begin{array}{l}\text { Summer } \\
\text { Winter }\end{array}$ & $\begin{array}{l}\text { Good } \\
\text { Poor }\end{array}$ & $\begin{array}{l}\text { Good } \\
\text { Fair }\end{array}$ & $\begin{array}{l}\text { V. Good } \\
\text { Good }\end{array}$ & $\begin{array}{l}\text { V. Good } \\
\text { Good }\end{array}$ & $\begin{array}{l}\text { Fair } \\
\text { Poor }\end{array}$ & $\begin{array}{l}\text { Good } \\
\text { Fair }\end{array}$ \\
\hline $26-32$ & $\begin{array}{l}\text { Summer } \\
\text { Winter }\end{array}$ & $\begin{array}{l}\text { V. Good } \\
\text { Fair }\end{array}$ & $\begin{array}{l}\text { V. Good } \\
\text { Fair-Good }\end{array}$ & $\begin{array}{l}\text { V. Good } \\
\text { V. Good }\end{array}$ & $\begin{array}{l}\text { V. Good } \\
\text { V. Good }\end{array}$ & $\begin{array}{l}\text { Good } \\
\text { Poor-fair }\end{array}$ & $\begin{array}{l}\text { V. Good } \\
\text { Good }\end{array}$ \\
\hline
\end{tabular}

\section{RELATIYE ABUNDANCE RATINOS OF BIO CAME*}

White Spruce

1-11 Summer

Winter

$$
D^{1} E^{2} \text { moderate }
$$

nil

$$
\text { Lodgepole Pine }
$$

DEM $M^{3}$ moderate nil - light
Mixedwood

$\begin{array}{ll}\text { DE } & \text { moderate } \\ M & \text { nil } \\ & \text { nil }\end{array}$

12 \& 13 Residual Coniferous Blocks Removed in Spruce and Mixedwood Clear-cuts

$\begin{array}{lllllll}\text { 14-17 } & \text { Summer } & \text { DE light } & \text { DEM moderate } & \text { DE } & \text { light } \\ & \text { Winter } & \text { nil light } & \text { DEM light } & & \text { nil } \\ 18-25 & \text { Summer } & \text { DE moderate } & \text { DEM moderate } & \text { DE } & \text { light } \\ & \text { Winter } & \text { nil light } & \text { DEM moderate } & & \text { nil } \\ \text { 26-32 } & \text { Summer } & \text { DE light } & \text { DEM moderate } & \text { EM nil } \\ & \text { Winter } & \text { D light D moderate } & \text { DEM moderate } & \text { D light D light }\end{array}$

1 Deer

2 Elk

3 Moose

* Deer use of clear-cuts was mostly by whitetails in the spruce and mixeotwood clear-cuts and by both whitetails and mule deer in pine clear-cuts. The abundance of moose in the spruce and mixedwood clear-cuts was virtually nil, except during Years 1-11 before the coniferous residual blocks were removed when their abundance was light. 
factors during this study. Hunting may have suppressed moose and elk populations (Regional Biologist K. G. Smith pers. comm.) As stated earlier, security cover and winter shelter attributes were inadequate for the first 15 years at least, especially in scarified blocks. However, these requirements were being met to a greater degree each year so moose, deer and elk populations should have increased correspondingly but didn't (Table 3, Figs. 10-13, Appendix 7 and 8), except for pine clear-cuts (Fig. 13). For spruce and mixedwood clear-cuts there was a decrease in big game abundance between Years 26 and 32, in both scarified and unscarified clear-cuts.

The recent, large gravel pit operation within the mixedwood clear-cut (Fig. 16) undoubtedly affected big game use of both clear-cuts during Years 25-32. During Years 26 and 27, summer and winter studies showed negligible big game sign within $335 \mathrm{~m}$ of gravel pit activities. Old logging trails remained passable for motorized vehicles throughout Years 1-32 and received increased use by varlous vehicles during summer and winter. During the summer of Year 32, when gravel pit operations were still active, mixedwood clear-cuts were being used by less than six whitetalls and no elk or moose. Conversely, in spruce clear-cuts along the same valley where vehicular use was denied, 6-12 whitetails, 3-5 mule deer and 5-6 elk were using a similar sized area during the summer of Year 32.

4.3.5 Upland Game-bird Trends - Grouse were absent or scarce during Years 1-15 (Grass-forb and Shrub-seedling stages). Only 25\% of grouse observations during the first 27 years occurred during Years 1-15 compared with 75\% during Years 16-27 (Pole-sapling stage) as shown in Appendix 10. Mixedwood clear-cuts were most productive (59\% of observations), then white spruce, (32\%), and lastly lodgepole pine (9\%), during Years 16-27. More grouse were observed in unscarified clear-cuts (86\%) compared with $14 \%$ for scarified.

Spruce grouse were not seen in any clear-cuts during the first 15 years although they were common in all three mature forests. A small summer population of ruffed grouse was observed in unscarifled mixedwood as were blue grouse in scarifled spruce and sharp-tailed grouse in scarified pine clear-cuts, during Years 1-15. The first spruce grouse observed in the clear-cuts was Year 17 

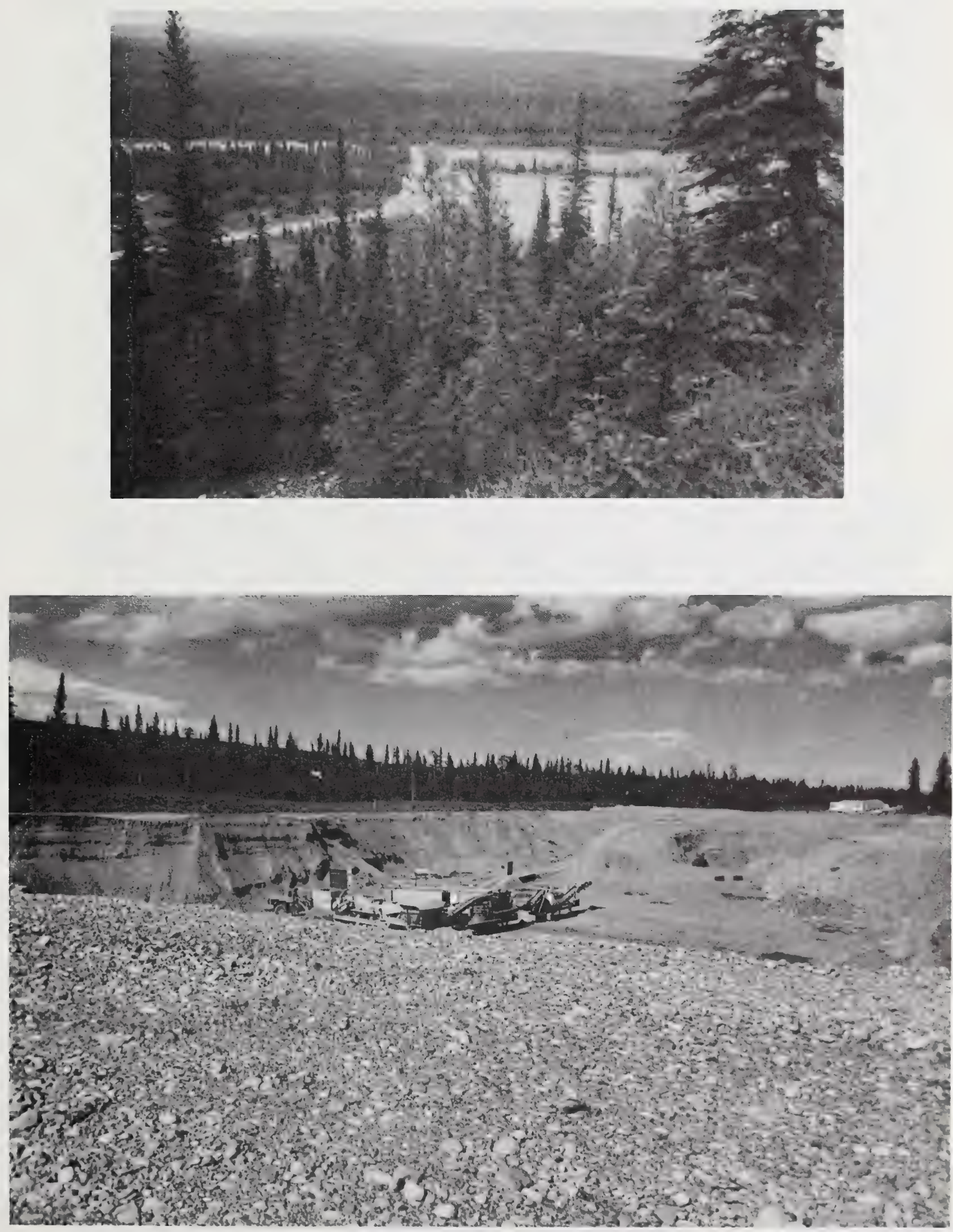

Figure 16. Gravel pit operations in scarified and unscarified mixedwood clear-cuts, 26-32 years after logging. 
in unscarified spruce, Year 26 in unscarified mixedwood and Year 27 in unscarified pine. They comprised only $10 \%$ of the grouse seen during Years 1-27. Most (86\%) were in unscarified clear-cuts.

in Year 32, spruce grouse were abundant in both pine clear-cuts (Table 3) while ruffed grouse were observed in the transitional zone between these pine clear-cuts and the open, deciduous cover adjacent to the perimeter road. Grouse were more abundant in the scarified pine clear-cut. In mixedwood clear-cuts, ruffed grouse were found in scarified, both spruce and ruffed grouse in unscarified clear-cuts, and only spruce grouse in the adjacent mature forest. In spruce clear-cuts, no spruce or ruffed grouse sightings or signs were observed in the unscarified block while three broods of ruffed grouse were seen in the scarified clear-cut, in addition to an average of 22 faecal groups/ha (Table 3, Appendix 10).

The most abundant grouse for all clear-cuts was ruffed grouse which accounted for $72 \%$ of all grouse seen during Years 1-27. During Years 1-15, they accounted for only $44 \%$ of the grouse compared with $81 \%$ during Years 16-27. No ruffed grouse were seen in the unscarified pine clear-cut during Years 1-32 while 2 were seen in the scarified clear-cut during Years 16-27 (Table 3, Stelfox 1984).

Sharp-tailed grouse were only observed in the scarified pine clear-cut at Year 3 during the Grass-forb forest successional stage.

Blue grouse summered only in the spruce scarified clear-cut near the mountains during Years 1-26. They did not occur in the adjacent unscarified and mature spruce blocks nor in the mixedwood and pine blocks that were more than $15 \mathrm{~km}$ from the mountains. One brood was seen in the summer of Year 3 and three single adults were seen during the summers of Years 25 and 26 (Stelfox 1984). None were seen in winter.

During Years 1-27, only $11 \%$ of the grouse were observed during winter indicating that these young clear-cuts were generally not providing adequate winter cover. However, in Year 32, both pine and spruce clear-cuts appeared to be supporting grouse equally well in winter and summer.

During Years 25-27 and 32, unscarified spruce and pine clearcuts had $10 \%$ or less as much grouse sign as did their scarified counterparts (Table 3, Stelfox 1984). In mixedwood clear-cuts, abundance of grouse was 4 times greater in unscarified than in scarified and mature clear-cuts (Table 3 ). 
4.3.6 Tree Cavity-Dwelling Wildlife - At least 38 cavity-dependent species on the Weldwood lease rely on snags for nesting (McCallum 1984). Their association with snags of various diameters and the abundance of snags in three mixedwood forest blocks are present in Table 6 and Appendix 11). This group of wildlife disappeared from the scarified clear-cuts following logging as no trees with cavities remained. Within the unscarified clear-cuts, only a small portion of decadent and dead trees were removed during logging. Large poplar trees, in particular, were essential for maintaining populations of woodpeckers (pileated, hairy, downy, northern three-toed, yellowbellied sapsucker, flicker), nuthatches (red-breasted, whitebreasted), chickadees (boreal and black-capped), mountain bluebird, starling, swallows (tree and violet-green), house wren, kestrel, saw-whet owl and ducks (bufflehead, goldeneye and hooded merganser) as well as flying squirrels and big brown bats. The red squirrel and marten also disappeared while such species as shorttailed weasel and least chipmunk were undoubtedly affected because of the loss of trees and logs with cavities that result from scarification following logging. The density of trees with cavities after logging was much higher in mixedwood, then spruce, and lastly pine clear-cuts. Correspondingly, $84 \%$ of woodpecker and $79 \%$ of chickadee sightings were in the unscarlfied mixedwood clear-cut during Years 1-27 (Appendix 10). Three hawks (goshawk, merlin and sharp-shinned) were seen only in unscarified and mature treatments. Dickson et al (1983) found bird species richness, abundance and diversity were significantly higher in plots with snags than in snagless plots. They also found that many non cavity-nesting birds used snags for foraging and perching and were more abundant on plots with snags. A study in Oregon and Washington determined that 39 bird and 23 mammal species used snags for nesting or shelter and that a direct relationship existed between the number of snags and the number of snag-dependent wildlife in the forest (Thomas et al. 1979).

In Year 32, the density of tree snags in unscarified clear-cuts was highest in pine $(43 / \mathrm{ha})$, next in mixedwood $(23 / \mathrm{ha})$ and then in spruce $(22 / \mathrm{ha})$ forests (Appendix 11). However, the greatest density of snags with cavities was in mixedwood (17), then pine and spruce (7) unscarified clear-cuts. Almost $75 \%$ of snags in mixedwood unscarified clear-cuts contained cavities compared with only $32 \%$ in spruce and $16 \%$ in pine unscarified clear-cuts. The 
Table 6a. Density of snags, percent with cavities and percent being used by wildlife in three mixedwood forest blocks.

\begin{tabular}{|c|c|c|c|c|}
\hline & & MATURE & \multicolumn{2}{|c|}{32 YEAR OLD } \\
\hline \multicolumn{2}{|c|}{ Snag Density/Hectare } & 76 & 23 & 0 \\
\hline \multirow[t]{5}{*}{ Wildife Use } & a) Woodpecker' & 0 & 3 & 1 \\
\hline & b) Flicker & 0 & 2 & 0 \\
\hline & c) Chickadee & 0 & 1 & 0 \\
\hline & d) Starling & 0 & 2 & 0 \\
\hline & Total Wildife & 0 & 8 & 1 \\
\hline 8 of Snags & $10-20 \mathrm{~cm} \mathrm{DBH}$ & $5.3(0)$ & $14.3(7)$ & $0(0)$ \\
\hline with Cavities & $20-30 \mathrm{~cm} \mathrm{DBH}$ & $2.3(0)$ & $58.3(17)$ & $0(0)$ \\
\hline and $X$ of Snags & $30-35 \mathrm{~cm} \mathrm{DBH}$ & $0(0)$ & $66.7(100)$ & $0(0)$ \\
\hline Being Used & $35-50 \mathrm{~cm} \mathrm{DBH}$ & $0(0)$ & $50.0(33)$ & $0(0)$ \\
\hline
\end{tabular}

IPlleated and northern three-toed woodpeckers

Table $6 \mathrm{~b}$. Wildlife species that will use tree snags of various diameters.

\begin{tabular}{|c|c|c|c|c|}
\hline $\begin{array}{l}S N A G \\
15-20\end{array}$ & $\begin{array}{c}D \perp A M E T E R \\
20-30\end{array}$ & $\begin{array}{l}\mathrm{I} N \\
30-35\end{array}$ & $\begin{array}{c}E N T \text { I ME } \\
35-50\end{array}$ & $\begin{array}{l}R \text { R S } \\
>50\end{array}$ \\
\hline $\begin{array}{l}\text { Chickadees } \\
\text { Downy Woodpecker }\end{array}$ & $\begin{array}{l}\text { Yellow-bellied Sapsucker } \\
\text { Hairy Woodpecker } \\
\text { Tree Swallow } \\
\text { Violet-Green Swallow } \\
\text { House Wren } \\
\text { Bluebird } \\
\text { Starling } \\
\text { Short-tailed Weasel } \\
\text { Chipmunk } \\
\text { Deer Mouse }\end{array}$ & $\begin{array}{l}\text { Kestrel } \\
\text { Saw-whet OwI } \\
\text { Northern 3-Toed- } \\
\text { Woodpecker } \\
\text { Nuthatch (white \& } \\
\text { redbreasted) } \\
\text { Red Squirrel } \\
\text { Flying Squirrel } \\
\text { Big Brown Bat }\end{array}$ & $\begin{array}{l}\text { Bufflehead Duck } \\
\text { Hooded Merganser } \\
\text { Marten }\end{array}$ & $\begin{array}{l}\text { Goldeneye Duck } \\
\text { Pileated - } \\
\text { Woodpecker }\end{array}$ \\
\hline
\end{tabular}


density of snags was 2-3 times greater in mature unlogged forests than in adjacent unscarified clear-cuts (Table 6, Appendix 11). Snags were absent in scarified clear-cuts of mixedwood and spruce forests while there was a density of 15/ha in the scarified pine clear-cut (Appendix 11). It is expected that under a timber management rotation cycle of $80-90$ years, decadent and dead snags with diameters greater than $30 \mathrm{~cm}$ dbh will be virtually non-existent. That will result in a major decline in those 15 bird and mammal species that use decadent and dead trees with diameters $>30 \mathrm{dbh}$ (Table $6 \mathrm{~b}$ ). The exception could be the red squirrel and marten that probably exist without snags.

4.3.7 Avifauna General - Considering all bird species, 54\% of bird observations were in mixedwood, $25 \%$ in spruce, and $21 \%$ in pine clear-cuts. Hawks (Accipiter and Buteo spp.) and falcons (Falcc spp.) predominated in mixedwood clear-cuts, especially in the unscarified clear-cut. Sparrows (Passerculus, Spizella, Zonotrichia and Melospiza spp.), siskins and juncos (Junco hyemalis) were present in similar abundance in all three forest types (Stelfox 1984 and Appendix 10). The results are consistent with the findings of Welsh (1981) who concluded that population density and diversity of bird populations was greater within boreal mixedwood than within pine and spruce forests. The greater diversity of plant communities and plant species within the mixedwood forest provides more resources for more bird species than do forests dominated by one tree species (e.g. White spruce or lodgepole pine). The abundance and diversity of resources for birds are further enhanced in unscarified clear-cuts especially those containing unmerchantable trees such as aspen and balsam poplar of various sizes. Although the number of bird species seen in scarified and unscarified clear-cuts was similar, 21 and 22, respectively, there were major differences in species associated with each treatment. Ten species were observed only in unscarified clear-cuts: hairy woodpecker, yellow-bellied sapsucker (Sphyrapicus varius), goshawk, merlin (Falco columbarius) sharp-shinned hawk (Accipiter striatus), cedar waxwing, common snipe (Gallinago gallinago), upland sandpiper (Bartramia longicauda), mountain bluebird (Sialia currucoides), and starling (Sturnus vulgarus). The seven species seen only in scarified clear-cuts were sharp-tailed and blue grouse, Swainson's hawk (Buteo swainsoni), white-crowned (Zonotrichia leucophrys, 
and song sparrows (Melospiza melodia), hummingbirds (Selasphorus and Stellula spp.) and red-eyed vireo (Vireo olivaceus).

4.3.8 Furbearing Mammals and Prey Species - Furbearer numbers were depleted following clear-cut logging although weasels, coyotes and lynx appeared to respond somewhat to increased densities of mice and hares between Years 6 and 17. Furbearer numbers remained scarce to Year 17 but by Year 26, red squirrels were common in all unscarified but scarce in scarified clear-cuts. For all forest types, at Year 26, red squirrels were 31 and 4 times more abundant in mature forests than in scarified and unscarified clear-cuts, respectively (Fig. 17). Considering all five species (squirrel, weasel, lynx, coyote and wolf), their abundance in mature forests was 17 and 3 times greater than in scarifled and unscarified clear-cuts, respectively. In mixedwood treatments (all three combined), the abundance of furbearers was 9 and 7 times greater than in spruce and pine forest treatments, respectively, at Year 26. Red squirrels were especially more abundant in mature forests while weasels and lynx were more abundant in clear-cuts (Fig. 17).

At Year 26 in the pine forest, snowshoe hare abundance was greatest in scarified, then unscarified clear-cuts (Stelfox 1984). At Year 32, abundance was 10 times greater in the scarified clear-cut. The converse was true in mixedwood and spruce forests where hares were abundant in unscarified, but absent or scarce in scarified clear-cuts which had inferior thermal and security cover (Table 3, Figs. 11 and 12). Recent girdling of conifers was light at Year 32 compared to Years 25-27 although the abundance of hares was still high in pine and mixedwood forests (Table 3). Hare girdling of 25-27 year-old pine was 41\% higher in the scarified pine clear-cut and this was correlated with higher hare abundance (15\%), coniferous density (64\%), deciduous tree/shrub density (6\%), and heights of pine, poplar and willow compared with the unscarified clear-cut (Table 7). These results agree with other studies showing hares preferred dense coniferous cover near a diverse food source (Poll 1981, Sullivan and Sullivan 1982). Deciduous browse forage biomass was $17 \%$ greater in the unscarified clear-cut and this greater food source may have also contributed to the lighter damage to pine (Table 7 ).

Pine trees girdled more than $40 \%$ will usually die (Radvanyi 1987). About $28 \%$ of pine in scarified and $23 \%$ in unscarified 
Table 7. Snowshoe hare damage to 26 year-old pine trees correlated to coniferous and deciduous tree densities and heights.

\begin{tabular}{lcc}
\hline & $\begin{array}{c}26 \text { YEAR-OLD } \\
\text { SCARIFIED }\end{array}$ & $\begin{array}{c}\text { CLEAR-CUTS } \\
\text { UNSCARIFIED }\end{array}$ \\
\hline 8 All Pine Girdled & 67.0 & 47.5 \\
8 Pine Girdled 1-508 & 38.0 & 24.5 \\
8 Pine Girdled 51-1008 & 28.5 & 23.5 \\
8 Pine With No Girdling & 33.0 & 52.5 \\
Ave. Pine Height (m) & 6.2 & 4.6 \\
Ave. Poplar Height (m) & 3.8 & 3.3 \\
Ave. Willow Height (m) & 3.0 & 2.8 \\
Deciduous Browse Biomass (kg/ha) & 1019 & 1190 \\
Deciduous Tree/Shrub Density/ha & 39960 & 37530 \\
Hare Density (Pellets/ha) & 24950 & 21750 \\
Coniferous Density/ha & 3995 & 2430 \\
Alder Density & 2592 & 1835 \\
\end{tabular}

clear-cuts will likely die because they were girdled more than $50 \%$ (Table 7 ). The number of trees girdled more than $40 \%$ increased by $9.5 \%$ between Years 26 and 27 in scarified compared with $0.5 \%$ in unscarified clear-cuts.

Vitality of pine trees girdled at least $75 \%$, as measured by percent of needles that were red, was greater for tall $(>6 \mathrm{~m})$ than for small trees (Fig. 18). A higher mortality rate of severely girdled ( $>75 \%)$ trees can thus be expected for small trees ( $<6 \mathrm{~m}$ tall).

Pine trees were not only damaged by snowshoe hares but also by red squirrels (Fig. 19). Rather than girdling the trunk near its base, squirrels stripped bark from the stem to feed on the cambium and sapwood. Not only were strips of bark removed at distances of 2-5 $\mathrm{m}$ above ground but frequently the stem was completely girdled. 


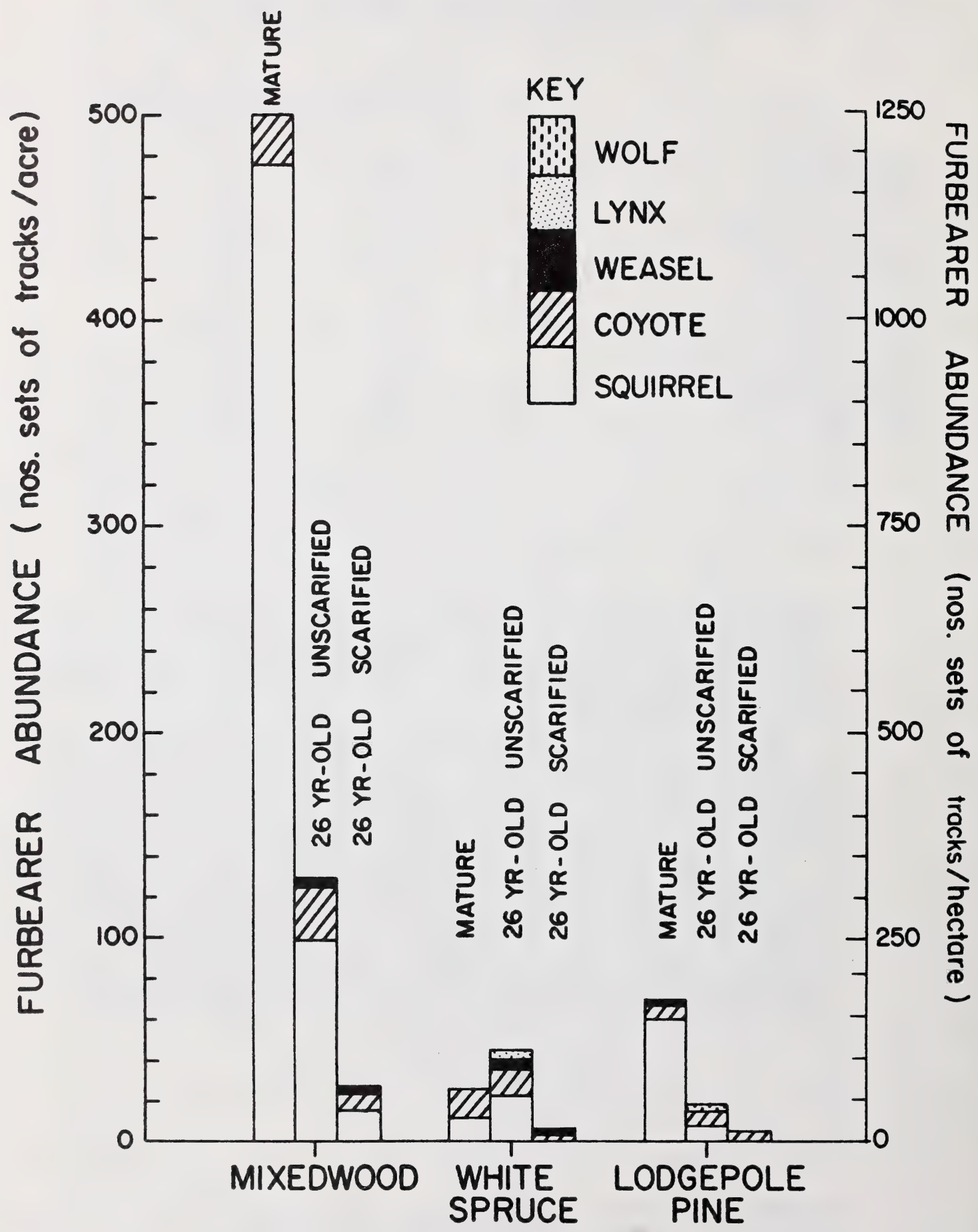

Figure 17. Furbearer abundance in mature and 26 year-old clear-cuts, based on winter track counts. 


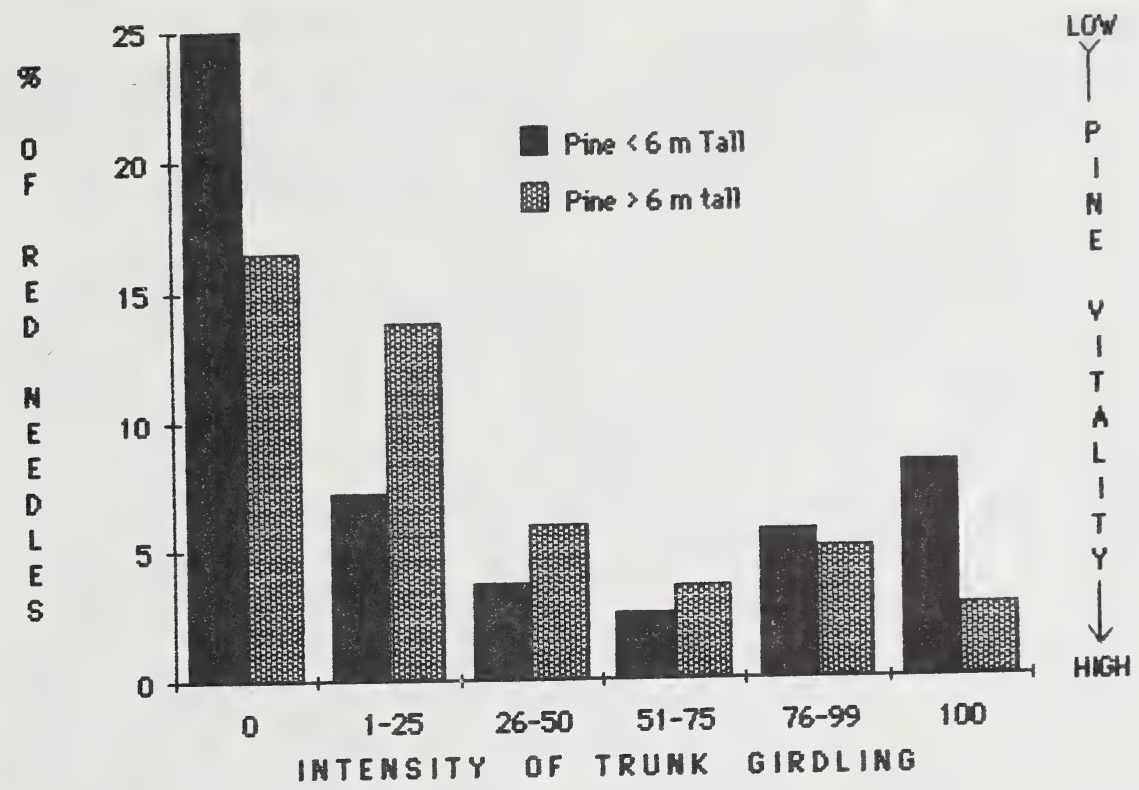

Figure 18. Vitality of girdled pine trees less than and greater than 6 metres in height.
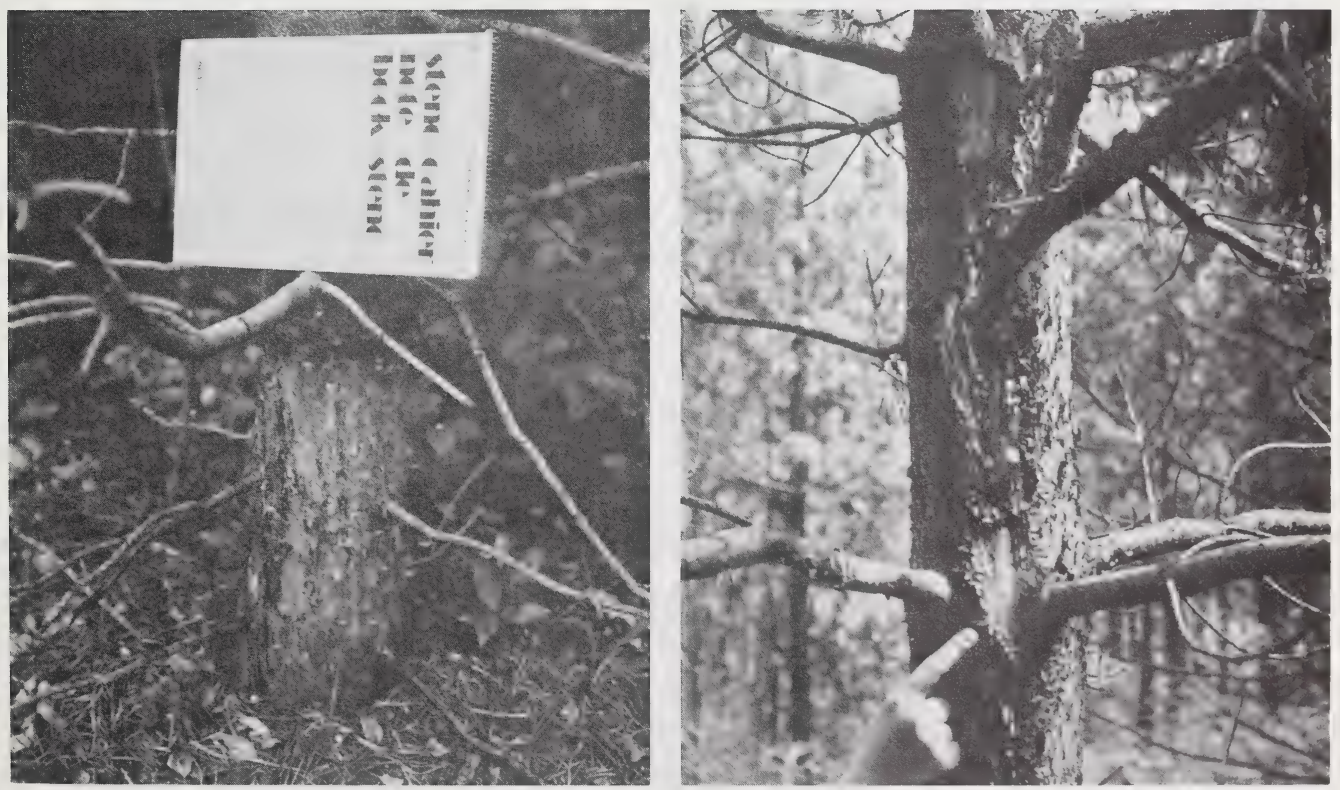

Figure 19. Girdling of 26 year-old pine by snowshoe hares (left) and damage by red squirrels (right). 


\subsection{SUMMARY AND CONCLUSIONS}

Studies of forest succession, wildlife and habitat changes were conducted over a 32 year period (1956-1988) following clear-cut logging in white spruce, lodgepole pine and mixedwood forests in west-central Alberta.

Following logging, one-third of the old age spruce remained as intervening blocks between clear-cuts until 12-13 years after initial logging when they were removed. About $20 \%$ of the mature mixedwood forest was also left as residual blocks for the first 10-15 years after logging. None of the 283 ha logged pine forest contained mature unlogged blocks although about one-half of the area was left unscarified, as it was in the mixedwood clear-cut. In the spruce clear-cut only one block was left unscarified and reserved. Scarification consisted of using Caterpillar tractors equipped with rippers attached to the lower edge of the blade. Unmerchantable trees and shrubs were pushed down and the herb, grass and moss layers mixed with the upper $25-50 \mathrm{~cm}$ of soll. For the pine clear-cut, scarification consisted of merely pushing down all unmerchantable trees and shrubs and crushing the slash with Caterpillar tractors. For all study areas, logging and scarification occurred during 1956 and 1957.

Major differences occurred in wildifife densities and habitats, between scarified and unscarified, between clear-cuts and unlogged mature forests, and among the three forest types. Major differences in relation to forest succession stages were:

Grass-forb (Herb-dwarf shrub) stage ( $1-10$ years)

Grass (grass and sedge) and forb (herb) biomass and species diversity increased significantly following logging, resulting in increased summer use by deer and elk that fed on this abundant forage. Grass cover increased 4 fold by Year 6 while the number of species also increased, compared with those in unlogged forests. Grass cover increases were greatest in pine, then spruce and least in mixedwood clear-cuts. Forb cover increased 2-3 fold after logging with greatest increases in scarified clear-cuts. At Year 5 in spruce clear-cuts, there were 26 forb species not evident in the mature forest, and many were preferred forages for elk and deer. By Year 32, grass and forb cover had declined to values somewhat higher than those in mature forests.

The open, low-growth plant communities favored ground nesting passerine birds but were unfavourable for tree nesting, perching, and tree cavity-dwelling avifauna. Light summer use by blue and sharptailed grouse occurred while spruce and ruffed grouse were absent. 
Furbearer numbers were depleted following clear-cut logging although weasels, coyotes and lynx responded somewhat to increased densities of mice and hares, between Years 6 and 17. Snowshoe hare numbers remained low during this successional stage.

The overall abundance and diversity of resident wildlife species was scant in scarified clear-cuts because the three essential habitat requirements (forage, escape cover, shelter or thermal cover) were deficient. Winter forages for moose, deer and elk were too low to be available beneath the blanket of snow. Wind-chill conditions were unfavourable due to a lack of tall coniferous trees essential for thermal cover. Unscarified clear-cuts provided some forage plus winter cover and thus received light winter use by wildlife. However, most winter use occurred within mature residual blocks and in nearby unlogged forests. Tree cavity-dwelling bird species remained in unscarifled clear-cuts where suitable tree snags remained but not in scarified clear-cuts, where snags had been removed.

Shrub Stage $(11-20$ years)

Poplar, willow and alder provided the conspicuous vegetative overstory at heights of 1.5-2.5 m and provided summer escape cover plus yearlong forage for big game animals, especially in unscarified clear-cuts. In pine, plus unscarified spruce and mixedwood clear-cuts, conifers were conspicuous. Conifers were still too small to provide adequate winter cover for big game, except in pine clear-cuts where their density and height were providing minimum winter cover during the later part of this period. During the first 17 years, big game use was 2.7 times greater in unscarified than in scarified spruce clear-cuts. This was mainly summer use by deer and elk due to a lack of winter cover. Big game use was 50 and 9 times greater in 17 year-old unscarified and scarified spruce clear-cuts, respectively, than in the mature spruce forest. Big game use declined temporarily following the removal of residual blocks of mature forest at Years 12-15 in spruce and mixedwood clear-cuts, because original clear-cuts were not providing adequate cover.

Ruffed grouse were common in unscarified spruce and mixedwood clear-cuts. Spruce grouse were absent in all clear-cuts during the first 15 years but were common in all three mature forests. They were first observed in the unscarified spruce clear-cut at Year 17, at Year 26 in unscarified mixedwood and at Year 27 in unscarified pine clear-cuts. Sharp-tailed grouse were absent during both the Shrub and Pole-sapling stages. 
Tree cavity-dwelling wildlife, bears and most furbearing mammals remained scarce in scarified clear-cuts until after Year 17. Unscarified clear-cuts were superior to scarifled ones for the above wildife groups.

Snowshoe hare numbers remained low but somewhat higher than during the Grass-forb stage, especially in unscarified spruce and mixedwood clear-cuts.

Pole-sapling (young orowth) Stage (15-25 years for Mixedwood and Pine, 20-40 years for Spruce clear-cuts)

Poplar and willow were still the conspicuous tree/shrub species in lowland spruce and mixedwood clear-cuts, especially the scarified ones. Conifer regeneration met provincial stocking rate standards in all clear-cuts by Year 26 although major differences existed in density, distribution and height between scarified and unscarified blocks. In the upland pine forest at Year 26, the density of conifers, tall enough to provide minimum winter thermal cover $(>2 \mathrm{~m})$ for cervids, was higher in scarified (1337/ha) than in unscarified clear-cuts (1084/ha). The converse was true in lowland spruce and mixedwood forests where densities were higher in unscarified (760 and 1491/ha, respectively) than in scarified (309 and 890) clear-cuts.

Greater density and height of conifers in pine compared with spruce and mixedwood clear-cuts resulted in superior winter cover and greater use by cervids in the former, at Year 26. Similar differences were observed in abundance of grouse and snowshoe hares. Adequate winter thermal cover occurred first in both scarified and unscarified pine clear-cuts 15-20 years after logging, then in unscarified spruce and mixedwood clear-cuts at Years 25-30. Scarified clear-cuts did not provide adequate winter cover for cervids during this stage.

Moderate use of clear-cuts by bears during the period 17-32 years post-logging was associated with an abundance of insect food in rotten stumps and logs, berries such as buffalo-berry, adequate escape cover, and probably cooler summer habitats than those in younger clear-cuts.

Browse forage production peaked at about Year 17 in unscarified spruce and mixedwood clear-cuts and about Year 26 in scarified ones. Thermal and security cover influenced cervid use of clear-cuts more than forage. Blocks of mature coniferous forest, at least $100 \mathrm{~m}$ wide and interspersed throughout clear-cut blocks, were essential for winter cover during the first 15-20 years following logging of the pine forest and the first 25-30 years in spruce and mixedwood clear-cut areas. Where these latter clear-cuts were also scarified, then mature residual 
blocks interspersed among clear-cuts were needed for at least 32 years after logging.

The return of spruce grouse to pine and mixedwood clear-cuts, with the exception of the scarified mixedwood, was apparent during Years 25-32. The tall, dense stand of lodgepole pine on pine clear-cuts was no longer suitable for ruffed grouse which were increasing in abundance in mixedwood and spruce clear-cuts.

Furbearing mammals, which were depleted following logging, were increasing in abundance, especially the red squirrel that was common in all unscarified clear-cuts by Year 26 . The combined abundance of five furbearers (coyote, wolf, lynx, weasel, squirrel) was 17 and 3 times greater in mature forests than in 26 year-old scarified and unscarified clear-cuts. They were also 7-9 times more abundant in mixedwood than in spruce and pine forest blocks.

Snowshoe hare abundance was high in all clear-cuts by Year 25, especially in both pine and the unscarified mixedwood clear-cuts. Hares had girdled $66 \%$ and $48 \%$ of pine trees in scarified and unscarified pine clear-cuts, respectively, by Year 26. Girdling of conifers was not noticeable within spruce and mixedwood clear-cuts.

Immature Stand (25-50 years for Pine and Mixedwood, 30-60 years for Spruce clear-cuts)

At Year 32, in pine clear-cuts, a well stocked stand of lodgepole pine averaging 7.2 and $6.4 \mathrm{~m}$ in height was the dominant vegetative feature, in scarified and unscarified clear-cuts, respectively. Alder, poplar and willow dominated old skid roads. Average heights of pine, poplar and willow were greater in the scarified clear-cut and this was associated with a higher density of nitrogen-fixing green alder. Girdling of 25-27 year old trees by snowshoe hares was $41 \%$ higher in the scarified pine clear-cut and this was correlated with higher hare abundance (15\%), greater coniferous density (64\%) and deciduous tree/shrub density (6\%), and heights of pine, poplar and willow compared with those in the unscarified clear-cut. Mortality of 28 and $23 \%$ of pine in scarified and unscarified clear-cuts, respectively, was expected because of trees girdled more than $50 \%$. Very heavy big game use (summer and winter) of young mountain ash and alpine fir trees was preventing these species from becoming a conspicuous component of this Immature Stand.

Grass cover had declined to about one-third of that at Year 5 but was still 2-4 times greater than that in the mature pine forest. 
Similarly, forb cover had declined to almost one-half of that at Year 5.

Abundance of cervids was higher than during previous stages with deer being most abundant, then moose and lastly elk. At Year 32, big game abundance was greatest in unscarified clear-cuts except for the pine forest where abundance was similar in both clear-cuts. Deer comprised 55 and $81 \%$ of big game use in scarified and unscarified clear-cuts, respectively, with elk and then moose being next in abundance. Moose were more common in upland pine than in lowland spruce and mixedwood clear-cuts. Cover and forage conditions were optimal for big game in both pine clear-cuts.

Grouse were more abundant than during earlier stages and were higher in scarified than in unscarified clear-cuts. Only spruce grouse occurred within pine clear-cuts, while some ruffed grouse existed in the more open habitat adjacent to perimeter roads. Red squirrels were more abundant in both pine clear-cuts than during earlier stages.

A marked contrast existed between scarified and unscarified clear-cuts of the mixedwood forest at Year 32. The scarified clear-cut supported an aspen poplar overstory ( $2.5 \mathrm{~m}$ tall) with a light density of spruce and pine averaging $1.9 \mathrm{~m}$ tall. The unscarified area supported a light density of tall aspen (>10 m) that remained after logging, a lower overstory of spruce $(3.2 \mathrm{~m}$ tall) and a lower layer of aspen/willow that was taller than in the scarified clear-cut. Density and canopy cover values of conifers tall enough $(>2 \mathrm{~m}$ ) to provide minimum winter shelter were 149/ha and $25.3 \%$ in the unscarified clear-cut, which were 67 and $500 \%$ higher than those in the scarified clear-cut. For these reasons, winter cover for cervids was inadequate in scarified and only moderately adequate in unscarified clear-cuts. Superior cover conditions in the unscarified clear-cut were reflected in deer and elk use that was 6-fold greater than in the adjacent scarified block. It was also associated with a grouse abundance that was 4-fold greater than in the scarified block. The unscarified block also had a density of 23 tree snags/ha that supported several species of tree cavity-dwelling wildlife species, compared with none in the scarified block.

Differences were less pronounced in the 32 year-old spruce forest. The average height of spruce trees was 2.1 times greater in unscarified $(1.5 \mathrm{~m})$ than in scarified $(0.7 \mathrm{~m})$ clear-cuts. The density of shelter conifers ( $>2 \mathrm{~m}$ ) was 2.5 times greater, and coniferous canopy cover 5.6 times greater, in unscarified than in scarified clear-cuts. Winter shelter conditions were still inadequate even in the unscarified clear-cut as density and canopy cover values of conifers $>2 \mathrm{~m}$ tall were 
only $760 /$ ha and $3.3 \%$. Use of the unscarified clear-cut by deer and elk was 2.5 times greater than in the scarified clear-cut. Conversely, grouse were common in the scarified clear-cut during summer but absent in the unscarified clear-cut.

Aside from the above wildlife and habitat conditions associated with the four successional stages, there were several major biophysical and human land use results of significance. These can be listed as follows:

1. Unscarified clear-cuts supported higher use of big game, furbearer, insectivorous and tree cavity-dwelling wildlife than did scarified clear-cuts.

2. Negative correlations existed between winter wildlife abundance and both wind chill and animal visibility. Positive correlations existed between winter wildlife abundance and conifer tree height, and crown closure.

3. Thermal shelter and security cover were more important than forage in dictating big game use of clear-cuts during winter.

4. Adequate winter cover (thermal and security) did not occur in unscarified clear-cuts until at least $15-20$ years post logging in pine and 25-30 years in spruce and mixedwood clear-cuts. In scarified clear-cuts, this occurred at 15-20 years in pine and after 32 years in spruce and mixedwood clear-cuts.

5. Positive aspects of clear-cut logging included an increase in wildlife species characteristic of open Herb-dwarf shrub and Pole-sapling stages such as sparrows, thrushes, swallows, flycatchers and hawks, white-tailed and mule deer, elk, rodents. Cervid (deer, elk and moose) use of 17 year-old scarified and unscarified clear-cuts was 9 and 59 times greater, respectively, than in nearby mature forests.

6. Big game use of clear-cuts could have been increased further by maintaining mature, residual blocks (at least $100 \mathrm{~m}$ wide) until 15-20 years after logging in pine, $25-30$ years in unscarified and 35-40 years in scarified spruce and mixedwood clear-cuts.

7. Tree cavity-dwelling wildlife cannot be maintained in clear-cuts unless some old age-dead trees, especially aspen, are left standing following logging. A light density (24/ha) of standing snags was adequate to sustain a variety of cavity-dwelling wildlife species.

8. Black and grizzly bears avoided clear-cuts during the first 17 years. However, between Years 25 and 32, black bears were common in all clear-cuts and their use was associated with an 
abundance of insect food in the rotted stumps and logs, berries such as buffalo-berry and adequate escape cover.

9. Densities of snowshoe hares and the degree of girdling damage to conifers in clear-cuts increased directly with the density of conifers and deciduous trees and shrubs, and heights of pine and willow.

10. Although unscarified clear-cuts were more beneficial to a variety of wildilfe species than were scarified clear-cuts, results from scarification varied as a result of site-specific factors.

11. Yearlong human harassment of big game, especially elk, was a major factor in preventing big game from attaining population densities that clear-cut habitats were capable of supporting.

12. Coniferous regeneration in spruce and mixedwood unscarified clear-cuts was advanced about 5-10 years over their scarified counterparts. This was due to spruce seedlings present, but not destroyed, when unscarified clear-cuts were logged and which had a major start over spruce seedlings originating after scarification.

\subsection{MANAGEMENT IMPLICATIONS}

1. Where continuous populations of deer, elk and moose are a forest wildlife management objective, coniferous blocks at least $100 \mathrm{~m}$ wide (preferably $200 \mathrm{~m}$ ), and interspersed at distances not exceeding $200 \mathrm{~m}$ throughout the clear-cuts should be retained until clear-cuts provide adequate winter cover for cervids. This will occur about 15-20 years post-logging in pine, 25-30 years in unscarified and 35-40 years in scarified spruce and mixedwood clear-cuts.

2. In order to retain viable populations of tree cavity-dwelling wildlife in clear-cuts, some decadent or dead tree snags, especially those exceeding $25 \mathrm{~cm}$ dbh, will have to be retained. Leaving residual strips at least $100 \mathrm{~m}$ wide bordering lakes and major streams will help to maintain viable populations of tree cavitydwelling species as well as big game, grouse, furbearer and song-insectivorous birds in addition to meeting watershed needs. It will not correct this problem in areas deficient in water bodies.

3. Leaving small patches of critical wildlife cover within clear-cuts can maintain small populations of wildlife species that otherwise would disappear. It will be easier to save patches of wildlife cover 
than a scattering of individual trees when a forest is being logged by large machinery. The study indicated that patches of mature aspen within coniferous forests were especially important to many wildlife species. However, there is a need for sound quantitative information on the role of mature aspen to the welfare of bird and mammal species in the Alberta foothills.

4. The conversion of large tracts of mature coniferous forests to a variety of age classes by clear-cut logging can greatly enhance the abundance and species diversity of wildlife. However, several wildlife species such as elk have a low tolerance for human harassment and quickly abandon otherwise favorable habitat if subjected to continuous harassment, especially by vehicles. Minimizing human activities within clear-cuts should be a forest management objective, especially during the critical winter period for areas otherwise favorable for high-priority wildlife species that are sensitive to human harassment.

5. Where spruce forests are well-stocked with spruce seedlings before logging, consideration should be given to saving them during logging and post-logging. This study showed that coniferous regeneration in spruce and mixedwood unscarified clear-cuts was advanced about 5-10 years over their scarified counterparts because of numerous spruce seedlings and saplings that remained after logging. By not scarifying such areas, benefits accrue for both wood fibre and wildlife production.

6. Although adequate quantitative data was not obtained, this study showed that growth rates of pine, poplar and willow appeared to be associated with the density of nitrogen-fixing green alder. Studies in Alaska and Scandinavia have shown the importance of alder and other native nitrogen-fixing plant species in increasing soil nitrogen. Information on the importance of native nitrogen-fixing plants for enhancing both wood fibre growth and wildlife habitat should be determined before definitive forest management guidelines are developed for suppressing deciduous plant species. Some species that should be evaluated are green alder, buffalo-berry, vetch, peavine, hedysarum, locoweed and milk vetch. 


\subsection{RECOMMENDATIONS}

1. Because this study focused primarily on the effects of clear-cut logging on game species and their habitats, information on non-game species is inadequate and should be strengthened during future studies, especially for high-priority mammal and bird species expected to decline under an 80-90 year forest rotation cycle. These should include the great gray owl, pileated woodpecker, siskin, crossbill, marten, fisher and flying squirrel. A Research Advisory Board should review strengths and weakenesses of this study and determine how it can be improved, or supplemented by other studies. This long-term monitoring study with its permanent plots should be protected and continued at regular 5 or 10 year intervals throughout one forest logging cycle. Comparable results should be obtained from similar forest types logged by the newer, highly mechanized system to identify differences and similarities of floral/faunal changes during forest succession following logging.

2. The importance of native nitrogen-fixing plant species for wood fibre growth and wildlife forage/habitat enhancement should be determined.

3. The recent joint program of integrated forest/wildlife management within the Weldwood of Canada Forest Management area by this forest industry and the Alberta government is a major positive milestone that deserves the continued support of public, industry and government. 


\section{LITERATURE CITED}

American Ornithologists' Union. 1983. The A. O. U. Checklist of North American Birds, Sixth Edition. Allen Press, Inc., Lawrence, Kansas, U. S. A. 877 pp.

Banfield, A. W. F. 1977. The Mammals of Canada, Univ. of Toronto Press. $437 \mathrm{pp}$.

Becking, J. H. 1970. Plant-endophyte symbiosis in non-leguminous plants. Plant and Soll 32:611-654.

Bergen, J. D. 1971. Vertical profiles of windspeed in a pine forest. For. Sci. $17(3): 314-321$.

Berglund, E. R. and R. J. Barney. 1977. Air temperature and wind profiles in an Alaskan lowland black spruce stand. USDA For. Serv. PNW-305. Pac. N. W. For. and Range. Exp. Stn.

Canada Atmospheric Environment Service. 1981. Wind chill factor. Canada Dept of Environment - Atmospheric Environment Service, Ottawa.

Clark, J. D. 1960. Cutting practices in western forests. For. Chron. 29(3): 218-232.

Corns, I. G. W. and R. M. Annas. 1983. Ecological classification of Alberta forests and its applicaton for forest management. Proc. Comm. on high latitude silviculture. Pac. N. W. For. and Range Exp. Stn. USDA For. Serv.

Cowan, I. M., W. S. Hoar and J. Hatter. 1950. The effect of forest succession upon the quality and upon the nutritive values of woody plants used as food for moose. Can. J. Res., D., 28:249-271.

Daniel, W. W. 1978. Applied Nonparametric Statistics. Houghton Mifflin Co., Boston. 503 pp.

Dickson, J. G., R. N. Conner and J. H. Williamson. 1983. Snag retention increases bird use of a clear-cut. J. Wildl. Manage. 47(3): 799-804. 
Dumanski, J., T. M. Macyk, C. F. Veauvy and J. D. Lindsay. 1972. Soil survey and land elevation of the Hinton-Edson area, Alberta. Alta. Instit. Pedalogy Rep. No. 5-72-31

Hillman, G. R., J. M. Powell, and R. L. Bothwell. 1978. Hydrometerology of the Hinton-Edson area, Alberta, 1972-1975. Information Report NOR-X-202, Northern Forest Research Centre, Edmonton, Alberta.

Holroyd, G. L. and K. J. Van Tighem. 1983. Ecological (biophysical) land classification of Banff and Jasper National Parks. Vol. III. Part A: The wildlife inventory. Canadian Wildlife Service report to Parks Canada, Western Region. March 1983. 444 pp.

Hunt, H. M. 1976. Big game utilization of hardwood cuts in Saskatchewan. Proc. of the 12th North Amer. Moose Conf. and Workshop. March 1976. St. John's, Newfoundland. Pp. 91-126.

Jeffrey, W. W. 1970. Snow hydrology in the forest environment. In: Proc. Workshop Sem. Snow hydrology. Can. Nat. Comm. Intl. Hydrological Decade. Univ. New Brunswick. Pp. 1-19.

Jonkel, C. J. and I. M. Cowan. 1971. The black bear in the spruce-fir forest. Wildl. Monogr. 27. 55 pp.

Kelleyhouse, D. G. 1977. Habitat utilization by black bears in northern California. In: Bears - Their Biology and Management. Fourth Intl. Conf. on Bear Research and Manage., Kalispell, Montana, Feb. 1977. Bear Biology Assoc. Conf. Series No. 3. U. S. Govt. Printing Office, Wash., D. C. Pp 221-227.

Lawrence, D. B. 1958. Glaciers and vegetation in southeast Alaska. American Scientist 46:89-122.

Lindsey, F. G. and C. Meslow. 1977. Population characteristics of black bears on an island in Washington. J. Wildl. Manage. 41(3):408-212.

Lyon, L. J. and C. E. Jensen. 1980. Management implications of elk and deer use of clear-cuts in Montana. J. Wildl. Manage. 44(2):352-362. 
McCallum, B. 1984. Ecological considerations for the wildlife of the Champion Forest Management Area, Alberta. Typescript report by Beth McCallum. G. R. A. Abel Consultants for Alberta Forestry, Lands and Wildlife: Fish and Wildlife Division. 226 pp.

McNicol, J. G. and F. F. Gilbert. 1980. Late winter use of upland cutovers by moose. J. Wildl. Manage. 44(2): 363-371.

Miller, D. H. 1964. Interception processes during snowstorms. USDA For. Ser. Res. Paper PSW-18. Pac. S. W. For. Range. Exp. Stn.

Moen, A. N. 1973. Wildlife Ecology. W. H. Freeman and Co. 458 pp.

Moss, E. H. 1953. Forest Communities in northwestern Alberta. Canad. J. Bot. 31(2):212-252

1955. The Vegetation of Alberta. Bot. Rev. 21: 493-567.

1983. Flora of Alberta, 2nd edition revised by J. G. Packer. Univ. of Toronto Press.

Nietfeld, M. T. 1983. Foraging behavior of wapiti in the boreal mixed-wood forest, central Alberta. MSc. thesis, Univ. of Alta., Edmonton.

Pechanec, J.F. and G. D. Pickford. 1937. A comparison of some methods used in determining percentage utilization of range grasses. J. Agric. Res. 54(10):753-765.

Poll, D. M. 1981. Snowshoe hare population dynamics and interspecific relationships in Riding Mountain National Park during winter 1979-1980. Canadian Wildlife Service report to Parks Canada Prairie Region, Winnipeg, Manitoba, 69 pp.

Powell, J. M. and D. C. Maclver. 1976. Summer climate of the Hinton-Edson area, west-central Alberta. 1961-1970. Northern Forest Research Centre, Edmonton, Alberta. Info. Rep. NOR-X-149. 
Powell, J.M. 1977. Precipitation climatology of the Eastern Slopes area of Alberta. pp.187-204. Alberta Watershed Research Program Symposium Proceedings, 1977. Compiled by R. H. Swanson and P.A. Logan. Northern Forest Research Centre, Edmonton, Alberta. Info. Rep. NOR-X-176: 187-204.

Radvanyi, A. 1987 Snowshoe hares and forest plantations: literature review and problem analysis. Can. For. Serv., Northern Forest Research Centre Inf. Rep. NOR-X290.

Raynor, G. S. 1971. Wind and temperature structure in a coniferous forest and a contiguous field. Forest Sci. 17:351-363.

Scotter, G. W. 1964. Effects of forest fires on the winter range of barrenground caribou in northern Saskatchewan. Can. Wildl. Serv. Manage. Bull. Ser. 1. No. 18. $111 \mathrm{pp}$.

Stelfox, J. G. 1962. Effects on big game of harvesting coniferous forests in western Alberta. For. Chron. 38 (1); 94-107.

and R. G. H. Cormack. 1962. Effects of logging within the North Western Pulp and Power Co. lease area on big game range and populations. Alberta Fish and Wildlife Division., Edmonton, unpubl. rpt. 27 pp. typescript.

1963. Effects of harvesting a white spruce forest on big game range in western Alberta. M. Sc. thesis, Utah State Univ., Logan, Utah. 82 pp.

E. Telfer and G. M. Lynch. 1973. Effects of logging on wildlife. Fish and Game Sportsman Magazine. Fall 1973.

G. M. Lynch and J. R. McGillis. 1974. Effects on wildlife of harvesting a white spruce forest: Camp I, Hinton Alberta, 1956 to 1973. Typescript report to Canadian Wildlife Service, Edmonton and Alberta Fish and Wildlife and Forest Services, Edmonton. 52 pp. 
G. M. Lynch and J. R. McGillis. 1976. Effects of clearcut logging on wild ungulates in the central Alberta foothills. For. Chron. 52 (2): $65-70$.

1981. Effects on ungulates of clear cutting in Western Alberta: The first 25 years. Canadian Wildlife Service report. October 1981. $46 \mathrm{pp}$.

1983. Logging-wildlife interactions. Pp. 20-51. In: Symposium on Fish and Wildlife Resources and Economic Development. Published by the Alberta Soc. of Professional Biologists and the Alberta Dept. of Energy and Natural Resources.

1984. Effects of clear-cut logging and scarification on wildlife habitats in west central Alberta. Canadian Wildlife Service report. September 1984. 176 pp.

Stevens, D. S. 1972. Thermal energy exchange and the maintenance of homeothermy in white-tailed deer. Ph. D. diss., Cornell Univ. 231 $\mathrm{pp}$.

Strong, W. and S. Leggat. 1981. Ecoregions of Alberta. Alberta Energy and Natural Resources, Edmonton, Alberta.

Sullivan, T. P. and D. S. Sullivan. 1982. Barking damage by snowshoe hares and red squirrels in lodgepole pine stands in central British Columbia. Can. J. For. Res. 12:44-448.

Telfer, E. S. 1974. Logging as a factor in wildlife ecology in the boreal forest. For. Chron. 50(5):1-5

1978. Silviculture in the eastern deer yards. For. Chron. 54(4): 203-208

and A. Cairns. 1978. Stem breakage by moose. J. Wildl. Manage. 42(3):639-642. 
Thomas, J. W. 1979. Wildlife habitats in managed forests: the Blue Mountains of Oregon and Washington. Agric. Handbook No. 553, USDA Forest Service, Washington D. C.

R. G. Anderson, C. Maser and E. L. Bull. 1979. Snags. In: Wildilife Habitats in Managed Forests: The Blue Mountains of Oregon and Washington. Agric. Handbook No. 553, USDA Forest Service, Washington D. C.

Tomm, H. O., J. A. Beck, Jr. and R. H. Hudson. 1981. Response of wild ungulates to logging practices in Alberta. Can. J. For. Res. $11: 606-614$.

Virtanen, A. I. 1962. On the fixation of molecular nitrogen. Nature Commun. Inst. Forst Fenniae. 55(22):1-11.

Welsh, D. A. 1981. Impact on bird populations of harvesting the Boreal Mixedwood Forest. In: Boreal Mixedwood Symposium, Great Lakes Forest Research Centre, Sault Ste. Marie, Ontario, 16-18 September 1980, (eds.) R. D. Whitney and K. M. McLain. COJFRC Symposium Proceedings 0-P-9. Can. For. Serv. , Box 490, Sault Ste. Marie, Ontario.

Westworth, D. A., L. M. Brusnyk and G. R. Burns. 1984. Impact on wildlife of short-rotation management of boreal aspen stands. Unpubl. report for Canadian Forestry Service, Western \& Northern Region, Edmonton by D. A. Westworth \& Associates Ltd. Edmonton. 


\section{APPENDICES}

Appendix 1

Field Forms for Recording 1988 Forest-Wildlife Data 


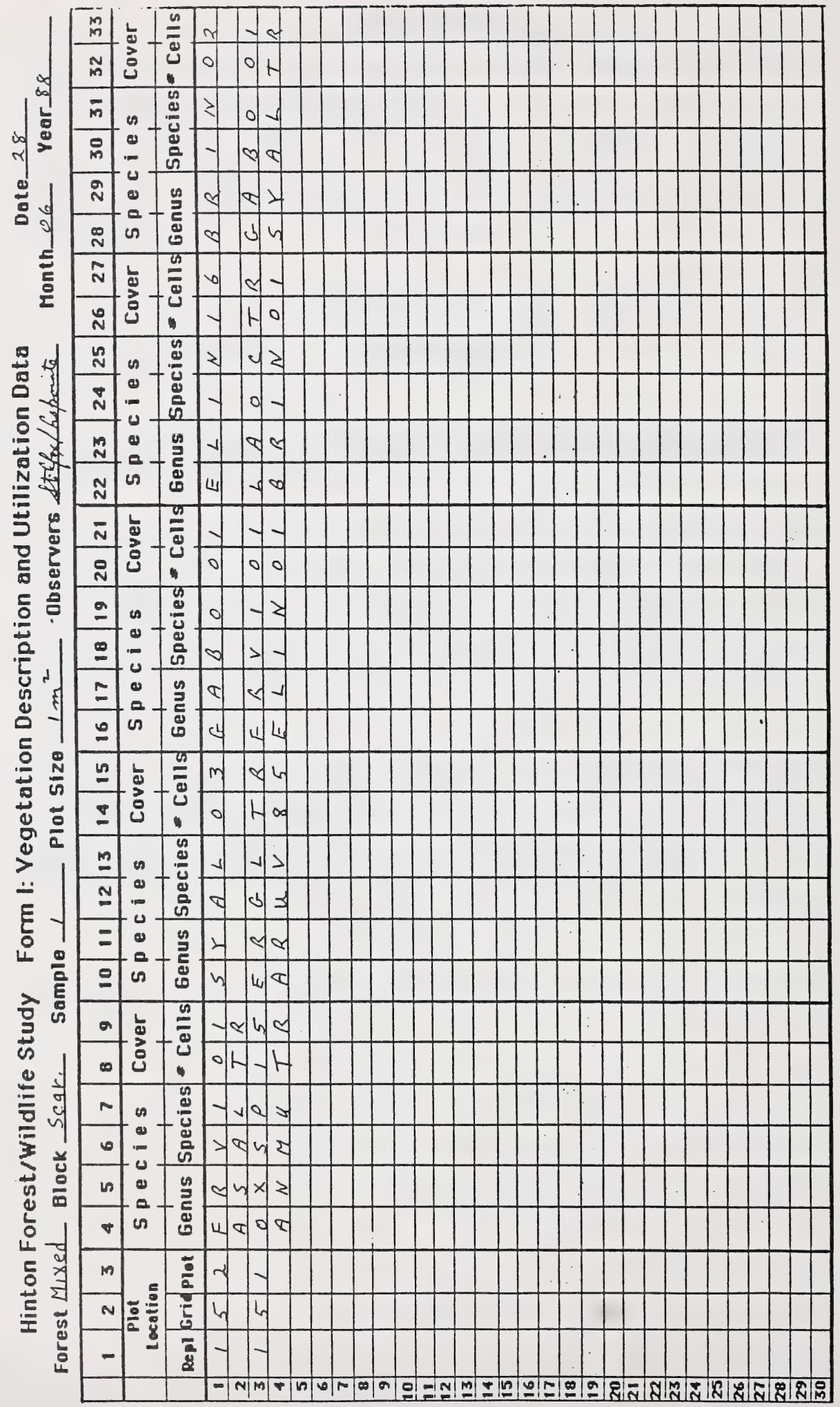




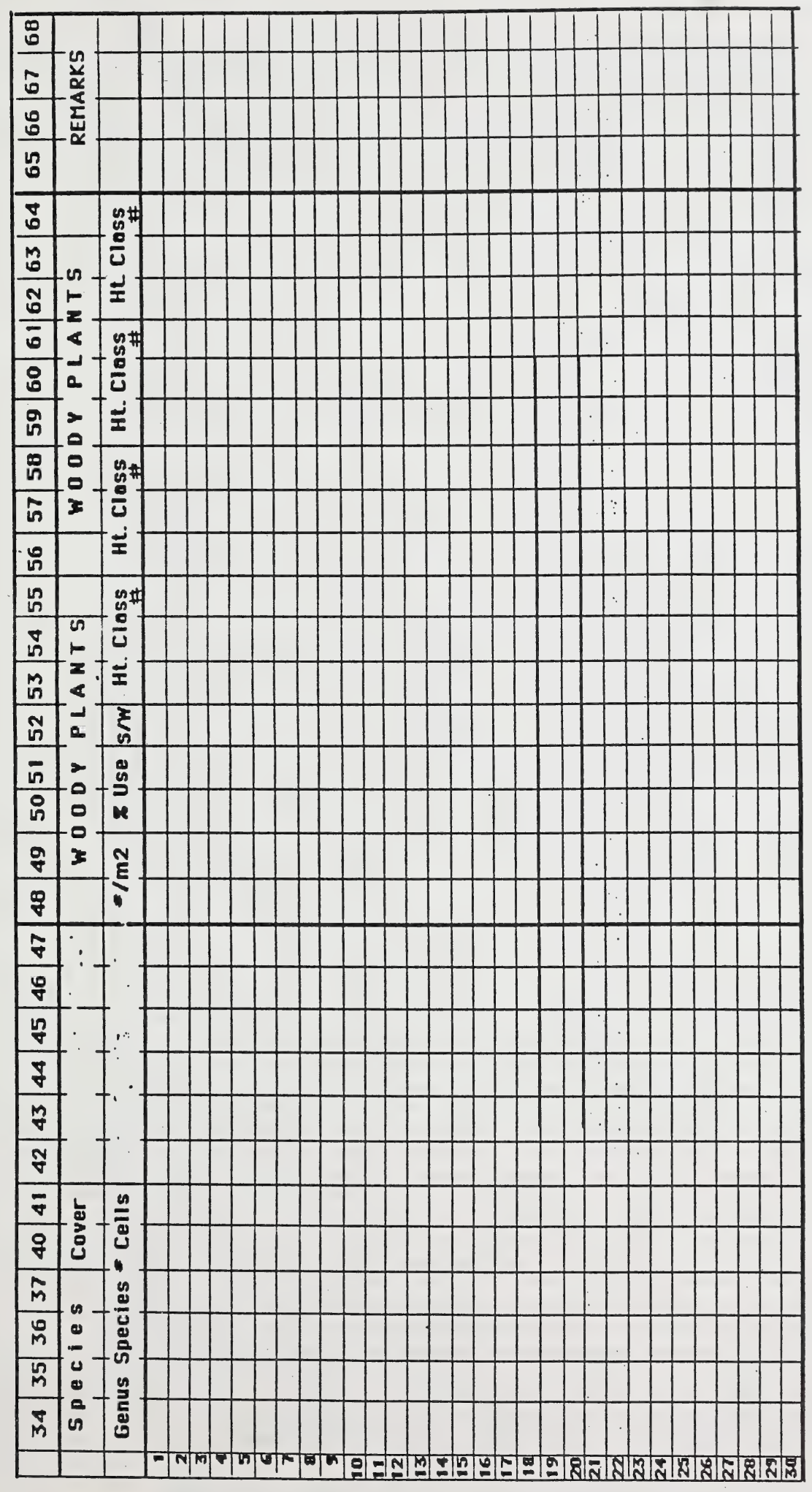




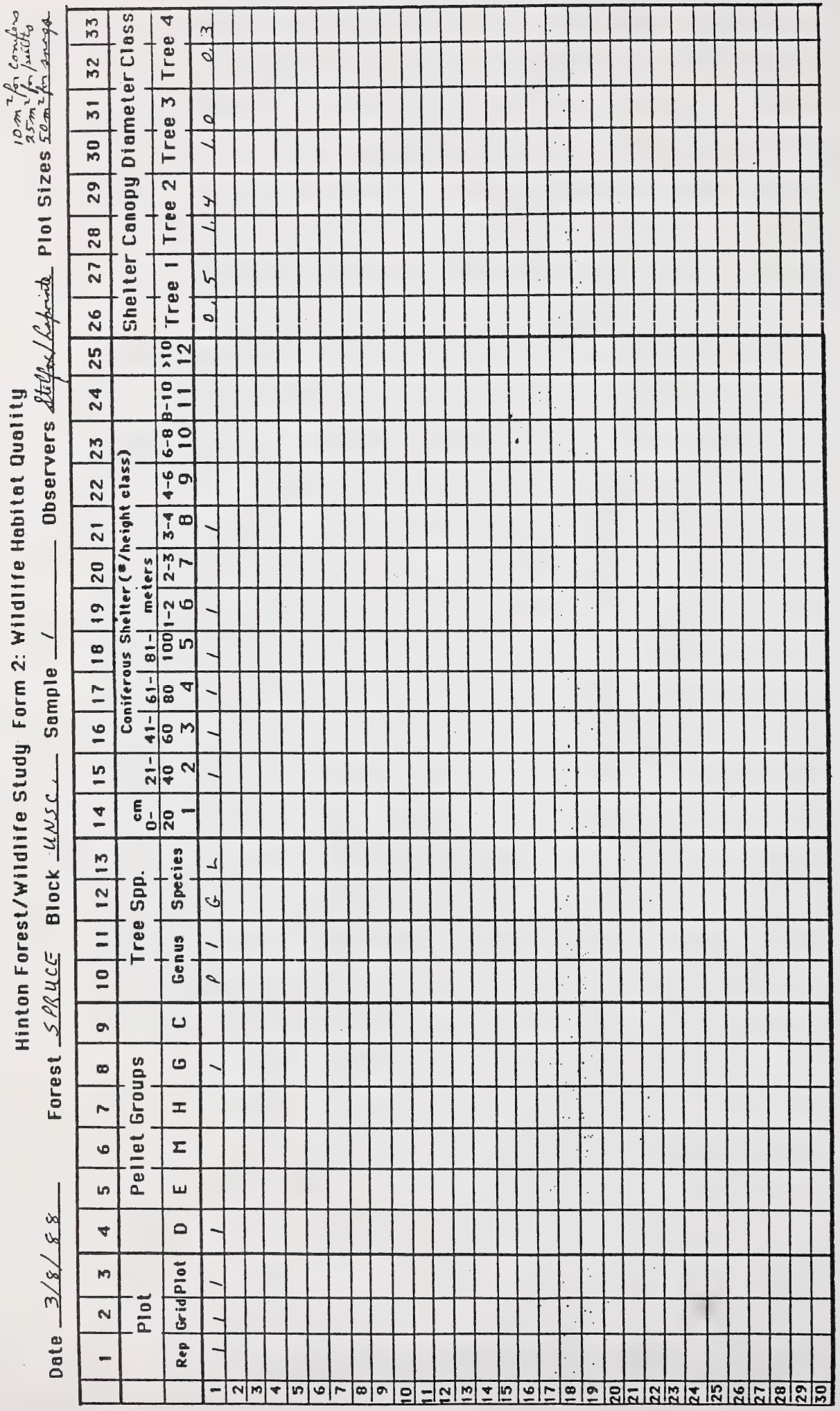




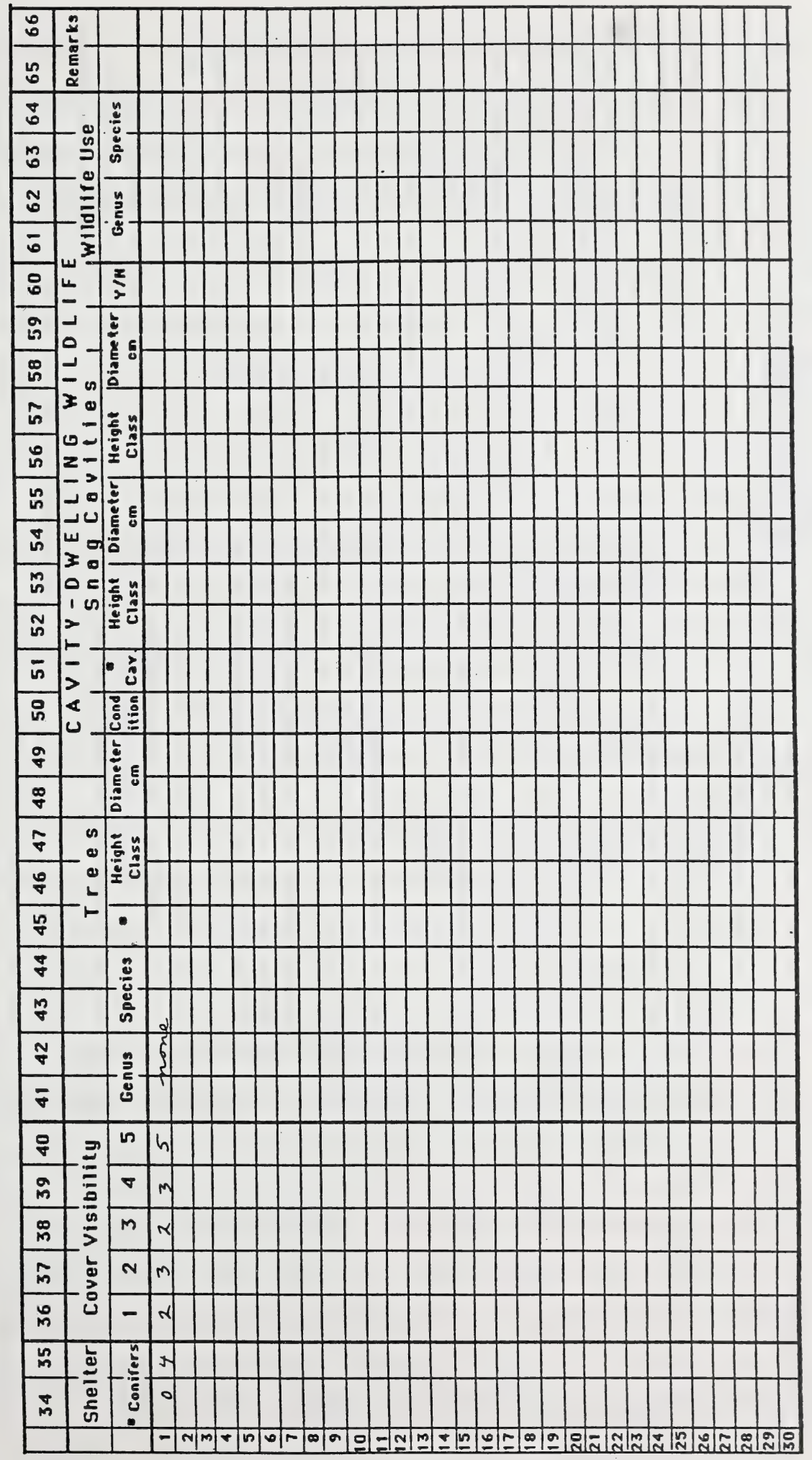




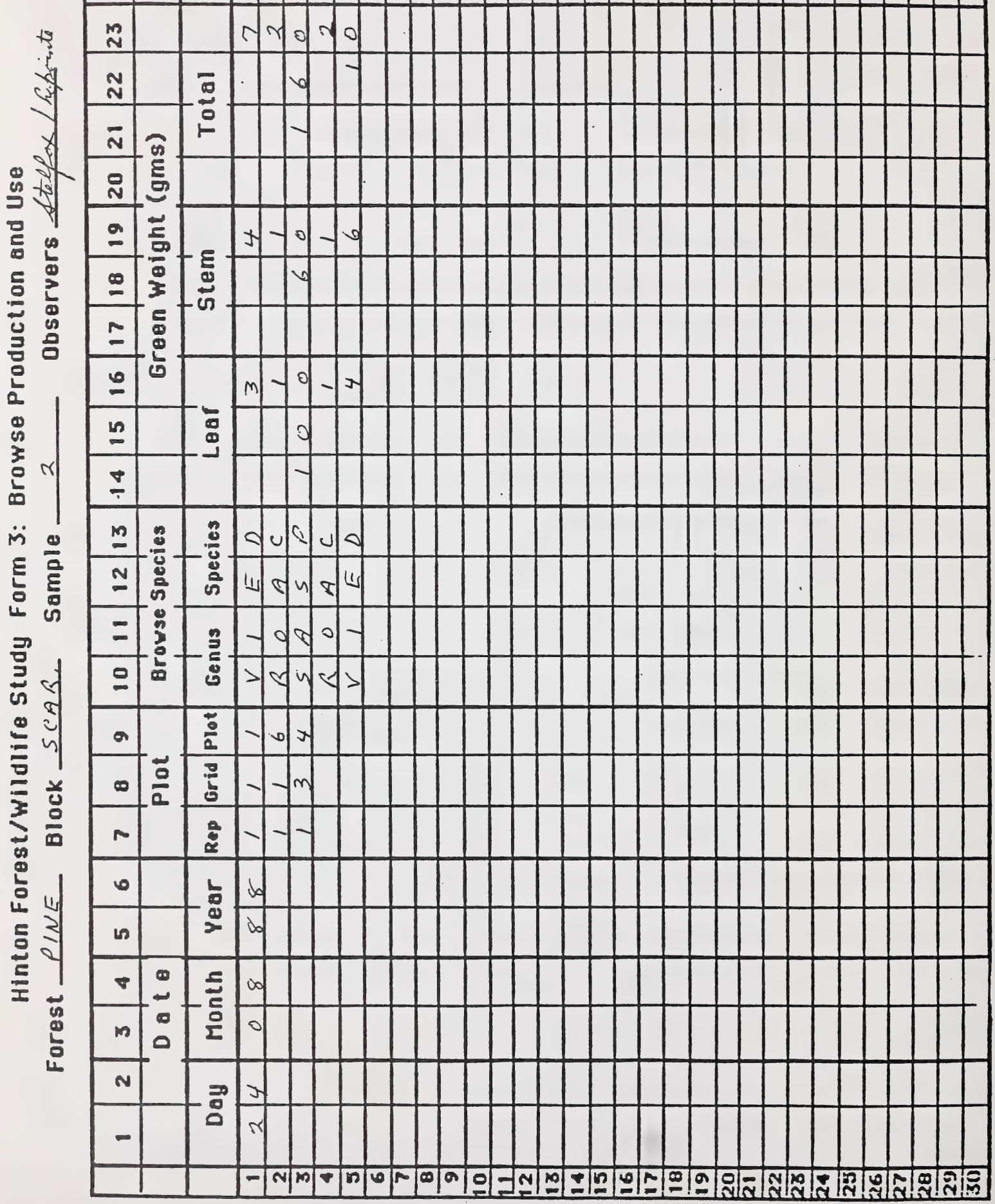




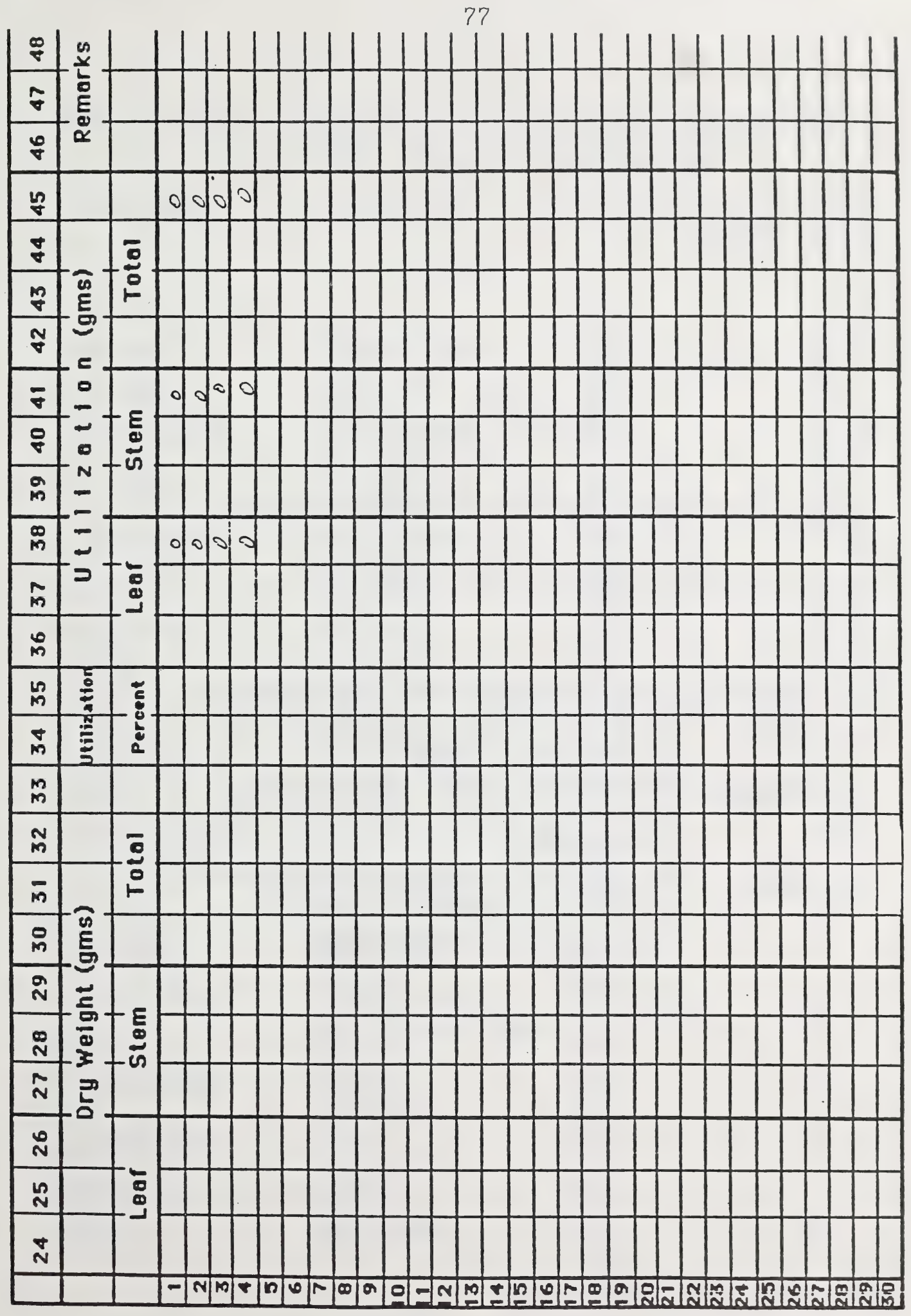




\section{Appendix 2}

Names and Symbols of Plant and Animal Species on Forest/Wildlife Plots: 1956-1988

Common and Scientific Names Follow These References:

Plants: The Flora of Alberta, 2nd edition, 1983. by

E. H. Moss and J. G. Packer.

Mammals: The Mammals of Canada. 1974 by A. W. F. Banfield. National Museum of Canada. Univ. of Toronto Press.

Birds: The American Ornithologist's Union Checklist of North American Birds, Sixth Edition.

Allen Press, Inc. Lawrence, Kansas. 
NAMES AND SYMBOLS FOR PLANT SPECIES ON HINTON FOREST/WILDLIFE PLOTS 1956-1988 (after Flora of Alberta, Moss, 1983).

SCIENTIFIC NAME

Achillea millifolium

Actaea rubra

Agoseris glauca

Alyssum murale

Anaphalis margaritacea

Androsace chamaejasme

Androsace spp.

Anemone multifida

A. parviflora

Antennaria pulcherrima

Aquileja brevistyla

Aralia nudicaulis

Arnica spp.

Aster conspicuus

A. ciliolatus

A. sibiricus

Aster spp.

Astragalus alpinus

A. drummondii

A. frigidus/americanus

A. striatus

Botrychium boreale/lunaria

Braya richardsonii/humilus

Campanula rotundifolia

Castilleja miniata

Cerastium spp.

Chenopodium album

Comandra pallida

Cornus canadensis

Cypripedium calceolus

C. passerinum

Delphinium glaucus

Disporum trachycarpum

Dodecatheon radicatum

Draba sp.

Epilobium angustifolium

Equisetum arvense

Equisetum spp.

Erigeron caespitosus

E. glabellus

E. ochroleucus
COMMON NAME

FORBS

Common Yarrow

Red and White baneberry

False Dandelion

Alyssum

Pearly Everlasting

Sweet-scented Androsace

Fairy Candelabra

Cut-leaved Anemone

Anemone

Showy Everlasting

Blue Columbine

Wild Sasparilla

Arnica

Showy Aster

Lindley's Aster

Low Aster

Aster

Alpine Milk Vetch

Drummond's Vetch

American Milk Vetch

Milk Vetch

Moon Wort

Braya

Harebell

Indian Paint-brush

Mouse-eared Chickweed

Lamb's quarter

Bastard Toad-flax

Bunchberry

Yellow Lady's Slipper

Sparrow's Egg Lady's Slipper

Tall Larkspur

Fairy Bells

Shooting Star

Whitlow Grass

Fireweed

Field Horsetall

Horsetail

Tufted Fleabane

Smooth Fleabane

Fleabane
SYMBOL

LOCATION Months

SP Pi Mi* in Bloom

\begin{tabular}{|c|c|c|c|c|c|}
\hline$A C M I$ & $\sqrt{ }$ & & $\sqrt{ }$ & Jun & Jul \\
\hline AC RU & & $\sqrt{ }$ & & Jun & \\
\hline $\begin{array}{l}A G G L \\
A L M U\end{array}$ & $\sqrt{ }$ & $\sqrt{ }$ & $\sqrt{ }$ & May & Jun \\
\hline AN MA & & & $\sqrt{ }$ & & Jul \\
\hline $\begin{array}{l}\text { AN CH } \\
\text { AN SP }\end{array}$ & $\sqrt{ }$ & & & May & Jun \\
\hline AN MU & $\checkmark$ & & $\sqrt{ }$ & May & Jun \\
\hline AN PA & $\sqrt{ }$ & & & May & Jun \\
\hline AN PU & $\sqrt{ }$ & & & & Aug \\
\hline$A Q B R$ & $\sqrt{ }$ & & $\sqrt{ }$ & Jun & \\
\hline AR NU & & $\sqrt{ }$ & & May & Jun \\
\hline AR SP & $\sqrt{ }$ & $\sqrt{ }$ & $\sqrt{ }$ & Jun & Jul \\
\hline AS CO & $\sqrt{ }$ & & $\sqrt{ }$ & Jul & Aug \\
\hline $\mathrm{ASCl}$ & $\sqrt{ }$ & & $\sqrt{ }$ & Jul & Aug \\
\hline AS SI & $\checkmark$ & & & Jul & Aug \\
\hline AS SP & $\sqrt{ }$ & & & & Aug \\
\hline $\begin{array}{l}\text { AS AL } \\
\text { AS DR }\end{array}$ & $\sqrt{ }$ & & $\sqrt{ }$ & May & Jun \\
\hline AS FR & $\sqrt{ }$ & & $\sqrt{ }$ & Jun & Jul \\
\hline AS ST & $\sqrt{ }$ & & & Jun & Jul \\
\hline BOBO & $\sqrt{ }$ & & $\sqrt{ }$ & Jun & Jul \\
\hline BR RI & & & & & \\
\hline CA RO & $\sqrt{ }$ & $\checkmark$ & $\sqrt{ }$ & Jun & Jul \\
\hline CA MI & $\sqrt{ }$ & $\sqrt{ }$ & $\sqrt{ }$ & Jun & Jul \\
\hline CE SP & $\sqrt{ }$ & & $\sqrt{ }$ & Jun & \\
\hline
\end{tabular}

CH AL

COPA

COCA

CY CA

CY PA

DE GL

DI TR

DORA

DR SP

EP AN

EQ AR

EQSP

ER CA

ER GL

ER OC

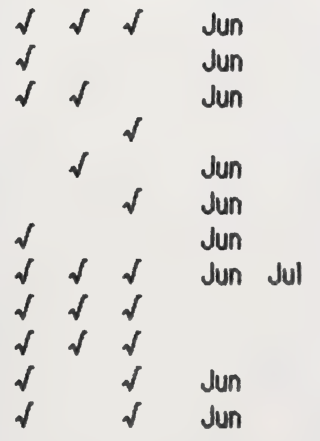


E philadelphicus

Fraparia vesca/virginiana

Galium boreale

G. trifiorum

Gentianella amarella

G. crinata

Geocaulon lividum

Geranium bicknellii

Geum rivale

Goadyera repens

Habenaria hyperborea

H. obtusata

$H$. viridus

Hedysarum alpinum

H. mackenzii/boreale

Heracleum lanatum

Heuchera flabellifolia/parvifolia

Hieraceum umbellatum

Lathyrus ochroleucus

Lilium philadelphicum

Linnaea borealis

Luzula parvifiora

Maianthemum canadense

Matricaria matricarioides

Mertensia paniculata

Mitella nuda

Moneses uniflora

Orchis rotundifolia

Orthilia secunda

Oxycoccus microcarpus

Oxytropis splendens

0. monticola

Parnassus fimbreata

Pedicularis bracteosa

Petasites 5pp.

Petasites palmatus

Plantago major

Polygonum viviparum

Potentilla anserina

$P$ norvegica

Pulsatilla occidentalis

Pulsatilla 5pp.

Pyrola asarifolia

Pyrola spp.

Ranunculus acris

Rubus acaulis

$R$. pubescens

R. stigosus

Senecio palustris

S. pseudaureus

Senecio spp.

Sisyrinchium montanum

Smilacina racemosa
Fleabane

Wild Strawberry

Northern Bedstraw

Sweet-scented Bedstraw

Felwort

Fringed Gentian

Bastard Toad-flax

Crane's Bill

Purple Avens

Rattling Plantain

Northern Green Bog Orchid

Blunt-leaved Orchid

Bracted Orchid

Hedysarum

Indian Potatoe

Cow Parsnip

Alum-root

Narrow-leaved Hawkweed

Wild Pea

Western Wood Lily

Twin flower

Wood Rush

Wild Lily-of-the-Valley

Pineapple Weed

Tall Mertensia

Bishop s-cap

One-flowered Wintergreen

Round-leaved Orchid

One-sided Wintergreen

Small Bog Cranberry

Showy Loco-weed

Late Yellow Loco-weed

Grass-of Parnassus

Bracted Lousewort

Coltsfoot

Palamate-leaved Coltsfoot

Common Plantain

Bistort

Silverweed

Rough Cinquefoil

Chalice-flower

Anemone

Common Pink Wintergreen

Wintergreen

Tall Buttercup

Dwarf Raspberry

Dewberry

Wild Raspberry

Marsh Ragwort

Thin-leaved Ragwort

Groundsel

Blue-eyed Grass

False Solomon's-seal
ER PH

FRVI

GA BO

GA TR

GE AM

GE CR

GE LI

GE BI

GE RI

GORE

HA HY

HA OB

HAVI

HE AL

HE MA

HE LN

HE FL

HI UM

LAOC

$\triangle I \mathrm{PH}$

LI BO

LUPA

MA CA

MA MA

ME PA

MI NU

MO UN

OR RO

OR SE

OXMI

OX SP

OX MO

PAFI

PE BR

PE SP

PE PA

PL MA

POVI

POAN

PONO

PUOC

PU SP

PY AS

PY SP

RA AC

RU AC

RU PU

RU ST

SE PA

SE PS

SE SP

SI MO

SMRA

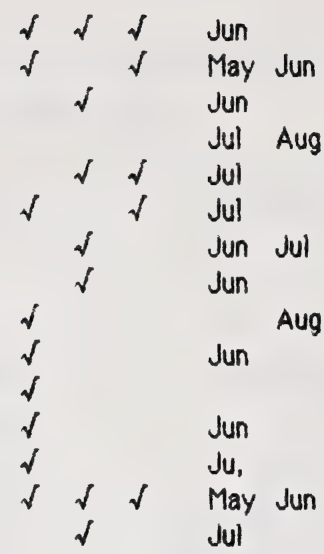

$\begin{array}{lllll} & & \sqrt{ } & \text { Jun Jul } \\ \sqrt{ } & \sqrt{ } & \sqrt{ } & \text { Jun } \\ \sqrt{ } & \sqrt{ } & \sqrt{ } & \text { Jun } \\ \sqrt{ } & & & \text { Jul Aug } \\ & \sqrt{ } & & \text { Jun }\end{array}$

$\sqrt{ } \quad \sqrt{ }$ Jun $\sqrt{ }$

Jun

Jun

Jun

Jul

Jul

Jun

Jul

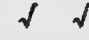

Jun

Jun Jul

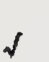

$$
\sqrt{ } \sqrt{ }
$$

Jul

Jul

Jun

Jun

Jun

Jun

Jun

Jun

$\sqrt{ }$ Jun 
S. stellata

Solidago spp.

S. decumbens/spathulata

S. gigantea

Sonchus arvensis

Spiraea lucida/betulifolia

Spiranthus romanzoffiana

Stellaria longipes

S. longifolia

Streptopus amplexifolius

Symphoricarpus albus

Taraxacum officianale

Thalictrum venulosum

Tofieldia glutinosa

Trifolium pratense

T. repens

Veronica SpD.

Vicia americana

Viola renifolia

Viola spp.

Zizia cordata

Zygadenus elegans

Unknown Forb
Star-flowered Solomon's seal

Goldenrod

Mountain Goldenrod

Tall Smooth Goldenrod

Sow thistle

White Meadowsweet

Ladies'-tresses

Long-leaved Chickweed

Long-stalked Chickweed

Twisted-stalk

Snowberry

Dandelion

Veiny Meadow Rue

Sticky Asphosel

Common Red Clover

White Dutch Clover

Speedwell

American Vetch

Kidney-leaved Violet

Violet

Heart-leaved Alexanders

Smooth Camas

Forb
SM ST*

SO SP

SODE

SO GI

SO AR

SPLU

SP RO

ST LO

ST LF

ST AM

SY AL

TA OF

THVE

TR GL

TR PR

TR RE

VE SP

VI AM

VI RE

VISP

ZI CO

ZY EL

UNFO
Jun

Jul Aug

Jun Jul

Jul Aug

Jul Aug

Jun

Jul

$\sqrt{ } \quad \begin{array}{ll}\text { Jun } \\ \text { Jun }\end{array}$

$\sqrt{ } \sqrt{ }$ May Jun

June

$\sqrt{1} \quad$ Jul

$\sqrt{ } \sqrt{ } \sqrt{ }$ Jun

$\sqrt{ }$ Jun

May

$\sqrt{ } \begin{array}{ll}\text { Jun } \\ \text { Jun }\end{array}$

$\sqrt{2}$ Jun
4

- $S P=$ Spruce $\quad P i=$ Pine $M i=$ Mixedwood

- Persicaria natans is Polygonum viviparum

- Virtually all Petasites SPD. in 1988 was P. palmatus

In Camp 9 this is actually Smilacina racemosa

- Includes both Viola canadense and V. renifolia 


\section{GRAMINOIDS (Grasses and Sedges)}

Agropyron spicatum

A. subsecundum

A. trachycaulum Agrostis alba

A. scabra

Bromus inermis

Bromus spp.

Calamagrostis canadensis

C. montanensis

Carex aurea

C. capillaria

C. eburnea

Carex spp.
AG SP

AG SU

AG TR

$A G$ AL

AG SC

BR IN

BR SP

CA CA

CA MO

CA AU

CA CP

CAEB

CA SP
Deschampsia caespitosa

Elymus innovatus

Festuca rubra

Festuca spp.

Glyceria striata

Juncus balticus

Juncus spp.

Phleum pratense

$P$. alpinum

Poa palustris

P. spp.

P. pratense

Unknown grass
DE CA

EL IN

FE RU

FE SP

GL ST

JU BA

JU SP

PH PR

PH AL

POPA

PO SP

POPR

UN GR

\section{TREES AND SHRUBS (Browse plants)}

Abies lasiocarpa
Alnus crispa
Amelanchier alnifolia
Arctostaphylos uva-ursi
Betula glandulosa
B. papyrifera
B. occidentalis
Cornus stolonifera
Juniperus communis
J. horizontalis
Lonicera dioica
L. involucrata
Picea glauca
Pinus contorta
Populus balsamifera
P. tremuloides
$A B$ LA
$A L C R$
AM AL
ARUV*
BE GL
BEPA
$B E \propto C$
COST
JU CO*
JU HO
LODI
LOIN
PI GL
PICO
POBA
POBA

Potentilla fruticosa
Prunus pensylvanica
Ribes oxycanthoides
R. triste
Rosa acicularis
Rubus acaulis
R. pubescens
R. strigosus/idaeus
Salix spp.
Sambucus racemosa
Shepherdia canadensis
Sorbus scopulina
Symphoricarpus albus
Vaccinium caespitosum
Viburnum edule
Unknown Browse

POFR

PR PE

RI OX

RI TR

RO AC

RUAC

RUPU *

RU ST

SA SP

SA RA

SHCA

SO SC

SY AL*

VACA*

VIED

UN BR

* These species were included in forbs category for purposes of density/cover analysis because of decumbent growth form.

\section{LICHENS, MOSSES AND FERNS}

\section{LICHEMS}

Peltigera apthosa

Cladonia spp.
PE AP

CL SP

\section{MOSSES}

Hylocomium splendens

Pleurozium schreberi
HY SP

PL SC

\section{FERNS}

Gymnocarpium dryopteris

GY DR 


\begin{tabular}{|c|c|c|c|}
\hline Common Name & Scientific Name & Common Name & Scientific Name \\
\hline \multicolumn{4}{|c|}{ MAMMALS } \\
\hline Snowshoe Hare & Lepus americanus & Elk (Wapiti) & Cervus elaphus \\
\hline Red-backed Vole & Clethrionomys agoperi & Moose & Alces alces \\
\hline Heather Vole & Phenacomys intermedius & Mule Deer & Odocoileus hemionus \\
\hline Meadow Vole & Microtus Dennsylvanicus & White-tailed Deer & Odecolleus viroinianus \\
\hline Deer Mouse & Peromyscus maniculatus & Caribou & Banoifer tarandus \\
\hline Coyote & Canis latrans & Cougar & Eelis concolor \\
\hline Red Fox & Vuloes vuloes & Black Bear & Ursus americanus \\
\hline Grey Wolf & Canis lupus & Grizzly Bear & Ursus arctos \\
\hline Canada Lynx & Lynx canadensis & Marten & Martes americana \\
\hline Least Weasel & Mustela nivalis & Fisher & Martes pennanti \\
\hline Ermine & Mustela erminea & Red Squirrel & Tamiasciurus hudsonicus \\
\hline Least Chipmunk & Eutamias minimus & N. Flying Squirrel & Glaucomys sabrinus \\
\hline Big Brown Bat & Entesicus fuscus & & \\
\hline
\end{tabular}

\begin{tabular}{|c|c|c|c|}
\hline \multirow[b]{2}{*}{ Spruce Grouse } & \multicolumn{2}{|c|}{ BIRDS } & \multirow[b]{2}{*}{ Bucephala clanqula } \\
\hline & Dendragopus canadensis & Common Goldeneye & \\
\hline Blue Grouse & Dendragoous obscurus & Bufflehead & Bucephala albeola \\
\hline Ruffed Grouse & Bonasa umbellus & Hooded Merganser & Lophodytes cucullatus \\
\hline Sharp-tailed Grouse & Iymoanunchus ohasianellus & Gray Jay & Perisoreus canadensis \\
\hline American Kestrel & Falce soarverius & Black-billed Magpie & Picapica \\
\hline Merlin & Falco columbarius & Common Raven & Corvus corax \\
\hline Swainson's Hawk & Buteo swainsonii & Swainson's Thrush & Hylocichla ustulato \\
\hline Northern Goshawk & Accioiter oentilis & Hermit Thrush & Hylocichla quttata \\
\hline Black-capped Chickadee & Parus atricaoillus & American Robin & Iurdus mioratorius \\
\hline Boreal Chickadee & Parus hudsenicus & Cedar Waxwing & Bombycilla cedorus \\
\hline Red-breasted Nuthatch & Sitta canadensis & European Starling & Hurnus vuloaris \\
\hline White-breasted Nuthatch & Sitta carolinensis & Warbling Vireo & Vireo oilvus \\
\hline Tree Swallow & Iachycineta bicolor & Red-eyed Vireo & Vireo ollvaceus \\
\hline Violet-green Swallow & Tachycineta thalassing & Orange-crowned Warbler & Vermivora celata \\
\hline House wren & Iroolodytes aedon & Vellow-rumped Warbler & Dendroica cononata \\
\hline Golden-crowned Kinglet & Ruoulus satrana & Magnolia Warbler & Dendroics maonolia \\
\hline Ruby-crowned Kinglet & Requlus calendula & Black-and-White Warbler & - Miniotill ta varia \\
\hline Mountain Blueblrd & Sialla curricoides & Yellow Warbler & Dendroica petechla \\
\hline Fox Sparrow & Passerella iliaca & Red Crossbill & Loxia curvirosta \\
\hline Song Sparrow & Melospiza melodia & Purple Finch & Carpodacus ouroureus \\
\hline Lincoln's Sparrow & Melosoiza lincolnii & Pine Siskin & Carduelis oinus \\
\hline White-crowned Sparrow & Zonotrichia leucoohrys & Northern Flicker & Colaptes auratus \\
\hline White-throated Sparrow & Zonotrichia albicollis & Downy Woodpecker & Picoides pubeceus \\
\hline American Tree Sparrow & Spizella arborea & Hairy Woodpecker & Picoides villosus \\
\hline Chipping Sparrow & Soizella oasserina & Three-toed Woodpecker & Picoides tridactulus \\
\hline Vesper Sparrow & Pooecetes oramineus & Yellow-bellied Sapsucker & Sphyrapicus varius \\
\hline Dark-eyed Junco & Junco hyemalis & Say's Phoebe & Sayornis saya \\
\hline Common Loon & Gavia immer & Alder Flycatcher & Emoidonax alnorum \\
\hline Northern Saw-whet Owl & Aeoolius acadicus & Willow Flycatcher & Empidonax traillii \\
\hline Boreal Owl & Aegolius funereus & Yellow-bellied Flycatche & rEmoidonax flaviventria \\
\hline Great Gray Owl & Strix nebulosa & Western Wood-Pewee & Contoous sordidulus \\
\hline Common Nighthawk & Chordeiles minor & Rufous Hummingbird & Selasphorus rufus \\
\hline Killdeer & Charadrius vociferus & Belted Kingfisher & Cervle alcyon \\
\hline Solitary Sandplper & Iringa solitaria & & \\
\hline Upland Sandpiper & Bartramia lonaicauda & & \\
\hline Common Snipe & & & \\
\hline
\end{tabular}




\section{Appendix 3}

\section{Statistical Analyses of 1988 Forest-Wildlife Data}

Comparison of values among three forest types (Mixedwood, Pine, Spruce) using combined scarified and unscarified data for the following comparisons:

1. Percent Cover (Grasses and Forbs)

2. Deciduous Browse Density

3. Tree Snag Density

4. Coniferous and Deciduous Tree Cover (Shelter and Security Cover)

5. Coniferous Density

6. Wildlife Abundance (Pellet Groups/Ha) 
Table 1. Random block design analysis (SPSS $-x$ Release for IBM/MTS) of differences in foliage cover of grasses and forbs, density of deciduous browse and snags among three forest types* (mixedwood, pine, spruce) 32 years after logging.

\begin{tabular}{lcccc}
\hline & MIXEDWOOD & PINE & SPRUCE & STANDARD ERROR \\
& $(X)$ & $(Y)$ & $(Z)$ & OF THE MEAN \\
FORBS ( 8 cover) & $18.73 . a^{* *}$ & $25.22 \mathrm{a}$ & $26.75 \mathrm{a}$ & \pm 1.653 \\
GRASSES ( 8 cover) & $16.97 \mathrm{a}$ & $19.53 \mathrm{a}$ & $19.67 \mathrm{a}$ & \pm 2.895 \\
BROWSE (Density/Ha) & $46425 \mathrm{a}$ & $39050 \mathrm{a}$ & $45625 \mathrm{a}$ & \pm 6111.073
\end{tabular}

PLANT SPECIES***

AR UV

Aster sp.

Astrag Sp./HE SP/OX SP

EP AN

FR VI

$\mathrm{JUCO}+\mathrm{JUHO}$

LIBO

$V I A M+L A O C$

$B R I N+B R S P$

$C A C A+C A M O$

CAREX

EL IN

POPLAR

ROSE

SA SP

15-30 cm diam.

$31+$ diam

Total snags

Cavities

Poplar

Willow

Rose

Total browse
GRASS, FORB AND MAT-LIKE SHRUB COVER

$\begin{array}{cccc}6.33 \mathrm{a} & 0.21 \mathrm{~b} & 12.47 \mathrm{c} & \pm 0.779 \\ 0.90 \mathrm{a} & 2.04 \mathrm{~b} & 1.01 \mathrm{a} & \pm 0.260 \\ 0.84 \mathrm{a} & 0.0 \mathrm{a} & 3.11 \mathrm{~b} & \pm 0.152 \\ 0.49 \mathrm{a} & 7.99 \mathrm{~b} & 0.18 \mathrm{a} & \pm 0.570 \\ 2.46 \mathrm{a} & 0.54 \mathrm{a} & 0.69 \mathrm{a} & \pm 0.258 \\ 0.0 \mathrm{a} & 0.0 \mathrm{a} & 2.62 \mathrm{a} & \pm 0.560 \\ 0.42 \mathrm{a} & 2.18 \mathrm{~b} & 2.05 \mathrm{~b} & \pm 0.107 \\ 1.65 \mathrm{a} & 0.09 \mathrm{~b} & 0.00 \mathrm{~b} & \pm 0.167 \\ 5.07 \mathrm{a} & 0.01 \mathrm{~b} & 2.26 \mathrm{~b} & \pm 0.456 \\ 0.0 \mathrm{a} & 8.70 \mathrm{~b} & 0.22 \mathrm{a} & \pm 0.138 \\ 0.48 \mathrm{a} & 0.04 \mathrm{a} & 3.37 \mathrm{a} & \pm 0.915 \\ 11.03 \mathrm{a} & 10.72 \mathrm{a} & 13.39 \mathrm{a} & \pm 3.752\end{array}$

\section{DECIDUOUS TREE DENSITIES}

$3400.00 a$
$29300.00 a$
$500.00 a$

$2250.00 a$
$23375.00 a$
$975.00 a$

3950.00 a

$\pm 425.245$

32575.00 a

$+9881.559$

$4850.00 \mathrm{~b}$

$\pm 262.599$

\section{SNAGS}

13.00 a
3.33 a
16.33 a
10.33 a

$11.00 a$
$4.00 a$
$15.00 a$
$4.00 a$

$9.67 \mathrm{a}$

2.008

11.67 a

10.33 a

$\pm 4.290$

$\pm 0.943$

$\pm 3.706$

$\pm 4.320$

\section{DECIDUOUS BROWSE}

$\begin{array}{rrrr}161.50 \mathrm{a} & 173.50 \mathrm{a} & 252.50 \mathrm{a} & \pm 65.962 \\ 7.50 \mathrm{a} & 118.50 \mathrm{a} & 403.50 \mathrm{a} & \pm 4.041 \\ 60.50 \mathrm{a} & 53.50 \mathrm{a} & 122.50 \mathrm{a} & \pm 16.258 \\ 292.50 \mathrm{a} & 1093.00 \mathrm{a} & 877.00 \mathrm{a} & \pm 175.810\end{array}$

\footnotetext{
* Scarified and unscarified data was combined for each for est; mature data was not used. $\mathrm{Xa} \mathrm{Ya}_{\mathrm{Z}} \mathrm{Z}=$ not significantly different from each other.

$X a Y a Z b=X$ and $Y$ are significantly different from $Z$.

$X a Y b Z c=X, Y$, and $Z$ are all significantly different from each other.

See appendix 2 for common and scientific names of these symbols.
} 
Table 2. Random block design analysis (SPSS- $x$ Release for IBM/MTS) of differences in coniferous, deciduous, and total tree cover; canopy closure (shelter) and security (hiding) cover* among three forest types, 32 years after logging.

\begin{tabular}{lrrrr}
\hline & MIXEDWOOD & PINE & \multicolumn{1}{c}{ SPRUCE } & SE OF $\overline{\mathrm{X}}$ \\
\multicolumn{5}{c}{ CONIFEROUS COVER } \\
Ht. classes $1-7$ & $1904.67 \mathrm{a}$ & $156.50 \mathrm{a}$ & $6585.00 \mathrm{a}$ & \pm 1229.999 \\
Ht. classes 8 & $281.67 \mathrm{a}$ & $71.50 \mathrm{a}$ & $126.00 \mathrm{a}$ & \pm 72.276 \\
Ht. classes $9-10$ & $604.33 \mathrm{a}$ & $607.25 \mathrm{a}$ & $147.50 \mathrm{a}$ & \pm 157.476 \\
Ht. classes $11-12$ & $264.33 \mathrm{a}$ & $482.00 \mathrm{a}$ & $34.00 \mathrm{a}$ & \pm 107.979 \\
Ht. classes $8-12$ & $1150.33 \mathrm{a}$ & $1160.75 \mathrm{a}$ & $307.50 \mathrm{a}$ & \pm 331.604 \\
Total Coniferous & $3055.00 \mathrm{a}$ & $1317.25 \mathrm{a}$ & $6892.50 \mathrm{a}$ & \pm 1252.051
\end{tabular}

\section{DECIDUOUS COVER}

Ht. classes $1-7$

H. classes 8

Ht. classes $9-10$

Ht. classes $11-12$

Ht. classes $8-12$

Total Deciduous

H. classes $1-7$
Ht. classes 8
H. classes $9-10$
H. classes $11-12$
Ht. classes $8-12$
Total Cover

Ht. classes $1-7$

H. classes 8

Ht. classes $9-10$

Ht. classes $11-12$

Ht. classes $8-12$

Total Canopy Cover

Tatal Security

Spruce
Pine
ToTal Conifers

$\begin{array}{rrr}48916.66 \text { a } & 37375.00 a & 44550.00 a \\ 300.00 \mathrm{~b} & 800.00 \mathrm{a} & 525.00 \mathrm{a} b \\ 516.67 \mathrm{a} & 750.00 \mathrm{a} & 550.00 \mathrm{a} \\ 316.67 \mathrm{a} & 125.00 \mathrm{a} & 0.00 \mathrm{a} \\ 1133.33 \mathrm{a} & 1675.00 \mathrm{a} & 1075.00 \mathrm{a} \\ 50050.00 \mathrm{a} & 39050.00 \mathrm{a} & 45625.00 \mathrm{a}\end{array}$

$\pm 5498.452$

$\pm 65.670$

$\pm 149.16$

$\pm 101.550$

$\pm 206.761$

$\pm 5691.527$

\section{TOTAL TREE COVER}

$\begin{array}{rrrr}50821.33 \text { a } & 37531.50 \mathrm{a} & 51135.00 \mathrm{a} & \pm 4622.219 \\ 581.67 \mathrm{a} & 871.50 \mathrm{a} & 651.00 \mathrm{a} & \pm 126.269 \\ 1121.00 \mathrm{a} & 1357.25 \mathrm{a} & 697.50 \mathrm{a} & \pm 201.440 \\ 581.00 \mathrm{a} & 607.00 \mathrm{a} & 34.00 \mathrm{a} & \pm 204.973 \\ 2283.67 \mathrm{a} & 2835.75 \mathrm{a} & 1382.50 \mathrm{a} & \pm 498.331 \\ 53105.00 \mathrm{a} & 40367.25 \mathrm{a} & 52517.50 \mathrm{a} & \pm 5020.853\end{array}$

\section{CANOPY CLOSURE (SHELTER)}

$\begin{array}{rrrr}2253.29 a & 329.89 a & 1368.23 \mathrm{a} & \pm 416.863 \\ 474.45 \mathrm{a} & 233.28 \mathrm{a} & 48.23 \mathrm{a} & \pm 185.543 \\ 982.59 \mathrm{a} & 2313.80 \mathrm{a} & 53.58 \mathrm{a} & \pm 464.031 \\ 450.28 \mathrm{a} & 1591.26 \mathrm{a} & 19.18 \mathrm{a} & \pm 312.717 \\ 1907.32 \mathrm{a} & 4138.34 \mathrm{a} & 121.00 \mathrm{a} & \pm 944.385 \\ 4160.55 \mathrm{a} & 4468.19 \mathrm{a} & 1489.20 \mathrm{a} & \pm 1306.273 \\ 277.60 \mathrm{a} & 4468.19 \mathrm{a} & 317.20 \mathrm{a} & \pm 51.053\end{array}$

\section{CONIFEROUS DENSITY}

$\begin{array}{rrrr}2761.67 \mathrm{a} & 145.00 \mathrm{a} & 6892.50 \mathrm{a} & \pm 1383.529 \\ 291.33 \mathrm{a} & 1168.00 \mathrm{~b} & 0.0 \mathrm{a} & \pm 170.662 \\ 3053.00 \mathrm{a} & 1317.25 \mathrm{a} & 6892.50 \mathrm{a} & \pm 1252.002\end{array}$

\begin{tabular}{lccc} 
& \multicolumn{2}{c}{ SECURITY (Hiding) } & COVER \\
Scarified & Unscarified & Mature \\
Mixed & $59.25 \mathrm{a}$ & $125.80 \mathrm{~b}$ & $105.53 \mathrm{~b}$ \\
Pine & 128.30 & $131.90 \mathrm{a}$ & - \\
Spruce & $99.43 \mathrm{a}$ & $112.03 \mathrm{~b}$ & $104.20 \mathrm{C}$
\end{tabular}

\section{Mature \\ $105.53 \mathrm{~b}$ \\ $104.20 \mathrm{C}$}

Scarified and unscar ified values were combined and comparisons made among forest types except for Security (hiding) cover where comparisons were also among scarified, unscar ifed and mature as well as among three forest types. 
Table 3. Random block design analysis (SPSS- $x$ Release for IBM/MTS) of differences in abundance of deer, elk, moose, snowshoe hare, grouse, and coyote among three forest types, (mixedwood, pine, spruce) 32 years after logging.

\section{\begin{tabular}{lllll}
\hline WILDLIFE SPECIES MIXEDWOOD & PINE SPRUCE & S.E OF $\bar{x}$
\end{tabular}}

\begin{tabular}{llllll}
\hline \multicolumn{6}{l}{ WILDLIFE PELLET GROUPS/Ha } \\
Deer & - Summer & $10.00 \mathrm{a}$ & $31.00 \mathrm{a}$ & $38.00 \mathrm{a}$ & \pm 9.534 \\
& - Winter & $14.00 \mathrm{a}$ & $63.00 \mathrm{a}$ & $164.00 \mathrm{~b}$ & \pm 23.372 \\
& - Total & $24.00 \mathrm{a}$ & $94.00 \mathrm{a}$ & $202.00 \mathrm{~b}$ & \pm 23.642 \\
Elk & - Summer & $0.0 \mathrm{a}$ & $0.0 \mathrm{a}$ & $17.00 \mathrm{a}$ & \pm 3.381 \\
& - Winter & $1.33 \mathrm{a}$ & $2.00 \mathrm{a}$ & $22.00 \mathrm{~b}$ & \pm 2.503 \\
& - Total & $1.33 \mathrm{a}$ & $2.00 \mathrm{a}$ & $39.00 \mathrm{~b}$ & \pm 5.462 \\
Moose & - Summer & $-(0)$ & $-10)$ & $-(0)$ & - \\
& - Winter & $0.0 \mathrm{a}$ & $24.00 \mathrm{~b}$ & $0.0 \mathrm{a}$ & \pm 2.898 \\
& - Total & $0.0 \mathrm{a}$ & $24.00 \mathrm{~b}$ & $0.0 \mathrm{a}$ & \pm 2.898 \\
Hares & - Total & $2448.00 \mathrm{a}$ & $1003.00 \mathrm{a}$ & $34.0 \mathrm{a}$ & \pm 1279.236 \\
Grouse & - Total & $57.33 \mathrm{a}$ & $182.00 \mathrm{a}$ & $11.00 \mathrm{a}$ & \pm 46.441 \\
Coyote & - Total & $-(0)$ & $-(0)$ & $-(0)$ & - \\
\hline
\end{tabular}


MTS ANOVA Analyses of 1988 Data After Pooling Plot Data Into Five, 20 Plot Blocks of Data

\section{Specifics of Data Input}

1) Security (escape) Cover data (Vegetative Profile Board) - Data lumped into 3 height classes:

Ht. $1=$ Classes 1 and $2=<1 \mathrm{~m}$

Ht. $2=$ Classes 3 and $4=1-2 m$

Ht. $3=$ Class $5 \quad=2-2.5 \mathrm{~m}$

2) Snag Density - Density of dead and decadent tree snags of 2 diameters at breast height (dbh), namely: $15-30 \mathrm{~cm} \mathrm{dbh,}>30 \mathrm{~cm} \mathrm{dbh}$.

Also density of cavities per hectare.

3) Coniferous Canopy Closure (Thermal/Shelter cover) - Data lumped into 5 height classes:

Ht. $1=\leq 3 \mathrm{~m}=$ Height classes 1-7;

Ht. $2=3-4 m=$ Height classes 8 ;

Ht. $3=4-8 m=$ Height classes 9 and 10 ;

Ht. $4=8-10+m=$ Height classes 11 and 12;

Ht. $5=3-10+m=$ Height classes 8 and 12 .

4) Deciduous Tree/Shrub Density - total, poplar, willow, rose, others. Data lumped into the same 5 height classes as shown above.

5) Forest Types - Forest $1=$ Mixedwood, Forest $2=$ Pine, Forest $3=$ Spruce .

6) Scar vs Scar = Scarified Sample I vs Scarified Sample 2; Unsc vs Unsc = Unscarified Sample I vs Unscarified Sample 2; Scar vs Unscar $=$ Scarified Ave vs Unscarified Ave.

7) Mean 1 Mean 2 Mean 3
a $b$
a Mean 2 is different from Means 1 and 2;

$a b \quad a$
b Mean 1 in not different from 1 or 2, but Means 2 and 3 are different from each other;
a b c All are different from each other. 
Table 4 a. ANOVA of big game security (escape) cover in 32 year-old clear-cuts.

\begin{tabular}{|c|c|c|c|c|c|c|c|c|c|}
\hline Clear-cut & Height & $M \perp \times E D W C$ & 000 & P & $N$ & $E$ & $S F$ & $\triangle R U$ & $E$ \\
\hline Types & Classes & Mean 1 Mean 2 & $\begin{array}{l}\text { Sig."* } \\
\text { Level }\end{array}$ & Mean 1 & Mean 2 & $\begin{array}{l}\text { Sig. } \\
\text { Level }\end{array}$ & Mean 1 & Mean 2 & $\begin{array}{l}\text { Sig. } \\
\text { Level }\end{array}$ \\
\hline Scar vs Scar & $\begin{array}{l}\text { Total } \\
\text { Ht. } 1 \\
\text { Ht. } 2 \\
\text { Ht. } 3\end{array}$ & 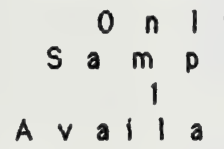 & 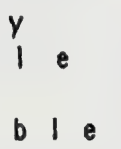 & $\begin{array}{l}74.68 \\
83.00 \\
70.34 \\
66.66\end{array}$ & $\begin{array}{l}79.46 \\
85.98 \\
75.34 \\
74.68\end{array}$ & $\begin{array}{l}0.540 \\
0.408 \\
0.624 \\
0.495\end{array}$ & $\begin{array}{l}62.26 \\
78.32 \\
55.68 \\
41.32\end{array}$ & $\begin{array}{l}57.06 \\
66.34 \\
51.68 \\
49.32\end{array}$ & $\begin{array}{l}0.599 \\
0.137 \\
0.680 \\
0.513\end{array}$ \\
\hline Unsc vs Unsc & $\begin{array}{l}\text { Total } \\
\text { Ht. } 1 \\
\text { Ht. } 2 \\
\text { Ht. } 3\end{array}$ & 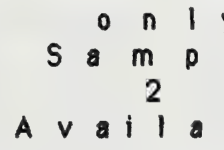 & $\begin{array}{lll}y & \\
1 & e \\
b & 1 & e\end{array}$ & $\begin{array}{l}79.06 \\
79.00 \\
79.00 \\
79.34\end{array}$ & $\begin{array}{l}79.20 \\
82.34 \\
77.00 \\
77.34\end{array}$ & $\begin{array}{l}0.976 \\
0.532 \\
0.737 \\
0.737\end{array}$ & $\begin{array}{l}69.58 \\
78.34 \\
66.32 \\
58.66\end{array}$ & $\begin{array}{l}64.80 \\
78.66 \\
57.00 \\
52.68\end{array}$ & $\begin{array}{l}0.417 \\
0.938 \\
0.235 \\
0.470\end{array}$ \\
\hline Scar vs unsc & $\begin{array}{l}\text { Total } \\
\text { Ht. } 1 \\
\text { Ht. } 2 \\
\text { Ht. } 3\end{array}$ & $\begin{array}{ll}35.60 & 73.48 \\
43.68 & 76.74 \\
29.32 & 71.34 \\
32.00 & 71.20\end{array}$ & $\begin{array}{l}0.00^{*} \\
0.01^{\star} \\
0.01^{*} \\
0.01^{*}\end{array}$ & $\begin{array}{l}77.07 \\
84.49 \\
72.84 \\
70.67\end{array}$ & $\begin{array}{l}79.13 \\
80.67 \\
78.00 \\
78.34\end{array}$ & $\begin{array}{l}0.480 \\
0.230 \\
0.196 \\
0.205\end{array}$ & $\begin{array}{l}59.66 \\
72.33 \\
54.18 \\
45.32\end{array}$ & $\begin{array}{l}67.19 \\
78.50 \\
61.66 \\
55.67\end{array}$ & $\begin{array}{l}0.167 \\
0.411 \\
0.293 \\
0.174\end{array}$ \\
\hline
\end{tabular}

Table $4 \mathrm{~b}$. ANOVA of big game security cover values among three forest type clear-cuts (32 year-old).

\begin{tabular}{|c|c|c|c|c|c|}
\hline \multirow{2}{*}{$\begin{array}{l}\text { Clear-cut } \\
\text { Types }\end{array}$} & \multirow{2}{*}{$\begin{array}{l}\text { Height } \\
\text { Classes }\end{array}$} & \multicolumn{2}{|c|}{ MIXEDWOOD } & \multicolumn{2}{|l|}{ SPRUCE } \\
\hline & & Mean 1 & Mean 2 & Mean 2 & Sig. Level \\
\hline \multirow[t]{3}{*}{ Scarified } & $\begin{array}{l}\text { Total } \\
\text { Ht. } 1\end{array}$ & $\begin{array}{l}35.60 \\
43.68\end{array}$ & $\begin{array}{l}77.07 \text { b } \\
84.49\end{array}$ & $\begin{array}{l}59.66 \text { c } \\
72.33\end{array}$ & $\begin{array}{l}0.0091^{*} \\
0.0948\end{array}$ \\
\hline & Ht. 2 & 29.32 a & $72.84 \mathrm{~b}$ & $54.18 c$ & $0.0075^{*}$ \\
\hline & $\mathrm{Ht} .3$ & $32.00 \mathrm{a}$ & $70.67 \mathrm{~b}$ & $45.32 \mathrm{c}$ & $0.0119^{*}$ \\
\hline \multirow[t]{3}{*}{ Unscarified } & $\begin{array}{l}\text { Total } \\
\text { Ht. } 1\end{array}$ & $\begin{array}{l}73.48 \mathrm{ab} \\
76.74\end{array}$ & $\begin{array}{l}79.13 \\
80.67\end{array}$ & $\begin{array}{l}67.19 b \\
78.50\end{array}$ & $\begin{array}{l}0.0088^{\#} \\
0.2133\end{array}$ \\
\hline & Ht. 2 & $71.34 \mathrm{ab}$ & $78.00 a$ & $61.66 \mathrm{~b}$ & $0.0246^{*}$ \\
\hline & $\mathrm{Ht}, 3$ & 71.20 & 78.34 & $55.67 b$ & $0.0031^{*}$ \\
\hline
\end{tabular}

* the means are significantly different at 958 level $(p<.05)$

$\sqrt{H t} 1=\langle 1 \mathrm{~m}$, Ht $2=1-2 \mathrm{~m}$, Ht $3=2-2.5 \mathrm{~m}$ 
Table 5a. ANOVA of snag densities within each forest.

\begin{tabular}{|c|c|c|c|c|c|c|c|c|c|c|}
\hline Clear-cut & $\mathrm{dbh}^{\sqrt{ }} \mathrm{M}$ & $M \perp \times E$ & DWO & OD & $P$ & $1 \mathrm{~N}$ & $E$ & $S P$ & $R \cup C$ & $E$ \\
\hline Types & (cm) $M$ & Mean 1 & Mean 2 & $\begin{array}{l}\text { Sig. } \\
\text { Level }\end{array}$ & Mean 1 & Mean 2 & $\begin{array}{l}\text { Sig. } \\
\text { Level }\end{array}$ & Mean 1 & Mean 2 & $\begin{array}{l}\text { Sig. } \\
\text { Level }\end{array}$ \\
\hline Scar vs Scar & $\begin{array}{l}\text { Total } \\
15-30 \\
31+ \\
\text { Cavities }\end{array}$ & $A \vee$ & $\begin{array}{l}0 \cap 1 \text { Y } \\
a m p \mid \\
1 \\
\mid 1 a\end{array}$ & & $\begin{array}{l}0 \\
0 \\
0 \\
0\end{array}$ & $\begin{array}{r}30.00 \\
24.00 \\
6.00 \\
2.00\end{array}$ & $\begin{array}{l}0.05^{*} \\
0.10 \\
0.17 \\
0.35\end{array}$ & $\begin{array}{l}0 \\
0 \\
0 \\
0\end{array}$ & $\begin{array}{l}0 \\
0 \\
0 \\
0\end{array}$ & $\begin{array}{l}1.00 \\
1.00 \\
1.00 \\
1.00\end{array}$ \\
\hline Unsc vs Unsc & $\begin{array}{l}\text { Total } \\
15-30 \\
31+ \\
\text { Cavities }\end{array}$ & $\begin{array}{l}24.00 \\
14.00 \\
10.00 \\
\quad 12.00\end{array}$ & $\begin{array}{r}22.00 \\
8.00 \\
14.00 \\
22.00\end{array}$ & $\begin{array}{l}0.817 \\
0.305 \\
0.608 \\
0.419\end{array}$ & $\begin{array}{r}32.00 \\
20.00 \\
12.00 \\
8.00\end{array}$ & $\begin{array}{r}54.00 \\
42.00 \\
12.00 \\
6.00\end{array}$ & $\begin{array}{l}0.140 \\
0.084 \\
1.000 \\
0.545\end{array}$ & $\begin{array}{r}32.00 \\
28.00 \\
4.00 \\
8.00\end{array}$ & $\begin{array}{r}12.00 \\
10.00 \\
2.00 \\
6.00\end{array}$ & $\begin{array}{l}0.030 \\
0.070 \\
0.545 \\
0.724\end{array}$ \\
\hline ar vs unsc & $\begin{array}{l}\text { Total } \\
15-30 \\
31+ \\
\text { Cavities }\end{array}$ & $\begin{array}{l}0 \\
0 \\
0 \\
-\end{array}$ & $\begin{array}{c}23.00 \\
11.00 \\
12.00 \\
-\end{array}$ & $\begin{array}{l}0.001^{*} \\
0.016^{*} \\
0.037^{*} \\
-\end{array}$ & $\begin{array}{r}15.00 \\
12.00 \\
3.00 \\
-\end{array}$ & $\begin{array}{c}43.00 \\
31.00 \\
12.00 \\
-\end{array}$ & $\begin{array}{l}0.271 \\
0.364 \\
0.096 \\
-\end{array}$ & $\begin{array}{l}0 \\
0 \\
0 \\
-\end{array}$ & $\begin{array}{r}22.00 \\
19.00 \\
3.00 \\
-\end{array}$ & $\begin{array}{l}0.159 \\
0.169 \\
0.096 \\
-\end{array}$ \\
\hline
\end{tabular}

Table 5b. ANOVA of snag densities among the forests.

\begin{tabular}{llcccc}
\hline $\begin{array}{l}\text { Clear-cut } \\
\text { Types }\end{array}$ & $\begin{array}{c}\text { dbh } \\
(\mathrm{cm})\end{array}$ & \begin{tabular}{c} 
MIXEOWOOD \\
\cline { 3 - 6 } Mean 1
\end{tabular} & $\begin{array}{c}\text { PINE } \\
\text { Mean 2 }\end{array}$ & $\begin{array}{c}\text { SPRUCE } \\
\text { Mean 3 }\end{array}$ & Sig. Level \\
\hline Scarified & Total & 0 & 15.00 & 0 & 0.3081 \\
& $15-30$ & 0 & 12.00 & 0 & 0.3081 \\
& $31+$ & 0 & 3.00 & 0 & 0.3081 \\
& Cavities & 0 & 1.00 & 0 & 0.3081 \\
\hline Unscarified & Total & 23.00 & 43.00 & 22.00 & 0.2935 \\
& $15-30$ & 11.00 & 31.00 & 19.00 & 0.3643 \\
& $31+$ & 12.00 a & 12.00 a & $3.00 \mathrm{~b}$ & $0.0247^{*}$ \\
& Cavities & 17.00 & 7.00 & 7.00 & 0.1548 \\
\hline
\end{tabular}

* the means are significantly different

$\checkmark$ diameter $(\mathrm{cm})$ of snag at breast height 
Table 6a. ANOVA of canopy closure within each 32 year-old forest type.

\begin{tabular}{|c|c|c|c|c|c|c|c|c|c|c|}
\hline \multirow{2}{*}{$\begin{array}{l}\text { Clear-cut } \\
\text { Types }\end{array}$} & \multirow{2}{*}{$\begin{array}{l}\text { Height } \\
\text { Classes }\end{array}$} & \multicolumn{3}{|c|}{ MIXEDWOOD } & \multirow{2}{*}{$\frac{P}{\text { Mean } 1}$} & \multirow{2}{*}{$\frac{1 N}{M e a n ~} 2$} & \multirow{2}{*}{ 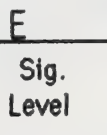 } & \multicolumn{3}{|c|}{$S P R \cup C E$} \\
\hline & & Mean & 1 Mean 2 & $\begin{array}{c}\text { Sig. } \\
\text { Level }\end{array}$ & & & & Mean 1 & Mean 2 & $\begin{array}{l}\text { Sig. } \\
\text { Level }\end{array}$ \\
\hline $\begin{array}{l}\text { Scar vs Scar } \\
<3 \mathrm{~m} \\
3-4 \mathrm{~m} \\
4-8 \mathrm{~m} \\
8-10 \mathrm{~m} \\
3-10+m\end{array}$ & $\begin{array}{l}\text { Total } \\
\text { Ht. } 1 \\
\text { Ht. } 2 \\
\text { Ht. } 3 \\
\text { Ht. } 4 \text { A } \\
\text { Ht. } 5\end{array}$ & 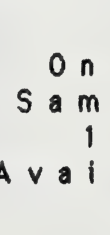 & $\begin{array}{l}1 y \\
01 \text { e }\end{array}$ & & $\begin{array}{r}5183.6 \\
208.4 \\
282.7 \\
2447.6 \\
2245.0 \\
4975.2\end{array}$ & $\begin{array}{r}3889.6 \\
87.0 \\
142.2 \\
2526.9 \\
1133.5 \\
3802.6\end{array}$ & $\begin{array}{l}0.406 \\
0.107 \\
0.058 \\
0.932 \\
0.154 \\
0.436\end{array}$ & $\begin{array}{c}1866.3 \\
1830.2 \\
10.9 \\
25.3 \\
0 \\
36.2\end{array}$ & $\begin{array}{r}858.7 \\
844.3 \\
5.7 \\
8.5 \\
0 \\
14.2\end{array}$ & $\begin{array}{l}0.006^{*} \\
0.021^{*} \\
0.417 \\
0.186 \\
1.000 \\
0.239\end{array}$ \\
\hline $\begin{array}{l}\text { Unsc vs Unsc } \\
<3 \mathrm{~m} \\
3-4 \mathrm{~m} \\
4-8 \mathrm{~m} \\
8-10 \mathrm{~m} \\
3-10+m\end{array}$ & $\begin{array}{l}\text { Total } \\
\text { Ht. } 1 \\
\text { Ht. } 2 \\
\text { Ht. } 3 \\
\text { Ht. } 4 \\
\text { Ht. } 5\end{array}$ & $\begin{array}{r}1403.6 \\
984.3 \\
75.9 \\
211.0 \\
132.4 \\
419.3\end{array}$ & $\begin{array}{r}6295.1 \\
2886.7 \\
827.3 \\
1669.7 \\
911.4 \\
3401.8\end{array}$ & $\begin{array}{l}0.002^{*} \\
0.007^{*} \\
0.009^{*} \\
0.002^{*} \\
0.045^{*} \\
0.008^{*}\end{array}$ & $\begin{array}{c}3761.7 \\
544.8 \\
288.6 \\
2214.3 \\
714.1 \\
3216.9\end{array}$ & $\begin{array}{r}4132.4 \\
343.9 \\
206.5 \\
1840.6 \\
1743.4 \\
3790.5\end{array}$ & $\begin{array}{l}0.394 \\
0.339 \\
0.310 \\
0.194 \\
0.022^{*} \\
0.299\end{array}$ & $\begin{array}{r}1598.5 \\
1249.8 \\
137.3 \\
147.3 \\
71.1 \\
348.6\end{array}$ & $\begin{array}{r}2285.2 \\
2082.1 \\
96.8 \\
88.6 \\
17.8 \\
203.1\end{array}$ & $\begin{array}{l}0.247 \\
0.124 \\
0.470 \\
0.270 \\
0.059 \\
0.244\end{array}$ \\
\hline $\begin{array}{l}\text { Scar vs Unsc } \\
<3 \mathrm{~m}\end{array}$ & $\begin{array}{l}\text { Total } \\
\text { H. } 1\end{array}$ & $\begin{array}{l}1893.4 \\
1210.5\end{array}$ & $\begin{array}{l}3849.4 \\
1935.5\end{array}$ & $\begin{array}{l}0.080 \\
0.273\end{array}$ & $\begin{array}{r}4536.6 \\
147.7\end{array}$ & $\begin{array}{r}3947.1 \\
444.4\end{array}$ & $\begin{array}{l}0.473 \\
0.127\end{array}$ & $\begin{array}{l}1362.5 \\
1337.3\end{array}$ & $\begin{array}{l}1941.8 \\
1665.9\end{array}$ & $\begin{array}{l}0.442 \\
0.661\end{array}$ \\
\hline $3-4 m$ & Ht. 2 & 83.5 & 451.6 & $0.036^{*}$ & 212.5 & 247.6 & 0.708 & 8.3 & 117.0 & $0.034^{*}$ \\
\hline $4-8 m$ & Ht. 3 & 233.4 & 940.4 & $0.031^{*}$ & 2487.2 & 2027.4 & 0.138 & 16.9 & 118.0 & 0.081 \\
\hline $8-10 m$ & Ht. 4 & 56.6 & 521.9 & & 1689.2 & 1228.7 & 0.605 & 0 & 44.5 & 0.237 \\
\hline $3-10+m$ & Ht. 5 & 373.8 & 1910.6 & $0.028^{*}$ & 4388.9 & 3503.7 & 0.308 & 25.2 & 275.9 & 0.076 \\
\hline
\end{tabular}

Table 6b. ANOVA of canopy closure of 32 year-old clear-cuts among three forest types.

\begin{tabular}{|c|c|c|c|c|c|}
\hline Clear-cut & Height & MIXEDWOOD & $P \perp N E$ & SPRUCE & \\
\hline Types & Classes & Mean 1 & Mean 2 & Mean 3 & Sig. Level \\
\hline $\begin{array}{l}\text { Scarified } \\
<3 \mathrm{~m} \\
3-4 \mathrm{~m} \\
4-8 \mathrm{~m} \\
8-10 \mathrm{~m} \\
3-10+m\end{array}$ & $\begin{array}{l}\text { Total } \\
\text { Ht. } 1 \\
\text { Ht. } 2 \\
\text { Ht. } 3 \\
\text { Ht. } 4 \\
\text { Ht. } 5\end{array}$ & $\begin{array}{r}1893.4 \\
1210.5 \\
83.5 \\
233.4 \\
56.6 \\
373.8\end{array}$ & $\begin{array}{c}4536.6 \text { b } \\
147.7 \\
212.4 \text { a } \\
2487.2 \text { b } \\
1689.2 \text { a } \\
4388.9 \text { b }\end{array}$ & $\begin{array}{c}1362.5 \\
1337.3 \\
8.3 \\
16.9 \mathrm{c} \\
0 \\
25.2\end{array}$ & $\begin{array}{l}0.0178^{*} \\
0.0608 \\
0.0379 \\
0.000^{*} \\
0.0337 \\
0.0028^{*}\end{array}$ \\
\hline $\begin{array}{l}\text { Unscarified } \\
<3 \mathrm{~m} \\
3-4 \mathrm{~m} \\
4-8 \mathrm{~m} \\
8-10 \mathrm{~m} \\
3-10+\mathrm{m}\end{array}$ & $\begin{array}{l}\text { Total } \\
\text { Ht. } 1 \\
\text { Ht. } 2 \\
\text { Ht. } 3 \\
\text { Ht. } 4 \\
\text { Ht. } 5\end{array}$ & $\begin{array}{r}3849.3 \\
1935.5 \\
451.6 \\
940.4 \\
521.9 \\
1910.5\end{array}$ & $\begin{array}{r}3947.0 \\
444.4 \\
247.5 \\
2027.4 \\
1228.7 \\
3503.7\end{array}$ & $\begin{array}{r}1941.8 \\
1665.9 \\
117.0 \\
118.0 \\
44.5 \\
275.9\end{array}$ & $\begin{array}{l}0.5930 \\
0.3149 \\
0.6056 \\
0.1149 \\
0.2252 \\
0.1704\end{array}$ \\
\hline
\end{tabular}

* the means are significantly different 
Table 7a. ANOVA of conifer density (thermal shelter) within each forest.

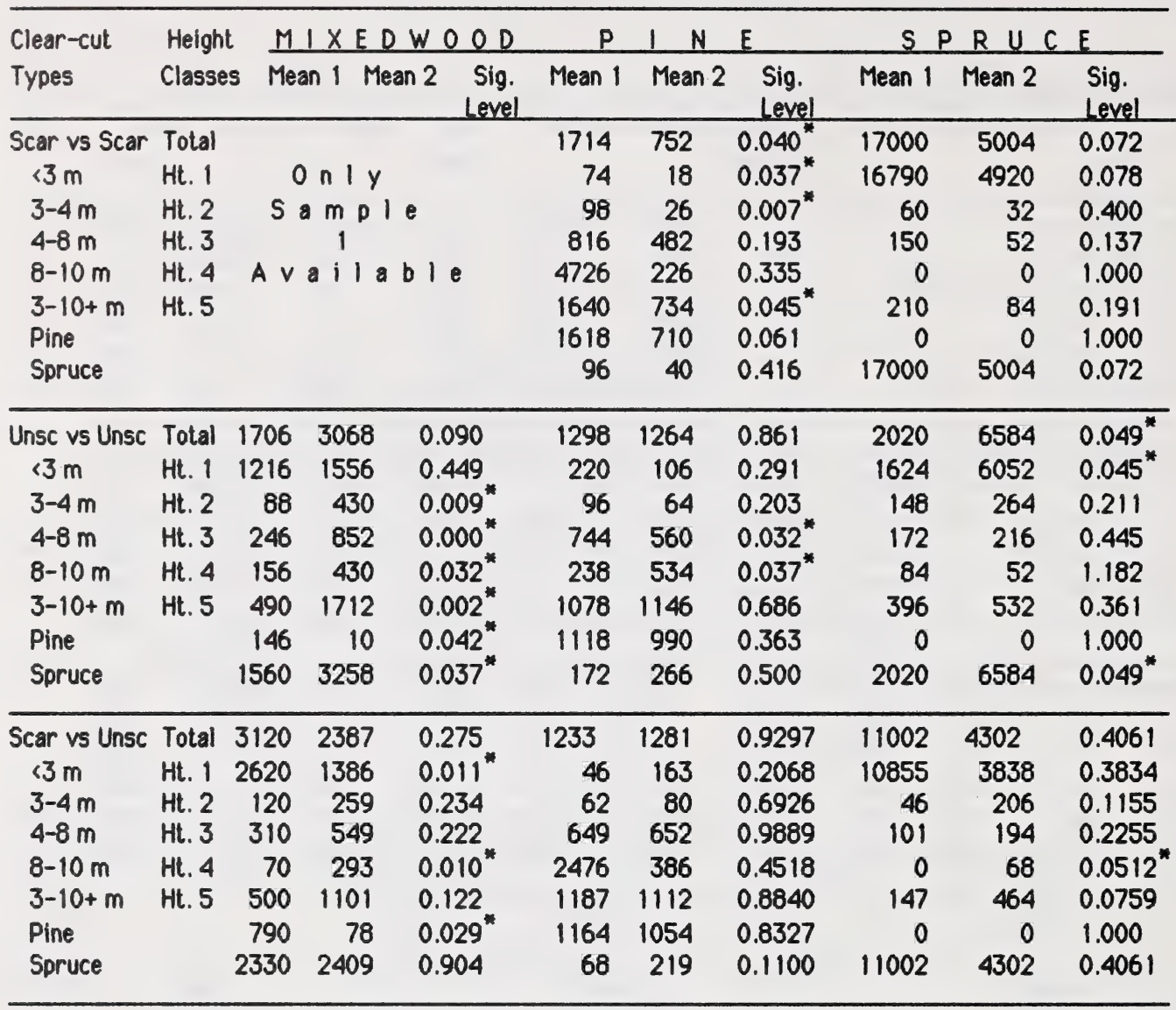

Table 7b. ANOVA of conifer density among the forests.

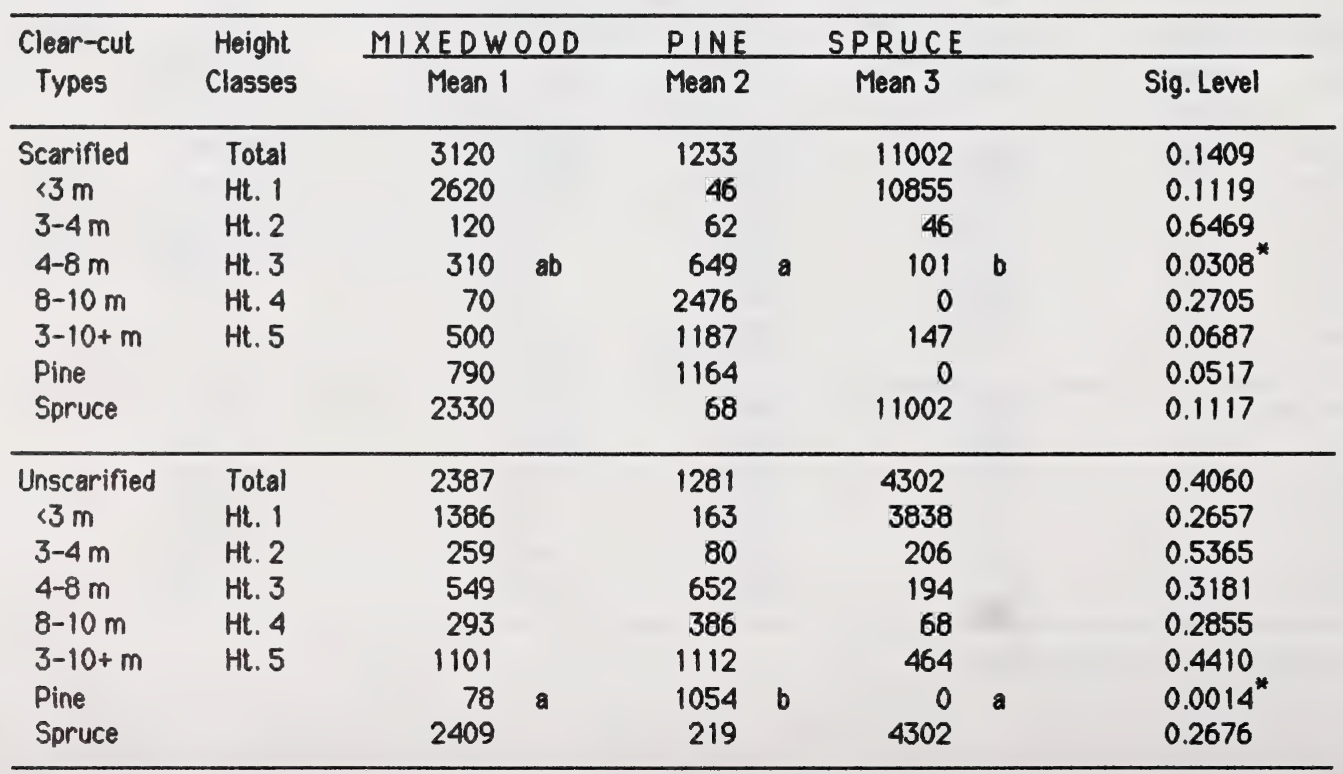


Table 8a. ANOVA of deciduous density within each forest.

\begin{tabular}{llllllllll}
\hline $\begin{array}{l}\text { Clear-cut } \\
\text { Types }\end{array}$ & $\begin{array}{c}\text { Height } \\
\text { Classes }\end{array}$ & MIXEDWOON 1 Mean 2 & $\begin{array}{c}\text { Sig."* } \\
\text { Level }\end{array}$ & $P$ & Mean 1 Mean 2 & $\begin{array}{l}\text { Sig. } \\
\text { Level }\end{array}$ & Mean 1 & Mean 2 & $\begin{array}{l}\text { Sig. } \\
\text { Level }\end{array}$ \\
\hline
\end{tabular}

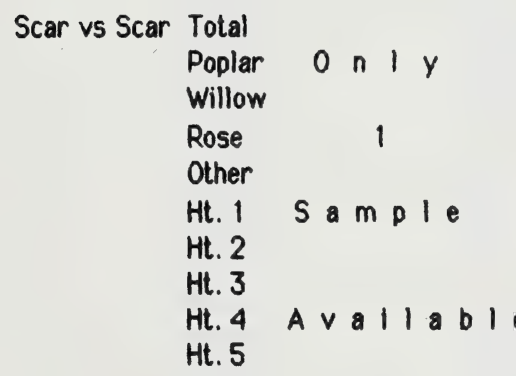

$\begin{array}{rrrrrl}43200 & 42000 & 0.814 & 79200 & 29500 & 0.035^{*} \\ 2500 & 3300 & 0.574 & 5600 & 2600 & 0.113 \\ 2400 & 300 & 0.089 & 6900 & 2500 & 0.125 \\ 26400 & 21500 & 0.297 & 32900 & 15500 & 0.003^{*} \\ 11900 & 16900 & 0.113 & 33800 & 8900 & 0.134 \\ 38800 & 39000 & 0.960 & 77300 & 28800 & 0.036^{*} \\ 1100 & 800 & 0.613 & 1100 & 200 & 0.105 \\ 1900 & 1800 & 0.920 & 800 & 500 & 0.402 \\ 1400 & 400 & 0.090 & 0 & 0 & 1.000 \\ 4400 & 3000 & 0.384 & 1900 & 700 & 0.600\end{array}$

\begin{tabular}{lrrllrlllll}
\hline Unsc vs Unsc Total & 36700 & 64300 & $0.004^{*}$ & 39000 & 38200 & 0.909 & 62600 & 60400 & 0.710 \\
Poplar & 2400 & 1800 & $0.384^{*}$ & 1600 & 1300 & 0.683 & 4600 & 2700 & 0.177 \\
Willow & 200 & 600 & 0.111 & 500 & 700 & 0.720 & 1400 & 8600 & 0.113 \\
Rose & 30500 & 51000 & $0.017^{*}$ & 2100 & 24600 & 0.437 & 48100 & 33400 & $0.045^{*}$ \\
Other & 3600 & 10900 & 0.0 & 15900 & 11600 & 0.280 & 8500 & 15700 & 0.113 \\
Ht. & 36000 & 60500 & $0.004^{*}$ & 36500 & 36400 & 0.989 & 60700 & 59600 & 0.846 \\
Ht. 2 & 300 & 1100 & 0.111 & 700 & 600 & 0.760 & 1000 & 400 & 0.108 \\
Ht. & 400 & 1800 & 0.115 & 1400 & 800 & 0.323 & 800 & 400 & 0.291 \\
Ht. 4 & 0 & 900 & $0.055^{*}$ & 400 & 400 & 1.00 & 100 & 0 & 0.347 \\
Ht.5 & 700 & 3800 & $0.002^{*}$ & 2500 & 1800 & 0.248 & 1900 & 800 & 0.090 \\
\hline Scar vs unsc & Total & 46900 & 50500 & 0.728 & 42600 & 38600 & 0.031 & 54350 & 61500 & 0.801 \\
Poplar & 4300 & 2100 & 0.131 & 2900 & 1450 & 0.077 & 4100 & 3650 & 0.824 \\
Willow & 600 & 400 & 0.380 & 1350 & 600 & 0.551 & 4700 & 5000 & 0.950 \\
Rose & 38400 & 40750 & 0.795 & 23950 & 22800 & 0.742 & 24200 & 40750 & 0.283 \\
Other & 3600 & 7250 & 0.086 & 14400 & 13750 & 0.862 & 21350 & 12100 & 0.549 \\
H.1 & 45300 & 48250 & 0.761 & 38900 & 36450 & $0.002^{*}$ & 53050 & 60150 & 0.797 \\
H.2 & 300 & 700 & 0.317 & 950 & 650 & 0.198 & 650 & 700 & 0.935 \\
H. 3 & 1100 & 1100 & 1.00 & 1850 & 1100 & 0.132 & 650 & 600 & 0.860 \\
H. 4 & 200 & 450 & 0.514 & 900 & 400 & 0.423 & 0 & 50 & 0.423 \\
H.5 & 1600 & 2250 & 0.510 & 3700 & 2150 & 0.186 & 1300 & 1350 & 0.957 \\
\hline
\end{tabular}


Table 8b. ANOVA of deciduous density among forests.

\begin{tabular}{|c|c|c|c|c|c|}
\hline \multirow{2}{*}{$\begin{array}{l}\text { Clear-cut } \\
\text { Types }\end{array}$} & \multirow{2}{*}{$\begin{array}{l}\text { Height } \\
\text { Classes }\end{array}$} & \multirow{2}{*}{$\frac{M I X E D W O O D}{\text { Mean } 1}$} & \multirow{2}{*}{$\frac{P \mid N E}{\text { Mean } 2}$} & \multirow{2}{*}{$\frac{\text { SPRUCE }}{\text { Mean } 3}$} & \\
\hline & & & & & Sig. Level \\
\hline Scarified & $\begin{array}{l}\text { Total } \\
\text { Poplar } \\
\text { Willow } \\
\text { Rose } \\
\text { Other } \\
\text { Ht. } 1 \\
\text { Ht. } 2 \\
\text { Ht. } 3 \\
\text { Ht. } 4 \\
\text { Ht. } 5\end{array}$ & $\begin{array}{r}46900 \\
4300 \\
600 \\
38400 \\
3600 \\
45300 \\
300 \\
1100 \\
200 \\
1600\end{array}$ & $\begin{array}{c}42600 \\
2900 \\
1350 \\
23950 \\
14400 \\
38900 \\
950 \\
1850 \text { b } \\
900 \\
3700 \text { b }\end{array}$ & $\begin{array}{c}54350 \\
4100 \\
4700 \\
24200 \\
21350 \\
53050 \\
650 \\
650 \\
0 \\
1300\end{array}$ & $\begin{array}{l}0.603 \\
0.414 \\
0.191 \\
0.975 \\
0.551 \\
0.526 \\
0.495 \\
0.003^{\star} \\
0.115 \\
0.050^{*}\end{array}$ \\
\hline Unscarified & $\begin{array}{l}\text { Total } \\
\text { Poplar } \\
\text { Willow } \\
\text { Rose } \\
\text { Other } \\
\text { Ht. } 1 \\
\text { Ht. } 2 \\
\text { Ht. } 3 \\
\text { Ht. } 4 \\
\text { Ht. } 5\end{array}$ & $\begin{array}{r}50500 \\
2100 \\
400 \\
40750 \\
7250 \\
48250 \\
700 \\
1100 \\
450 \\
2250\end{array}$ & $\begin{array}{r}38600 \\
1450 \\
600 \\
22800 \\
13750 \\
36450 \\
650 \\
1100 \\
400 \\
2150\end{array}$ & $\begin{array}{r}61500 \\
3650 \\
5000 \\
40750 \\
12100 \\
60150 \\
700 \\
600 \\
50 \\
1350\end{array}$ & $\begin{array}{l}0.274 \\
0.152 \\
0.343 \\
0.282 \\
0.436 \\
0.206 \\
0.990 \\
0.700 \\
0.565 \\
0.788\end{array}$ \\
\hline
\end{tabular}


Table 9a ANOVA of pellet densities within each forest.

\begin{tabular}{|c|c|c|c|c|c|c|c|c|c|c|}
\hline \multirow{2}{*}{$\begin{array}{l}\text { Clear-cut } \\
\text { Types }\end{array}$} & \multirow[t]{2}{*}{ Species } & \multicolumn{3}{|c|}{ MIXEDWOOD } & \multirow{2}{*}{$\frac{P}{\text { Mean } 1}$} & \multirow{2}{*}{$\frac{N}{\text { Mean } 2}$} & \multirow{2}{*}{ 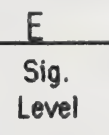 } & \multicolumn{3}{|c|}{$S P R \cup C E$} \\
\hline & & Mean & 1 Mean & $\begin{array}{l}2 \text { Sig. } \\
\text { Level }\end{array}$ & & & & Mean 1 & Mean 2 & $\begin{array}{l}2 \text { Sig. } \\
\text { Level }\end{array}$ \\
\hline Scar vs Scar & $\begin{array}{l}\text { Deer S } \\
\text { Deer W } \\
\text { Deer T } \\
\text { Elk S } \\
\text { Elk W } \\
\text { Elk T } \\
\text { Moose S } \\
\text { Moose W } \\
\text { Moose T } \\
\text { Hare T } \\
\text { Grouse T } \\
\text { Coyote T }\end{array}$ & $\begin{array}{l}0 \\
S \text { A V }\end{array}$ & $\begin{array}{c}n \mid y \\
1\end{array}$ & b I e & $\begin{array}{r}50 \\
70 \\
120 \\
0 \\
10 \\
10 \\
0 \\
40 \\
40 \\
5220 \\
1320 \\
0\end{array}$ & $\begin{array}{r}24 \\
20 \\
44 \\
0 \\
4 \\
4 \\
0 \\
20 \\
20 \\
1100 \\
16 \\
0\end{array}$ & $\begin{array}{l}0.322 \\
0.060 \\
0.004^{*} \\
1.00 \\
0.593 \\
0.590 \\
1.00 \\
0.434 \\
0.434 \\
0.001^{*} \\
0.129 \\
1.00\end{array}$ & $\begin{array}{r}60 \\
108 \\
168 \\
24 \\
20 \\
44 \\
0 \\
0 \\
0 \\
16 \\
36 \\
0\end{array}$ & $\begin{array}{r}48 \\
104 \\
152 \\
24 \\
32 \\
56 \\
0 \\
0 \\
0 \\
0 \\
8 \\
0\end{array}$ & $\begin{array}{l}0.694 \\
0.932 \\
0.816 \\
1.00 \\
0.576 \\
0.561 \\
1.00 \\
1.00 \\
1.00 \\
0.347 \\
0.429 \\
1.00\end{array}$ \\
\hline Unsc vs Unse & $\begin{array}{l}\text { Deer S } \\
\text { Deer W } \\
\text { Deer T } \\
\text { Elk S } \\
\text { Elk W } \\
\text { Elk T } \\
\text { Moose S } \\
\text { Moose W } \\
\text { Moose T } \\
\text { Hare T } \\
\text { Grouse T } \\
\text { Coyote T }\end{array}$ & $\begin{array}{r}20 \\
180 \\
200 \\
0 \\
20 \\
20 \\
0 \\
0 \\
0 \\
0 \\
370 \\
0\end{array}$ & $\begin{array}{r}4 \\
4 \\
8 \\
0 \\
0 \\
0 \\
0 \\
0 \\
0 \\
4696 \\
32 \\
0\end{array}$ & $\begin{array}{l}0.474 \\
0.163 \\
0.124 \\
1.00 \\
0.141 \\
0.141 \\
1.00 \\
1.00 \\
1.00 \\
0.002^{\star} \\
0.167 \\
1.00\end{array}$ & $\begin{array}{r}60 \\
80 \\
140 \\
0 \\
0 \\
0 \\
0 \\
44 \\
44 \\
196 \\
52 \\
0\end{array}$ & $\begin{array}{r}40 \\
310 \\
350 \\
0 \\
0 \\
0 \\
0 \\
40 \\
40 \\
1570 \\
330 \\
0\end{array}$ & $\begin{array}{l}0.539 \\
0.130 \\
0.184 \\
1.00 \\
1.00 \\
1.00 \\
1.00 \\
0.902 \\
0.902 \\
0.130 \\
0.217 \\
1.00\end{array}$ & $\begin{array}{r}0 \\
216 \\
216 \\
0 \\
16 \\
16 \\
0 \\
0 \\
0 \\
116 \\
0 \\
0\end{array}$ & $\begin{array}{r}44 \\
228 \\
272 \\
20 \\
20 \\
40 \\
0 \\
0 \\
0 \\
4 \\
0 \\
0\end{array}$ & $\begin{array}{l}0.0 * \\
0.872 \\
0.482 \\
0.013^{*} \\
0.694 \\
0.074 \\
1.00 \\
1.00 \\
1.00 \\
0.090 \\
1.00 \\
1.00\end{array}$ \\
\hline Scar vs Unsc & $\begin{array}{l}\text { Deer S } \\
\text { Deer W } \\
\text { Deer T } \\
\text { Elk S } \\
\text { Elk W } \\
\text { Elk T } \\
\text { Moose S } \\
\text { Moose W } \\
\text { Moose T } \\
\text { Hare T } \\
\text { Grouse T } \\
\text { Coyote T }\end{array}$ & $\begin{array}{r}20 \\
0 \\
20 \\
0 \\
0 \\
0 \\
0 \\
0 \\
0 \\
0 \\
50 \\
0\end{array}$ & $\begin{array}{r}12 \\
92 \\
104 \\
0 \\
10 \\
10 \\
0 \\
0 \\
0 \\
2348 \\
201 \\
0\end{array}$ & $\begin{array}{l}0.638 \\
0.282 \\
0.178 \\
1.00 \\
0.317 \\
0.317 \\
1.00 \\
1.00 \\
1.00 \\
0.101 \\
0.207 \\
1.00\end{array}$ & $\begin{array}{r}37 \\
45 \\
82 \\
0 \\
7 \\
7 \\
0 \\
30 \\
30 \\
3160 \\
668 \\
0\end{array}$ & $\begin{array}{r}50 \\
195 \\
245 \\
0 \\
0 \\
0 \\
0 \\
42 \\
42 \\
883 \\
191 \\
0\end{array}$ & $\begin{array}{l}0.511 \\
0.330 \\
0.282 \\
1.00 \\
0.145 \\
0.145 \\
1.00 \\
0.360 \\
0.360 \\
0.404 \\
0.548 \\
1.00\end{array}$ & $\begin{array}{r}54 \\
106 \\
160 \\
24 \\
26 \\
50 \\
0 \\
0 \\
0 \\
8 \\
22 \\
0\end{array}$ & $\begin{array}{r}22 \\
222 \\
244 \\
10 \\
18 \\
28 \\
0 \\
0 \\
0 \\
50 \\
0 \\
0\end{array}$ & $\begin{array}{l}0.296 \\
0.003^{*} \\
0.102 \\
0.296 \\
0.333 \\
0.243 \\
1.00 \\
1.00 \\
1.00 \\
0.455 \\
0.257 \\
1.00\end{array}$ \\
\hline
\end{tabular}

$S=$ Summer,$W=$ winter, $T=$ total of year-round 
Table 9b. ANOVA of pellet densities among the forests.

\begin{tabular}{|c|c|c|c|c|c|c|c|c|}
\hline Forest & Species & Mean & & Mean & 2 & Mean 3 & & Sig. Level \\
\hline Scarified & $\begin{array}{l}\text { Deer S } \\
\text { Deer W } \\
\text { Deer T } \\
\text { Elk S } \\
\text { Elk W } \\
\text { Elk T } \\
\text { Moose S } \\
\text { Moose W } \\
\text { Moose T } \\
\text { Hare T } \\
\text { Grouse T } \\
\text { Coyote T }\end{array}$ & $\begin{array}{r}20 \\
0 \\
20 \\
0 \\
0 \\
0 \\
0 \\
0 \\
0 \\
0 \\
50 \\
0\end{array}$ & $\begin{array}{l}b \\
b\end{array}$ & $\begin{array}{r}37 \\
45 \\
82 \\
0 \\
7 \\
7 \\
0 \\
30 \\
30 \\
3160 \\
668 \\
0\end{array}$ & $\begin{array}{l}a \\
a \\
b \\
b\end{array}$ & $\begin{array}{r}54 \\
106 \\
160 \\
24 \\
26 \\
50 \\
0 \\
0 \\
0 \\
8 \\
22 \\
0\end{array}$ & $\begin{array}{l}\text { a } \\
\text { a }\end{array}$ & $\begin{array}{l}0.242 \\
0.059^{*} \\
0.091 \\
1.00 \\
0.040^{*} \\
0.004^{*} \\
1.00 \\
0.035^{*} \\
0.025^{*} \\
0.158 \\
0.312 \\
1.00\end{array}$ \\
\hline Unscarified & $\begin{array}{l}\text { Deer S } \\
\text { Deer W } \\
\text { Deer T } \\
\text { Elk S } \\
\text { Elk W } \\
\text { Elk T } \\
\text { Moose S } \\
\text { Moose W } \\
\text { Moose T } \\
\text { Hare T } \\
\text { Grouse T } \\
\text { Coyote T }\end{array}$ & $\begin{array}{r}12 \\
92 \\
104 \\
0 \\
10 \\
10 \\
0 \\
0 \\
0 \\
2348 \\
201 \\
0\end{array}$ & $\begin{array}{l}\text { a } \\
\text { a }\end{array}$ & $\begin{array}{r}50 \\
195 \\
245 \\
0 \\
0 \\
0 \\
0 \\
42 \\
42 \\
883 \\
191 \\
0\end{array}$ & $\begin{array}{l}b \\
b\end{array}$ & $\begin{array}{r}22 \\
222 \\
244 \\
10 \\
18 \\
28 \\
0 \\
0 \\
0 \\
60 \\
0 \\
0\end{array}$ & $\begin{array}{l}\text { a } \\
\text { a }\end{array}$ & $\begin{array}{l}0.307 \\
0.574 \\
0.482 \\
0.465 \\
0.244 \\
0.232 \\
1.00 \\
0.000 \\
0.000 \\
0.574 \\
0.525 \\
1.00\end{array}$ \\
\hline
\end{tabular}


Table 10a. ANOVA of forb/grass coverage in 32 year-old clear-cuts within each forest.

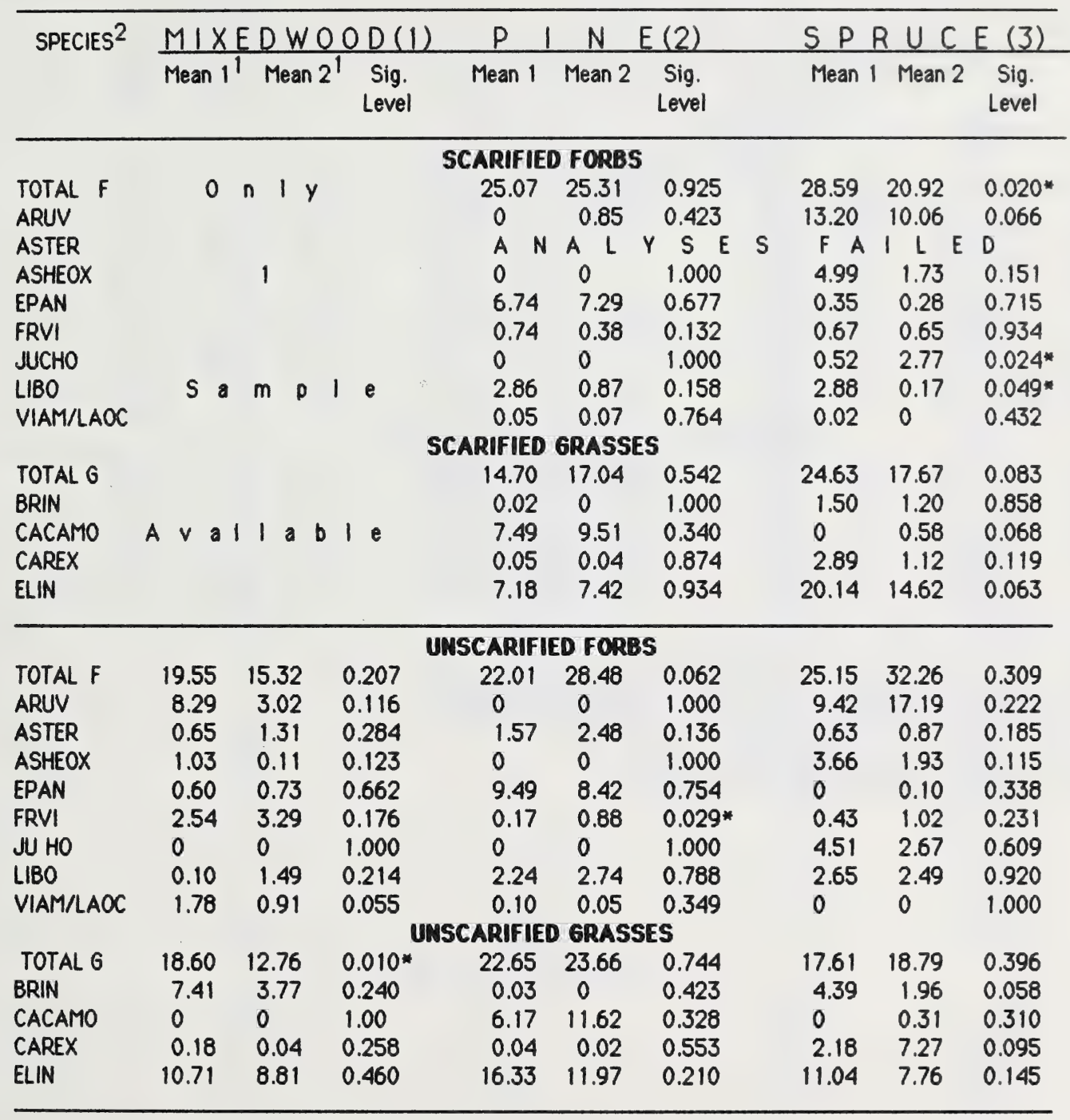


Table 10a continued.

\begin{tabular}{|c|c|c|c|c|c|c|c|c|c|}
\hline \multirow[t]{2}{*}{ SPECIES ${ }^{2}$} & \multicolumn{3}{|c|}{$M \perp \times E D W O O D(1)$} & \multirow{2}{*}{$\frac{P}{\text { Mean } 1}$} & \multirow{2}{*}{$\frac{1 N}{M e a n 2}$} & \multirow{2}{*}{ 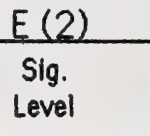 } & \multicolumn{3}{|c|}{$S P R \cup C E(3)$} \\
\hline & Mean $1^{1}$ & Mean $2^{1}$ & $\begin{array}{l}\text { Sig. } \\
\text { Level }\end{array}$ & & & & Mean 1 & Mean 2 & $\begin{array}{l}\text { Sig. } \\
\text { Level }\end{array}$ \\
\hline \multicolumn{10}{|c|}{ SCARIFIED vS UNSCARIFIED FORBS } \\
\hline TOTAL $F$ & 20.02 & 17.44 & 0.335 & 25.190 & 25.25 & 0.988 & 24.76 & 28.71 & 0.529 \\
\hline ARUV & 7.01 & 5.66 & 0.637 & 0.425 & 0 & 0.423 & 11.63 & 13.31 & 0.728 \\
\hline ASTER & 0.65 & 0.98 & 0.502 & 2.055 & 2.02 & 0.958 & 1.28 & 0.75 & 0.341 \\
\hline ASHEOX & 1.12 & 0.57 & 0.310 & 0 & 0 & 1.000 & 3.36 & 2.79 & 0.788 \\
\hline EPAN & 0.32 & 0.67 & 0.196 & 7.015 & 8.96 & 0.084 & 0.31 & 0.05 & $0.049 *$ \\
\hline FRVI & 2.01 & 2.92 & 0.099 & 0.560 & 0.52 & 0.938 & 0.66 & 0.72 & 0.846 \\
\hline JUCOHO & 0 & 0 & 1.000 & 0 & 0 & 1.000 & 1.64 & 3.59 & 0.313 \\
\hline LIBO & 0.05 & 0.80 & 0.241 & 1.865 & 2.49 & 0.604 & 1.52 & 2.57 & 0.522 \\
\hline VIAM/LAOC & 1.95 & 1.35 & 0.242 & 0.060 & 0.07 & 0.634 & 0.01 & 0 & 0.423 \\
\hline \multicolumn{10}{|c|}{ SCARIFIED VS UNSCARIFIED GRASSES } \\
\hline TOTAL $G$ & 18.26 & 15.68 & 0.459 & 15.87 & 23.16 & $0.029 *$ & 21.15 & 18.20 & 0.491 \\
\hline BRIN & 4.55 & 5.59 & 0.646 & 0.01 & 0.01 & 0.808 & 1.35 & 3.17 & 0.274 \\
\hline CACAMO & 0 & 0 & 1.000 & 8.50 & 8.89 & 0.904 & 0.29 & 0.15 & 0.721 \\
\hline CAREX & 0.86 & 0.11 & $0.006^{*}$ & 0.04 & 0.03 & 0.312 & 2.00 & 4.72 & 0.419 \\
\hline ELIN & 12.31 & 9.76 & 0.343 & 7.30 & 14.15 & 0.088 & 17.38 & 9.40 & 0.130 \\
\hline $\begin{array}{l}\text { Mean } 1=5 \\
\text { Total } F=t \\
\text { ASHEOX }= \\
\text { VIAMLAOC } \\
\text { CACAMO = } \\
\text { JUCOHO }=\end{array}$ & $\begin{array}{l}\text { rified } \\
\text { al forbs } \\
\text { stragalus, } \\
\text { Vicea and }\end{array}$ & $\begin{array}{l}\text { Mean } 2= \\
\text { Total } G \\
\text { Hedysaru } \\
\text { d Lathyrus } \\
\text { stis canad } \\
\text { communis a }\end{array}$ & $\begin{array}{l}\text { Unscarifie } \\
G=\text { total gI } \\
\text { um and } 0 x y \\
5 \text { nitrogen- }\end{array}$ & $\begin{array}{l}\text { pis nitroc } \\
\text { ng specie } \\
\text { nontanens } \\
\text { talis }\end{array}$ & $\begin{array}{l}\text { gen-fixing } \\
\text { sis }\end{array}$ & 9 species & & & \\
\hline
\end{tabular}


Table 10b. ANOVA of forb/grass coverage in 32 year-old clear-cuts among forests.

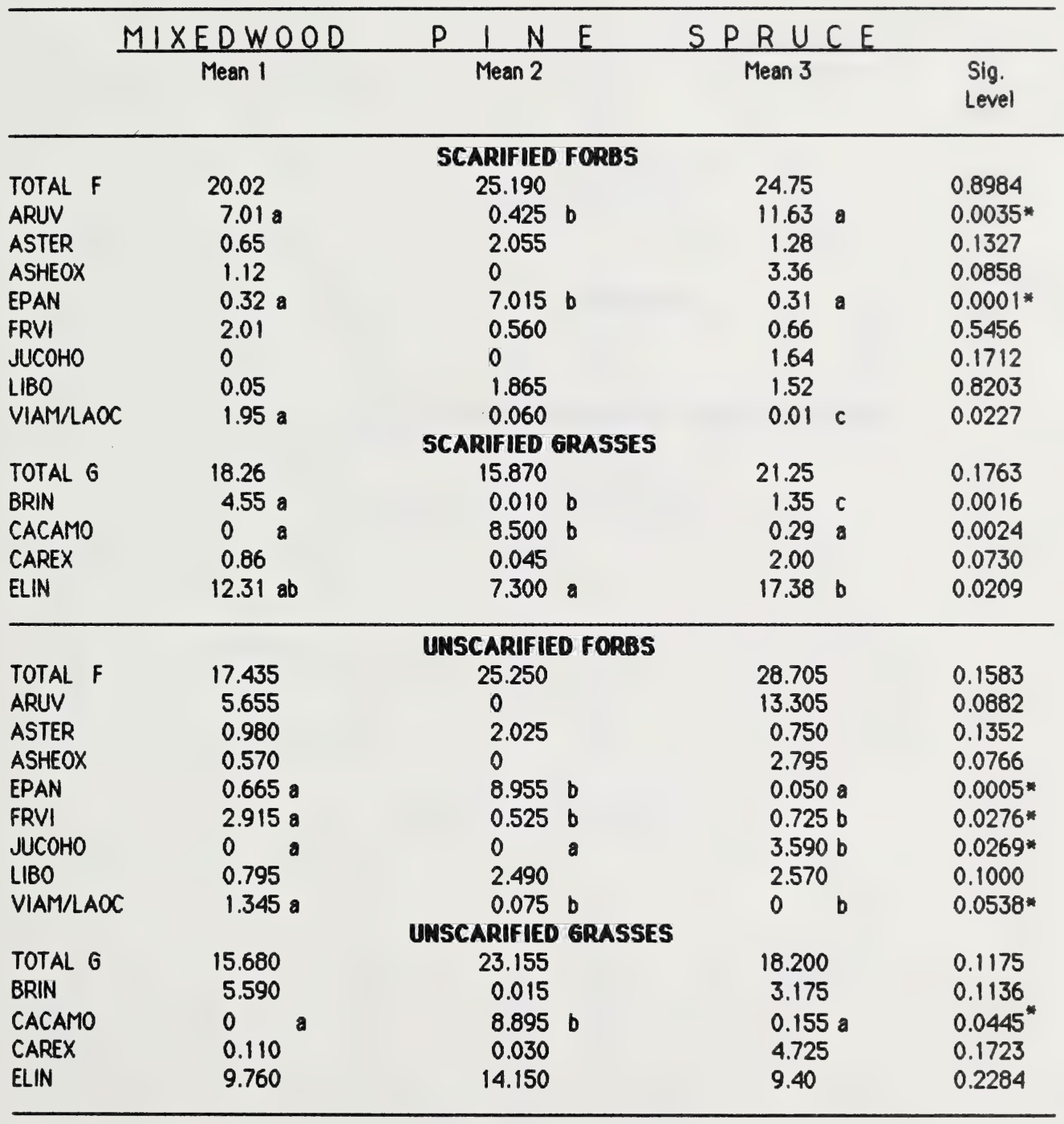


100

Appendix 4

Foliage Cover of Grasses and Forbs 
Table 1. Percent cover of grasses and forbs in mature forests plus scarified (SC) and unscarified (UN) clear-cuts.

\begin{tabular}{|c|c|c|c|c|c|c|c|c|c|}
\hline \multirow{3}{*}{$\begin{array}{c}\text { Forest } \\
\text { Type \& Age }\end{array}$} & & $r$ & $c e$ & $n$ & C & 0 & v & e & $r^{*}$ \\
\hline & \multicolumn{2}{|c|}{ Grasses } & & \multicolumn{2}{|c|}{ Forbs } & & & \multicolumn{2}{|c|}{ Combined } \\
\hline & SC & UN & & SC & UN & & & SC & UN \\
\hline \multicolumn{10}{|c|}{ WHITE SPRUCE FOREST } \\
\hline Mature & \multicolumn{2}{|c|}{28} & \multicolumn{3}{|c|}{16} & & & \multicolumn{2}{|c|}{44} \\
\hline 1 & 8 & 24 & & 1 & 4 & & & 9 & 28 \\
\hline 5 & 54 & 60 & & 42 & 37 & & & 97 & 97 \\
\hline 26 & 23 & 22 & & 18 & 27 & & & 41 & 49 \\
\hline 32 & 21 & 19 & & 25 & 29 & & & 46 & 47 \\
\hline
\end{tabular}

Mature 6

\section{LODGEPOLE PINE FOREST}

$\begin{array}{rrrrrrr}1 & 9 & 13 & - & - & - & - \\ 5 & 64 & 74 & 46 & 38 & 110 & 112 \\ 26 & 20 & 28 & 17 & 12 & 37 & 40 \\ 32 & 16 & 23 & 25 & 25 & 41 & 48\end{array}$

\section{MIXEDWOOD FOREST}

Mature

$\begin{array}{rrrrrrr}1 & 7 & 8 & - & - & - & - \\ 5 & 45 & 56 & 29 & 19 & 74 & 75 \\ 26 & 27 & 17 & 15 & 14 & 42 & 31 \\ 32 & 18 & 16 & 20 & 17 & 38 & 33\end{array}$

Mature

\section{(THREE FORESTS AVES.)}

17

16

44

$\begin{array}{rrrrrrr}1 & 8 & 15 & - & - & - & - \\ 5 & 54 & 63 & 43 & 31 & 94 & 95 \\ 26 & 23 & 22 & 17 & 18 & 40 & 40 \\ 32 & 18 & 19 & 23 & 24 & 42 & 43\end{array}$

* Sample size $(n)=10$ with each replication representing one value. 
Table 2a. Grass cover (foliage) in mature and clear-cut blocks.

\begin{tabular}{|c|c|c|c|c|c|c|c|c|c|}
\hline \multirow[b]{2}{*}{ SPECIES } & \multirow[b]{2}{*}{ Mature } & \multicolumn{2}{|c|}{ Year 1} & \multicolumn{2}{|c|}{ Year 6} & \multicolumn{2}{|c|}{ Year 26} & \multicolumn{2}{|c|}{ Year 32} \\
\hline & & Scar & Unsc & Scar & Unsc & Scar & Unsc & Scar & Unsc \\
\hline \multicolumn{10}{|c|}{ WHITE SPRUCE FOREST } \\
\hline All Species & 28.2 & 8.2 & 23.5 & 53.8 & 60.2 & 22.2 & 21.0 & 21.1 & 18.2 \\
\hline Hairy Wild Rye & 6.4 & 7.0 & 21.0 & 15.7 & 49.1 & 20.7 & 15.4 & 17.4 & 9.4 \\
\hline Sedges & 21.6 & $\operatorname{tr}$ & $\operatorname{tr}$ & 12.1 & 2.6 & 1.2 & 1.3 & 2.0 & 4.7 \\
\hline Brome & 0.1 & 1.2 & 2.5 & 7.2 & 6.6 & 0.1 & 0.6 & 1.3 & 3.2 \\
\hline Bluejoint & 0 & 0 & tr & 0.8 & $\operatorname{tr}$ & $\operatorname{tr}$ & 3.3 & $\operatorname{tr}$ & 0.1 \\
\hline \multicolumn{10}{|c|}{ LODGEPOLE PINE FOREST } \\
\hline All Species & 6.0 & 8.5 & 12.5 & 63.8 & 73.8 & 20.1 & 28.5 & 15.9 & 23.2 \\
\hline Hairy wild Rye & 5.5 & 7.5 & 11.5 & 51.4 & 71.0 & 12.8 & 21.0 & 7.3 & 14.1 \\
\hline Sedges & 0 & 0 & 0 & 4.0 & 0.3 & 0.4 & $\operatorname{tr}$ & $\operatorname{tr}$ & $\operatorname{tr}$ \\
\hline Blue joint & 0.5 & 0.5 & 1.0 & 5.4 & 0.4 & 7.3 & 7.4 & 8.5 & 8.9 \\
\hline Brome & 0 & 0 & 0 & 0 & 0.1 & $\operatorname{tr}$ & $\operatorname{tr}$ & $\operatorname{tr}$ & $\operatorname{tr}$ \\
\hline \multicolumn{10}{|c|}{ MIXEDWOOD FOREST } \\
\hline All Species & - & 6.9 & 8.0 & 45.1 & 55.5 & 25.8 & 17.0 & 18.3 & 15.7 \\
\hline Hairy wild Rye & - & 3.3 & 2.8 & 36.3 & 40.1 & 18.2 & 13.7 & 12.3 & 9.8 \\
\hline Sedges & - & 0 & 0 & 1.3 & 0.6 & 0.6 & 0.4 & 0.9 & 0.1 \\
\hline Brome & - & 2.6 & 0 & 6.4 & 14.7 & 5.5 & 2.3 & 4.6 & 5.6 \\
\hline Bluejoint & - & 0 & 5.2 & 0.1 & 0 & 0 & 0 & 0 & 0 \\
\hline
\end{tabular}

Table 2b. Forb cover (foliage) in mature and clear-cut blocks.

\begin{tabular}{|c|c|c|c|c|c|c|c|c|c|}
\hline \multirow[b]{2}{*}{ SPECIES } & \multirow[b]{2}{*}{ Mature } & \multicolumn{2}{|c|}{ Year 1} & \multicolumn{2}{|c|}{ Year 6} & \multicolumn{2}{|c|}{ Year 26} & \multicolumn{2}{|c|}{ Year 32} \\
\hline & & Scar & Unsc & Scar & Unsc & Scar & Unsc & Scar & Unsc \\
\hline \multicolumn{10}{|c|}{ WHITE SPRUCE FOREST } \\
\hline All Species & 15.6 & 1.2 & 4.1 & 42.8 & 37.2 & 17.8 & 26.3 & 25.0 & 29.0 \\
\hline Aster & 0.3 & 0.1 & 0.3 & 8.8 & 5.0 & 0.2 & 0.4 & 1.3 & 0.8 \\
\hline Fireweed & 0 & 0 & 0.1 & 9.1 & 0.9 & 8.0 & 12.0 & 0.3 & 0.1 \\
\hline Strawberry & & & & & & 0.4 & 0.5 & 0.7 & 0.7 \\
\hline Bedstraw & 3.0 & 0.3 & 1.5 & 2.7 & 3.0 & 1.2 & 0.8 & 1.1 & 0.6 \\
\hline Indian Potatoe & 1.0 & 0.4 & 0.7 & 0.7 & 2.4 & 1.3 & 2.0 & 2.2 & 1.5 \\
\hline \multicolumn{10}{|c|}{ LODGEPOLE PINE FOREST } \\
\hline All Species & - & - & - & 46.0 & 38.4 & 15.5 & 11.0 & 25.2 & 25.2 \\
\hline Aster & - & - & - & 7.2 & 8.9 & 1.0 & 0.8 & 2.1 & 2.0 \\
\hline Fireweed & - & - & - & 18.9 & 13.5 & 2.8 & 4.5 & 7.0 & 9.0 \\
\hline Dewberry & - & - & - & 11.3 & 6.8 & $\operatorname{tr}$ & $\operatorname{tr}$ & 1.4 & 1.6 \\
\hline Bedstraw & - & - & - & 0.7 & 0.5 & 0.1 & $\operatorname{tr}$ & 0.1 & tr \\
\hline Mertensia & - & - & - & 1.2 & 1.6 & 1.1 & 0.6 & 1.0 & 1.2 \\
\hline Strawberry & - & - & - & & & 0.4 & 0.3 & 0.6 & 0.5 \\
\hline \multicolumn{10}{|c|}{ MIXEDWOOD FOREST } \\
\hline All Species & - & - & - & 29.1 & 18.9 & 15.8 & 13.6 & 20.0 & 17.4 \\
\hline Aster & - & - & - & 3.9 & 2.5 & 1.0 & 1.1 & 0.6 & 1.2 \\
\hline Fireweed & - & - & - & 1.6 & 2.4 & 0.3 & 0.3 & 0.3 & 0.7 \\
\hline Strawberry & - & - & - & 11.1 & 5.0 & 1.5 & 1.9 & 2.0 & 2.9 \\
\hline Bedstraw & - & - & - & 3.4 & 1.1 & 1.7 & 0.8 & 1.5 & 0.8 \\
\hline Solomon Seal & - & - & - & 2.0 & 1.1 & $\operatorname{tr}$ & $\operatorname{tr}$ & 1.4 & 1.4 \\
\hline
\end{tabular}


Table 3. Foliage cover of grasses and forbs 32 years after logging.

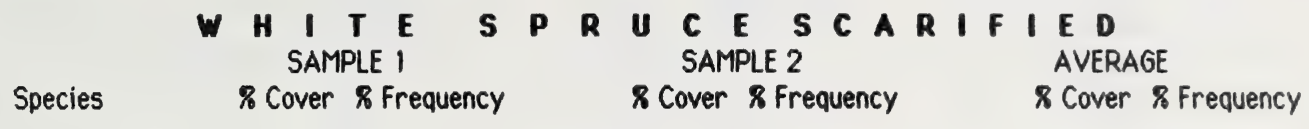

\section{FORBS}

\begin{tabular}{|c|c|c|c|c|c|c|}
\hline$A C M I$ & 0 & 0 & 0.09 & 21 & 0.045 & 10.5 \\
\hline$A G G L$ & 0 & 1 & 0.02 & 2 & 0.01 & 1.5 \\
\hline $\mathrm{ANCH}$ & 0.05 & 7 & 0.16 & 17 & 0.105 & 12 \\
\hline AN MU & 0.01 & 1 & 0.02 & 2 & 0.015 & 1.5 \\
\hline ANPA & 0.08 & 14 & 0.02 & 4 & 0.05 & 9 \\
\hline ANPU & 0.20 & 11 & 0.21 & 13 & 0.205 & 12 \\
\hline$A Q B R$ & 0.05 & 5 & 0.03 & 4 & 0.04 & 4.5 \\
\hline ARUV* & 13.20 & 65 & 10.06 & 43 & 11.63 & 54 \\
\hline AS CO & 0.05 & 2 & 0 & 0 & 0.021 & 1 \\
\hline $\mathrm{ASCl}$ & 1.55 & 77 & 0.71 & 58 & 1.13 & 67 \\
\hline AS SI & 0.09 & 6 & 0.16 & 11 & 0.13 & 8.5 \\
\hline AS AL & 0.01 & 1 & 0 & 0 & 0.005 & 0.5 \\
\hline AS FR & 0.97 & 23 & 0.12 & 4 & 0.545 & 13.5 \\
\hline AS ST & 0.06 & 4 & 0.41 & 12 & 0.235 & 8 \\
\hline$B O B O$ & 0.01 & 2 & 0.01 & 2 & 0.01 & 2 \\
\hline CARO & 0.08 & 17 & 0.12 & 29 & 0.10 & 23 \\
\hline CAMI & 0.08 & 7 & 0.04 & 2 & 0.06 & 4.5 \\
\hline $\mathrm{COCA}$ & 0.01 & 1 & 0 & 0 & 0.005 & 0.5 \\
\hline CY CA & 0.02 & 3 & 0.12 & 1 & 0.07 & 2 \\
\hline CY PA & 0.01 & 1 & 0.01 & 1 & 0.01 & 1 \\
\hline EP AN & 0.35 & 18 & 0.28 & 22 & 0.315 & 20 \\
\hline EQ AR & 0.03 & 8 & 0.03 & 6 & 0.03 & 7 \\
\hline ERCA & 0.01 & 2 & 0.07 & 6 & 0.04 & 4 \\
\hline ER GL & 0 & 1 & 0.03 & 4 & 0.015 & 2.5 \\
\hline FR VI & 0.67 & 40 & 0.65 & 35 & 0.66 & 37.5 \\
\hline GA BO & 0.61 & 58 & 1.51 & 79 & 1.06 & 68.5 \\
\hline GE AM & 0.02 & 4 & 0.18 & 24 & 0.10 & 14 \\
\hline GE CR & 0.09 & 14 & 0 & 0 & 0.045 & 7 \\
\hline GE LI & 0.34 & 18 & 0.18 & 7 & 0.26 & 12.5 \\
\hline HA HY & 0.01 & 2 & 0 & 1 & 0.005 & 1.5 \\
\hline HA VI & 0.02 & 5 & 0 & 0 & 0.01 & 2.5 \\
\hline HE AL & 1.70 & 43 & 0.10 & 8 & 0.90 & 25.5 \\
\hline HE MA & 1.93 & 36 & 0.64 & 35 & 1.285 & 35.5 \\
\hline HI UM & 0.02 & 5 & 0 & 0 & 0.01 & 2.5 \\
\hline JU HO* & 0 & 0 & 2.77 & 18 & 1.385 & 9 \\
\hline JU CO* & 0.52 & 7 & 0 & 0 & 0.26 & 3.5 \\
\hline$\angle A O C$ & 0.02 & 1 & 0 & 0 & 0.01 & 0.5 \\
\hline $\mathrm{LIPH}$ & 0.11 & 14 & 0 & 0 & 0.055 & 7 \\
\hline$\angle I B O$ & 2.88 & 42 & 0.17 & 14 & 1.525 & 28 \\
\hline ME PA & 0.57 & 40 & 0.05 & 4 & 0.31 & 22 \\
\hline OX SP & 0.30 & 15 & 0.22 & 8 & 0.26 & 11.5 \\
\hline OXMO & 0.02 & 3 & 0.24 & 11 & 0.13 & 7 \\
\hline PAFI & 0.01 & 2 & 0 & 1 & 0.005 & 1.5 \\
\hline
\end{tabular}




$\begin{array}{llr}\text { PE NA } & 0 & 1 \\ \text { PE SP } & 0.52 & 22 \\ \text { PY AS } & 0.29 & 19 \\ \text { PY SE (OR SE) } & 0.09 & 11 \\ \text { PY SP } & 0.18 & 24 \\ \text { RU PU } & 0.01 & 1 \\ \text { SE PA } & 0 & 1 \\ \text { SE PS } & 0.06 & 10 \\ \text { SI MO } & 0 & 0 \\ \text { SM ST } & 0 & 0 \\ \text { SM RA } & 0 & 0 \\ \text { SO DE } & 0.05 & 7 \\ \text { TA OF } & 0.09 & 13 \\ \text { TO GL } & 0 & 1 \\ \text { VI AM } & 0 & 1 \\ \text { VISP } & 0.02 & 3 \\ \text { ZI CO } & 0 & 0 \\ \text { ZY EL } & 0.51 & 37 \\ \text { UN FO } & 0.01 & 20\end{array}$

TOTAL

FORB COVER $\quad 28.99 \%$

$\begin{array}{lr}0 & 1 \\ 0.07 & 5 \\ 0.05 & 4 \\ 0.08 & 6 \\ 0.04 & 9 \\ 0 & 0 \\ 0 & 0 \\ 0.15 & 26 \\ 0.04 & 3 \\ 0.35 & 24 \\ 0.03 & 2 \\ 0.13 & 11 \\ 0.20 & 26 \\ 0 & 0 \\ 0 & 0 \\ 0.04 & 7 \\ 0.03 & 1 \\ 0.28 & 22 \\ 0 & 1\end{array}$

$\begin{array}{lc}0 & 0.5 \\ 0.295 & 13.5 \\ 0.17 & 11.5 \\ 0.085 & 8.5 \\ 0.11 & 16.5 \\ 0.005 & .05 \\ 0 & 0.5 \\ 0.105 & 18 \\ 0.02 & 1.5 \\ 0.175 & 12 \\ 0.015 & 1 \\ 0.09 & 9 \\ 0.145 & 19.5 \\ 0 & 0.5 \\ 0 & 0.5 \\ 0.03 & 5 \\ 0 & 0 \\ 0.395 & 29.5 \\ 0.005 & 1.5\end{array}$

$20.92 \%$

$24.74 \%$

\section{GRASSES}

$\begin{array}{llr}\text { AG TR } & .008 & 2 \\ \text { BR IN } & 1.50 & 23 \\ \text { CA AU } & 1.27 & 35 \\ \text { CA CA } & 0 & 0 \\ \text { CA CP } & 0.52 & 13 \\ \text { CA MO } & 0 & 0 \\ \text { CA EB } & 1.10 & 32 \\ \text { EL IN } & 20.14 & 97 \\ \text { PO SP } & 0.01 & 1 \\ \text { UN GR } & 0.01 & 1\end{array}$

TOTAL GRASS

COVER

$24.63 \%$

$\begin{array}{cr}0.15 & 3 \\ 1.20 & 37 \\ 0.30 & 19 \\ 0.01 & 1 \\ 0.55 & 16 \\ 0.57 & 17 \\ 0.27 & 11 \\ 14.62 & 98 \\ 0 & 0 \\ 0 & 0\end{array}$

$0.115 \quad 2.5$

$1.35 \quad 30$

$0.785 \quad 27$

$0.005 \quad 0.5$

$0.535 \quad 14.5$

$0.285 \quad 8.5$

$0.685 \quad 21.5$

$17.38 \quad 97.5$

$\begin{array}{ll}0.005 & 0.5 \\ 0.005 & 0.5\end{array}$

$17.67 \%$

$21.15 \%$

LICHENS, MOSSES, FERNS

HY SP

$1.20 \quad 24$

7.02

64

4.11

44

TOTAL FORB AND

GRASS COVER.

$53.22 \%$

$38.59 \%$

$45.89 \%$

* Shrubs buts used as forbs for cover values. 


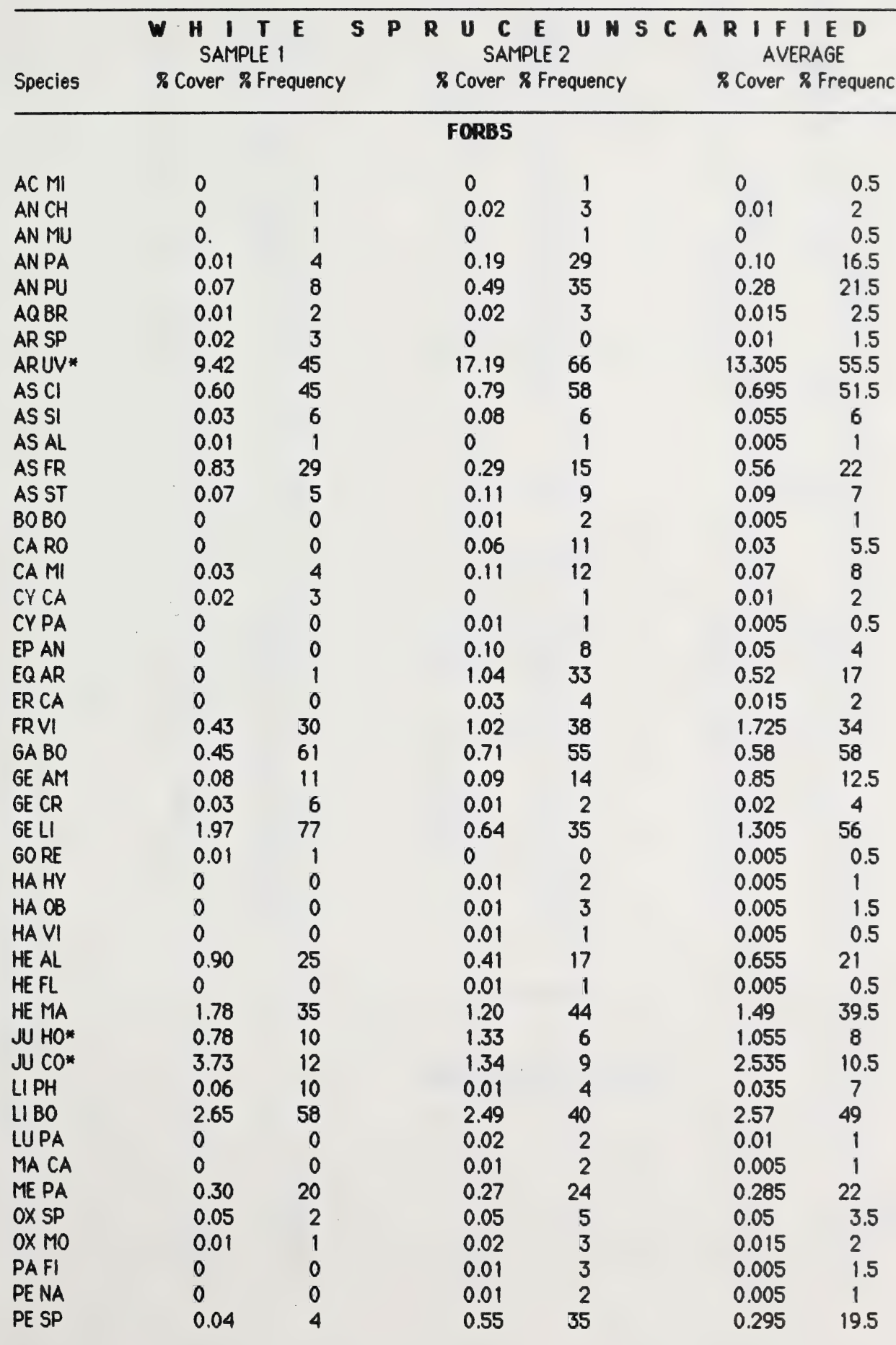




$\begin{array}{lll}\text { PY AS } & 0.19 & 22 \\ \text { PY SE (OR SE) } & 0.10 & 21 \\ \text { PY SP } & 0.15 & 25 \\ \text { RA AC } & 0 & 0 \\ \text { RU PU } & 0.02 & 2 \\ \text { SE PS } & 0.02 & 7 \\ \text { SM ST } & 0.03 & 5 \\ \text { SM RA } & 0 & 0 \\ \text { SO DE } & 0.01 & 1 \\ \text { SO AR } & 0 & 0 \\ \text { SO GI } & 0.01 & 1 \\ \text { TA OF } & 0.01 & 2 \\ \text { TO GL } & 0 & 0 \\ \text { TR PR } & 0 & 0 \\ \text { VI SP } & 0 & 0 \\ \text { ZI CO } & 0 & 0 \\ \text { ZY EL } & 0.22 & 21 \\ \text { UN FO } & 0 & 0 \\ \text { TO } & & \end{array}$

TOTAL

FORB COVER $\quad 25.15 \%$

$\begin{array}{lr}0.25 & 16 \\ 0.04 & 6 \\ 0.14 & 19 \\ 0.02 & 1 \\ 0.08 & 8 \\ 0.06 & 14 \\ 0.17 & 10 \\ 0.01 & 1 \\ 0.22 & 10 \\ 0.01 & 1 \\ 0.08 & 3 \\ 0.10 & 17 \\ 0.14 & 4 \\ 0.04 & 3 \\ 0.02 & 5 \\ 0.02 & 1 \\ 0.18 & 17 \\ 0 & 1\end{array}$

32.358

$\begin{array}{lc}0.22 & 19 \\ 0.07 & 13.5 \\ 0.145 & 22 \\ 0.01 & 0.5 \\ 0.05 & 4.5 \\ 0.04 & 10.5 \\ 0.10 & 7.5 \\ 0.005 & 0.5 \\ 0.115 & 5.5 \\ 0.005 & 0.5 \\ 0.045 & 2 \\ 0.055 & 9.5 \\ 0.07 & 2 \\ 0.02 & 1.5 \\ 0.01 & 2.5 \\ 0.01 & 0.5 \\ 0.20 & 19 \\ 0 & 0.5\end{array}$

28.758

\section{GRASSES}

$\begin{array}{llr}\text { AG SC } & 0 & 0 \\ \text { BR IN } & 4.39 & 68 \\ \text { CA AU } & 0.57 & 28 \\ \text { CA CA } & 0 & 0 \\ \text { CA CP } & 0.81 & 16 \\ \text { CA MO } & 0 & 0 \\ \text { CA SP } & 0 & 0 \\ \text { CA EB } & 0.80 & 26 \\ \text { EL IN } & 11.04 & 98 \\ \text { JU BA } & 0 & 0 \\ \text { JU SP } & 0 & 0 \\ \text { POPR } & 0 & 0 \\ \text { UN GR } & 0 & 1\end{array}$

TOTAL GRASS

COVER

17.618

$\begin{array}{lr}0.13 & 6 \\ 1.96 & 52 \\ 0.78 & 20 \\ 0.16 & 4 \\ 3.09 & 49 \\ 0.15 & 5 \\ 0 & 0 \\ 1.11 & 38 \\ 7.76 & 78 \\ 1.33 & 15 \\ 0.01 & 1 \\ 0.01 & 2 \\ 0.01 & 1\end{array}$

$\begin{array}{lc}0.065 & 3 \\ 3.175 & 60 \\ 0.675 & 24 \\ 0.08 & 2 \\ 1.95 & 32.5 \\ 0.075 & 2.5 \\ 1.145 & 7 \\ 0.955 & 32 \\ 9.40 & 88 \\ 0.665 & 7.5 \\ 0.005 & 0.5 \\ 0.005 & 1 \\ 0.005 & 1\end{array}$

18.798

18.208

LICHENS, MOSSES, FERHS

HY SP

$5.95 \quad 56$

6.21

49

6.08

52.5

TOTAL FORB AND 


\begin{tabular}{|c|c|c|c|c|c|c|}
\hline \multirow[b]{2}{*}{ Species } & \multicolumn{2}{|c|}{$\begin{array}{l}\text { L O D D } 6 \text { E P O L E } \\
\text { SAMPLE I }\end{array}$} & \multicolumn{4}{|c|}{$\begin{array}{l}\text { P I N E } \\
\text { SAMPLE } 2\end{array}$} \\
\hline & \multicolumn{2}{|c|}{8 Cover 8 Frequency } & \multicolumn{2}{|c|}{$\%$ Cover 8 Frequency } & \multicolumn{2}{|c|}{ \& Cover \& Frequency } \\
\hline \multicolumn{7}{|c|}{ FORBS } \\
\hline$A C M I$ & 0.01 & 2 & 0 & 0 & 0.005 & 1 \\
\hline$A C R U$ & 0 & 0 & 0.50 & 12 & 0.25 & 6 \\
\hline ARNU & 0 & 0 & 0.24 & 6 & 0.12 & 3 \\
\hline ARSP & 0.54 & 43 & 1.00 & 57 & 0.77 & 50 \\
\hline ARUV & 0 & 0 & 0.85 & 1 & 0.425 & 0.5 \\
\hline AS CO & 0.45 & 14 & 1.69 & 45 & 1.07 & 29.5 \\
\hline $\mathrm{ASCl}$ & 1.39 & 65 & 0.58 & 33 & 0.985 & 49 \\
\hline$B O B O$ & 0.01 & 2 & 0 & 0 & 0.005 & 1 \\
\hline CAMI & 0.08 & 6 & 0.10 & 4 & 0.09 & 5 \\
\hline $\mathrm{COCA}$ & 4.27 & 89 & 2.94 & 70 & 3.605 & 79.5 \\
\hline DE GL & 0.04 & 2 & 0.16 & 9 & 0.10 & 5.5 \\
\hline EP AN & 6.74 & 94 & 7.29 & 80 & 7.015 & 87 \\
\hline EQ AR & 0.18 & 31 & 0.48 & 28 & 0.33 & 29.5 \\
\hline FRVI & 0.74 & 44 & 0.38 & 29 & 0.56 & 36.5 \\
\hline GA BO & 0.12 & 19 & 0.04 & 6 & 0.08 & 12.5 \\
\hline GA TR & 0.02 & 3 & 0.06 & 8 & 0.04 & 5.5 \\
\hline GE BI & 0 & 0 & 0.19 & 4 & 0.095 & 2 \\
\hline GE CR & 0 & 1 & 0.06 & 7 & 0.03 & 4 \\
\hline GE RI & 0 & 0 & 0.09 & 2 & 0.045 & 1 \\
\hline HA VI & 0 & 0 & 0 & 1 & 0 & 0.5 \\
\hline HE LN & 0.25 & 5 & 2.43 & 26 & 1.34 & 15.5 \\
\hline HE FL & 0.16 & 32 & 0.12 & 13 & 0.14 & 22.5 \\
\hline$\angle A O C$ & 0.02 & 3 & 0.15 & 17 & 0.085 & 10 \\
\hline LE GR & 0.22 & 1 & 0 & 0 & 0.11 & 1 \\
\hline LI BO & 2.86 & 64 & 0.87 & 30 & 1.865 & 47 \\
\hline MA CA & 0.61 & 39 & 0.60 & 50 & 0.605 & 44.5 \\
\hline ME PA & 1.26 & 49 & 0.80 & 43 & 1.03 & 46 \\
\hline PAFI & 0 & 1 & 0 & 0 & 0 & 0.5 \\
\hline PE SP & 1.48 & 56 & 0.34 & 23 & 0.91 & 39.5 \\
\hline PY AS & 0.31 & 28 & 0.29 & 30 & 0.30 & 29 \\
\hline PY SP & 0.25 & 37 & 0.06 & 11 & 0.155 & 24 \\
\hline RUPU & 1.46 & 70 & 1.24 & 59 & 1.35 & 64.5 \\
\hline SM ST & 0 & 0 & 0.03 & 1 & 0.015 & 0.5 \\
\hline SO SP & 0.01 & 1 & 0 & 0 & 0.005 & 0.5 \\
\hline SPLU & 0.05 & 7 & 0.35 & 24 & 0.20 & 15.5 \\
\hline ST AM & 0.04 & 5 & 0.15 & 6 & 0.095 & 10.5 \\
\hline TA OF & 0.05 & 7 & 0.17 & 7 & 0.11 & 7 \\
\hline THVE & 0.01 & 1 & 0.52 & 10 & 0.265 & 5.5 \\
\hline TR PR & 0 & 0 & 0 & 1 & 0 & 0.5 \\
\hline VACA & 1.20 & 21 & 0.21 & 7 & 0.705 & 14 \\
\hline VAVI & 0.15 & 4 & 0 & 0 & 0.075 & 2 \\
\hline VI AM & 0.03 & 3 & 0.01 & 1 & 0.02 & 2 \\
\hline VISP & 0.06 & 9 & 0.32 & 12 & 0.19 & 10.5 \\
\hline \multicolumn{7}{|l|}{ TOTAL } \\
\hline FORB COVER & 25.078 & & 25.318 & & 25.198 & \\
\hline
\end{tabular}


GRASSES

$\begin{array}{llr}\text { AG TR } & 0 & 0 \\ \text { BR IN } & 0.02 & 2 \\ \text { CA AU } & 0.05 & 3 \\ \text { CA CA } & 7.49 & 91 \\ \text { CA SP } & 0 & 0 \\ \text { EL IN } & 7.18 & 79 \\ \text { FE RU } & 0 & 0 \\ \text { POPA } & 0 & 0 \\ \text { POPR } & 0 & 0\end{array}$

TOTAL GRASS

$14.75 \%$

$\begin{array}{lr}0.03 & 2 \\ 0 & 0 \\ 0 & 0 \\ 9.51 & 90 \\ 0.04 & 2 \\ 7.42 & 57 \\ 0.01 & 1 \\ 0.01 & 1 \\ 0.02 & 1\end{array}$

0.015
0.01

$0.025 \quad 1.5$

$8.5 \quad 90.5$

$0.02 \quad 1$

$7.30 \quad 68$

$0.005 \quad 0.5$

$0.005 \quad 0.5$

$0.01 \quad 0.5$

COVER

17.048

$15.89 \%$

LICHENS, MOSSES, FERNS

$\begin{array}{lcclccr}\text { CL SP } & 0.01 & 1 & 0.02 & 2 & 0.015 & 1.5 \\ \text { GY DR } & 0.01 & 2 & 0.01 & 1 & 0.01 & 1.5 \\ \text { HY SP } & 15.76 & 64 & 7.75 & 45 & 11.755 & 54.5 \\ \text { LY SP } & 0 & 0 & 0.01 & 1 & 0.005 & 0.5 \\ \text { PE AP } & 0.14 & 6 & 0 & 0 & 0.07 & 3\end{array}$

TOTAL FORB AND

GRASS COVER

$39.81 \%$

42.358

$41.08 \%$ 


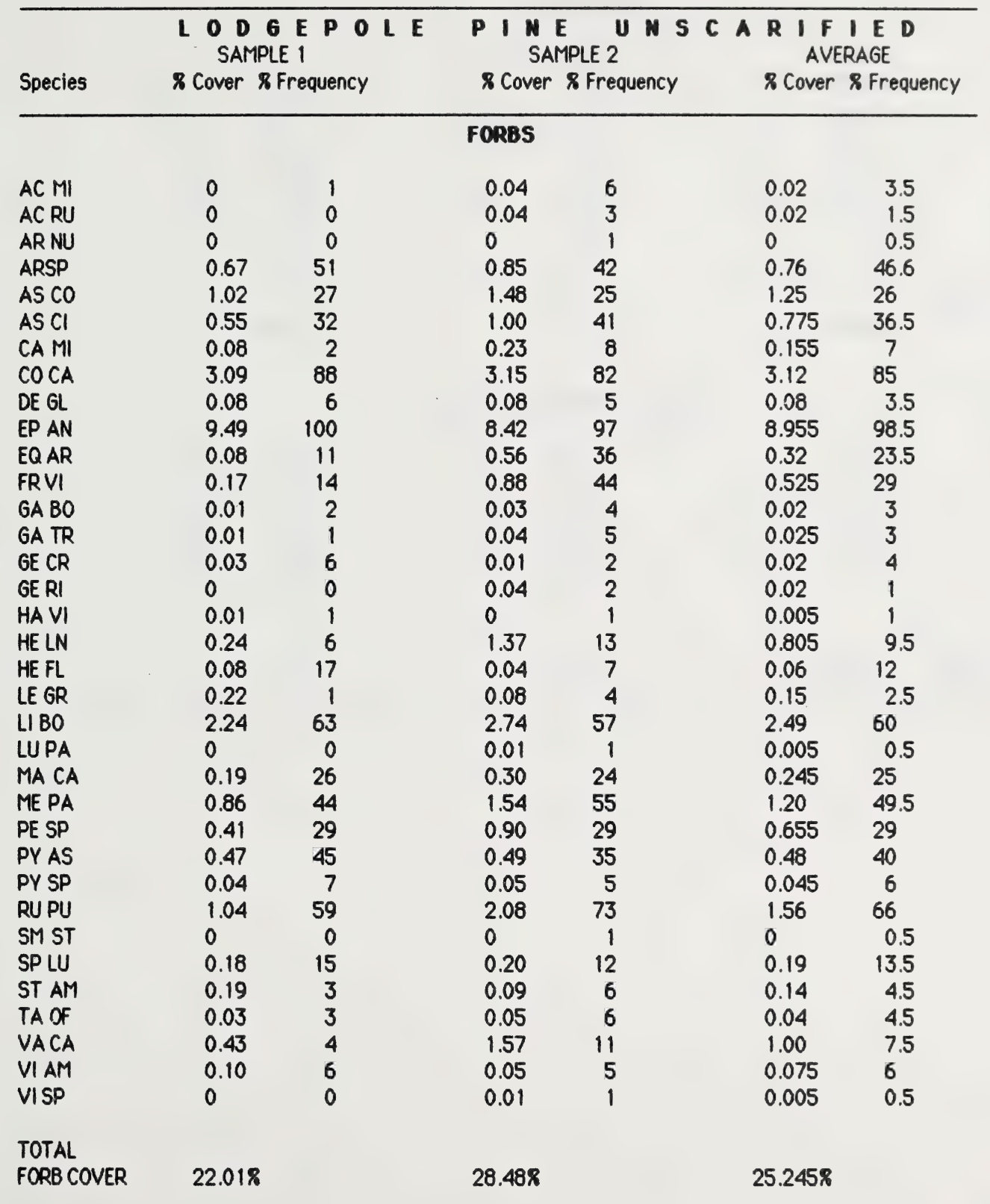


GRASSES

$\begin{array}{lcr}\text { BR IN } & 0.03 & 1 \\ \text { CA AU } & 0.03 & 4 \\ \text { CA CA } & 6.17 & 62 \\ \text { CA SP } & 0.01 & 1 \\ \text { EL IN } & 16.33 & 85 \\ \text { FE SP } & 0.08 & 1 \\ \text { PH PR } & 0 & 0 \\ \text { POPR } & 0 & 0 \\ \text { TOTAL GRASS } & & \\ \text { COVER } & 22.658\end{array}$

$\begin{array}{lrcc}0 & 0 & 0.015 & 0.5 \\ 0.02 & 2 & 0.025 & 3 \\ 11.62 & 85 & 8.895 & 73.5 \\ 0 & 1 & 0.005 & 1 \\ 11.97 & 82 & 14.15 & 83.5 \\ 0 & 0 & 0.08 & 1 \\ 0.01 & 1 & 0.005 & 0.5 \\ 0.04 & 4 & 0.02 & 2 \\ & & & \\ 23.668 & & & 23.1558\end{array}$

LICHENS, MOSSES, FERNS

$\begin{array}{llrrrrr}\text { CL SP } & 0.04 & 5 & 0.09 & 8 & 0.065 & 6.5 \\ \text { GY DR } & 0.01 & 2 & 0 & 0 & 0.005 & 1 \\ \text { HY SP } & 5.06 & 41 & 10.06 & 47 & 7.56 & 44 \\ \text { PE AP } & 0.16 & 7 & 0.08 & 5 & 0.12 & 6 \\ \text { PLSC } & 0 & 0 & 0.07 & 2 & 0.035 & 1\end{array}$




\section{I X E \\ SAMPLE 1 NO SAMPLE 2}

Species 8 Cover 8 Frequency

\section{FORBS}

$\begin{array}{llr}\text { AC MI } & 0.56 & 75 \\ \text { AG GL } & 0.07 & 5 \\ \text { AN MU } & 0.03 & 8 \\ \text { AQ BR } & 0 & 1 \\ \text { ARUV } & 7.01 & 42 \\ \text { ARSP } & 0 & 0 \\ \text { AS CO } & 0.18 & 10 \\ \text { AS CI } & 0.47 & 22 \\ \text { AS AL } & 0.13 & 10 \\ \text { AS FR } & 0.21 & 10 \\ \text { BO BO } & 0 & 1 \\ \text { CA RO } & 0.03 & 3 \\ \text { EP AN } & 0.32 & 17 \\ \text { EQ AR } & 0 & 0 \\ \text { ER CA } & 0.10 & 6 \\ \text { ER GL } & 0.10 & 7 \\ \text { FRVI } & 2.01 & 80 \\ \text { GA BO } & 1.50 & 96 \\ \text { GE CR } & 0.05 & 5 \\ \text { HE MA } & 0.24 & 12 \\ \text { LA OC } & 1.52 & 84 \\ \text { LI PH } & 0.02 & 3 \\ \text { LI BO } & 0.05 & 4 \\ \text { ME PA } & 0.33 & 25 \\ \text { OX SP } & 0.54 & 14 \\ \text { PY AS } & 0 & 1 \\ \text { PY SE (OR SE) } & 0.01 & 1 \\ \text { SE PA } & 0.01 & 1 \\ \text { SE PS } & 0.02 & 5 \\ \text { SI MO } & 0 & 1 \\ \text { SM ST } & 1.40 & 59 \\ \text { ST LO } & 0 & 1 \\ \text { SY AL } & 2.30 & 63 \\ \text { TA OF } & 0.14 & 14 \\ \text { TR PR } & 0.12 & 5 \\ \text { TR RE } & 0.02 & 2 \\ \text { VI AM } & 0.43 & 39 \\ \text { VISP } & 0.09 & 16 \\ \text { UN FO } & 0.01 & 2 \\ & & \end{array}$

TOTAL

FORB COVER $\quad 20.028$ 


\section{GRASSES}

$\begin{array}{lrr}\text { AG SP } & 0.01 & 2 \\ \text { AG TR } & 0.03 & 2 \\ \text { BR IN } & 4.55 & 91 \\ \text { CA AU } & 0.86 & 26 \\ \text { EL IN } & 12.31 & 100 \\ \text { PH PR } & 0.07 & 4 \\ \text { PH PR } & 0 & 0 \\ \text { POPA } & 0.25 & 14 \\ \text { PO SP } & 0.10 & 7 \\ \text { POPR } & 0.07 & 4 \\ \text { UN GR } & 0.01 & 2\end{array}$

TOTAL GRASS

COVER

18.268

LICHENS, MOSSES, FERNS

$\begin{array}{lrr}\text { HY SP } & 24.19 & 63 \\ \text { PE AP } & 1.14 & 34\end{array}$


GRASSES

$\begin{array}{lcr}\text { AG TR } & 0 & 0 \\ \text { BR IN } & 7.14 & 93 \\ \text { CA AU } & 0.16 & 14 \\ \text { CA SP } & 0.02 & 2 \\ \text { EL IN } & 10.71 & 95 \\ \text { FE SP } & 0 & 0 \\ \text { POPA } & 0.17 & 6 \\ \text { PO SP } & 0.02 & 1 \\ \text { PO PR } & 0.07 & 3 \\ \text { UN GR } & 0.04 & 4\end{array}$

TOTAL GRASS

COVER

$18.60 \%$

$\begin{array}{lr}0.04 & 2 \\ 3.77 & 70 \\ 0.03 & 3 \\ 0.01 & 1 \\ 8.81 & 95 \\ 0.03 & 1 \\ 0.06 & 4 \\ 0.01 & 1 \\ 0 & 0 \\ 0 & 0\end{array}$

$\begin{array}{lc}0.02 & 1 \\ 5.59 & 81.5 \\ 0.095 & 8.5 \\ 0.015 & 1.5 \\ 9.76 & 95 \\ 0.015 & 0.5 \\ 0.115 & 5 \\ 0.015 & 1 \\ 0.035 & 1.5 \\ 0.02 & 2\end{array}$

12.768

15.688

\section{LICHENS, MOSSES, FERNS}

$\begin{array}{lccrccc}\text { CL SP } & 0 & 0 & 0.02 & 3 & 0.01 & 1.5 \\ \text { HY SP } & 66.19 & 99 & 52.23 & 91 & 59.21 & 95 \\ \text { PE AP } & 1.25 & 42 & 1.36 & 34 & 1.305 & 38 \\ \text { PL SC } & 0 & 0 & 0.02 & 1 & 0.01 & 0.5\end{array}$


Appendix 5

Changes in Density of Woody Plants Following Logging 
Table 1. Regeneration parameters for Year 26, scar ified and unscarified treatments of spruce, pine and mixedwood forests.

\begin{tabular}{|c|c|c|c|c|c|c|c|c|}
\hline \multirow{2}{*}{$\begin{array}{l}\text { REGENERATION } \\
\text { PARAMETERS }\end{array}$} & \multicolumn{2}{|c|}{$\underset{\text { Spruce }}{F} 0$} & \multirow[t]{2}{*}{$E$} & \multicolumn{2}{|c|}{$\begin{array}{ll}S & T \\
& \text { Pine }\end{array}$} & \multirow[t]{2}{*}{ Y } & \multicolumn{2}{|c|}{$P \underset{\text { Mixedwood }}{E}$} \\
\hline & SC & UN & & SC & UN & & SC & UN \\
\hline Stocking rate & 24 & 27 & & 15 & 12 & & 8 & 25 \\
\hline Density & 9.3 & 2.3 & & 2.3 & 1.3 & & 1.5 & 1.7 \\
\hline Multiple trees & 70 & 38 & & 28 & 19 & & 12 & 27 \\
\hline Mean height $(m)^{b}$ & 0.78 & 1.97 & & 6.17 & 4.63 & & 1.44 & 2.85 \\
\hline Mean height $(m)^{f}$ & 0.72 & 1.46 & & - & - & & 1.44 & 1.89 \\
\hline Growth rate bc & $0.05^{d}$ & $0.09^{d}$ & & $0.24^{e}$ & $0.18^{e}$ & & $0.09^{d}$ & $0.12^{d}$ \\
\hline$N$ (trees) & 200 & 200 & & 182 & 182 & & 148 & 148 \\
\hline
\end{tabular}

a Values in table are for spruce in the Spruce and Mixedwood forests and pine in the Pine forest. Percent of $0.89 \mathrm{~m}^{2}$ plots occupied by conifers.

b Based on systematically selected trees.

c Mean height divided by years since stand establishment.

d Growth rates based on Years $10-26=16$ years.

e Growth rates based on Years $1-26=26$ years.

$f$ Excluding residuals. 
Table 2. Density per hectere of coniferous (C) and deciduous (D) trees taller then $0.5 \mathrm{~m}$ in mature snd 32 yeer-pld cleer-cut blocks within three forest types, 1988.

\begin{tabular}{|c|c|c|c|c|c|c|c|c|c|}
\hline \multicolumn{2}{|l|}{ BLOCX } & \multicolumn{7}{|c|}{ HEIGHT CLASSES } & \multirow{3}{*}{$\begin{array}{l}12 \\
>10\end{array}$} \\
\hline \multicolumn{2}{|l|}{ AND TREE } & $4-5 * *$ & 6 & 7 & 8 & 9 & 10 & 11 & \\
\hline \multirow{2}{*}{\multicolumn{2}{|c|}{ TYPE* }} & $0.6-1 \mathrm{~m}$ & $1-2 m$ & $2-3 m$ & $3-4 m$ & $4-6 m$ & $6-8 m$ & $8-12 m$ & \\
\hline & & & & FIXED & 1000 FOQ & EST & & & \\
\hline \multirow[t]{3}{*}{ SC: } & C & 390 & 980 & 390 & 120 & 150 & 160 & 70 & 0 \\
\hline & D & 800 & 500 & 100 & 300 & 400 & 600 & 100 & 100 \\
\hline & $\mathbf{T}$ & 1190 & 1460 & 490 & 420 & $\mathbf{5 5 0}$ & 760 & 170 & 100 \\
\hline \multirow[t]{3}{*}{ UN-1: } & C & 126 & 208 & 138 & 88 & 178 & 68 & 80 & 7 \\
\hline & D & 400 & 700 & 200 & 300 & 100 & 100 & 0 & 0 \\
\hline & $T$ & 526 & 908 & 338 & 388 & 278 & 168 & 80 & 76 \\
\hline \multirow[t]{3}{*}{ UN-2: } & C & 190 & 562 & $\mathbf{5 5 0}$ & 454 & 536 & 384 & 292 & 138 \\
\hline & D & 200 & 300 & 200 & 300 & 200 & 100 & 400 & 100 \\
\hline & $\mathbf{T}$ & 398 & 862 & 750 & 754 & 736 & 484 & 692 & 238 \\
\hline \multirow[t]{3}{*}{ Avo. UN } & C & 162 & 385 & $344^{\circ}$ & 271 & 357 & 226 & 186 & 107 \\
\hline & D & 300 & 500 & 200 & 300 & 150 & 100 & 200 & 50 \\
\hline & $T$ & 462 & 865 & 544 & 571 & 507 & 326 & 386 & 157 \\
\hline \multirow[t]{4}{*}{ Mature } & C & 268 & 536 & 300 & 288 & 160 & 144 & 76 & 224 \\
\hline & D & - & - & - & - & - & - & - & - \\
\hline & $T$ & - & - & - & - & - & - & - & - \\
\hline & & & & 1006 & EPOLE PIO & & & & \\
\hline \multirow[t]{3}{*}{ SC-1: } & C & 4 & 10 & 48 & 100 & 220 & 656 & 876 & 30 \\
\hline & D & 900 & 1600 & 800 & 1100 & 700 & 300 & 100 & 0 \\
\hline & $T$ & 904 & 1610 & 848 & 1200 & 920 & 956 & 976 & 30 \\
\hline \multirow[t]{3}{*}{ SC-2: } & C & 0 & 4 & 10 & 26 & 110 & 372 & 214 & 12 \\
\hline & D & 800 & 1400 & 300 & 800 & 800 & 400 & 100 & 200 \\
\hline & $\mathbf{T}$ & 800 & 1404 & 310 & 826 & 910 & 772 & 314 & 212 \\
\hline \multirow[t]{3}{*}{ Ave. SC: } & C & 2 & 7 & 29 & 63 & 165 & 514 & 545 & 21 \\
\hline & 0 & 850 & 1500 & 600 & 950 & 750 & 350 & 100 & 100 \\
\hline & $T$ & 852 & 1507 & 629 & 1013 & 915 & 864 & 645 & 121 \\
\hline \multirow[t]{3}{*}{ UN-1: } & C & 22 & 20 & 66 & 96 & 90 & 452 & 214 & 40 \\
\hline & D & 400 & 800 & 800 & 700 & 300 & 0 & 0 & 100 \\
\hline & $\mathbf{T}$ & 422 & 820 & 866 & 796 & 390 & 452 & 214 & 148 \\
\hline UN-2: & C & 10 & 10 & 44 & 64 & 178 & 382 & 442 & 92 \\
\hline & D & 1300 & 600 & 800 & 600 & 200 & 300 & 0 & 0 \\
\hline & $T$ & 1310 & 610 & 844 & 664 & 378 & 682 & 442 & 92 \\
\hline Ave. UN: & C & 16 & 15 & 55 & 80 & 134 & 417 & 328 & 70 \\
\hline & D & 850 & 700 & 800 & 650 & 250 & 150 & 0 & 50 \\
\hline & $\mathbf{T}$ & 866 & 715 & 855 & 730 & 384 & 567 & 328 & 120 \\
\hline & & & & WAITE S & Prace Fo & AEST & & & \\
\hline SC-1: & C & 2950 & 1320 & 200 & 60 & 90 & 60 & 0 & 0 \\
\hline & D & 1500 & 3600 & 1900 & 1100 & 500 & 200 & 0 & 0 \\
\hline & $\mathbf{T}$ & 4450 & 4920 & 2100 & 1160 & 590 & 260 & 0 & 0 \\
\hline SC-2: & C & 1104 & 620 & 124 & 32 & 36 & 16 & 0 & 0 \\
\hline & D & 500 & 1000 & 700 & 100 & 200 & 300 & 0 & 0 \\
\hline & $\mathbf{T}$ & 1604 & 1620 & 824 & 132 & 236 & 316 & 0 & 0 \\
\hline Ave. SN: & C & 2027 & 970 & 162 & 46 & 63 & 38 & 0 & 0 \\
\hline & D & 1000 & 2300 & 1300 & 600 & 350 & 250 & 0 & 0 \\
\hline & $T$ & 3027 & 3270 & 1462 & 646 & 413 & 288 & 0 & 0 \\
\hline UN-1: & C & 280 & 400 & 144 & 148 & 84 & 88 & 64 & 20 \\
\hline & D & 1200 & 2200 & 1200 & 700 & 600 & 0 & 0 & 0 \\
\hline & $T$ & 1480 & 2600 & 1344 & 848 & 684 & 88 & 64 & 20 \\
\hline UN-2: & C & 864 & 1080 & 440 & 264 & 136 & 80 & 36 & 16 \\
\hline & D & 800 & 1600 & 300 & 200 & 100 & $300^{\prime}$ & 0 & 0 \\
\hline & $T$ & 1664 & 2680 & 740 & 464 & 236 & 380 & 36 & 16 \\
\hline Ave. UN & C & 572 & 740 & 292 & 206 & 110 & 84 & 50 & 18 \\
\hline & D & 1000 & 1900 & 750 & 450 & 350 & 150 & 0 & 0 \\
\hline & $T$ & 1572 & 2640 & 1042 & 656 & 460 & 234 & 50 & 18 \\
\hline Mature: & C & 184 & 252 & 144 & 144 & 112 & 132 & 224 & 548 \\
\hline & D & - & - & - & - & - & - & - & - \\
\hline & $T$ & - & - & - & - & - & - & - & - \\
\hline
\end{tabular}

* $\quad C=$ coniferous, $D=$ deciduous, $T=$ total

* for deciduous trees, only height class $5(70-100 \mathrm{~cm})$ wes teken; not class 4. 
118

Table 3. Tree and shrub densities (per ha) in mature and logged (Years 6, 26 and 32) forests.

\begin{tabular}{|c|c|c|c|c|c|c|c|}
\hline SPECIES & YEAR & WHIT & SPRUCE & $\angle 0 O S$ & E PINE & & 1000 \\
\hline & & $S C$ & UN & SC & UN & SC & UN \\
\hline Alnus crispes & $M$ & & 0 & & & & \\
\hline (Green Alder) & 6 & 0 & 0 & 176 & 232 & 0 & 0 \\
\hline & 26 & 0 & 0 & 2614 & 1868 & 0 & 0 \\
\hline & 32 & 0 & 0 & 2300 & 1400 & 0 & 0 \\
\hline Botula spo. & $M$ & & 17 & & 0 & & \\
\hline (Birch) & 6 & 67 & 133 & 0 & 0 & 0 & 0 \\
\hline & 26 & 209 & 51 & 0 & 0 & 0 & 0 \\
\hline & 32 & 200 & 250 & 0 & 0 & 0 & 0 \\
\hline Lonicars spp. & $M$ & & 24 & & 0 & & \\
\hline (Honeysuckie) & 6 & 148 & 465 & 17 & 17 & 462 & 1043 \\
\hline & 26 & 585 & 1119 & 0 & 52 & 1013 & 1707 \\
\hline & 32 & 350 & 1100 & 500 & 450 & 600 & 1700 \\
\hline Pices giauca & $M$ & & 99 & & & & \\
\hline (White & 6 & 363 & 1043 & 32 & 49 & 68 & 55 \\
\hline spruce) & 26 & 22355 & 6858 & 160 & 387 & 1333 & 4641 \\
\hline & 32 & 9479 & 4306 & 69 & 221 & 2340 & 2501 \\
\hline Pinus contorts & $M$ & & 0 & & 7 & & \\
\hline (Ladgepole & 6 & 0 & 0 & 3046 & 570 & 50 & 18 \\
\hline pine) & 26 & 0 & 0 & 3734 & 2187 & 426 & 266 \\
\hline & 32 & 0 & 0 & 1285 & 1051 & 790 & 72 \\
\hline Populus spp. & $M$ & & 9 & & 0 & & \\
\hline (Popler) & 6 & 3684 & 5125 & 1308 & 620 & 2277 & 1350 \\
\hline & 26 & 5079 & 4002 & 3565 & 702 & 3734 & 2560 \\
\hline & 32 & 4300 & 3600 & 3050 & 1450 & 4600 & 2200 \\
\hline Potentille & $M$ & & 77 & & 0 & & \\
\hline fruticosa & 6 & - & - & 0 & 0 & 0 & 0 \\
\hline (Shrubby & 26 & 639 & 1225 & 0 & 0 & 0 & 0 \\
\hline cinquefoil) & 32 & 800 & 1350 & 0 & 0 & 0 & 0 \\
\hline Rosa spp. & $M$ & & & & & & \\
\hline (Rosa) & 6 & 16431 & 20326 & 7840 & 8860 & 10368 & 11175 \\
\hline & 26 & 33023 & 39158 & 24914 & 25768 & 31316 & 29182 \\
\hline & 32 & 24350 & 40800 & 23950 & 22800 & 40600 & 40750 \\
\hline Solix Spp. & $M$ & & & & & & \\
\hline (willow) & 6 & 2600 & 4481 & 703 & 100 & 485 & 388 \\
\hline & 26 & 3947 & 3414 & 1333 & 533 & 426 & 426 \\
\hline & 32 & 4700 & 5000 & 1350 & 600 & 600 & 400 \\
\hline Shepeherdis & $M$ & & 28 & & 0 & & \\
\hline canadensis & 6 & 230 & 198 & 0 & 0 & 282 & 657 \\
\hline (Bufraloberry) & 26 & 852 & 852 & 0 & 0 & 373 & 533 \\
\hline & 32 & 1100 & 800 & 0 & 0 & 200 & 450 \\
\hline Virturnum & $M$ & & 37 & & & & 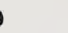 \\
\hline edule & 6 & 0 & 331 & 796 & 1821 & 0 & 0 \\
\hline (Low-bush & 26 & 746 & 318 & 4215 & 6085 & 0 & 0 \\
\hline crenberry) & 32 & 500 & 500 & 5700 & 7500 & 0 & 0 \\
\hline Others & $M$ & & 39 & & & & \\
\hline AMNL DIOX & 6 & & & & & & \\
\hline RUST SOSC & 26 & & & & & & \\
\hline SARA VACA & 32 & 100 & 1450 & 4200 & 2850 & 200 & 350 \\
\hline Totals & $M$ & & & & & & \\
\hline & 6 & 24484 & 31632 & 13956 & 12279 & 15574 & 17387 \\
\hline & 26 & 67018 & 57595 & 40646 & 34565 & 41020 & 43048 \\
\hline & 32 & 45879 & 59156 & 42404 & 38322 & 50130 & 48423 \\
\hline
\end{tabular}

* Also includes subalpine fir. 
Table 4a. Densities of coniferous and deciduous trees in mature and 32-year-old clear-cut forests, 1988.

\begin{tabular}{|c|c|c|c|c|c|c|c|c|}
\hline TREATMENT & $\begin{array}{l}\text { T R } \\
\text { Pine }\end{array}$ & $\begin{array}{c}\text { E } \\
\text { Spruce }\end{array}$ & $\hat{\text { Poplar }}^{\text {I N }}$ & $\underset{\text { Rose }}{M}$ I & $X \underset{\text { Willow }}{\mathbf{E}} \mathbf{W}$ & $\begin{array}{lll}\begin{array}{lll}0 & 0 & 0 \\
\text { Others }\end{array}\end{array}$ & $\begin{array}{c}\text { F O R } \\
\text { Deciduous } \\
\text { Total }\end{array}$ & $\begin{array}{c}\text { E S T T Tol } \\
\text { Tot }\end{array}$ \\
\hline $\begin{array}{l}S C-1 \\
\text { UN - 1 } \\
\text { UN - } 2 \\
\text { Ave. UN }\end{array}$ & $\begin{array}{r}790 \\
144 \\
12 \\
72\end{array}$ & $\begin{array}{l}2340 \\
1558 \\
3444 \\
2501\end{array}$ & $\begin{array}{l}4600 \\
2600 \\
1800 \\
2200\end{array}$ & $\begin{array}{l}40800 \\
30500 \\
51000 \\
40750\end{array}$ & $\begin{array}{l}600 \\
200 \\
600 \\
400\end{array}$ & $\begin{array}{l}1000 \\
1100 \\
3900 \\
2500\end{array}$ & $\begin{array}{l}47000 \\
34400 \\
57300 \\
45850\end{array}$ & $\begin{array}{l}50130 \\
36102 \\
60756 \\
48429\end{array}$ \\
\hline Mature & 36 & 2500 & $N 0$ & d $a$ & $t a$ & C 0 & $110 c$ & $t e c$ \\
\hline
\end{tabular}

TREES/HA IN LODGEPOLE PINE FOREST TREATMENT Pine Spruce Poplar Rose Willow Others Deciduous Total

\begin{tabular}{|c|c|c|c|c|c|c|c|c|}
\hline & & & & & & & Total & \\
\hline & 1859 & 98 & 2800 & 26400 & 2400 & 9200 & 40800 & 42757 \\
\hline$S C-2^{1}$ & 710 & 40 & 3300 & 21500 & 300 & 16200 & 41300 & 42050 \\
\hline Ave. SC & 1285 & 69 & 3050 & 23950 & 1350 & 12700 & 41050 & 42404 \\
\hline$U N-1^{2}$ & 1116 & 172 & 1600 & 21000 & 500 & 13900 & 37000 & 38288 \\
\hline$U N-2^{3}$ & 986 & 270 & 1300 & 24600 & 700 & 10500 & & 38356 \\
\hline e. UN & 1051 & 221 & 1450 & 22800 & 600 & 12200 & & 38322 \\
\hline ture & & & No & & data & & collex & \\
\hline
\end{tabular}

$1 A B L A=2$ trees/ho $2 A B L A=8$ trees/ha $3 A B L A=8$ trees/ha

TREES/HA IN WHITE SPRUCE FOREST TREATMENT Pine Spruce Poplar Rose Willow Others Deciduous Total

\begin{tabular}{|c|c|c|c|c|c|c|c|}
\hline \multirow{3}{*}{$\begin{array}{l}S C-1 \\
S C-2\end{array}$} & & & & & \multicolumn{3}{|c|}{100} \\
\hline & 14030 & 5600 & 33200 & 6900 & 3800 & 49500 & 63530 \\
\hline & 4928 & 3000 & 15500 & 2500 & 2300 & 23300 & 28228 \\
\hline e. SC & 9479 & 4300 & 24350 & 4700 & 3050 & 36400 & 45879 \\
\hline$v-1$ & 2028 & 4500 & 48100 & 1400 & 5500 & 59500 & 61528 \\
\hline UN - 2 & 6584 & 27 & 33500 & 8600 & 5400 & & 56784 \\
\hline 9. UN & 4306 & 3600 & 40800 & 5000 & 5450 & 54850 & 59156 \\
\hline ature & 2780 & $N 0$ & d a & $t \quad a$ & $C 0$ & 110 & 8 \\
\hline
\end{tabular}


Table 4b. Plant density of deciduous and coniferous woody species 26 years after logging in three forest types.

\begin{tabular}{|c|c|c|c|c|c|c|c|}
\hline \multirow[t]{2}{*}{ SPECIES* } & \multirow{2}{*}{$\begin{array}{l}\text { */Ha and } \\
\% \text { Comp }\end{array}$} & \multicolumn{2}{|c|}{ WHITE SPRUCE } & \multicolumn{2}{|c|}{ LODGEPOLE PINE } & \multicolumn{2}{|c|}{ MIXEDWOOD } \\
\hline & & SC & UN & SC & UN & SC & UN \\
\hline \multirow[t]{2}{*}{ ALCR } & $* / \mathrm{Ha}$ & 0 & 0 & 2614 & 1868 & 0 & 0 \\
\hline & \% Comp & 0 & 0 & 5.9 & 4.6 & 0 & 0 \\
\hline \multirow[t]{2}{*}{ AMAL } & $* / \mathrm{Ha}$ & 51 & 1225 & 0 & 106 & 266 & 266 \\
\hline & 8 Comp & 0.1 & 2.0 & 0 & 0.3 & 0.7 & 0.7 \\
\hline BEGL+ & $* / \mathrm{Ha}$ & 209 & 51 & 0 & 0 & 0 & 0 \\
\hline BEPA & $\%$ Comp & 0.3 & 0.1 & 0 & 0 & 0 & 0 \\
\hline LOOI+ & $* / \mathrm{Ha}$ & 585 & 1119 & 0 & 424 & 1013 & 1707 \\
\hline LOME & 8 Comp & 0.8 & 1.8 & 0 & 1.0 & 2.6 & 4.3 \\
\hline \multirow[t]{2}{*}{ PICO } & $* / \mathrm{Ha}$ & 0 & 0 & 3736 & 2186 & 425 & 266 \\
\hline & $\%$ Comp & 0 & 0 & 8.4 & 5.4 & 1.1 & 0.7 \\
\hline \multirow[t]{2}{*}{ PIGL } & $* / \mathrm{Ha}$ & 24558 & 7259 & 158 & 373 & 1334 & 4642 \\
\hline & 8 Comp & 34.9 & 11.9 & 0.4 & 0.9 & 3.4 & 11.6 \\
\hline \multirow[t]{2}{*}{ POBA } & $* / \mathrm{Ha}$ & 5070 & 4002 & 3256 & 639 & 425 & 479 \\
\hline & 8 Comp & 7.2 & 6.6 & 7.3 & 1.6 & 1.1 & 1.2 \\
\hline \multirow[t]{2}{*}{ POTR } & $* / \mathrm{Ha}$ & 0 & 0 & 533 & 51 & 3736 & 2562 \\
\hline & \% Comp & 0 & 0 & 1.2 & 0.1 & 9.5 & 6.4 \\
\hline \multirow[t]{2}{*}{ POFR } & $* / \mathrm{Ha}$ & 639 & 1225 & 0 & 0 & 0 & 0 \\
\hline & \% Comp & 0.9 & 2.0 & 0 & 0 & 0 & 0 \\
\hline \multirow[t]{2}{*}{ RIOX } & $* / \mathrm{Ha}$ & 0 & 0 & 1386 & 906 & 0 & 51 \\
\hline & 8 Comp & 0 & 0 & 3.1 & 2.2 & 0 & 0.1 \\
\hline \multirow[t]{2}{*}{ ROAC } & $* / \mathrm{Ha}$ & 33046 & 39187 & 24932 & 25786 & 31339 & 29204 \\
\hline & $\approx$ Comp & 47.0 & 64.5 & 55.9 & 63.5 & 79.5 & 72.7 \\
\hline \multirow[t]{2}{*}{ RUST } & $* / \mathrm{Ha}$ & 0 & 0 & 1386 & 1279 & 0 & 0 \\
\hline & $\%$ Comp & 0 & 0 & 3.1 & 3.1 & 0 & 0 \\
\hline \multirow[t]{2}{*}{ SASP } & $* / \mathrm{Ha}$ & 3948 & 3414 & 1334 & 533 & 425 & 425 \\
\hline & $\approx$ Comp & 5.6 & 5.6 & 3.0 & 1.3 & 1.1 & 1.1 \\
\hline \multirow[t]{2}{*}{ SHCA } & $* / \mathrm{Ha}$ & 852 & 852 & 0 & 0 & 373 & 533 \\
\hline & \% Comp & 1.2 & 1.4 & 0 & 0 & 1.0 & 1.3 \\
\hline \multirow[t]{2}{*}{ VIED } & $* / \mathrm{Ha}$ & 746 & 318 & 4215 & 6085 & 51 & 0 \\
\hline & $\%$ Comp & 1.1 & 0.5 & 9.5 & 15.0 & 0.1 & 0 \\
\hline \multirow[t]{2}{*}{ OTHERS } & $* / \mathrm{Ha}$ & 664 & 2104 & 1028 & 394 & 15 & 13 \\
\hline & \% Comp & 0.9 & 3.6 & 2.3 & 1.0 & $<0.1$ & $<0.1$ \\
\hline \multirow[t]{2}{*}{ TOTALS } & $* / \mathrm{Ha}$ & 70368 & 60756 & 44578 & 40630 & 39402 & 40148 \\
\hline & $\approx$ Comp & 100.0 & 100.0 & 100.0 & 100.0 & 100.0 & 100.0 \\
\hline
\end{tabular}

* See Appendix 2 for scientific and common names of symbols 
Table 5. Densities (per ha) of deciduous woody plants in mature forests and various age classes of clear-cuts of scarified (SC) and unscarified (UN) clear-cuts.

\begin{tabular}{|c|c|c|c|c|c|}
\hline Forest & Poplar & Rose & Willow & Others & $\begin{array}{c}\text { Deciduous } \\
\text { Total }\end{array}$ \\
\hline Age & SC UN & SC UN & SC UN & SC UN & SC UN \\
\hline
\end{tabular}

\section{WHITE SPRUCE FOREST}

\begin{tabular}{rrrrrrrrrrr}
\multicolumn{2}{c}{ Mature } & 717 & \multicolumn{2}{c}{13832} & 2450 & \multicolumn{2}{c}{30} & \multicolumn{1}{c}{17029} \\
1 & 1268 & 68 & 8165 & 8600 & 583 & 433 & 314 & 951 & 10330 & 10052 \\
6 & 3684 & 5125 & 16341 & 20326 & 2880 & 4481 & 1126 & 657 & 24121 & 30589 \\
9 & 10097 & 3472 & - & - & 8532 & 2389 & - & - & - & - \\
17 & 4748 & 3841 & 37771 & 47054 & 5121 & 5655 & 2079 & 3837 & 49719 & 60387 \\
26 & 5079 & 4002 & 33023 & 39158 & 3947 & 3414 & 2614 & 4163 & 44663 & 50737 \\
32 & 4300 & 2600 & 24350 & 40800 & 4700 & 5000 & 3050 & 5450 & 36400 & 54850
\end{tabular}

\section{LODGEPOLE PINE FOREST}

\begin{tabular}{lrrrrrrrrrr} 
Mature & \multicolumn{1}{c}{0} & \multicolumn{2}{c}{6082} & \multicolumn{2}{c}{100} & \multicolumn{2}{c}{391} & \multicolumn{2}{c}{6573} \\
1 & 0 & 0 & 5833 & 13550 & 0 & 432 & 848 & 952 & 6681 & 15350 \\
6 & 1308 & 620 & 7840 & 8860 & 703 & 100 & 1025 & 2080 & 10876 & 11660 \\
9 & 1062 & 1440 & - & - & 1865 & 2297 & - & - & - & - \\
17 & - & - & - & - & - & - & - & - & - & - \\
26 & 3565 & 702 & 24914 & 25768 & 1333 & 533 & 6940 & 4988 & 36752 & 31991 \\
32 & 3050 & 1450 & 23950 & 22800 & 1350 & 600 & 12700 & 12200 & 41050 & 37050
\end{tabular}

\section{MIXEDWOOD FOREST}

\begin{tabular}{crccccccccc} 
Mature & \multicolumn{2}{c}{582} & \multicolumn{2}{c}{8067} & \multicolumn{2}{c}{67} & & - & \multicolumn{2}{c}{8716} \\
1 & 20 & 1333 & 4020 & 16682 & 18 & 2600 & 394 & 7467 & 4455 & 28082 \\
6 & 2277 & 1350 & 10368 & 11175 & 485 & 388 & 2326 & 4401 & 15456 & 17314 \\
9 & 1531 & 4385 & - & - & 488 & 1807 & - & - & - & - \\
17 & - & - & - & - & - & - & - & - & - & - \\
26 & 3734 & 2560 & 31316 & 29182 & 426 & 426 & 3785 & 5973 & 39261 & 38141 \\
32 & 4600 & 2200 & 40800 & 40750 & 600 & 400 & 1000 & 2500 & 47000 & 45850
\end{tabular}


Table 6. Trends in poplar and willow densities (per ha) following logging.

\begin{tabular}{|c|c|c|c|c|c|c|}
\hline $\begin{array}{c}\text { FOREST } \\
\text { AGE }\end{array}$ & $\begin{array}{c}P \\
S C^{2}\end{array}$ & $\begin{array}{l}P L \\
U N^{2}\end{array}$ & $\begin{array}{l}\text { A } \quad R \\
\% \text { Diff }^{1}\end{array}$ & $S C^{W}$ & $\underset{U N}{L} \mathbf{L}$ & $\begin{array}{l}0 \mathrm{~W} \\
\% \text { Diff }\end{array}$ \\
\hline & \multicolumn{5}{|c|}{ WHITE SPRUCE FOREST } & \\
\hline Mature & \multicolumn{2}{|r|}{717} & & \multicolumn{2}{|c|}{2450} & \\
\hline 1 & 1268 & 68 & -95 & 583 & 433 & -26 \\
\hline 6 & 3684 & 5125 & +39 & 2880 & 4481 & +56 \\
\hline 9 & 10097 & 3472 & -66 & 8532 & 2389 & -72 \\
\hline 17 & 4748 & 3841 & -19 & 5121 & 5655 & +10 \\
\hline 26 & 5079 & 4002 & -21 & 3947 & 3414 & -14 \\
\hline 32 & 4300 & 3600 & -16 & 4700 & 5000 & +6 \\
\hline $\bar{x}$ & 4863 & 3351 & -31 & 4294 & 3562 & -17 \\
\hline
\end{tabular}

\section{LODGEPOLE PINE FOREST}

Mature

0

$\begin{array}{rrrr}1 & 0 & 0 & 0 \\ 6 & 1308 & 620 & -53 \\ 9 & 1062 & 1440 & +36 \\ 26 & 3565 & 702 & -80 \\ 32 & 3050 & 1450 & -52 \\ \overline{\mathbf{x}} & 1797 & 847 & -53\end{array}$

100

$\begin{array}{rrr}0 & 432 & +432 \\ 703 & 100 & -86 \\ 1865 & 2297 & +23 \\ 1333 & 533 & -60 \\ 1350 & 600 & -56 \\ 1050 & 792 & -25\end{array}$

Mature

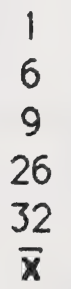

582

$\begin{array}{rrr}20 & 1333 & +6565 \\ 2277 & 1350 & -41 \\ 1531 & 4385 & +186 \\ 3734 & 2560 & -31 \\ 4600 & 2200 & -52 \\ 2432 & 2366 & -3\end{array}$

\section{MIXEDWOOD FOREST}

\section{7}

$\begin{array}{rrr}18 & 2600+14344 \\ 485 & 388 & -20 \\ 488 & 1807 & +270 \\ 426 & 426 & 0 \\ 600 & 400 & -33 \\ 403 & 1124 & +179\end{array}$
All Forests $\times 303$
2188
$-28$
1916
1826
$-5$ 
Table 7. Density (*/ha) of coniferous and deciduous trees $>5 \mathrm{~m}$ tall and those tall enough to provide inimalwinter thermal cover $(>2 \mathrm{~m})$ in 32 year-old clear-cuts and mature forests.

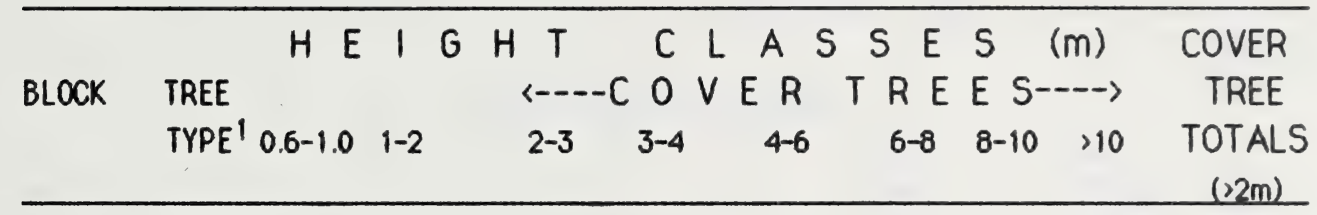

\section{MIXEDWOOD FOREST}

\begin{tabular}{|c|c|c|c|c|c|c|c|c|c|c|}
\hline $\begin{array}{l}32- \\
\text { Year } \\
\text { Scarified }\end{array}$ & $\begin{array}{l}C \\
D \\
T\end{array}$ & $\begin{array}{r}390 \\
800 \\
1190\end{array}$ & $\begin{array}{r}980 \\
500 \\
1480\end{array}$ & $\begin{array}{l}390 \\
100 \\
490\end{array}$ & $\begin{array}{l}120 \\
300 \\
420\end{array}$ & $\begin{array}{l}150 \\
400 \\
550\end{array}$ & $\begin{array}{l}160 \\
600 \\
760\end{array}$ & $\begin{array}{r}70 \\
100 \\
170\end{array}$ & $\begin{array}{r}0 \\
100 \\
100\end{array}$ & $\begin{array}{r}890 \\
1600 \\
2490\end{array}$ \\
\hline $\begin{array}{l}32- \\
\text { Year } \\
\text { Unscarified }\end{array}$ & $\begin{array}{l}C \\
D \\
T\end{array}$ & $\begin{array}{l}162 \\
300 \\
462\end{array}$ & $\begin{array}{l}385 \\
500 \\
885\end{array}$ & $\begin{array}{l}344 \\
200 \\
544\end{array}$ & $\begin{array}{l}271 \\
300 \\
571\end{array}$ & $\begin{array}{l}357 \\
150 \\
507\end{array}$ & $\begin{array}{l}226 \\
100 \\
326\end{array}$ & $\begin{array}{l}186 \\
200 \\
386\end{array}$ & $\begin{array}{r}107 \\
50 \\
157\end{array}$ & $\begin{array}{l}1491 \\
1000 \\
2491\end{array}$ \\
\hline Mature & $\begin{array}{l}C \\
D \\
T\end{array}$ & $\begin{array}{r}268 \\
- \\
-\end{array}$ & $\begin{array}{r}536 \\
- \\
-\end{array}$ & $\begin{array}{r}300 \\
- \\
-\end{array}$ & $\begin{array}{r}288 \\
- \\
-\end{array}$ & $\begin{array}{r}160 \\
- \\
-\end{array}$ & $\begin{array}{r}144 \\
- \\
-\end{array}$ & $\begin{array}{r}76 \\
- \\
-\end{array}$ & $\begin{array}{r}224 \\
- \\
-\end{array}$ & 1192 \\
\hline
\end{tabular}

\section{LODGEPOLE PINE FOREST}

$\begin{array}{lrrrrrrrrrr}32- & C & 2 & 7 & 29 & 63 & 165 & 514 & 545 & 21 & 1337 \\ \text { Year } & D & 850 & 1500 & 600 & 950 & 750 & 350 & 100 & 100 & 2850 \\ \text { Scarified } & T & 852 & 1507 & 629 & 1013 & 915 & 864 & 645 & 121 & 4187 \\ & & & & & & & & & & \\ 32- & C & 16 & 15 & 55 & 80 & 134 & 417 & 328 & 70 & 1084 \\ \text { Year } & D & 850 & 700 & 800 & 650 & 250 & 150 & 0 & 50 & 1900 \\ \text { Unscarified } & T & 866 & 715 & 855 & 730 & 384 & 567 & 328 & 120 & 2984\end{array}$

Mature

\section{WHITE SPRUCE FOREST}

\begin{tabular}{|c|c|c|c|c|c|c|c|c|c|}
\hline $\begin{array}{l}32- \\
\text { Year } \\
\text { Scarified }\end{array}$ & $\begin{array}{l}C \\
D \\
T\end{array}$ & $\begin{array}{rr}2027 & 970 \\
1000 & 2300 \\
3027 & 3270\end{array}$ & $\begin{array}{r}162 \\
1300 \\
1462\end{array}$ & $\begin{array}{r}46 \\
600 \\
646\end{array}$ & $\begin{array}{r}63 \\
350 \\
413\end{array}$ & $\begin{array}{r}38 \\
250 \\
288\end{array}$ & $\begin{array}{l}0 \\
0 \\
0\end{array}$ & $\begin{array}{l}0 \\
0 \\
0\end{array}$ & $\begin{array}{r}309 \\
2500 \\
2809\end{array}$ \\
\hline $\begin{array}{l}32- \\
\text { Year } \\
\text { Unscarified }\end{array}$ & $\begin{array}{l}C \\
D \\
T\end{array}$ & $\begin{array}{rr}572 & 740 \\
1000 & 1900 \\
1572 & 2640\end{array}$ & $\begin{array}{r}292 \\
750 \\
1042\end{array}$ & $\begin{array}{l}206 \\
450 \\
656\end{array}$ & $\begin{array}{l}110 \\
350 \\
460\end{array}$ & $\begin{array}{r}84 \\
150 \\
234\end{array}$ & $\begin{array}{r}50 \\
0 \\
50\end{array}$ & $\begin{array}{r}18 \\
0 \\
18\end{array}$ & $\begin{array}{r}760 \\
1700 \\
2460\end{array}$ \\
\hline Mature & C & 184 & 144 & 144 & 112 & 132 & 224 & 548 & 1304 \\
\hline
\end{tabular}


Appendix 6

Deciduous and Coniferous Heights in 32 Year-old Clear-cuts Within Three Forest Types 
Table 1. Mean heights $(\mathrm{m})$ of deciduous and coniferous trees* and shrubs* in 32 year-old clear-cuts within three forest types, 1988.

TREATMENT POPLAR ROSE WILLOW CONIFERS

\section{MIXEDWOOD FOREST}

SC - 1

2.48

0.18

0.53

0.42

UN -1

1.41

0.17

2.5

0.28

$-2$

4.12

0.17

1.77

0.33

AVE. UN

2.77

0.17

2.13

0.31

LODGEPOLE PINE FOREST

$\begin{array}{cllll}\text { SC - 1 } & 2.86 & 0.21 & 1.45 & 0.59 \\ -2 & 3.44 & 0.19 & 2.57 * & 0.61 \\ \text { AVE. SC } & 3.15 & 0.20 & 2.01 & 0.60 \\ \text { UN - 1 } & 2.37 & 0.20 & 2.32 & 0.45 \\ -2 & 2.32 & 0.26 & 3.31 & 0.51 \\ \text { AVE UN } & 2.35 & 0.23 & 2.82 & 0.48\end{array}$

MIXEDWOOD FOREST

SC -1

2.22

$-2$

1.69

0.23

0.95

0.60

0.13

1.11

0.46

AVE. SC

1.96

0.18

1.03

0.53

UN - 1

2.02

0.22

1.33

0.43

$-2$

1.90

0.19

0.46

0.35

AVE UN

1.96

0.21

0.90

0.39

* Deciduous height classes and means used in 1988 were:

Height

$\begin{array}{cc}\text { Range }(\mathrm{m}) & \text { Mean }(\mathrm{m}) \\ 0-.1 & .05 \\ .1-.2 & .15 \\ .2-.4 & .30 \\ .4-.7 & .55 \\ .7-1.0 & .85 \\ 1-2 & 1.5 \\ 2-3 & 2.5 \\ 3-4 & 3.5 \\ 4-6 & 5.0 \\ 6-8 & 7.0 \\ 8-10 & 9.0 \\ 10.1+ & 11.0\end{array}$


Table 2. Coniferous heights $(m)$ in three forest types, 32 years after logging.

\begin{tabular}{llcc}
\hline FOREST TYPE & & SCARIFIED & UNSCARIFIED \\
\hline Mixedwood Sample & 1 & 1.88 & 2.50 \\
& 2 & - & 3.97 \\
\multirow{3}{*}{ Pine Sample } & Ave. & 1.88 & 3.24 \\
& 1 & 7.38 & 5.72 \\
\multirow{2}{*}{ Spruce Sample } & 2 & 7.11 & 7.13 \\
& Ave. & 7.25 & 6.34 \\
& 2 & 0.64 & 1.86 \\
& Ave. & 0.71 & 1.08 \\
& & 0.68 & 1.47 \\
\hline
\end{tabular}


Table 3. Mean height $(m)$ of coniferous and deciduous woody plants in mature forests and in various age-classes of scar ified (SC) or unscarified(UN) clear-cuts.

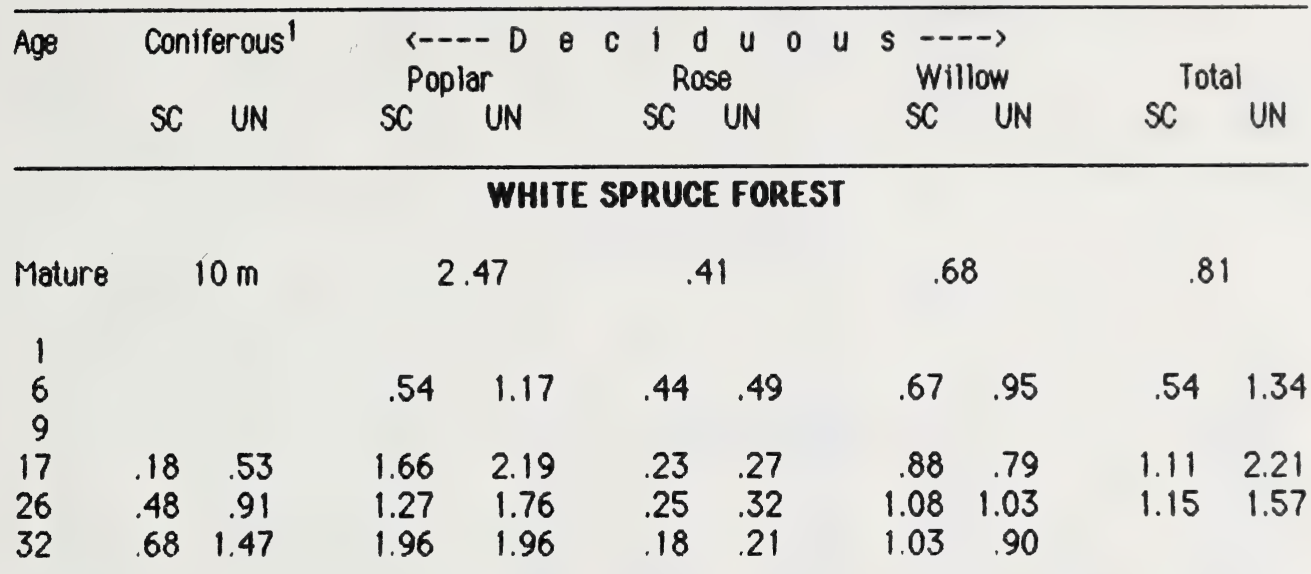

\section{LODOEPOLE PINE FOREST}

Mature $10 \mathrm{~m}$

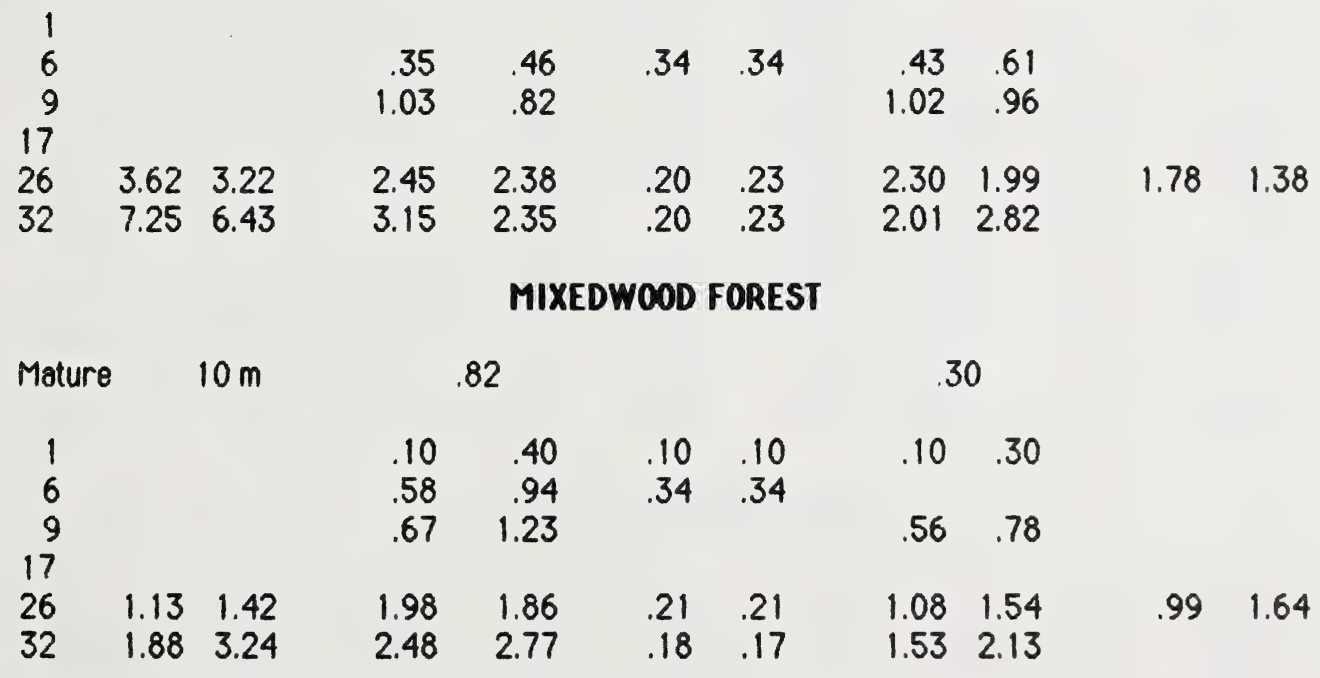

Spruce in spruce and mixedwood forest; pine in pine forest. (All trees included, not just dominants). 
Appendix 7

Coniferous Canopy Cover and Cervid Visibility in

32 Year-old Clear-cuts 
Table 1. Coniferous canopy closure values for mature forests and 32-year old clear cuts.

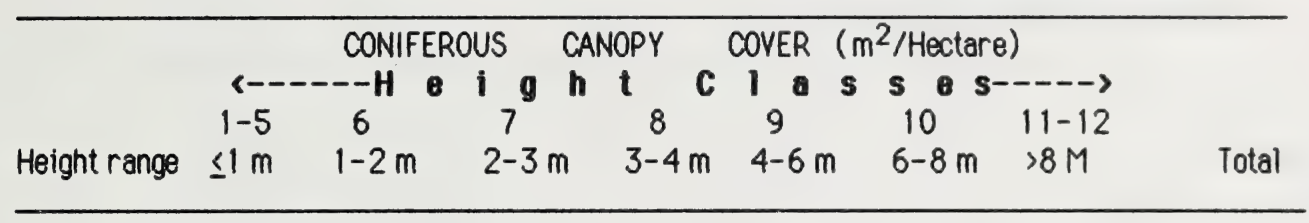

MIXEDWOOD FOREST

\begin{tabular}{|c|c|c|c|c|c|c|c|c|}
\hline \multicolumn{2}{|c|}{$\begin{array}{l}\text { Winter Cover }\langle-\mathrm{Nil} \rightarrow\rangle \\
\text { Quality }\end{array}$} & \multicolumn{2}{|c|}{$\langle---$ Poor ----〉 } & \multicolumn{2}{|c|}{$\langle---$ fair --- $\rangle$} & \multicolumn{2}{|c|}{ Good - Very Good } & \\
\hline SC & 713.9 & 555.2 & 221.0 & 68.0 & 85.0 & 90.7 & 39. & 1773.3 \\
\hline 81 & 7.1 & 5.5 & 2.2 & 0.7 & 0.8 & 0.1 & 0.40 & 17.7 \\
\hline UN -1 & 656.4 & 157.3 & 104.4 & 66.5 & 134.6 & 51.4 & 118.0 & 1288.6 \\
\hline 8 & 6.5 & 1.5 & 1.0 & 0.6 & 1.3 & 0.5 & 1.2 & 12.9 \\
\hline UN -2 & 1048.4 & 1091.1 & 1067.8 & 881.4 & 1040.6 & 745.5 & 834.8 & 6709.3 \\
\hline 8 & 10.5 & 11.0 & 10.7 & 8.8 & 10.4 & 7.5 & 8.3 & 67.1 \\
\hline Ave. UN & 852.4 & 624.2 & 586.0 & 473.9 & 587.6 & 398.4 & 476.4 & 3999.0 \\
\hline 8 & 8.5 & 6.2 & 5.8 & 4.7 & 5.9 & 4.0 & 4.7 & 40.0 \\
\hline Mature & 1117.0 & 741.0 & 414.7 & 398.1 & 221.2 & 199.1 & 414.7 & 3505.8 \\
\hline$\%$ & 11.2 & 7.4 & 4.1 & 4.0 & 2.2 & 2.0 & 4.1 & 35.0 \\
\hline
\end{tabular}

\section{LODGEPOLE PINE FOREST}

\begin{tabular}{lrrrrrrrr} 
SC-1 & 47.5 & 29.7 & 142.6 & 297. & 653.84 & 1949.6 & 2692.6 & 5813.4 \\
8 & 0.5 & 0.3 & 1.4 & 2.9 & 6.5 & 19.5 & 26.9 & 58.1 \\
SC-2 & 21.7 & 21.7 & 54.2 & 141.0 & 596.6 & 2017.7 & 1225.8 & 4078.8 \\
\% & \multicolumn{1}{c}{0.2} & 0.2 & 0.5 & 1.4 & 6.0 & 20.2 & 12.2 & 40.8 \\
Ave. SC & \multicolumn{1}{c}{33} & 25.71 & 98.45 & 219.1 & 625.2 & 1983.6 & 1959.2 & 4946.1 \\
\% & 0.3 & 0. & 0.98 & 2.2 & 6.2 & 19.4 & 19.6 & 49.4 \\
UN-1 & 400.5 & 59.8 & 197.2 & 286.9 & 866.7 & 1350.9 & 711.3 & 3873.3 \\
8 & 4.0 & 0.6 & 2.0 & 2.9 & 8.7 & 13.5 & 7.1 & 38.7 \\
UN 2 & 169.0 & 32.5 & 143.0 & 208.0 & 578.4 & 1241.3 & 1735.3 & 4107.5 \\
8 & 1.7 & 0.3 & 1.4 & 2.1 & 5.8 & 12.4 & 17.3 & 41.1 \\
Ave. UN & 284.7 & 46.1 & 170.1 & 247.4 & 722.6 & 1296.1 & 1223.3 & 3990.4 \\
\& & 2.8 & 0. & 1.70 & 2.5 & 7.2 & 12.9 & 12.2 & 39.9
\end{tabular}

\section{WHITE SPRUCE FOREST}

$\begin{array}{lrrrrrrrr}\text { SC 1 } & 1654.1 & 177.5 & 26.9 & 8.1 & 12.1 & 8.1 & 0 & 1886.7 \\ \text { 8 } & 16.5 & 1.8 & 0.3 & 0.1 & 0.1 & 0.1 & 0 & 18.9 \\ \text { SC -2 } & 710.7 & 107.5 & 21.5 & 5.5 & 6.2 & 2.8 & 0 & 854.2 \\ \text { 8 } & 7.1 & 1.1 & 0.2 & 0.0 & 0.1 & 0.0 & 0 & 8.5 \\ \text { Ave. SC } & 1182.4 & 142.5 & 24.2 & 6.8 & 9.2 & 5.4 & 0 & 1370.5 \\ \text { \% } & 11.8 & 1.4 & 0.2 & 0.1 & 0.1 & 0.1 & 0 & 13.7 \\ \text { UN 1 } & 815.5 & 302.0 & 108.7 & 111.7 & 63.4 & 66.4 & 63.4 & 1531.3 \\ \text { \% } & 8.2 & 3.0 & 1.1 & 1.1 & 0.6 & 0.6 & 0.6 & 15.3 \\ \text { UN 2 } & 1159.5 & 276.3 & 112.6 & 67.5 & 34.8 & 20.5 & 13.3 & 1684.5 \\ \text { 8 } & 11.6 & 2.7 & 1.1 & 0.7 & 0.3 & 0.2 & 0.1 & 16.8 \\ \text { Ave. UN } & 987.5 & 289.2 & 110.6 & 89.6 & 49.1 & 43.4 & 38.4 & 1607.9 \\ \text { 8 } & 9.9 & 2.9 & 1.1 & 0.9 & 0.5 & 0.4 & 0.4 & 16.1 \\ \text { Mature } & 1959.2 & 403.4 & 230.5 & 230.5 & 179.3 & 211.3 & 1235.7 & 4449.7 \\ \text { \% } & 19.6 & 4.0 & 2.3 & 2.3 & 1.8 & 2.1 & 12.4 & 44.5\end{array}$


Table 2. Visibility values at five heights above ground in mature and 32 year-old clear-cut blocks.

\begin{tabular}{lccccccccccc}
\hline & $H$ & $E$ & $G$ & $H$ & $T$ & $C$ & $A$ & $S$ & $S$ & $E$ & $S$ \\
FOREST & 1 & 2 & & & & 4 & 5 & Aves. \\
BLOCK & $(1.5 \mathrm{~m})$ & $(.5-1.0 \mathrm{~m})$ & $(1.0-1.5 \mathrm{~m})$ & $(1.5-2 . \mathrm{m})$ & $(2.0-2.5 \mathrm{~m})$ & $(0-2.5 \mathrm{~m})$ \\
\hline
\end{tabular}

\section{MIXEDWOOD FOREST}

$\begin{array}{lllllll}\mathrm{SC}^{1} & 49.4 & 63.4 & 72.0 & 69.4 & 68.0 & 64.4 \\ \mathrm{UN}^{2} 2^{2} & 16.6 & 26.0 & 26.0 & 27.4 & 26.6 & 24.5 \\ \text { Mature } & 16.0 & 36.0 & 45.4 & 45.4 & 40.6 & 36.7\end{array}$

\section{LODGEPOLE PINE FOREST}

$\begin{array}{lllllll}\text { SC-1 } & 10.6 & 23.5 & 29.4 & 30.0 & 33.4 & \\ \text { SC-2 } & 10.6 & 17.4 & 23.4 & 26.6 & 25.4 & \\ \text { Ave. SC } & 10.6 & 20.4 & 26.4 & 28.3 & 29.4 & 23.0 \\ \text { UN-1 } & 16.6 & 25.4 & 22.6 & 19.4 & 20.6 & \\ \text { UN-2 } & 13.4 & 22.0 & 22.6 & 23.4 & 22.6 & \\ \text { Ave. UN } & 15.0 & 23.7 & 22.6 & 21.4 & 21.6 & 20.9\end{array}$

WHITE SPRUCE FOREST

$\begin{array}{lllllll}\text { SC-1 } & 13.4 & 30.0 & 38.0 & 48.6 & 58.6 & \\ \text { SC-2 } & 28.0 & 39.4 & 45.4 & 51.4 & 50.6 & \\ \text { Ave. SC } & 20.7 & 34.7 & 41.7 & 50.0 & 54.6 & 40.3 \\ \text { UN-1 } & 16.6 & 26.6 & 30.6 & 36.6 & 41.4 & \\ \text { UN-2 } & 14.6 & 28.0 & 38.0 & 48.0 & 47.4 & \\ \text { Ave. UN } & 15.6 & 27.3 & 34.3 & 42.3 & 44.4 & 32.8 \\ \text { Mature } & 18.6 & 31.4 & 41.4 & 44.6 & 51.4 & 37.5\end{array}$

AVES. OF ALL THREE FORESTS

$\begin{array}{lllllll}\text { SC } & 22.4 & 34.7 & 41.6 & 45.2 & 47.2 & 38.2 \\ \text { UN } & 15.6 & 25.6 & 28.0 & 31.0 & 31.7 & 26.4 \\ \text { Mature } & 17.3 & 33.7 & 43.4 & 45.0 & 46.0 & 37.1\end{array}$

ISC = Scarified clear-cut

2 UN = Unscarif ied clear-cut, UN-2 is unscarified Sample 2 as Sample 1 is being lost to gravel pit operations. 
Appendix 8

Wildlife Abundance (Winter vs Summer)

Following Logging 


\section{Big Game}

\begin{tabular}{|c|c|c|c|c|c|c|}
\hline YEAR & FOREST & BLOCK & \multirow{2}{*}{\multicolumn{2}{|c|}{$\frac{\frac{\text { DENSITY } / \mathrm{Km}^{2}}{1.5}}{\frac{\text { Summer }}{\text { Winter }}}$}} & \multicolumn{2}{|c|}{ PELLET GROUPS/Ha } \\
\hline Mature & Spruce & Mature & & & Scarified & $\frac{\text { Unscarifies }}{17}$ \\
\hline 1 & $"$ & scar. & 0.8 & 0 & 35 & 17 \\
\hline 5 & " & $"$ & 3.5 & 0 & 35 & 50 \\
\hline 9 & " & $"$ & - & - & 75 & 15 \\
\hline 17 & " & $"$ & 10.0 & 0.2 & 162 & 1025 \\
\hline 26 & " & $"$ & - & - & 405 & 400 \\
\hline 32 & $"$ & $"$ & - & - & 210 & 446 \\
\hline
\end{tabular}

During Years $1-5$, in summer, most use in spruce clear-cuts was by deer plus light use by moose in the unscarified block. By Year $9,40 \%$ of use was winter use by deer and elk with most use still in the unscarified block.

Winter use declined compared with summer use in Year 17, apparently because residual mature spruce blocks, which formerly covered one-third of the area, were removed in Years 12 and 13.

Theoretically, browse forage in the 17 year-old scarified block could support 32 moose or 94 elk or 336 deer $/ \mathrm{km}^{2}$ annually. In fact, summer densities were 10 big game $/ \mathrm{km}^{2}$ ( 6 deer, 1 moose, 3 elk). Winter densities were only $0.2 / \mathrm{km}^{2}$ for big game.

Big game use of the unscarified block averaged 2.7 times greater than that in the scarified block, during Years 1-17.

During Year 32 , big game abundance, based on pellet-group counts, was $112,-6$ and $470 \%$ greater in unscarified spruce, pine and mixedwood clear-cuts than in respective scarifled blocks (Table 2). Big game use was greatest in spruce, then in pine and least in mixedwood clear-cuts with most use by deer in both summer and winter.

in the 285 ha lodgepole pine clear-cut, big game use during Years 1-6 was 2.4 times greater in unscarified than scarified clear-cuts. Most use was confined to a $25 \%$ perimeter area adjacent to the uncut forest. Only summer use occurred in Year 6 with elk and deer tracks common in both clear-cuts. In Year 9, use was 2.4 times greater than Year 6 and this use was by moose. There was 1.7 times more use in unscarified than in scarified blocks and $87 \%$ of the use was during winter. One herd of $4-6$ white-tailed deer summered within the area where a mature grove of balsam poplar remained in the scarified block. One herd of four elk ( 2 cows +2 bulls) plus another of four ( 3 cows, 1 calf) used the upper half of the unscarified block. The big game density was estimated at $4 / \mathrm{km}^{2}$ for 
the summer season. In Year 25, most summer use was of deer and one herd of 5-10 elk was flushed from thick pine and alder growth of the scarified block. Pellet groups indicated that winter use by moose exceeded summer use. In November there was one herd of 4-5 mule deer and no white-tailed deer near the above grove of balsam poplar. No elk or moose were using clear-cuts during that month. In summer of Year 26, no pellet groups were found on the plots but three fresh moose beds were found in the upper half of the unscarified block. Some deer use occurred in the vicinity of the grove of balsam poplar. No sign of elk was observed. In January 1983 (Year 27), the following densities of big game tracks/ha were observed: 7 deer, 3 moose in scarified; 3 deer, 5 moose in unscarified and 0 deer, 0 moose in mature blocks. A helicopter survey in March 1983 revealed 2 adult moose in the scarified block.

Within the mixedwood forest, most big game use during Years 1-6 was summer use by deer. By Year 7 big game use was 7.4 and 12.6 times greater than in the spruce and pine clear-cuts, respectively. Most use was by deer and elk plus a small amount of winter use by moose. The mature, residual seed blocks $(100 \times 100 \mathrm{~m})$ provided important security and winter shelter cover for all three species. In Year $9,57 \%$ of big game use within mature seed blocks was by elk whereas elk use comprised 72 and $78 \%$ of big game use in scarified and unscarified blocks, respectively. Deer comprised $16 \%$ of big game use in the seed blocks compared with 8 and $17 \%$ in scarified and unscarified blocks. Moose comprised $27 \%$ of big game use in the seed blocks compared with 20 and $6 \%$ scarified and unscarified blocks, respectively. Deer comprised $16 \%$ of big game use in the seed blocks compared with 8 and $17 \%$ in scarified and unscarified blocks. Thus elk use, in decreasing order, was: unscarified, scarified and seed blocks. Deer use was unscarified, seed blocks and scarified while moose use was seed blocks, scarified and unscarified. In the scarified block, big game use was greatest within $6 \mathrm{~m}$ of seed blocks whereas use was more extensive in the unscarified block. In the summer of Year 25, a small herd of elk and 5 or 6 deer used the unscarified and to a lesser extent the scarified blocks. Gravel pit and other human activities kept big game populations far below the range carrying capacity of the clear-cuts. Winter use was negligible but deer and elk attempted to use the clear-cuts in spring to use the new grass and forb growth. In the summer of Year 26, one herd of 4+ elk were seen in the unscarified block and light deer use also existed. No big game pellet groups occurred on the plots indicating light big game use. Within a week of the opening of the September hunting season, the elk had 
moved north across the Athabasca River and deer had vacated the clear-cuts. In January and March of Year 27, no big game were using the clear-cuts.

\section{Grouse}

In spruce clear-cuts, spruce grouse disappeared following logging but small numbers of nesting blue grouse used the scarified block during Years 3-25 in summer. A light population of ruffed grouse used both clear-cut blocks but did not become common until Year 26. By Year 32, they were common in the scarifled block.

In pine clear-cuts, all grouse disappeared following logging and were non-existent during Years 1-26. In Year 32, spruce grouse were common in both clear-cuts, especially the scarified block while ruffed grouse occurred only around the perimeter of the young pine forest.

In mixedwood clear-cuts, ruffed grouse remained and spruce grouse disappeared from the unscarified block following logging. Both disappeared from the scarified block. By Year 26, ruffed grouse were present in both clear-cuts during winter but were only one-third as abundant as grouse in the adjacent mature block.

\section{Furbearing Mammals}

Their numbers were depleted following logging, except weasels, coyotes and lynx which responded to an increased density of mice and hares. Furbearers remained scarce to Year 17. By Year 26, red squirrels were common in all unscarified blocks but not in scarified blocks. For the three forests, the abundance of red squirrels was 31 and 4 times greater in the mature than in scarified and unscarified blocks, respectively. Considering five furbearers (coyote, wolf, lynx, weasel, squirrel), their abundance was 17 and 3 times greater in mature than in scarified and unscarified blocks. They were 8.6 and 7.0 times greater in the mixedwood than in spruce and pine forest blocks at Year 27.

\section{Snowshoe Hares}

Their numbers remained low during Years 1-10 but were more abundant in unscarified than scarified blocks in spruce and mixedwood forests. In Year 25 (1981), their numbers were high in all three forests but especially in mixedwood and pine forest blocks. Browsing of coniferous and deciduous woody species indicated high abundance during the previous 2 or 3 years. In January 1983 (Year 27), highest densities were in mixedwood blocks where abundance values (track counts) were 2.4 
and 1.1 times greater than in spruce and pine blocks. Highest densities were in unscarified blocks except for the spruce forest where the density was highest in the mature block.

Hares girdled 66.5 and $48.0 \%$ of pine in scarified and unscarified blocks of the pine forest in Year 26. Girdling of conifers was not noticeable within the spruce and mixedwood clear-cuts.

Table 1. Winter abundance of wildlife within mature and 26 year-old scarified and unscarified clear-cut blocks in three forest types, January 1983.

DENSITIES* OF SETS OF TRACKS/HA

BLOCKS BIGGAME CARNIVORES RODENTS BIRDS

Deer Moose Coyote Wolf Lynx Weasel Hare Squirrel Mice $\begin{gathered}\text { Ruffed } \\ \text { Grouse TOTALS }\end{gathered}$

\section{CAMP I (WHITE SPRUCE)}

$\begin{array}{lrrrrrrrrrrr}\text { Mature } & 0 & 0 & 33 & 0 & 0 & 0 & 923 & 31 & 25 & 0 & 1012 \\ \text { Unscarified } & 27 & 0 & 29 & 0 & 15 & 10 & 471 & 56 & 537 & 0 & 1145 \\ \text { Scarified } & 10 & 0 & 8 & 0 & 0 & 4 & 218 & 0 & 142 & 31 & 413\end{array}$

\section{CAMP 5 (LODGEPOLE PINE)}

\begin{tabular}{|c|c|c|c|c|c|c|c|c|c|c|c|}
\hline Mature & 0 & 0 & 15 & 0 & 4 & 0 & 687 & 152 & 0 & 0 & 858 \\
\hline Unscarified & 2 & 4 & 23 & 2 & 0 & 0 & 1396 & 21 & 0 & 0 & 1448 \\
\hline Scarified & 8 & 2 & 12 & 0 & 0 & 0 & 1341 & 0 & 0 & 0 & 1363 \\
\hline \multicolumn{12}{|c|}{ CAMP 9 (MIXEDWOOD) } \\
\hline Mature & 0 & 0 & 58 & 0 & 0 & 0 & 1481 & 1179 & 4 & 25 & 2747 \\
\hline Unscarified & 0 & 0 & 67 & 0 & 0 & 2 & 2191 & 246 & 10 & 8 & 2524 \\
\hline Scarifled & 10 & 0 & 15 & 0 & 0 & 2 & 181 & 44 & 2 & 6 & 250 \\
\hline
\end{tabular}

* The sample size was two belt-transects $(4 \mathrm{~m} \times 300 \mathrm{~m})=2400 \mathrm{~m}^{2}$ or 0.24 ha. 2 samples $=0.48 \mathrm{ha}$.

Values $/$ ha $=$ total for Samples $1+2 \times 2.083$. 
Table 2. Winter versus summer big game abundance following logging in three forest types.

\begin{tabular}{|c|c|c|c|c|c|c|c|c|c|}
\hline \multirow{3}{*}{ YEAR } & \multirow[t]{3}{*}{ FOREST TYPE } & \multicolumn{2}{|c|}{$P E L L E T$} & \multirow{3}{*}{$\begin{array}{l}G R \\
E L\end{array}$} & \multirow{3}{*}{$\begin{array}{llll}R & 0 & \text { U P } \\
& \\
K & \\
U N\end{array}$} & \multirow{2}{*}{\multicolumn{2}{|c|}{$\begin{array}{l}\text { SPER } \\
M O O S E\end{array}$}} & \multirow{2}{*}{\multicolumn{2}{|c|}{$\begin{array}{r}\text { HECTA } \\
\text { TOTALS }\end{array}$}} \\
\hline & & \multicolumn{2}{|c|}{$D E E R$} & & & & & & \\
\hline & & $S C^{*}$ & UN * & & & SC & UN & $\mathrm{SC}$ & UN \\
\hline \multirow[t]{3}{*}{1} & Mixedwood & $0 / 0$ & $0 / 17^{\sqrt{ }}$ & $0 / 0$ & $0 / 0$ & $0 / 0$ & $0 / 0$ & $0 / 0$ & $0 / 17$ \\
\hline & Pine & $0 / 0$ & $0 / 0$ & $0 / 0$ & $0 / 17$ & $0 / 17$ & $0 / 32$ & $0 / 17$ & $0 / 50$ \\
\hline & Spruce & $0 / 17$ & $0 / 0$ & $0 / 17$ & $0 / 0$ & $0 / 0$ & $0 / 17$ & $0 / 35$ & $0 / 17$ \\
\hline \multirow[t]{3}{*}{6} & Mixedwood & $50 / 17$ & $17 / 50$ & $250 / 50$ & $132 / 17$ & $0 / 0$ & $17 / 0$ & $300 / 67$ & $167 / 67$ \\
\hline & Pine & $0 / 0$ & $0 / 0$ & $0 / 17$ & $0 / 32$ & $0 / 0$ & $0 / 0$ & $0 / 17$ & $0 / 32$ \\
\hline & Spruce & $0 / 17$ & $0 / 32$ & $0 / 0$ & $0 / 17$ & 1710 & $0 / 0$ & $17 / 17$ & $0 / 50$ \\
\hline \multirow[t]{3}{*}{9} & Mixedwood & $15 / 15$ & $45 / 0$ & $242 / 32$ & $182 / 32$ & $75 / 0$ & $15 / 0$ & $332 / 45$ & $242 / 30$ \\
\hline & Pine & $0 / 0$ & $0 / 0$ & $0 / 0$ & $0 / 0$ & $45 / 0$ & $60 / 15$ & $45 / 0$ & $60 / 15$ \\
\hline & Spruce & $30 / 0$ & $0 / 0$ & $15 / 0$ & $0 / 15$ & $30 / 0$ & $0 / 0$ & $75 / 0$ & $0 / 15$ \\
\hline \multirow[t]{3}{*}{17} & Mixedwood & - & - & - & - & - & - & - & - \\
\hline & Pine & - & - & - & - & - & - & - & - \\
\hline & Spruce & $55 / 55$ & $325 / 270$ & $0 / 55$ & $300 / 107$ & 0 & 0 & $55 / 110$ & $625 / 377$ \\
\hline \multirow[t]{3}{*}{26} & Mixedw & $0 / 0$ & $0 / 0$ & $0 / 0$ & $0 / 0$ & $0 / 0$ & $0 / 0$ & $0 / 0$ & $0 / 0$ \\
\hline & Pine & $0 / 0$ & $0 / 0$ & $0 / 0$ & $0 / 0$ & $0 / 0$ & $0 / 0$ & $0 / 0$ & $0 / 0$ \\
\hline & Spruce & $162 / 0$ & $265 / 0$ & $135 / 0$ & $135 / 0$ & $107 / 0$ & $0 / 0$ & $404 / 0$ & $400 / 0$ \\
\hline \multirow[t]{3}{*}{32} & Mixedwood & $0 / 20$ & $92 / 12$ & $0 / 0$ & $10 / 0$ & $0 / 0$ & $0 / 0$ & $0 / 20$ & $102 / 12$ \\
\hline & Pine & $60 / 65$ & $102 / 38$ & $5 / 5$ & $0 / 0$ & $25 / 20$ & $24 / 6$ & $90 / 90$ & $126 / 44$ \\
\hline & Spruce & $106 / 54$ & $294 / 112$ & $26 / 24$ & $25 / 15$ & $0 / 0$ & $0 / 0$ & $132 / 78$ & $319 / 127$ \\
\hline
\end{tabular}

* $\mathrm{SC}=$ Scarified, UN $=$ Unscarified

$0=$ Winter, $17=$ Summer 
Table 3. Big game sign occurrence for each species using Wilcoxan signed-rank tests in scar ified (SC) and unscarified (UN) clear-cuts during Years 1-27.

\begin{tabular}{|c|c|c|c|c|c|c|}
\hline Species & $\Sigma S C$ & $\Sigma U N$ & ESC ranks & ¿UN ranks & ¿Prob.' & $\mathrm{N}^{2}$ \\
\hline \multicolumn{7}{|c|}{ WHITE SPRUCE FOREST } \\
\hline Deer & 48 & 100 & 30 & 64 & .005 & 24 \\
\hline Elk & 6 & 35 & 6 & 29 & .005 & 13 \\
\hline Moose & 4 & 10 & 4 & 10 & .010 & 9 \\
\hline \multicolumn{7}{|c|}{ LODGEPOLE PINE FOREST } \\
\hline Deer & 4 & 21 & 3 & 13 & .047 & 6 \\
\hline Elk & 1 & 8 & 1 & 6 & .016 & 6 \\
\hline Moose & 12 & 12 & 4 & 12 & .010 & 10 \\
\hline \multicolumn{7}{|c|}{ MIXEDWOOD FOREST } \\
\hline Deer & 1 & 11 & 1 & 7 & .016 & 6 \\
\hline Elk & 17 & 24 & 12 & 19 & .027 & 11 \\
\hline Moose & 0 & 1 & 0 & 1 & * & 1 \\
\hline $\begin{array}{l}\text { Samp } \\
\text { SC Su } \\
\text { UN SU } \\
\text { SC ra } \\
\text { UN ra }\end{array}$ & insu & $\begin{array}{l}\text { or tes } \\
\text { ces (s } \\
\text { cces ( } \\
\text { ank di }\end{array}$ & $\begin{array}{l}\text { es (scarifi } \\
\text { es (unscar }\end{array}$ & \multicolumn{3}{|c|}{$\begin{array}{l}\text { IProbability values }<.05 \text { are significant. } \\
2 \text { Number of surveys where sign was present }\end{array}$} \\
\hline
\end{tabular}

Table 4. Total big game sign occurrence using Wilcoxan signed-rank tests in scarified (SC) and unscarified clear-cuts for three time periods (Years1-9, 17, 26-27).

\begin{tabular}{|c|c|c|c|c|c|c|}
\hline Years After & $\Sigma S C$ & $\Sigma U N$ & ¿SC ranks & ¿UN ranks & ¿Prob. & $N^{1}$ \\
\hline \multicolumn{7}{|c|}{ WHITE SPRUCE FOREST } \\
\hline $1-9$ & 13 & 50 & 13 & 44 & .004 & 14 \\
\hline 17 & 0 & 38 & 0 & 6 & .060 & 3 \\
\hline $26-27$ & 18 & 18 & 10 & 12 & $2.01 \mathrm{nsd}$ & 7 \\
\hline \multicolumn{7}{|c|}{ LODGEPOLE PINE FOREST } \\
\hline $1-9$ & 0 & 5 & 0 & 5 & .060 & 3 \\
\hline 17 & - & - & - & - & - & - \\
\hline $26-27$ & 11 & 30 & 7 & 22 & .055 & 8 \\
\hline \multicolumn{7}{|c|}{ MIXEDWOOD FOREST } \\
\hline $1-9$ & 12 & 9 & 5 & 4 & $2.10 \mathrm{nsd}$ & 4 \\
\hline 17 & - & - & - & - & - & - \\
\hline $26-27$ & 3 & 26 & 2 & 16 & .016 & 7 \\
\hline
\end{tabular}

i No sampling conducted.

1 Number of surveys where sign was present.

nsd no significant difference. 
Appendix 9

Browse Forage Production In 32 Year-old Clear-cuts, 1988 
Table 1. Browse forage production (gms/20 m2)* in 32 year-old clear-cuts, 1988.

\begin{tabular}{|c|c|c|c|c|c|c|c|}
\hline $\begin{array}{l}\text { BLOCK GREEN } \\
\text { SAMPLE or }\end{array}$ & WILLOW & POPLAR & ROSE & $\begin{array}{l}\text { HONEY- } \\
\text { SUCKLE }\end{array}$ & BIRCH & $\begin{array}{l}\text { LOW-BUSH } \\
\text { CRANBERRY }\end{array}$ & OTHERS TOTALS \\
\hline DRY & $L^{* *} S^{* *}$ & $L$ & $S$ & L S & s & L $\quad S$ & $L$ \\
\hline
\end{tabular}

\section{WHITE SPRUCE FOREST}

\begin{tabular}{|c|c|c|c|c|c|c|c|c|c|c|c|c|c|c|c|c|}
\hline \multirow[b]{2}{*}{ SC-1 } & & & & & & & & & & & & & \multicolumn{4}{|c|}{ AMAL } \\
\hline & GR & 695 & 589 & 599 & 597 & 508 & 360 & & & 180 & 140 & 54 & 49 & 0 & 0 & \\
\hline & DR & 313 & 377 & 258 & 400 & 234 & 252 & & & 81 & 91 & 23 & 32 & 0 & 0 & \\
\hline$S C-2$ & GR & 795 & 866 & 583 & 486 & 99 & 50 & & & 0 & 0 & 2 & 2 & 0 & 0 & \\
\hline & DR & 358 & 554 & 251 & 326 & 46 & 35 & & & 0 & 0 & 1 & 1 & 0 & 0 & \\
\hline SC-Ave & GR & 745 & 727 & 591 & 541 & 303 & 205 & & & 90 & 70 & 28 & 25 & 0 & 0 & (3325) \\
\hline & DR & 335 & 465 & 254 & 363 & 140 & 143 & & & 40 & 45 & 12 & 16 & 0 & 0 & (1813) \\
\hline UN-Ave & $G R$ & 436 & 371 & 365 & 359 & 217 & 193 & 5 & 8 & 35 & 40 & 69 & 91 & 330 & 373 & \\
\hline & $D R$ & 196 & 237 & 157 & 241 & 100 & 135 & 2 & 5 & 16 & 26 & 30 & 60 & 142 & 246 & \\
\hline UN-2 & $G R$ & 1038 & 1085 & 410 & 325 & 152 & 123 & 4 & 6 & 15 & 20 & 13 & 13 & 0 & 0 & \\
\hline & DR & 467 & 694 & 176 & 218 & 70 & 86 & 2 & 4 & 7 & 13 & 6 & 9 & 0 & 0 & \\
\hline UN-Ave & GR & 737 & 728 & 387 & 342 & 184 & 158 & 4 & 7 & 25 & 30 & 41 & 52 & 165 & 186 & $(3046)$ \\
\hline & DR & 331 & 465 & 166 & 229 & 85 & 110 & 2 & 4 & 12 & 19 & 18 & 34 & 71 & 123 & (1669) \\
\hline
\end{tabular}

\section{LODGEPOLE PINE FOREST}

$\begin{array}{lllllllllllllll}\text { SC-1 } & \text { GR } & 368 & 302 & 476 & 403 & 100 & 97 & 2 & 2 & 0 & 0 & 119 & 157 & 415\end{array}$

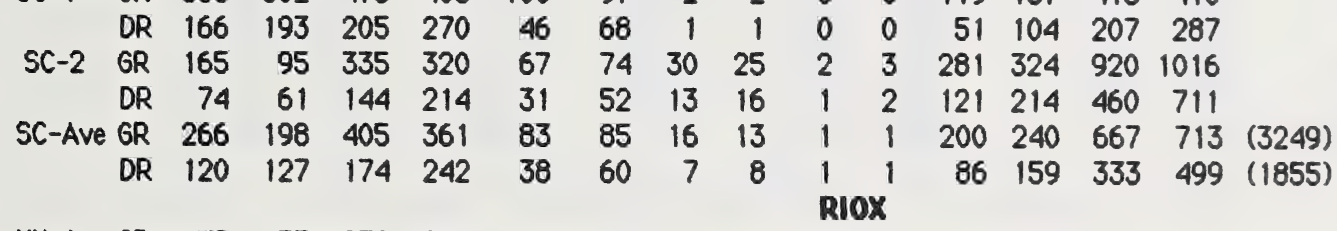

$\begin{array}{llllllllllllllll}U N-1 & G R & 48 & 73 & 270 & 225 & 82 & 90 & 0 & 0 & 62 & 62 & 258 & 268 & 734 & 746\end{array}$ $\begin{array}{lllllllllllllll}\text { DR } & 22 & 47 & 116 & 151 & 38 & 63 & 0 & 0 & 29 & 43 & 111 & 177 & 367 & 522\end{array}$

\section{RUST}

$\begin{array}{llllllllllllllll}\text { UN-2 } & \text { GR } & 320 & 355 & 253 & 271 & 101 & 103 & 15 & 15 & 50 & 45 & 167 & 193 & 1732 & 1922\end{array}$ $\begin{array}{lllllllllllllll}\text { DR } & 144 & 227 & 109 & 182 & 46 & 72 & 7 & 10 & 23 & 31 & 72 & 127 & 866 & 1345\end{array}$

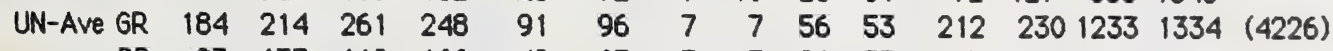

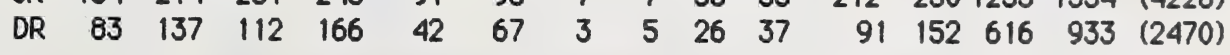

\section{MIXEDWOOD FOREST}

\section{LODI}

$\begin{array}{llllllllll}S C-1 & G R & 22 & 32 & 603 & 561 & 85 & 85 & 49 & 41\end{array}$ $\begin{array}{lllllllll}\text { DR } & 10 & 20 & 259 & 376 & 39 & 60 & 22 & 27\end{array}$

$\begin{array}{llllllllll}\text { UN-2 } & \text { GR } & 0 & 0 & 6 & 7 & 153 & 100 & 23 & 27\end{array}$

(176)

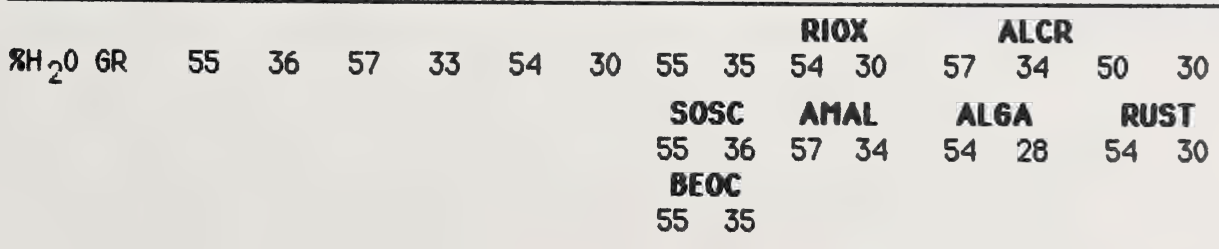

* Results are grams from $20,1 \mathrm{~m}^{2}$ plots $=20 \mathrm{~m}^{2}$ sample. To convert to $\mathrm{kg} / \mathrm{ha}$ multiply by .5 .

* $L=$ Leaves $S=$ stems $\leq .75 \mathrm{~cm}$ diameter. 
Table 2. Woody forage (browse) production and consumption in spruce clear-cuts 5, 17 and 26 years after logging.

\begin{tabular}{lccccc}
\hline & YEARS AFTER L O G G ING \\
Species & Mature & 5 & SC UN & SC UN & SC UN
\end{tabular}

\section{\& Use of Stems ${ }^{1}$}

$\begin{array}{lclllrrrr} & * & * * & & & & & & \\ \text { Poplar } & 37.1 & 0 & 0 & .7 & 4.8 & 5.0 & .7 & 3.0 \\ \text { Rose } & .8 & .8 & 1.1 & 1.8 & 12.8 & 25.2 & 24.9 & 27.8 \\ \text { Willow } & 16.8 & 0 & 1.5 & 2.4 & 6.0 & 12.3 & 11.0 & 9.3 \\ \text { Others } & 12.2 & 6.0 & .4 & 1.5 & 4.1 & 3.2 & 16.6 & 16.4 \\ \text { X Total } & 14.5 & 1.0 & 1.3 & 2.5 & 12.4 & 20.5 & 20.2 & 22.6 \\ \text { Rank } & 4 & 8 & 7 & 6 & 5 & 2 & 3 & 1\end{array}$

\section{Biomass Production (kg/ha)' Green Weight}

\begin{tabular}{lrrrrrrr} 
Poplar & 23.5 & 509.6 & 291.2 & 1419.0 & 1536.6 & 829.0 & 493.0 \\
Rose & 161.3 & 302.4 & 267.7 & 196.0 & 236.3 & 247.0 & 393.0 \\
Willow & 362.8 & 72.8 & 383.0 & 222.9 & 464.8 & 969.0 & 926.0 \\
Others & 44.8 & 78.4 & 54.9 & 68.3 & 28.0 & 30.0 & 26.0 \\
\hline X Total & 592.4 & 963.2 & 996.8 & 1906.2 & 2265.7 & 2074.0 & 1838.0 \\
Rank & 7 & 6 & 5 & 3 & 1 & 2 & 4
\end{tabular}

\section{Total Biomass Used (kg/ha)' in Summer}

\begin{tabular}{lcllcrrrr} 
& $*$ & $* *$ & & & & & & \\
Poplar & 8.6 & 0 & 0 & 2.0 & 68.1 & 76.8 & 5.8 & 14.8 \\
Rose & 1.3 & 1.3 & 3.4 & 4.8 & 25.1 & 59.6 & 61.5 & 109.3 \\
Willow & 60.8 & 0 & 1.1 & 9.2 & 13.3 & 57.2 & 106.6 & 85.7 \\
Others & 5.5 & 2.7 & .3 & .8 & 2.8 & .9 & 4.9 & 4.3 \\
X Total & 76.2 & 4.0 & 4.8 & 16.8 & 109.3 & 194.5 & 178.9 & 214.1 \\
Rank & 5 & 8 & 7 & 6 & 4 & 2 & 3 & 1 \\
\hline
\end{tabular}

* Field surveys conducted five years after nearby clear-cuts had been logged.

* Field surveys conducted 26 years after nearby clear-cuts had been logged.

1 Current year's woody plant growth. 
Table 3. Woody forage (browse) production and consumption in spruce, pine and mixedwood clear-cuts 26 years after logging.

\begin{tabular}{|c|c|c|c|c|c|c|c|c|c|c|c|}
\hline \multirow[t]{2}{*}{ Species } & & $\begin{array}{ll}F & 0 \\
\text { Ice } & \end{array}$ & $R$ & $E$ & S & $\begin{array}{c}T \\
\text { Pine }\end{array}$ & T & Y & $P$ & Mix & \\
\hline & SC & UN & & & $\mathrm{SC}$ & & UN & & & SC & UN \\
\hline
\end{tabular}

\section{Biomass Production' ( $\mathrm{kg} / \mathrm{ha})$}

$\begin{array}{lccccccccc}\text { Poplar } & 829(377) & 493(258) & 389(182) & 46(122) & 749(358) & 202(97) \\ \text { Rose } & 247(110) & 393(163) & 162(64) & 242(117) & 171(89) & 104(72) \\ \text { Willow } & 969(435) & 962(436) & 191(87) & 271(125) & 316(139) & 6(3) \\ \text { Others } & 30(12) & 26(9) & 1316(686) & 1844(916) & 65(24) & 50(18) \\ \text { Total } & 2074(934) & 1838(866) & 2058(1019) & 2403(1195) & 1301(610) & 398(190) \\ \text { Rank } & 3 & 4 & 2 & 1 & 5 & 6\end{array}$

\section{Total Biomass Used 2 ( $\mathrm{kg} / \mathrm{ha})$}

$\begin{array}{lrrrrrrrrrrrr}\text { Poplar } & 6 & (0) & 15 & (0) & 172 & (4) & 30 & (0) & 159 & (0) & 72 & (0) \\ \text { Rose } & 61 & (0) & 109 & (3) & 132 & (5) & 154 & (8) & 25 & (6) & 49 & (6) \\ \text { Willow } & 107 & (0) & 86 & (0) & 99 & (0) & 99 & (3) & 75(39) & 4 & (4) \\ \text { Others } & 5 & (0) & 4 & (3) & 917 & (2) & 1025 & (0) & 20 & (5) & 18(1) \\ \text { Total } & 170 & (0) & 214 & (5) & 1320(11) & 1308 & (11) & 279(50) & 143(11) \\ \text { Rank } & 5 & (6) & 4 & (5) & 1 & (3) & 2 & (4) & 3 & (1) & 6 & (2)\end{array}$

Percent Biomass Used in Summer Plus Winter, and in Summer ( ) Only

$\begin{array}{lrrrlllllllll}\text { Poplar } & 0.7 & (0) & 3.0 & (0) & 44.3 & (0.9) & 38.0 & (0) & 21.3 & (0) & 35.8 & (0) \\ \text { Rose } & 24.9 & (0) & 27.8 & (0.7) & 81.6 & (3.1) & 63.6 & (3.2) & 14.9 & (3.4) & 35.3 & (4.0) \\ \text { Willow } & 11.0 & (0) & 9.3 & (0) & 51.7 & (0) & 36.4 & (1.0) & 23.9 & (18.4) & 70.0 & (2.9) \\ \text { Others } & 16.6 & (0) & 16.4 & (9.3) & 48.6 & (0.2) & 43.2 & (0) & 31.3 & (6.8) & 40.1 & (2.5) \\ \text { Total } & 20.2 & (0) & 22.6 & (0.6) & 69.7 & (0.5) & 55.6 & (0.4) & 20.0 & (3.7) & 36.1 & (2.8)\end{array}$

Current years growth of leaves and twigs combined; green and dry () weights up to $2.4 \mathrm{~m}(8.0$ ft.) above ground.

2 Biomass used is summer plus winter use from visual use of all plots and summer only ( ) use derived from clip plot data. 
Avifauna Sightings in Clear-cuts and Mature Forests 
Table 1. Grouse observed in 32 year-old clear-cuts, June-August, 1988.

\begin{tabular}{|c|c|c|c|c|c|c|c|}
\hline MONTH & GROUSE & $M I X E$ & OOD & P I & $E$ & $S P R$ & $C E$ \\
\hline & SPECIES & SCAR. & UNSC. & SCAR. & UNSC. & SCAR. & UNSC. \\
\hline JUNE & Ruffed & & & & & $\begin{array}{l}2 \text { female } \\
\text { with } \\
\text { broods }\end{array}$ & \\
\hline & Spruce & & & 1 & & & \\
\hline JULY & Ruffed & 1 & 1 & & & & \\
\hline & Spruce & & & & $\begin{array}{l}\text { female } \\
\text { with } 7 \\
\text { chicks }\end{array}$ & & \\
\hline AUGUST & Ruffed & & & & & $\begin{array}{l}\text { female } \\
\text { with } 6 \\
\text { jov. }\end{array}$ & \\
\hline & Spruce & & & 2,4 & & & \\
\hline OCTOBER & Ruffed & & 1 & & & & \\
\hline & Spruce & $\begin{array}{l}1 \text { also } \\
\text { in matu }\end{array}$ & 1 & & & & \\
\hline Totals & $\begin{array}{l}\text { Ruffed } \\
\text { Spruce }\end{array}$ & $\begin{array}{l}1 \\
0\end{array}$ & $\begin{array}{l}2 \\
1\end{array}$ & $\begin{array}{l}0 \\
7\end{array}$ & $\begin{array}{l}0 \\
8\end{array}$ & $\begin{array}{l}3 \text { broods } \\
0\end{array}$ & $\begin{array}{l}\text { none } \\
0\end{array}$ \\
\hline
\end{tabular}


Table 2. Abundance of birds in mature and 32 year old cleat-cuts of three forest types, summer 1988.

GRCOUF \& SPECIES
WHITE SPRUCE LODGEFOLE PINE

Unsc. Scar. Mature Total Unsc. Scar. Mature Total Unsc. Scar. Mature Total

\section{Flycatchers}

\begin{tabular}{|c|c|c|c|c|c|c|c|c|c|c|c|c|}
\hline Traill's & 0 & 6 & 0 & 6 & 0 & 2 & - & 2 & 0 & 1 & 0 & 1 \\
\hline others & 2 & 0 & 0 & 2 & 0 & 3 & - & 3 & 0 & 2 & 0 & 2 \\
\hline \multicolumn{13}{|l|}{ Chickadees } \\
\hline Black-capped & 4 & 0 & 0 & 4 & 6 & 2 & - & 8 & 8 & 1 & 0 & 9 \\
\hline Boreal & 0 & 0 & 0 & 0 & 6 & 0 & - & 6 & 0 & 0 & 0 & 0 \\
\hline \multicolumn{13}{|l|}{ Thrushes } \\
\hline Robin & 12 & 32 & 0 & 44 & 1 & 0 & - & 1 & 9 & 8 & 1 & 18 \\
\hline Hermit & 2 & 0 & 0 & 2 & 14 & 13 & - & 27 & 14 & 16 & 0 & 30 \\
\hline others & 2 & 2 & 0 & 4 & 15 & 5 & - & 20 & 2 & 5 & 0 & 7 \\
\hline \multicolumn{13}{|l|}{ Warblers } \\
\hline Yellow-rumped & 11 & 0 & 0 & 11 & 4 & 3 & - & 7 & 19 & 1 & 2 & 22 \\
\hline Or ange-crowned & 0 & 3 & 0 & 3 & 6 & 2 & - & 8 & 1 & 0 & 0 & 1 \\
\hline athers & 1 & 1 & 1 & 3 & 10 & 4 & - & 14 & 0 & 1 & 1 & 2 \\
\hline \multicolumn{13}{|l|}{ Yireos } \\
\hline $\begin{array}{l}\text { Warbling } \\
\text { Yaxwings }\end{array}$ & \multicolumn{12}{|c|}{ Yaxwings } \\
\hline Cedar & 0 & 12 & 0 & 12 & 0 & 0 & - & 0 & 0 & 0 & 0 & 0 \\
\hline \multicolumn{13}{|l|}{ Ravens } \\
\hline Common & 1 & 0 & 0 & 1 & 3 & 1 & - & 4 & 6 & 1 & 1 & 8 \\
\hline \multicolumn{13}{|l|}{ Sparrows } \\
\hline All & 7 & 9 & 0 & 16 & 4 & 1 & - & 5 & 43 & 9 & 2 & 54 \\
\hline \multicolumn{12}{|l|}{ Siskins } & \\
\hline $\begin{array}{l}\text { Pine } \\
\text { Junces }\end{array}$ & 0 & 5 & 0 & 5 & 4 & 0 & - & 4 & 24 & 4 & 1 & 29 \\
\hline Dark-eyed & 7 & 6 & 1 & 14 & 6 & 5 & - & 11 & 16 & 5 & 1 & 22 \\
\hline \multicolumn{12}{|l|}{ Nuthatches } & \\
\hline \multirow{2}{*}{\multicolumn{12}{|c|}{ Kinglets }} & 11 \\
\hline & & & & & & & & & & & & \\
\hline Golden\&Ruby-crowned & & 1 & 0 & 2 & 8 & 3 & - & 11 & 2 & 0 & 0 & 2 \\
\hline \multicolumn{12}{|l|}{ Finches } & \\
\hline $\begin{array}{l}\text { Purple } \\
\text { Crossbills }\end{array}$ & 0 & 0 & 0 & 0 & 0 & 0 & - & 0 & 1 & 0 & 0 & 1 \\
\hline \multicolumn{12}{|l|}{ Jays } & 4 \\
\hline Gray & 5 & 2 & 6 & 13 & 20 & 2 & - & 22 & 1 & 0 & 0 & 1 \\
\hline \multicolumn{12}{|l|}{ Yoodpecker } & \\
\hline Flicker & 3 & 1 & 0 & 4 & 6 & 0 & - & 6 & 14 & 6 & 3 & 23 \\
\hline
\end{tabular}




\begin{tabular}{|c|c|c|c|c|c|c|c|c|c|c|c|c|}
\hline Ruffed & 0 & 8 & 0 & 8 & 0 & 7 & - & 7 & 7 & 0 & 0 & 7 \\
\hline $\begin{array}{l}\text { Spruce } \\
\text { Hayks }\end{array}$ & 0 & 0 & 0 & 0 & 23 & 2 & - & 25 & 1 & 0 & 1 & 2 \\
\hline Kestrel & 0 & 0 & 0 & 0 & 1 & 0 & - & 1 & 0 & 0 & 0 & 0 \\
\hline Merlin & 0 & 0 & 0 & 0 & 0 & 0 & - & 0 & 0 & 0 & 1 & 1 \\
\hline Goshawk & 0 & 0 & 0 & 0 & 1 & 0 & - & 1 & 0 & 0 & 0 & 0 \\
\hline $\begin{array}{l}\text { Others } \\
\text { Bluebird }\end{array}$ & 0 & 0 & 0 & 0 & 0 & 0 & - & 0 & 0 & 1 & 0 & 1 \\
\hline $\begin{array}{l}\text { Mountain } \\
\text { Swallows }\end{array}$ & 2 & 0 & 0 & 2 & 0 & 0 & - & 0 & 0 & 0 & 0 & 0 \\
\hline $\begin{array}{l}\text { Tree } \\
\text { Starling }\end{array}$ & 0 & 0 & 0 & 0 & 0 & 0 & - & 0 & 0 & 1 & 0 & 1 \\
\hline $\begin{array}{l}\text { European } \\
\text { other birds }\end{array}$ & 0 & 0 & 0 & 0 & 0 & 0 & - & 0 & 3 & 0 & 0 & 3 \\
\hline All & 22 & 4 & 0 & 26 & 10 & 1 & - & 11 & 4 & 1 & 0 & 5 \\
\hline $\begin{array}{l}\text { Total Birds } \\
\text { Observation Hrs. }\end{array}$ & $\begin{array}{l}83 \\
30.5\end{array}$ & $\begin{array}{l}94 \\
28.5\end{array}$ & $\begin{array}{l}10 \\
10.5\end{array}$ & $\begin{array}{l}187 \\
69.5\end{array}$ & $\begin{array}{l}156 \\
40.0\end{array}$ & $\begin{array}{l}63 \\
39.0\end{array}$ & - & $\begin{array}{r}219 \\
79\end{array}$ & $\begin{array}{l}183 \\
32.5\end{array}$ & $\begin{array}{l}65 \\
27.5\end{array}$ & $\begin{array}{l}20 \\
13.7\end{array}$ & $\begin{array}{l}268 \\
73.7\end{array}$ \\
\hline - Per Hour & 2.7 & 3.3 & 1.0 & 2.7 & 3.9 & 1.6 & - & 2.8 & 5.6 & 2.4 & 1.5 & 3.6 \\
\hline Species & 12 & 18 & 4 & 25 & 25 & 17 & - & 26 & 22 & 19 & 12 & 30 \\
\hline
\end{tabular}


Table 3 Abundence of avifauna during two successional stages following logging in three forest types.

\begin{tabular}{|c|c|c|c|c|c|c|}
\hline \multirow[t]{2}{*}{ Species } & WHLIE & SPRUCE & LODGEPOLE & E PINE & $M \perp x \in D$ & $D W 000$ \\
\hline & $\begin{array}{c}\text { Scarifled } \\
1-15=16-27\end{array}$ & $\begin{array}{l}\text { Unscarifled } \\
1-15 \text { 16-27 }\end{array}$ & $\begin{array}{c}\text { Scarifled } \\
1-1516-27\end{array}$ & $\begin{array}{l}\text { Unscarified } \\
1-1516-27\end{array}$ & $\begin{array}{l}\text { Scarified } \\
1-15 \quad 16-27\end{array}$ & $\begin{array}{l}\text { Unscarifled } \\
1-15 \quad 16-27\end{array}$ \\
\hline
\end{tabular}

\section{Hawts end Falcees (Accipitrides)}

\begin{tabular}{|c|c|c|c|c|c|c|c|c|c|c|c|}
\hline Sharp-shinned & - & 0 & - & 0 & - & 0 & - & 0 & - & 0 & - \\
\hline Northern Goshawk & - & 0 & - & 0 & - & 0 & - & 0 & - & 0 & - \\
\hline Swainson's & - & 1 & - & 0 & - & 0 & - & 0 & - & 0 & - \\
\hline Americen kestrol & - & 0 & - & 0 & - & 0 & - & 0 & - & 6 & - \\
\hline Merlin & - & 0 & - & 0 & - & 0 & - & 0 & - & 0 & - \\
\hline Totals & - & 1 & - & 0 & - & 0 & - & 0 & - & 6 & 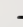 \\
\hline
\end{tabular}

\section{Greese (Phasienideo)}

$\begin{array}{lrrrrrrrrrrrr}\text { Spruce } & 0 & 1 & 0 & 1 & 0 & 0 & 0 & 1 & 0 & 0 & 0 & 4 \\ \text { Blue } & 7 & 3 & 0 & 0 & 0 & 0 & 0 & 0 & 0 & 0 & 0 & 0 \\ \text { Ruffed } & 0 & 9 & 0 & 2 & 0 & 2 & 0 & 0 & 0 & 20 & 8 & 10 \\ \text { Sherp-talled } & 0 & 0 & 0 & 0 & 3 & 0 & 0 & 0 & 0 & 0 & 0 & 1 \\ \text { Totals } & 7 & 13 & 0 & 3 & 3 & 2 & 0 & 1 & 0 & 20 & 8 & 14\end{array}$

\section{Woedpockers (Piciden)}

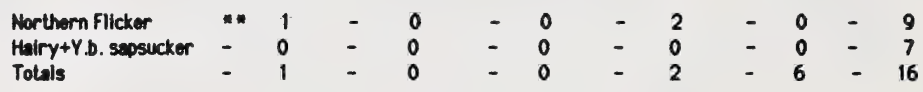

\section{Chickedoes (Peridso)}

BI. capped \& Boreal - $2-0-2-2$ - 02

Thrushes (Muscicapldes) and Warblers (Emberizldes)

$\begin{array}{lllllllllllll}\text { Hermit thrush } & 0 & 1 & 0 & 0 & 0 & 0 & 0 & 1 & 0 & 0 & 0 & 0 \\ \text { American Robin } & - & 1 & - & 1 & - & 1 & - & 2 & - & 0 & - & 5 \\ \text { Werblers } & - & 1 & - & 1 & - & 7 & - & 1 & - & 0 & - & 7 \\ \text { Totals } & - & 3 & - & 2 & - & 6 & - & 4 & - & 0 & - & 16\end{array}$

unces. Sperrours, Stetiss (Emberiziles)

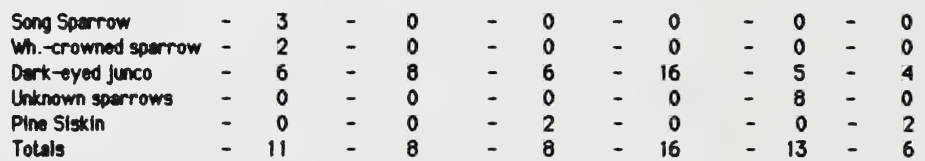

Others

$\begin{array}{lllllllllllll}\text { Gray jay } & - & 0 & - & 2 & - & 4 & - & 2 & - & 0 & - & 4 \\ \text { Common nighthawk } & 0 & 2 & 0 & 0 & 0 & 0 & 0 & 0 & 0 & 3 & 1 & 1 \\ \text { Hummingbird } & 1 & 0 & 0 & 0 & 0 & 0 & 0 & 0 & 0 & 0 & 0 & 0 \\ \text { Codar waxwing } & 0 & 0 & 0 & 4 & 0 & 0 & 0 & 0 & 0 & 0 & 0 & 2 \\ \text { Rad-breasted muthatch } & 0 & 1 & 0 & 0 & 0 & 0 & 0 & 1 & 0 & 0 & 0 & 0 \\ \text { Vireos } & - & 0 & - & 0 & - & 3 & - & 0 & - & 0 & - & 0 \\ \text { Common snipe } & 0 & 0 & 0 & 1 & 0 & 0 & 0 & 1 & 0 & 0 & 0 & 0 \\ \text { Uplend sandplper } & 0 & 0 & 0 & 2 & 0 & 0 & 0 & 0 & 0 & 0 & 0 & 0 \\ \text { Starling } & 0 & 0 & 0 & 0 & 0 & 0 & 0 & 0 & 0 & 0 & 0 & 1 \\ \text { Totals } & 1 & 3 & 0 & 9 & 0 & 7 & 0 & 4 & 0 & 3 & 1 & 8 \\ \text { Grand totals } & 8 & 34 & 0 & 22 & 3 & 27 & 0 & 27 & 0 & 44 & 9 & 92\end{array}$

- Years 1-15 (Grass-forb and Shrub-seedling stage) and Years 16-27 (Pole-sapling) stage.

- No data. These were species not recorded during Years 1-15. 
Appendix 11

Density of Tree Snags and Use by Wildlife

Year 32 (1988) 
Table 1a. Density of snags with cavities.

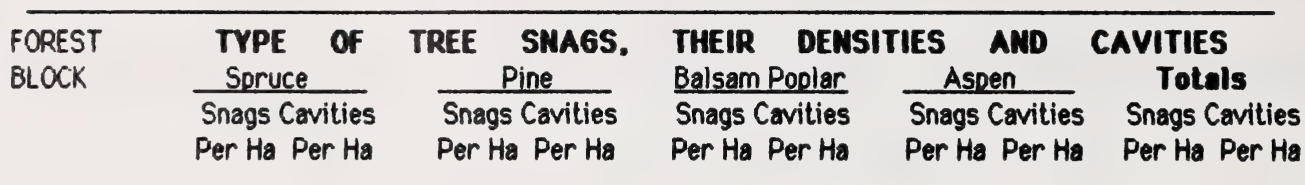

\section{MIXEDWOOD FOREST}

$\begin{array}{lrrrrrrrrrr}\mathrm{SC}^{1} & 0 & - & 0 & - & 0 & - & 0 & - & 0 & - \\ \mathrm{UN}^{-1} & 0 & - & 14 & 2 & 0 & - & 10 & 10 & 24 & 12 \\ -2 & 4 & 4 & 4 & 6 & 2 & 4 & 12 & 8 & 22 & 22 \\ \text { AVE.UN }^{1} & 2 & 2 & 9 & 4 & 1 & 2 & 11 & 9 & 23 & 17 \\ \text { MATURE }^{1} & 24 & 4 & 18 & 10 & 0 & 0 & 34 & 0 & 76 & 14\end{array}$

\section{LODGEPOLE PINE FOREST}

$\begin{array}{cllllllllll}\text { SC - 1 } & 0 & - & 0 & - & 0 & - & 0 & - & 0 & - \\ -2 & 0 & - & 6 & 2 & 24 & 0 & 0 & - & 30 & 2 \\ \text { AVE.SC } & 0 & - & 3 & 1 & 12 & 0 & 0 & - & 15 & 1 \\ -1 & 0 & - & 32 & 8 & 0 & - & 0 & - & 32 & 8 \\ -2 & 0 & - & 54 & 6 & 0 & - & 0 & - & 54 & 6 \\ \text { AVE.UN } & 0 & - & 43 & 7 & 0 & - & 0 & - & 43 & 7\end{array}$

\section{WHITE SPRUCE FOREST}

$\begin{array}{ccccccccccc}\text { SC - } 1 & 0 & - & 0 & - & 0 & - & 0 & - & 0 & - \\ -2 & 0 & - & 0 & - & 0 & - & 0 & - & 0 & - \\ \text { AVE. SC } & 0 & - & 0 & - & 0 & - & 0 & - & 0 & - \\ \text { UN - } & 30 & 8 & 0 & - & 2 & 0 & 0 & - & 32 & 8 \\ -2 & 10 & 6 & 0 & - & 2 & 0 & 0 & - & 12 & 6 \\ \text { AVE. UN } & 20 & 7 & 0 & - & 2 & 0 & 0 & - & 22 & 7 \\ \text { MATURE } & 42 & 24 & 0 & - & 6 & 0 & 0 & - & 48 & 24\end{array}$

$1_{S C}=$ Scarified, $U N=$ Scarified clear-cuts, Mature $=$ Unlogged forest. 
Table 1b. Density of tree snags of various diameters.

\begin{tabular}{lcccccc}
\hline TOTAL & S N A G & D I A M E E T E R & (CM) \\
SNAGS & $15-30$ & $31-35$ & & $36-50$ & $51+$ \\
\hline
\end{tabular}

\section{MIXEDWOOD FOREST}

$\begin{array}{cccccc}\text { SC' }^{\prime} & 0 & 0 & 0 & 0 & 0 \\ \text { UN }^{-1} & 24 & 14 & 2 & 8 & 0 \\ -2 & 22 & 8 & 6 & 8 & 0 \\ \text { AVE. UN }^{\prime} & 24 & 12 & 4 & 8 & 0 \\ \text { MATURE }^{1} & 76 & 68 & 8 & 0 & 0\end{array}$

\section{LODGEPOLE PINE FOREST}

$\begin{array}{cccccc}\text { SC - 1 } & 0 & 0 & 0 & 0 & 0 \\ -2 & 30 & 24 & 4 & 2 & 0 \\ \text { AVE. SC } & 16 & 12 & 2 & 2 & 0 \\ \text { UN - 1 } & 32 & 20 & 8 & 4 & 0 \\ -2 & 54 & 42 & 8 & 4 & 0 \\ \text { AVE. UN } & 44 & 32 & 8 & 4 & 0\end{array}$

\section{WHITE SPRUCE FOREST}

$\begin{array}{cccccc}\text { SC - 1 } & 0 & 0 & 0 & 0 & 0 \\ -2 & 0 & 0 & 0 & 0 & 0 \\ \text { AVE. SC } & 0 & 0 & 0 & 0 & 0 \\ \text { UN - 1 } & 32 & 28 & 2 & 0 & 0 \\ -2 & 12 & 10 & 2 & 0 & 0 \\ \text { AVE. UN } & 24 & 20 & 2 & 0 & 1 \\ \text { MATURE } & 48 & 38 & 8 & 0 & 0\end{array}$

1 SC = Scarified, UN = Scarified clear -cuts, Mature = Unlogged forest. 
Appendix 12

Glossary of Terms 
Abundance - Relative abundance of one wildlife species over time or of one species to another. Abundance based on one or more of the following direct and indirect census indices: faecal pellet group density, sets of tracks per unit area, beds, nests, cavities, cursury observations, aerial/ground counts. Does not refer to actual animal numbers per unit area (see Density).

Big Game - Moose, elk (wapiti), mule and white-tailed deer. See Cervids.

Biomass (browse) - The weight (green or dry) of woody plant forage up to $2.4(8 \mathrm{ft})$ above ground.

Browse - That part of leaf and twig growth of shrubs, woody vines and trees available for animal consumption and known to be used as food by the animal discussed.

Canopy Cover - The vertical projection downward of the aerial portion of shrubs and trees, expressed as percent of ground occupled.

Carrying Capacity (Range Carrying Capacity) - The maximum stocking rate possible without inducing damage to vegetation or related resources.

Cervids - Big game of the deer family. For this study they are moose, elk, white-talled and mule deer.

Cover - Sheiter and security for birds and mammals. Shelter cover refers to thermal cover (protection against wind chill in winter or excessive heat in summer). Security cover refers to escape or hiding cover and is inversely related to visibility.

Degree of Use - The proportion of current year's forage production that is consumed and/or destroyed by grazing animals.

Density - The number of individuals per unit area.

Diet - A function of coverage and degree of utilization. For grasses (graminoids) and forbs in this study, it refers to average use within plots times coverage. Obtained by multiplying \% coverage $x$ use and then dividing by the total use value of all forbs or grasses.

Exposure - Direction of slope with respect to points of a compass.

Fauna - The animal life of the region.

Flora - The plant species of an area.

Forb - Any herbaceous plant other than graminoids (grass, sedge, rush). Those herbaceous plants commonly referred to as wild flowers.

Grass - Refers to members of the true grassses (Gramineae) plus grasslike (Cyperaceae and Juncaceae) plants. 
Habitat - The natural abode of an animal, including all-biotic, climatic, and edalphic factors affecting life. In this study habitat was assessed on the basis of vegetation and its ability to provide suitable cover.

Herbaceous - Combined forb and grass cover or biomass.

Native Species - A species which is part of the original fauna or flora of the area in question.

Numbers - Values based on quantative numbers observed. If values are counts per unit area then numbers are synonymous with density.

Palatability - The relish with which a plant species is consumed by an animal.

Plant Succession - See Succession.

Preference (Grazing Preference) - Selection of certain plants over others by grazing animals.

Preferred Species - Species preferred by animals and grazed by first choice.

Range Carrying Capacity - See Carrying Capacity.

Species Composition - The proportions of various plant species in relation to the total of a given area; expressed as cover, density, weight etc.

Stocking Rate (Stocking Density) - The relationship between number of animals and area of land at any instant of time.

Succession - The process of vegetational development whereby an area becomes successively occupied by different plant communites of higher ecological order.

Use - $\quad$ See Degree of Use.

Utilization - See Degree of Use. 


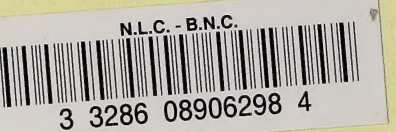

